\title{
Alaska Division of Geological \&e Geophysical Surveys Annual Report 2009
}

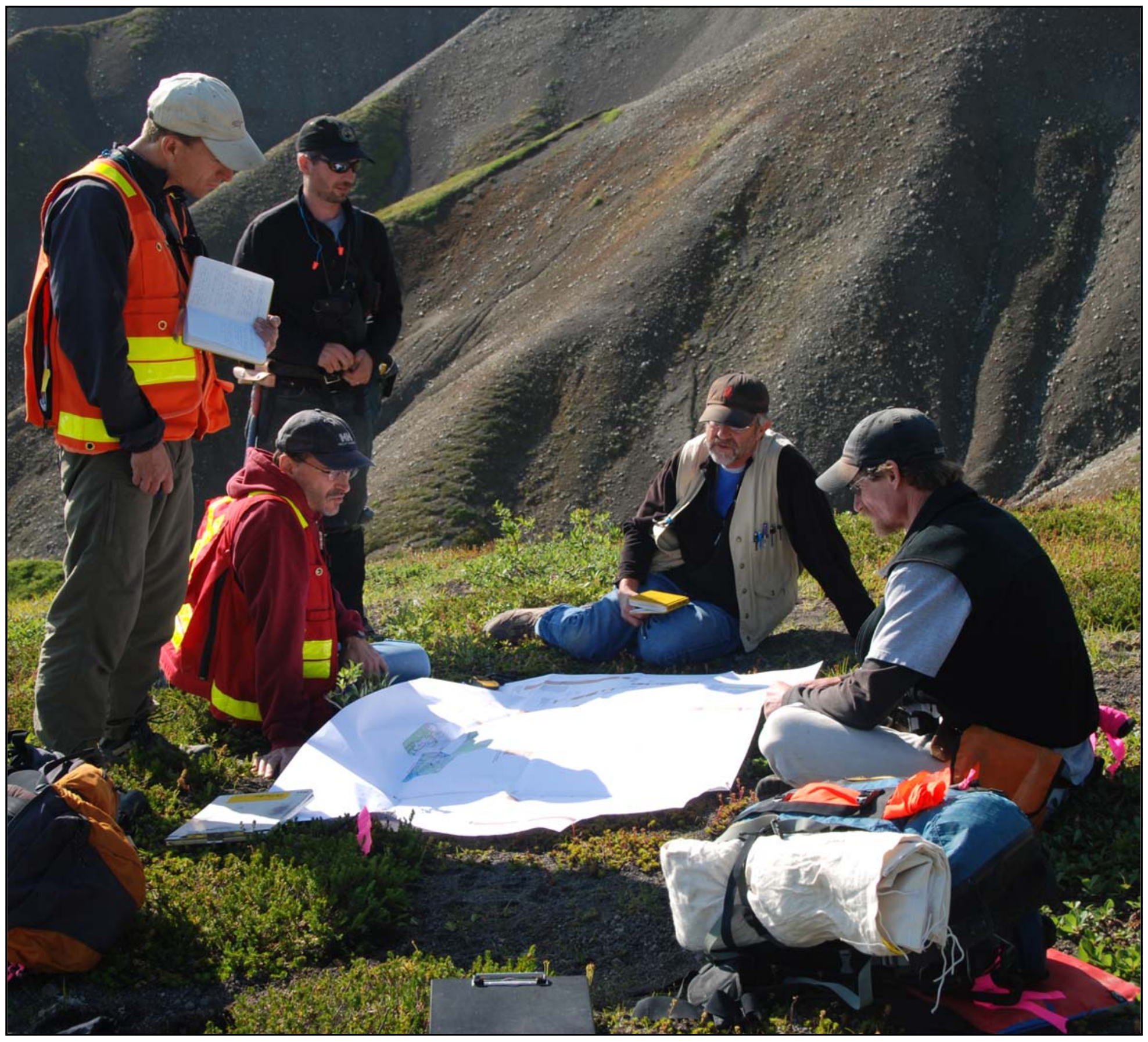





\section{Alaska Division of Geological \& GeOPHySiCAl SuRVeys ANNUAL RePORT 2009}

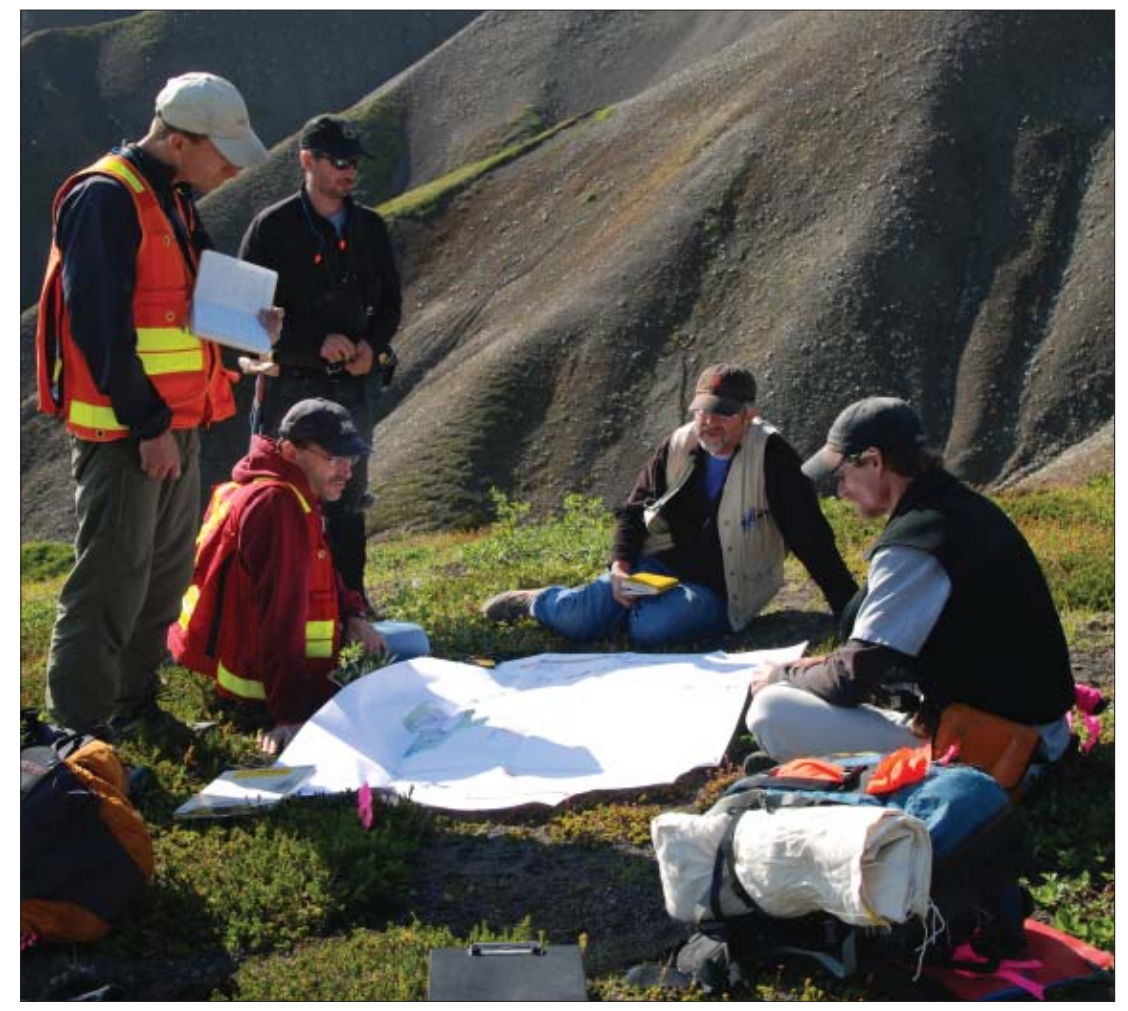

Front cover: Geologists Paul Decker (DOG), Marwan Wartes (DGGS), Dave LePain (DGGS), Rick Stanley (USGS), and Bob Gillis (DGGS) discuss stratigraphic relationships in the West Foreland Formation in northwestern Cook Inlet. Recent geologic studies in the Capps Glacier area yield insight into the structural history of the northwestern basin margin and the sedimentologic architecture of oil and gas reservoir rocks in the Tertiary basin fill. Ongoing multi-agency research in Cook Inlet is led by DGGS, whose goal is to provide timely, publicly available geologic information to the community, industry, and public policy makers at a time when potential gas production and delivery shortfalls are of rising concern in south-central Alaska. Photo by Trystan Herriott.

State of Alaska

Department of Natural Resources

Division of Geological \& Geophysical Surveys 


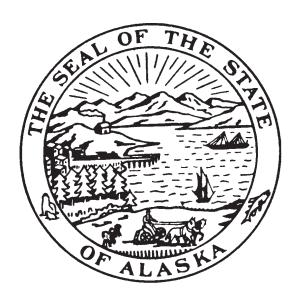

STATE OF ALASKA

Sean Parnell, Governor

DEPARTMENT OF NATURAL RESOURCES

Tom Irwin, Commissioner

\section{DIVISION OF GEOLOGICAL \& GEOPHYSICAL SURVEYS Rodney A. Combellick, Acting Director}

Division of Geological \& Geophysical Surveys publications can be inspected on the web at http://www.dggs.dnr.state.ak.us/ or at the following locations.

Address mail orders to the Fairbanks office.

Alaska Division of Geological

\& Geophysical Surveys

3354 College Road

Fairbanks, Alaska 99709-3707

Elmer E. Rasmuson Library

University of Alaska Fairbanks

Fairbanks, Alaska 99775-1005
University of Alaska Anchorage Library 3211 Providence Drive Anchorage, Alaska 99508

Alaska Resource Library

3150 C Street, Suite 100

Anchorage, Alaska 99503

\footnotetext{
Alaska State Library

State Office Building, 8th Floor

333 Willoughby Avenue

Juneau, Alaska 99811-0571
}

Publication of this report is required by Alaska Statute 41.08 .

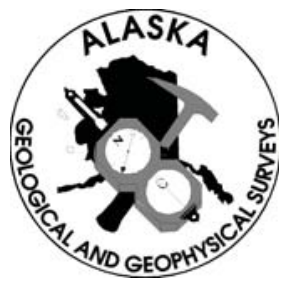




\section{Contents}

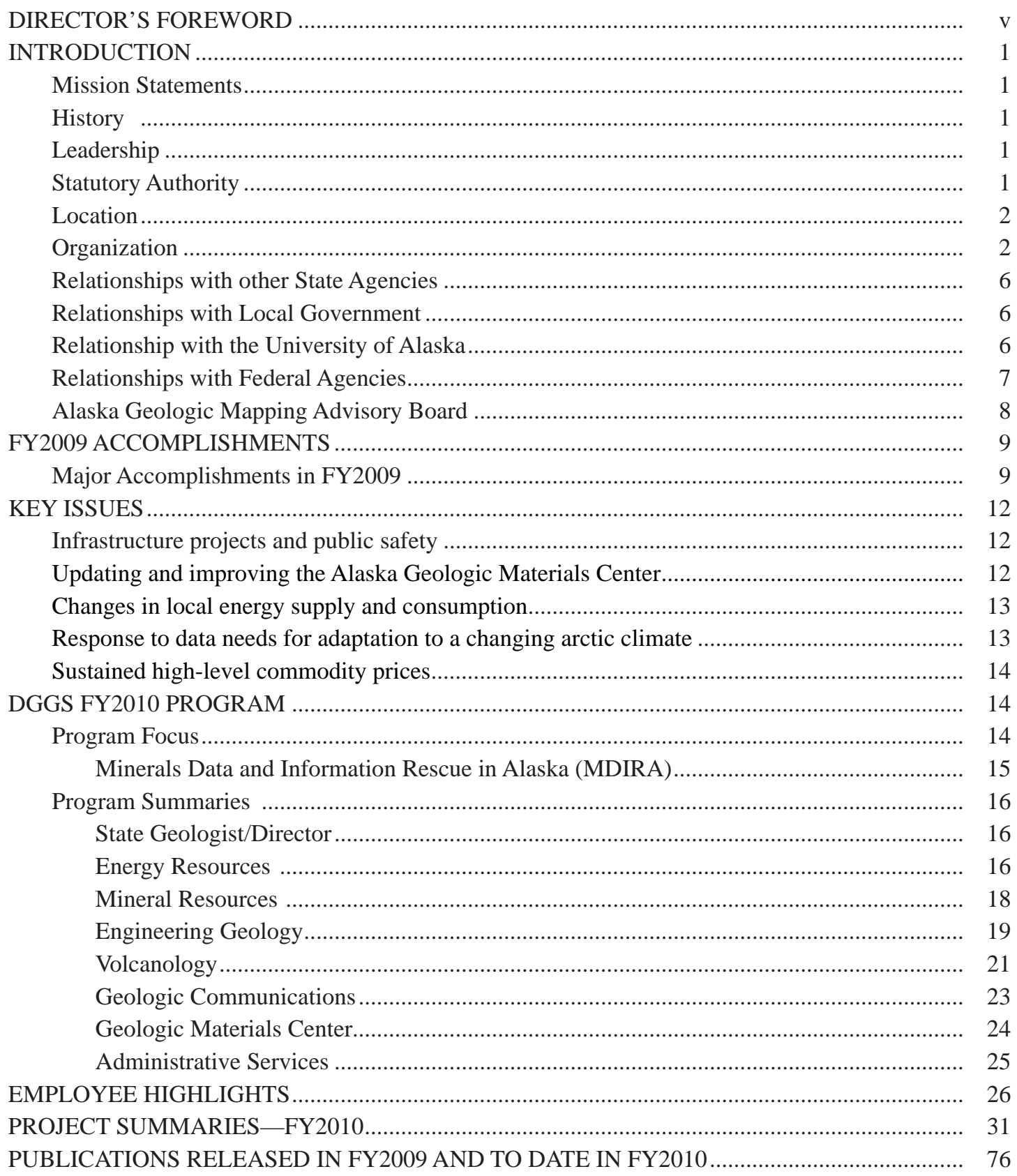

\section{FIGURE}

DGGS ORGANIZATIONAL CHART 



\section{Director's Foreword}

The world is changing rapidly, and our DGGS world is no exception. As you will read in the following pages, the Alaska Division of Geological \& Geophysical Surveys is responding enthusiastically to increasing demands for geologic information needed to assess Alaska's energy- and mineral-resource potential, climate-change-related impacts in coastal areas, hazards to existing and proposed infrastructure, and volcanic activity, to name just a few. As you will also see, DGGS is undergoing some changes in staff, partly in response to these demands and partly as a result of retirements. Several more of our employees are nearing retirement age, so we expect this is just the beginning. Because other organizations, public and private, are responding to similar demands in their sectors, we are also facing the challenge of recruiting and retaining well-trained professionals from a limited pool of qualified candidates. Fortunately, many potential recruits see Alaska as we do, as a geologist's candy store, and are excited to join our team. As we say goodbye and thank you to geologists John Reeder and Rocky Reifenstuhl for their many years of dedicated service, we welcome Trystan Herriott, Richard Koehler, Gabriel Wolken, and Brent Elliott to the fold, as well as returning geologist Ken Papp. Profiles of these outstanding professionals are included under Employee Highlights.

Not one to shy away from a challenge when he believes he can make a positive impact, State Geologist Bob Swenson responded to a call from Governor Sean Parnell for a temporary assignment to coordinate efforts to facilitate delivery of affordable natural gas to in-state customers. In this capacity, Bob is working in parallel with

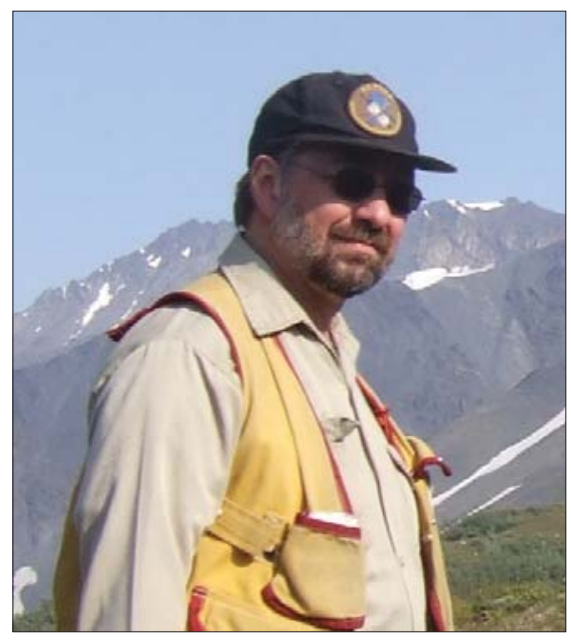
the Alaska Natural Gas Development Authority, and former Division of Oil \& Gas and U.S. Geological Survey director Mark Myers, who is coordinating development of a large-diameter pipeline to export North Slope natural gas to markets in North America and elsewhere. Bob agreed to accept this assignment on a temporary basis until October 2010, when he expects to put his DGGS hat back on and return full time to his position as state geologist. In the meantime, I am honored to again serve as acting director.

I hope you enjoy reading about the activities and accomplishments of your state geological survey. Please feel free to email or call me at any time.

Rod Combellick, Acting Director, Division of Geological \& Geophysical Surveys 



\section{Division of Geological \& Geophysical Surveys ANNUAL REPORT 2009}

\section{INTRODUCTION}

MISSION STATEMENTS

Department of Natural Resources

Mission: Develop, conserve, and enhance natural resources for present and future Alaskans

Division of Geological \& Geophysical SuRveys

Mission: Determine the potential of Alaskan land for production of metals, minerals, fuels, and geothermal resources, the locations and supplies of groundwater and construction material; and the potential geologic hazards to buildings, roads, bridges, and other installations and structures (AS 41.08.020)

\section{HISTORY}

The present Division of Geological \& Geophysical Surveys (DGGS) evolved from Alaska's Territorial Department of Mines. That heritage is reflected in the Division's ongoing commitment to the application of geology to improve the welfare of Alaska citizens. The current name and mission of the Division were established in 1972 with the passage of Alaska Statute AS 41.08.

Territorial Department of Mines, 1959

Division of Mines and Minerals, 1959-1966

Division of Mines and Geology, 1966-1970

Division of Geological Survey, 1970-1972

Division of Geological \& Geophysical Surveys, 1972-Present

\section{LEADERSHIP}

Ten qualified professional geoscientists have served as State Geologist:

Jim Williams, 1959-1971

William Fackler, 1971-1973

Donald Hartman, 1973-1975

Ross G. Schaff, 1975-1986

Robert B. Forbes, 1987-1990

Thomas E. Smith, 1991-1995

Milton A. Wiltse, 1995-2002

Rodney A. Combellick, 2003-January 2005

Mark D. Myers, February-October 2005

Robert F. Swenson, November 2005-present

By statute the State Geologist serves as the Director of the Division of Geological \& Geophysical Surveys in the Department of Natural Resources (DNR) and is appointed by the DNR Commissioner. Since the early 1970s, the State Geologists have been selected from lists of candidates prepared by the geologic community and professional societies within Alaska. A department order in 2002 formalized a process whereby the Geologic Mapping Advisory Board oversees evaluation of candidates and provides a list to the Commissioner. The qualifications and responsibilities of the State Geologist and the mission of DGGS are defined by statute.

\section{STATUTORY AUTHORITY}

Alaska Statutes Sec. 41.08.010. Division of geological and geophysical surveys. There is established in the Department of Natural Resources a Division of geological and geophysical surveys under the direction of the state geologist. (1 ch 93 SLA 1972)

Sec. 41.08.015. State geologist. The commissioner of natural resources shall appoint the state geologist, who must be qualified by education and experience to direct the activities of the Division. (1 ch 93 SLA 1972)

Sec. 41.08.020. Powers and duties. (a) The state geologist shall conduct geological and geophysical surveys to determine the potential of Alaskan land for production of metals, minerals, fuels, and geothermal resources; the locations and supplies of groundwater and construction materials; the potential geologic hazards to buildings, roads, bridges and other installations and structures; and shall conduct such other surveys and investigations as will advance knowledge of the geology of Alaska. With the approval of the commissioner, the state geologist may acquire, by gift or purchase, geological and geophysical reports, surveys and similar information.

Sec. 41.08.030. Printing and distribution of reports. The state geologist shall print and publish an annual report and such other special and topical reports and maps as may be desirable for the benefit of the State, including the printing or reprinting of reports and maps made by other persons or agencies, where authorization to do so is obtained. Reports and maps may be sold and all money received from these sales shall be paid into the general fund. ( $\$$ I ch 93 SLA 1972) 


\section{LOCATION}

The Division's administrative headquarters and personnel moved to Fairbanks in 1987. The close proximity of the Division to the earth science research laboratories of the University of Alaska Fairbanks campus has a strategic benefit to the DGGS program. University staff and students are important adjunct members of many DGGS project teams.

Current DGGS staff totals 36 permanent full-time professional and support personnel, a Director, Deputy Director, and five student interns.

DGGS operates the Alaska Geologic Materials Center in Eagle River, Alaska, staffed by three professional geologists and four student interns. DGGS also administers the 11-member Alaska Seismic Hazards Safety Commission.

\section{ORGANIZATION}

DGGS is one of eight divisions and five offices in the Alaska Department of Natural Resources. Under the overall administration of the Director's Office, the Division of Geological \& Geophysical Surveys is organized into five sections and the Geologic Materials Center (fig. 1). The Division also administers the Alaska Seismic Hazards Safety Commission.
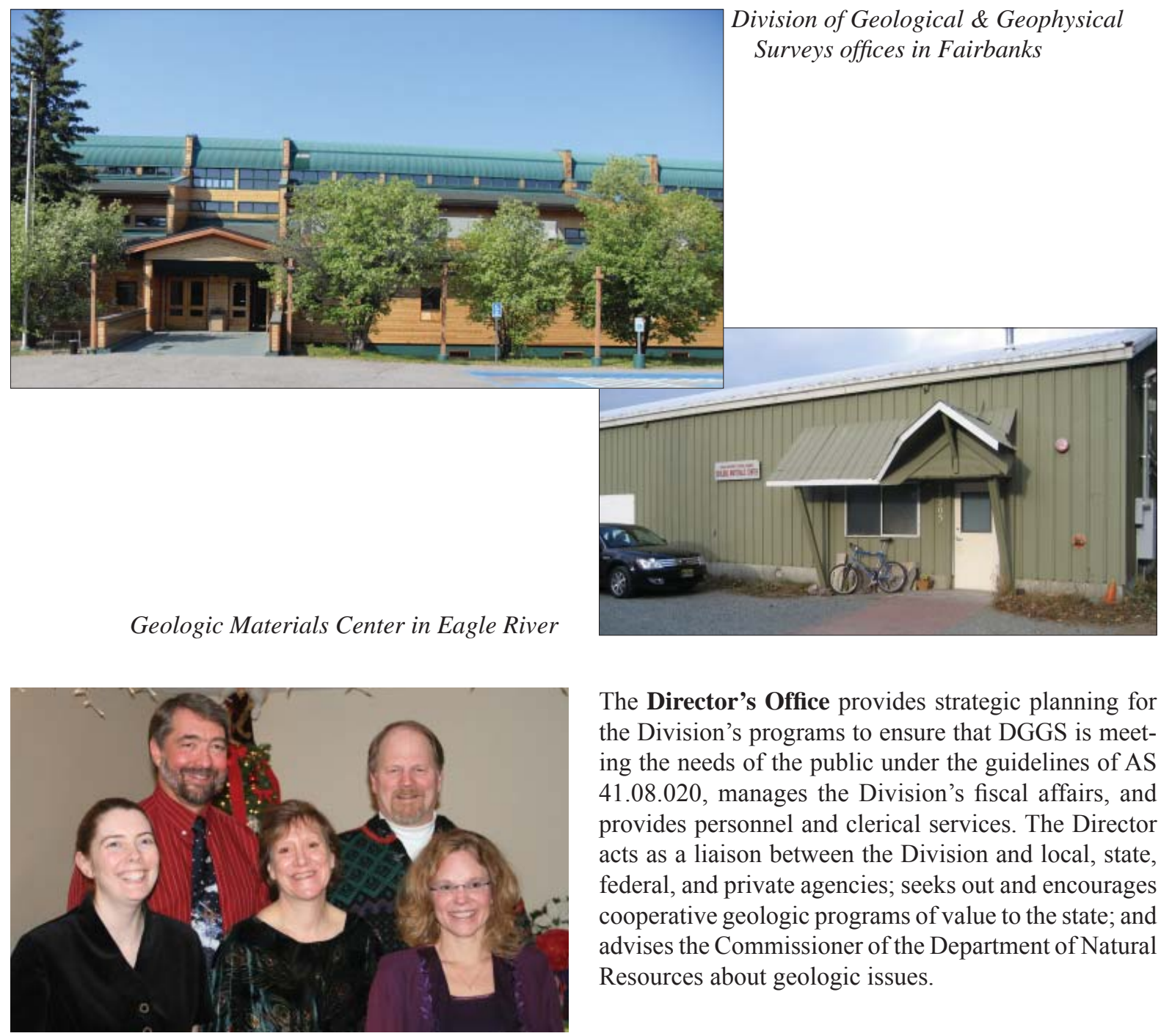

The Director's Office provides strategic planning for the Division's programs to ensure that DGGS is meeting the needs of the public under the guidelines of AS 41.08.020, manages the Division's fiscal affairs, and provides personnel and clerical services. The Director acts as a liaison between the Division and local, state, federal, and private agencies; seeks out and encourages cooperative geologic programs of value to the state; and advises the Commissioner of the Department of Natural Resources about geologic issues.

L то R: April Woolery, Rod Combellick, Rhea Supplee, Bob Swenson, Vickie Butherus 


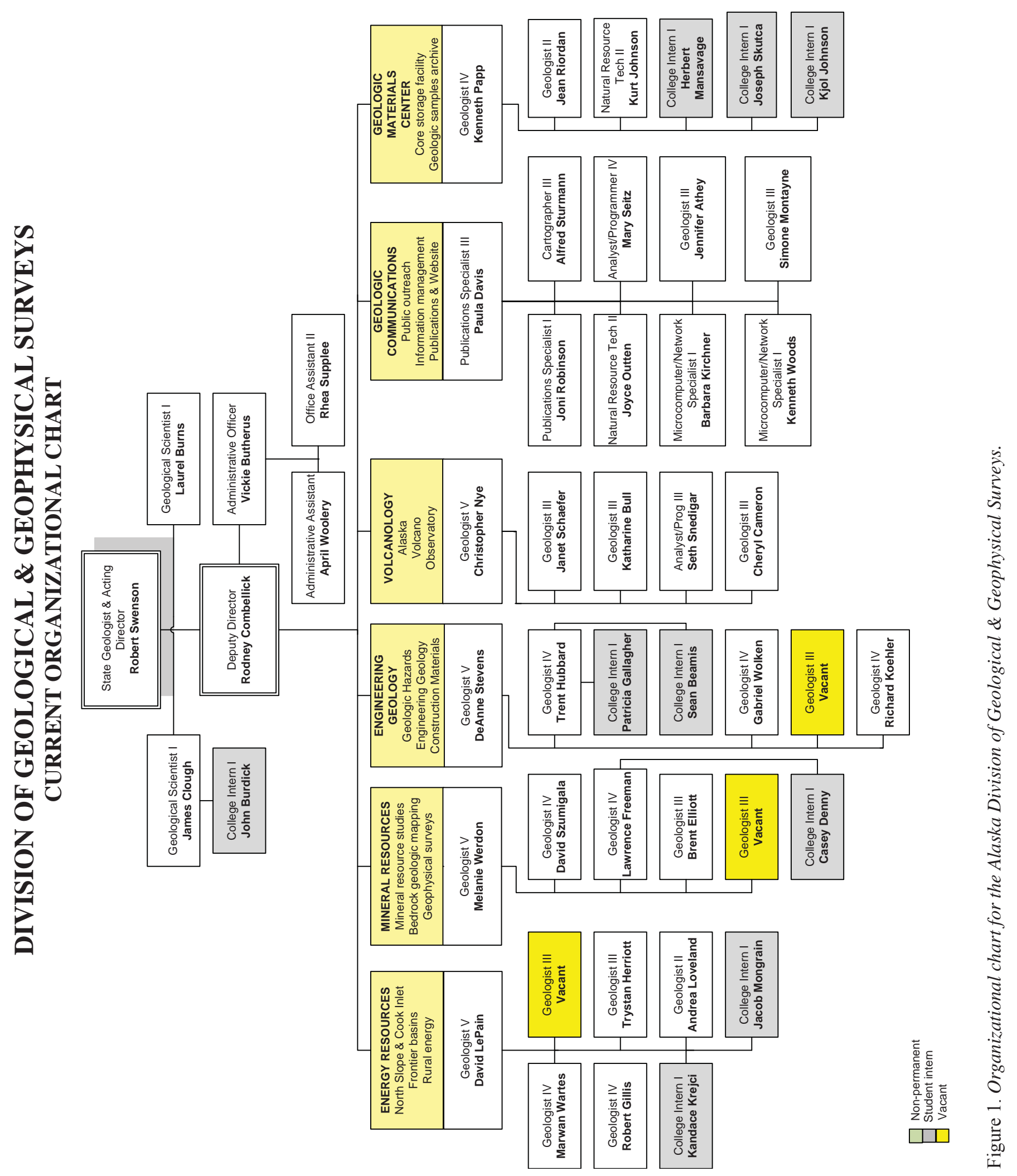


The Energy Resources Section generates new information about the geologic framework of frontier areas that may host undiscovered oil, gas, coal, or geothermal resources. Summary maps and reports illustrate the geology of the state's prospective energy basins and provide data relating to the location, type, and potential of the state's energy resources. The Energy Resources Section seeks to improve the success of state-revenue-generating commercial oil and gas exploration and development and to identify local sources of energy for rural Alaska villages and enterprises.

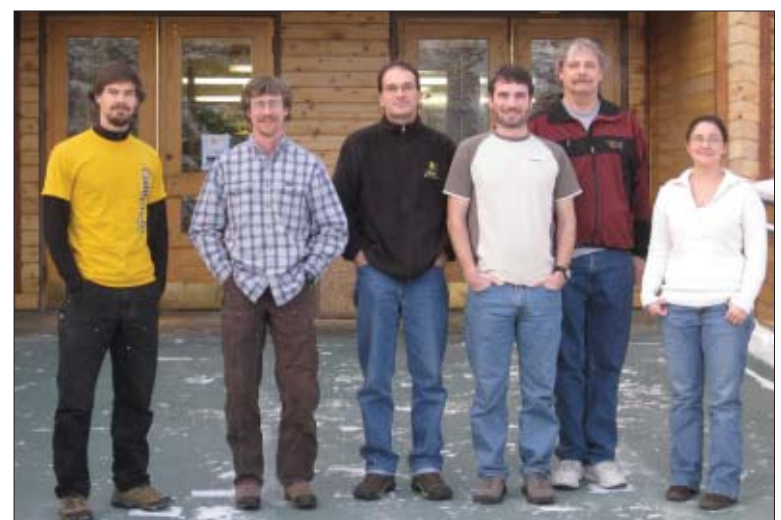

L to R: Trystan Herriott, Bob Gillis, Dave LePain, Marwan Wartes, Jim Clough, Andrea Loveland

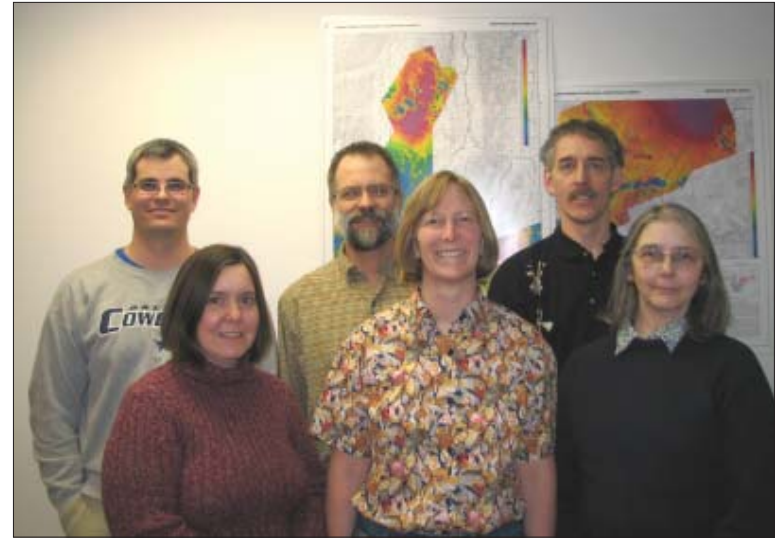

Back L то R: Brent Elliott, Larry Freeman, Dave

Szumigala

Front L to R: Jen Athey, Melanie Werdon, Laurel Burns
The Mineral Resources Section collects, analyzes, and makes available information on the geological and geophysical framework of Alaska as it pertains to the mineral resources of the state. Summary maps and reports illustrate the geology of the state's prospective mineral terranes and provide data on the location, type, and potential of the state's mineral resources. These data aid in the state's management of mineral development, and help to encourage mineral exploration in Alaska, which provides employment opportunities and revenue for Alaska's citizens.

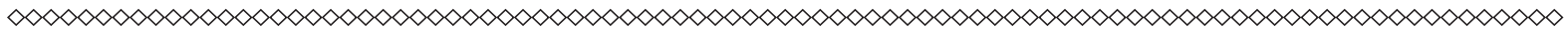

The Engineering Geology Section collects, analyzes, and compiles geologic data useful for engineering and hazard risk-mitigation purposes. Surficial-geologic maps portray the distribution of unconsolidated surficial geologic materials and provide information on their engineering properties and potential as constructionmaterials sources. Studies of major geologic hazards such as earthquakes, active faults, and tsunamis result in reports outlining potential hazards in susceptible areas. The section advises other DNR divisions and state agencies regarding potential hazard risks to proposed developments and land disposals.

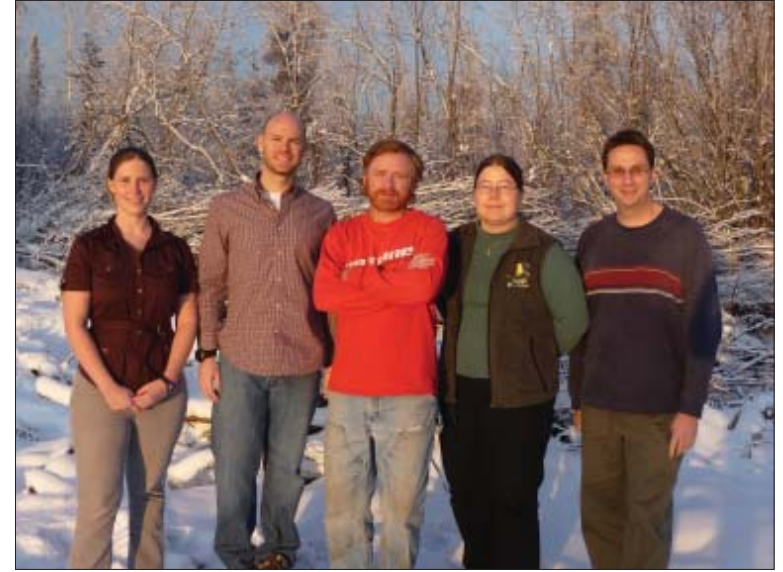

L то R: Trish Gallagher, Gabriel Wolken, Richard Koehler, De Anne Stevens, Trent Hubbard 


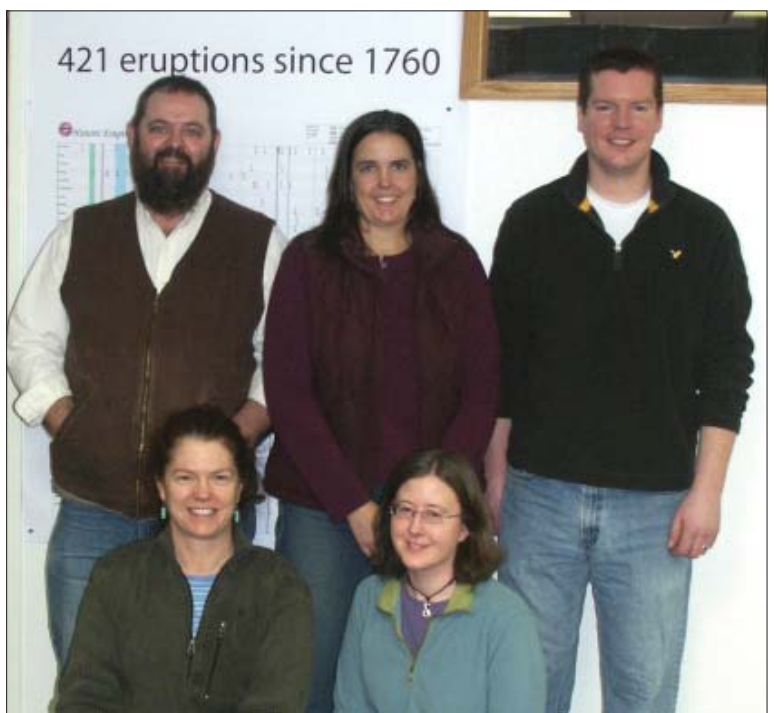

Васк L то R: Chris Nye, Janet Schaefer, Seth Snedigar Front L to R: Kate Bull, Cheryl Cameron
The Volcanology Section, established in 2007, focuses on processes and hazards associated with the more than 50 active volcanoes in Alaska. The section is home for the DGGS participants in the Alaska Volcano Observatory $(\mathrm{AVO}$; an interagency collaboration between the U.S. Geological Survey, University of Alaska Fairbanks Geophysical Institute, and DGGS). Volcanology Section staff conduct geologic studies of active volcanoes to estimate their future eruptive potential and behavior, thus aiding in mitigating volcanic-hazard risks. Results of these studies are released as maps and reports. The section also creates and maintains a large, public webaccessible database of information on volcano history and current activity (www.avo.alaska.edu) as well as an internal website providing communication, record keeping, and data sharing within AVO. In 2008 the section became heavily involved in geothermal resource issues, providing information to other agencies and the private sector and participating in state activities leading up to the geothermal lease sale at Mt. Spurr and providing technical reviews of proposals to the Renewable Energy Fund established by HB152.

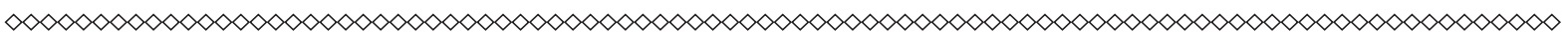

The Geologic Communications Section publishes and delivers Division-generated geologic information to the public and maintains and improves public access to Alaska's geologic and earth science information. Advances in computer technology have resulted in faster preparation of maps and reports and a wider awareness of DGGS's available Alaska geologic resources. This section designs, implements, maintains, and improves a database for the Division's digital and map-based geological, geophysical, and geochemical data; a database for the Division's physical samples that are housed in Eagle River; and websites for the Division (www.dggs. dnr.state.ak.us) and for the Alaska Seismic Hazards Safety Commission (http://www.dggs.dnr.state.ak.us/ seismic_hazards_safety_commission.htm).

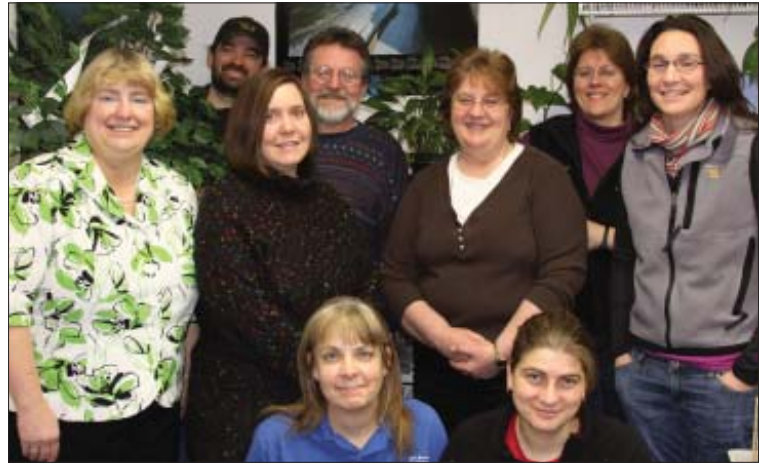

BACK: Ken Woods

Middle L to R: Paula Davis, Jen Athey, Fred Sturmann, Bobby Kirchner, Joni Robinson, Susan Seitz

Front: Joyce Outten, Simone Montayne

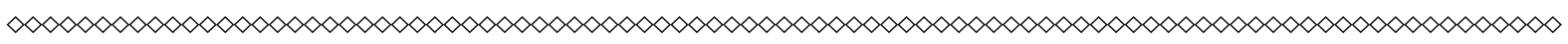

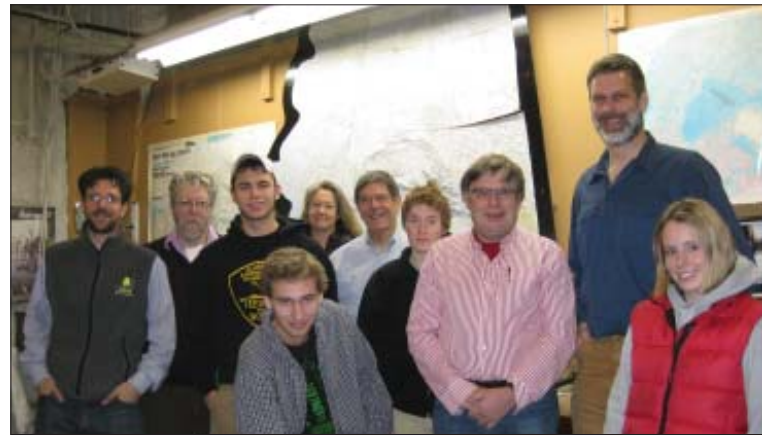

L To R: Ken Papp, Robert Ravn, Herbie Mansavage, Kjol Johnson, Jean Riordan, Don Hartman, Joseph Skutca, John Reeder, Kurt Johnson, Allison Empey
The Geologic Materials Center is the state's single central repository for representative geologic samples of oil- and gas-related well cores and cuttings, mineral deposit core samples, and regional geologic voucher samples. These materials are routinely used by industry to enhance the effectiveness and success of private-sector energy and mineral exploration ventures. New materials are continuously acquired. Access to the materials at the GMC is free. To ensure that the value of the GMC holdings is maintained over time, any new data or processed samples generated from privately funded analyses of the geologic materials stored there must be donated to the GMC database. 
The Alaska Seismic Hazards Safety Commission is charged by statute (AS $\$ 44.37 .067$ ) to recommend goals and priorities for seismic risk mitigation to the public and private sectors and to advise the Governor and Legislature on policies to reduce the state's vulnerability to earthquakes and tsunamis. The Commission is administered by DGGS and consists of 11 members appointed by the Governor from the public and private sectors for three-year terms. The Commission produces a separate annual report to the Governor and Legislature ak.us/seismic_hazards_safety_commission.htm.

\section{RELATIONSHIPS WITH OTHER STATE AGENCIES}

DGGS provides other DNR agencies with routine analyses and reviews of various geologic issues such as geologic-hazards evaluations of pending oil lease tracts; area plans; competitive coal leases; geologic assessments of land trades, selections, or relinquishments; mineral potential; and construction materials availability. DGGS's interaction with the Land Records Information Section in the DNR Support Services Division continues to increase as more geologic data are compiled and organized in digital format amenable to merging with

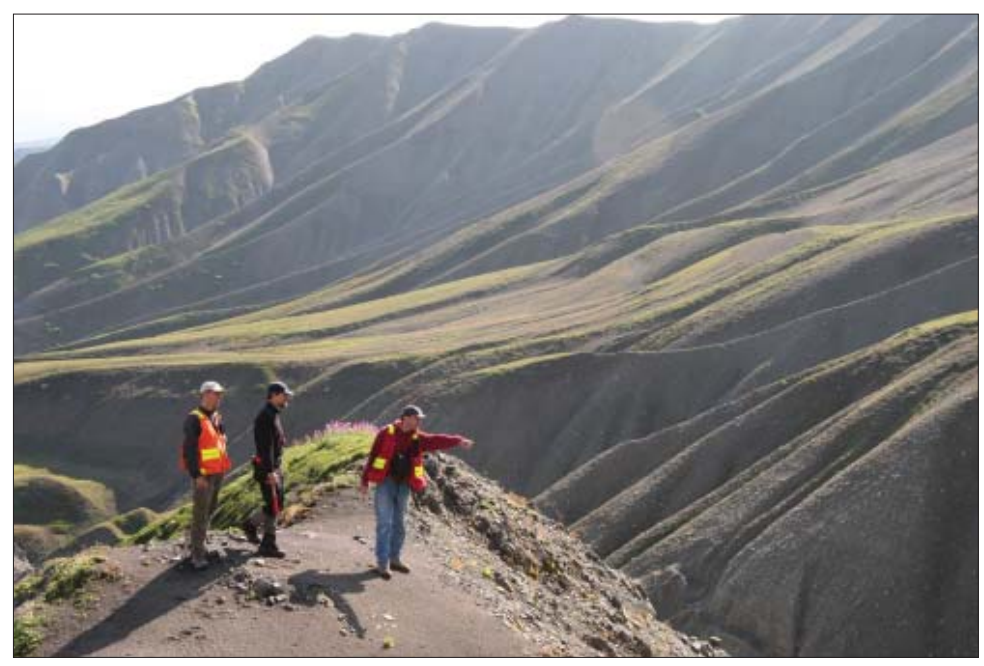
and has its own website at http://www.dggs.dnr.state.

in the Department of Military and Veterans Affairs to evaluate hazards, develop scenarios for hazards events, and prepare the State Hazard Mitigation Plan. Additionally, the Engineering Geology section participates in the Alaska Coastal Management Program to advise on geologic hazards issues and review coastal district plans and project applications. DGGS also evaluates resource potential around the state that may provide viable alternatives for energy development in rural Alaska.

Funding to support work requested by other DNR agencies mostly has been drawn from DGGS's yearly general fund appropriation. For larger inter-division efforts, however, the work is supported by interagency fund transfers, Capital Improvement Project (CIP) funding, federal cooperative agreements, or private industry grants that supplement DGGS's general funds.

\section{RELATIONSHIPS WITH LOCAL GOVERNMENTS}

Most of the cooperative efforts implemented by DGGS with borough and municipal governments are conducted on a mutually beneficial but informal basis. For example, DGGS participates in a federally funded cooperative program to develop tsunami-inundation maps for coastal communities. In Kodiak, Homer, Seldovia, and Seward, communities for which inundation maps have been prepared in recent years, the city and borough governments worked closely with DGGS and other project cooperators to help design the project outputs to best benefit their needs for planning evacuation areas and routes. Similar cooperative efforts are currently underway with Whittier and Sitka for the next tsunami-inundation maps to be generated by this program. The Engineering Geology section has also worked closely with several communities to develop a field-geoscience outreach program for middle- and high-school students in rural Alaska. Similarly, the Energy Resources section has worked other land information. The DGGS Energy Resources Section works closely with geologic personnel in the Division of Oil and Gas (DOG) on issues related to energy resources and in providing geologic control for the subsurface oil-related geologic analyses conducted by DOG. Each year DGGS prepares an annual report on the status of Alaska's mineral industry in cooperation with the Office of Economic Development in the Department of Commerce, Community \& Economic Development. The Engineering Geology section works closely with Division of Homeland Security \& Emergency Management closely with rural communities to help assess potential local energy resources.

\section{RELATIONSHIP WITH THE UNIVERSITY OF ALASKA}

DGGS has had a long and productive professional association with geoscientists and students in various departments of the University of Alaska. University of Alaska faculty work as project team members on DGGS projects and provide special analytical skills for generating stratigraphic, structural, geochemical, and 


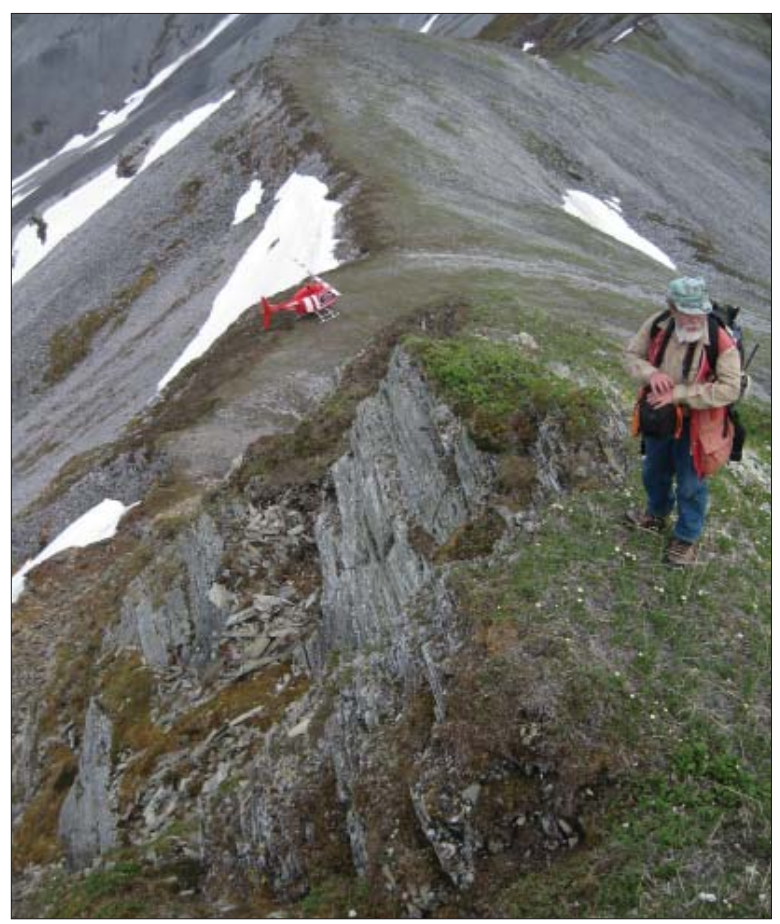

radiometric-age data. Collaborative research projects and program oversight help provide both organizations with focused work plans that complement one another. University students employed as DNR/DGGS interns also are an important part of the DGGS work force. While working on current DGGS projects, the students learn a wide variety of geology-related skills ranging from conventional geologic mapping and sample preparation techniques to modern digital database creation and geographic information systems.

Some graduate students are able to apply their DGGS intern work to their thesis projects. DGGS and the University make frequent use of each other's libraries and equipment.

\section{RELATIONSHIPS WITH FEDERAL AGENCIES}

DGGS often has cooperative programs with the U.S. Geological Survey (USGS), the U.S. Bureau of Land Management (BLM), and the U.S. Department of Energy. Periodically in the past, DGGS has also engaged in cooperative programs with the U.S. Minerals Management Service (MMS), National Aeronautics and Space Administration (NASA), and the National Science Foundation (NSF). DGGS receives some federal funds from matching grants for which the Division must compete nationally with other organizations on a yearly basis. DGGS has been successful in securing funds to support mineral inventory mapping, surficial and earthquake hazards-related mapping, volcanic-hazards evaluations, and studies related to oil \& gas and geothermal potential. Although DGGS has historically been very successful in receiving federal grants and appropriations, the process is highly competitive and these funds are therefore project specific or complementary to state-funded programs and do not replace state General Fund money. Federal funding is pursued only for projects that are needed to advance the division's statutory mission.

Three ongoing cooperative programs with federal agencies have provided support for key elements of the DGGS mission in recent years. One is the Alaska Volcano Observatory (AVO), a partnership established in 1988 and consisting of USGS, DGGS, and the University of Alaska Fairbanks Geophysical Institute. The USGS funds and administers the program for the purpose of providing a coordinated approach to mitigating volcano-hazard risks to the public, the state infrastructure, and air commerce. A second longstanding cooperative federal program is the STATEMAP component of the National Cooperative Geologic Mapping Program, established by Congress in 1992 and administered by USGS. STATEMAP provides matching funds for geologic-mapping projects according to priorities set by the Geologic Mapping Advisory Board (see below). A third major federal program is the Minerals Data \& Information Rescue in Alaska (MDIRA) program, established by Congress in 1997. DGGS has completed numerous MDIRA projects, administered by USGS and BLM, for the purpose of recovering, indexing, archiving, and

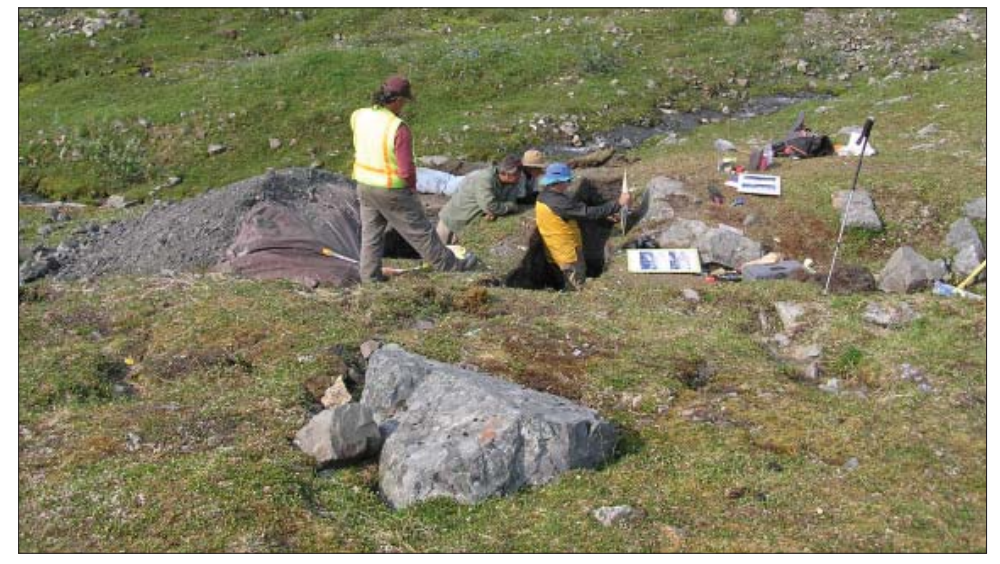

making publicly available minerals information at risk of becoming lost due to downsizing of public and private minerals-related programs. MDIRA funding for DGGS ended in early FY2010, although several related projects continue in FY2010. 


\section{ALASKA GEOLOGIC MAPPING ADVISORY BOARD}

The Alaska Geologic Mapping Advisory Board guides DGGS in pursuing its goal of providing earth science information to the Alaska public. A number of prominent geologists and community leaders, with a variety of backgrounds and a broad spectrum of experience in Alaska, have agreed to serve on the advisory board. The purpose of the board is multifold:

- To identify strategic geologic issues that should be addressed by the state.

- To inquire into matters of community interest relating to Alaska geology.

- To provide a forum for collection and expression of opinions and recommendations relating to geologic investigation and mapping programs for Alaska.

- To make recommendations toward identifying Alaska's diverse resources and promoting an orderly and prudent inventory of those resources.

- To increase public awareness of the importance of geology to the state's economy and to the public's health and safety.

- To promote communication among the general public, other government agencies, private corporations, and other groups that have an interest in the geology and subsurface resources of Alaska.

- To facilitate cooperative agreements between DGGS and other agencies, professional organizations, and private enterprise to develop data repositories and enhance the state's resource inventory and engineering geology programs.

- To communicate with public officials as representatives of groups interested in the acquisition of Alaska geologic information.

- To enlist public and legislative support for statewide geologic resource inventories and engineering geology programs.

The board held its first meeting in Fairbanks on October 22 , 1995, and meets usually three times a year to discuss state needs, review DGGS programs, and provide recommendations to the State Geologist. The members solicit and welcome comments and suggestions from the public concerning state needs and DGGS programs throughout the year.

Members of the board are:

\section{Irene Anderson}

Bering Straits Native Corporation, representing rural Alaskans in western Alaska

Irene Anderson is the Assistant Land Manager for Bering Straits Native Corporation. Mrs. Anderson has first-hand knowledge of the mineral, energy, and engineering geology needs throughout a wide region of rural Alaska.

\section{Greg Beischer}

Mill Rock Resources, President

Greg Beischer is a geologist and mining engineering technologist with many years of experience in the industry, specializing in exploration, development, and management of mineral resources.

\section{Curt Freeman}

Avalon Development Corporation, representing the minerals industry

Curt Freeman is President of Avalon Development Corporation, a consulting mineral exploration firm based in Fairbanks, Alaska.

\section{Peter Haeussler}

U.S. Geological Survey, representing the federal government, earthquakes hazards, and mapping interests.

Peter Haeussler is a geologist in the Anchorage office of the USGS Geologic Division, specializing in earthquake hazards, tectonics, and geologic mapping.

\section{David Hite}

Hite Consultants, representing the energy industry Dr. David Hite is based in Anchorage, Alaska, and has extensive knowledge of the geologic issues associated with Alaska's oil industry.

\section{Tom Homza}

Shell Exploration and Production, Alaska

Tom Homza is a Staff Geologist at Shell with more than ten years experience in oil and gas exploration and development in Alaska and represents the oil industry in mapping advice and structural interpretation.

\section{Paul Layer}

University of Alaska Fairbanks Department of Geology and Geophysics, representing the academic community

Dr. Paul Layer is an Associate Professor of Geophysics at the University of Alaska Fairbanks and former Head of the Department of Geology and Geophysics. He is currently Interim Dean of the College of Natural Science and Mathematics.

\section{David Stanley}

Alaska Department of Transportation \& Public Facilities (DOTPF), representing state government and the engineering geology and geotechnical community

David Stanley is Chief Engineering Geologist of DOTPF, overseeing geotechnical studies in support of development and maintenance of the state's highways and airports. 


\section{FY2009 ACCOMPLISHMENTS}

The Division of Geological \& Geophysical Surveys (DGGS) is charged by state statute to generate new, objective, peer-reviewed information about the geology of Alaska, the potential of Alaska's land for production of minerals, fuels, and construction materials, and the potential geologic hazards to its people and infrastructure. As in past years, in FY2008 the Division successfully performed geological and geophysical mineral inventory mapping, generated new geologic data to support energy exploration, conducted hazard investigations, performed geologic and hazards studies on active volcanoes, and streamlined geologic data archival and dissemination.

\section{MAJOR ACCOMPLISHMENTS IN FY2009}

\section{ENERGY RESOURCES}

- Conducted field geologic mapping, structural, and stratigraphic studies on the North Slope in collaboration with the Division of Oil \& Gas and U.S. Geological Survey, collecting geologic data for evaluating the hydrocarbon potential of the Brooks Range foothills.

- Published bedrock geologic maps in three areas of the northern Brooks Range foothills belt that have significance for oil and gas exploration and development on the North Slope: 400 square miles in the Cobblestone Creek area southeast of Umiat; 470 square miles in the Kanayut River area south of Umiat; and 620 square miles in the Kavik River area immediately west of ANWR.

- Drafted a multi-chapter volume addressing key geologic relationships in the central Sagavanirktok Quadrangle relevant to oil and gas exploration on the North Slope.

- Conducted structural and stratigraphic studies in Cook Inlet in collaboration with the Division of Oil \& Gas, collecting data relevant to assessing the hydrocarbon potential of Cook Inlet basin.

- Initiated review of fossil fuel and geothermal energy resources statewide for release as a series of short reports summarizing geoscience-based energy options in rural Alaska.

- Drafted a multi-chapter volume addressing the geology of potential reservoir sands in Cook Inlet.

- Presented new data relevant to oil and gas exploration in the North Slope foothills and upper Cook Inlet to government and industry representatives at the annual meeting of the American Association of Petroleum Geologists.

- Presented new data relevant to the oil and gas potential of the Bristol Bay region at an Alaska Geological Society meeting.
- Presented new data relevant to the tectonic evolution of the upper Alaska Peninsula and lower Cook Inlet to an international community at the 11th International Conference on Thermochronometry.

- Presented new data relevant to oil and gas exploration in the North Slope foothills and upper Cook Inlet to academic, government, and industry representatives at the annual Alaska Geological Society Technical Conference.

\section{Mineral Resources}

- Published Alaska's Mineral Industry 2007 (Special Report 62), an authoritative annual report of statewide mining activity, in collaboration with the Alaska Department of Commerce, Community and Economic Development.

- Completed a draft bedrock geologic map of 273 square miles of a portion of the Eastern Bonnifield mining district, northern Alaska Range.

- Completed a draft bedrock geologic map of 677 square miles of the Alaska Highway Corridor between Dot Lake and Tetlin Junction, Interior Alaska.

- Initiated bedrock geologic mapping and mineral-resource assessment of 129 square miles of the Mentasta-Slana area, eastern Alaska Range, Alaska.

- Released airborne geophysical surveys of 442 square miles of the Mentasta-Slana area, eastern Alaska Range, Alaska.

- Initiated airborne geophysical surveys of 644 square miles of the Moran area, Tanana and Melozitna quadrangles, Interior Alaska.

\section{EngineERING Geology AND HAZARDS}

- Completed field work and preparation of draft maps and reports resulting from geologic mapping and hazards evaluation of over 700 square miles along the Alaska Highway between Dot Lake and Tetlin Junction as the second part of a continuing study of the proposed natural gas pipeline corridor. Publication of surficial geology, engineering geology and permafrost maps and reports are anticipated late in 2009.

- Completed preliminary geologic photointerpretation of surficial geology and permafrost distribution for 800 square miles along the Alaska Highway between Tetlin Junction and the Canada border, in preparation for fieldwork for the third segment of the proposed natural gas pipeline corridor. Publication anticipated in fall of 2010. 
- Presented new data at the annual Alaska Geological Society meeting on active fault studies in the Delta Junction-Dot Lake segment of the proposed gas pipeline corridor, and surficial-geologic mapping in the Sagavanirktok Quadrangle.

- Organized and hosted an informal workshop for pipeline companies, regulatory agencies, and the public to communicate field observations and current understanding of data related to geologic and hazards studies in the proposed natural gas pipeline corridor from Delta Junction to the Canada border.

- Supported the Alaska Division of Oil \& Gas by writing, revising, and updating natural hazards reports for lease sale documents.

- Supported the Alaska Department of Transportation and Public Facilities by drafting a scope of work for a GIS-searchable inventory for construction-materials sites along major transportation corridors, and by reviewing a preliminary report on naturally-occurring asbestos and related considerations for construction-materials sites.

- Participated in multiple meetings and discussions as part of the Statewide Digital Mapping Initiative (SDMI), which has the primary goals of acquiring new and better digital map data for Alaska, including orthoimagery and digital elevation models, and making existing map products more easily available.

- Supported the Alaska Coastal Management Program (ACMP) by reviewing Coastal Project Questionnaires and advising project review coordinators on natural hazards issues.

- Published a surficial-geologic map of the Salcha River-Pogo geophysical survey tract.

- Completed agency reviews regarding potential geologic hazards and engineering-geologic considerations for multiple DNR land disposal and subdivision projects and for Environmental Impact Statements of the U.S. Department of the Interior's Bureau of Land Management (BLM).

- Taught teacher workshops in Anchorage and Unalakleet as part of DGGS's ongoing involvement in MapTEACH (Mapping Technology Experiences with Alaska's Cultural Heritage), a geoscience education-outreach project developed by DGGS in collaboration with the University of Alaska Fairbanks and University of Wisconsin-Madison. MapTEACH is now being run by the University of Alaska Geography program, which has embraced it as its "flagship K-12 outreach program."

- Secured funding from the federal Coastal Impact Assistance Program (CIAP) to initiate a major new
DGGS program of coastal community geohazards evaluation and geologic mapping in support of community and coastal district planning.

- Secured Enhancement Grant funding through the Alaska Coastal Management Program (ACMP) to update and revise the DGGS online Guide to Geologic Hazards in Alaska, a bibliographic database with links to scanned maps and documents published by DGGS and the U.S. Geological Survey (USGS) with the goal of keeping it current and making it more user-friendly to coastal district planners, ACMP, and project applicants.

- Provided administrative support for the Alaska Seismic Hazards Safety Commission.

\section{VolCANOLOGY}

- Played a key role in Alaska Volcano Observatory (AVO) monitoring and response to major eruptions at Okmok, Kasatochi, and Redoubt volcanoes, and a moderate eruption at Cleveland Volcano.

- Performed major multiple geologic responses and analyses for the 2009 Redoubt eruption (cooperative interagency efforts) and provided focused information to federal and state regulatory agencies about lahars and risks to the Drift River Oil Terminal.

- Organized and led an 8-person, 2-week field effort on Redoubt Volcano in summer 2008 (before the 2009 eruption), and performed data compilation, digitizing and analysis, as part of a project to update the geologic map and hazard assessment of the volcano.

- Responded to 2,500 emails to the AVO website, mostly in association with the 2008 eruptions of Okmok, Cleveland, and Kasatochi, and the 2009 eruption of Redoubt.

- Conducted annual water quality monitoring at Mother Goose Lake and the King Salmon River by collecting water samples and measuring the $\mathrm{pH}$ of natural acid water draining from Chiginagak volcano's crater lake. Acidification of these drainages has eliminated once-robust salmon runs since 2005.

- Conducted fieldwork to document the devastation of Kasatochi Island's ecosystem by the 2008 eruption and reestablishment of that ecosystem. This collaborative project of the USGS, US Fish and Wildlife Service, and the University of Alaska is funded by the North Pacific Research Board and the USGS and addresses geology, ornithology, botany, the nearshore marine ecosystem, entomology, and soil development. 
- Provided field, GIS and, database support to document and describe the 2008 eruption of Okmok volcano

- Conducted fieldwork as part of a collaborative research project with the U.S. Geological Survey and U.S. Forest Service researchers to describe newly identified Quaternary (recently active) volcanoes in southeast Alaska.

- Created a comprehensive database of Alaska's $\sim 1200$ Quaternary volcanic centers, with associated chemical, morphology, and age data to aid in identifying regional variations and to facilitate a revised, uniform, volcano name reference system.

- Facilitated technology transfer by installing the Hazard Notification System (HANS) software at the Hawaii Volcano Observatory and trained personnel in its use. This software was developed at DGGS as part of AVO website development.

- In response to nearly overwhelming web traffic during the Redoubt 2009 eruption, instituted measures to accommodate significantly more users during excessive server load

- Created the "alaska_avo" Twitter page which has more than 8,000 followers; information updates and informal notifications are sent to this page

- Maintained the existing modules of the database of AVO's public and internal web sites, including bibliography, eruption histories, and images.

- Provided technical review of geothermal proposals to the HB 152 Renewable Energy Fund.

\section{Geologic Information ManAgement AND \\ DeLIVERY}

- Sold 864 reports for total revenue of $\$ 5,721.69$, and distributed 1,990 complimentary copies of reports at conferences, to teachers, and to fill general requests. Public contacts for the year included 97 walk-ins, 7 fax orders, 59 phone calls, 24 e-mail requests, and 21 mail requests.

- Published 1 Annual Report, 38 Geophysical Reports, 2 Information Circulars, 2 Newsletter issues, 7 Preliminary Interpretive Reports, 1 Raw Data File, 5 Reports of Investigation, and 1 Special Report.

- At the request of another state agency, salvaged corrupted GIS data related to geologic conditions at Shishmaref from a project created prior to 2000. The recovered data were converted and used to create map layers.

- Attended and presented a poster at the 2009 Geoscience Data Preservation Techniques Workshop in Indiana. The poster, "Alaska Geologic Materials
Center Inventory Database: A web-accessible geologic sample catalog," was very well received by conference participants and touted as an excellent example of data preservation techniques.

- Loaded, quality controlled, and made available Geologic Materials Center (GMC) Data Reports on the DGGS website; 358 Data Reports are now available as a separate publication series.

- Added 63 new digital geologic datasets using an internal web application that helps DGGS staff members to post geospatial data on the website. All published datasets include FGDC-compliant metadata. In FY09, there were 672 dataset downloads from the DGGS website.

- Migrated the Geochronologic Database for Alaska from Microsoft Access into the DGGS Oracle database. The database provides geologic age dates for rocks around the state and will be available to the public online in FY10.

- Continued to populate at-risk legacy digital and paper-based data into DGGS's Oracle database. Notable accomplishments include loading the MDIRA-funded geochronology database; the release of metadata files for each online GIS dataset published during the fiscal year; and reconciliation and clean-up of the scanned image archive.

- Completed development of a bulk uploading program that will allow staff to upload large files of GMC sample inventory data directly into Oracle. A prototype of a search engine was completed, which when finalized in late FY10, will allow the public to search the sample inventory online.

- Organized and cataloged the remainder of the collection received from the U.S. Bureau of Land Management's John Rishel Mineral Information Center in Juneau when it closed.

- Represented DGGS during career day at UAF. Spoke with prospective interns and other persons potentially interested in geology careers and working at DGGS.

- Presented "An introduction to GIS" at the University of Alaska, Department of Engineering. This is part of our ongoing outreach effort at DGGS.

\section{Geologic Materials Center}

- Hosted 492 visitations to the Alaska Geologic Materials Center (GMC) in Eagle River by industry, government, and academic personnel to examine rock samples and processed materials. These visitations helped generate 4,844 processed oil and gas related microscope slides and 8 hard-rock mineral and oil and gas technical data reports. 
- Received and catalogued rock samples for 27 new oil and gas wells, representing 270,000 feet of well samples, from the Alaska Oil and Gas Conservation Commission and industry.

- Received and catalogued 11 pallets of rock reject and pulp from core and soil samples of the Calista Corporation NYAC (a name derived from New York Alaska Company) gold property of Tuluksak River in southwestern Alaska. The Calista Corpora-tion also kindly donated one 40 -foot metal storage container.

- Received and catalogued six crates of core from Amchitka Island (the rough equivalent of 22 pallets of core, 24,000 pounds) from the Civil Engineering Department of the University of Alaska Fairbanks. The cores relate to the Amchitka nuclear tests and are not all of the cores taken by the U.S. Government.

- Received and catalogued eight pallets of unfrozen (previously frozen) continuous core (107'-2,300' total depth) for the Anadarko Petroleum Corpo- ration Hot Ice No. 1 hole, which was from their methane-hydrate exploratory project in northern Alaska. These materials were received from the Petroleum Engineering Department of the University of Alaska Fairbanks.

- Received and catalogued six pallets of iron-titanium-platinum core from the Bristol Bay Native Corporation Kemuk Mountain Prospect, Nushagak basin, southwestern Alaska; representing 8,338 feet of core from 14 holes.

- Received 19,000 pounds of surface samples from DGGS geologists.

- Organized, documented and detailed approximately 40 percent of the hard-rock material stored in 18 Conex containers as part of the GMC Database Inventory Integration project. Their efforts will improve the in-house materials database inventory, allowing staff to help users of the facility find information more quickly and pave the way for a future web interface to query the available materials at the GMC.

\section{KEY ISSUES FOR FY2010-2011}

\section{Infrastructure Projects and Public Safety}

- Development of Alaska's vast resource base requires reasonable access to world markets. Providing geologic data for infrastructure maintenance and development will remain a key challenge for DGGS.

- The Alaska Gasline Inducement Act (AGIA) pipeline will require vast amounts of construction materials information and geologic hazards data to allow timely and safe design and development. DGGS is currently acquiring those data, but will need to accelerate the current pace to supply the needed maps and information.

- Continued arctic warming will undoubtedly increase maintenance requirements on much of Alaska's current roads and transportation corridors. Identifying geologic hazards and areas prone to failure will be necessary to mitigate this change. Increased materials requirements will likewise strain Department of Transportation and Public Facilities' (DOT/PF) ability to address this issue. DGGS will work with other state agencies to provide modern analytical techniques for this work.

- Large projects that will develop Alaska's vast natural resource base and sustain the State's economy into the 21 st century require baseline data and hazards analysis so permitting can take place in a reasonable timeframe and the environment can be properly protected. Most areas have only minimal data and mapping that will be necessary to undertake these activities in the near term.

- Population continues to expand in some areas of the state, and those regions (like Wasilla) have essentially no baseline data on which to base zoning efforts and restrictions.

- DGGS will be challenged to provide geologic information for infrastructure, human, and economic development, as well as transitioning our hydrocarbon-based economy to a sustainable future. All construction in the state requires a complete analysis of the inherent geologic risks that are commonplace but poorly understood in most areas of Alaska.

\section{Updating and Improving the Alaska Geologic Materials Center}

- A repository of rock core, samples, and data is critical for any state (or country) that relies on resource development as a key component of its economy.

- The Geologic Materials Center (GMC), located in Eagle River, is Alaska's rock data repository and is the "first stop" for any industry or academic researcher who is attempting to identify and understand the complex geology of the numerous resource-rich areas throughout Alaska. 
- Providing efficient and comprehensive access to these data is critically important for viable exploration programs, for both seasoned Alaska explorers and new companies that are trying to identify potential exploration areas.

- Although the current condition of the GMC is being maintained, the facility is more than 150 percent above its designed sample-storage capacity, and is very poorly designed to handle the regular and frequent requests for reasonable access to the material.

- The GMC currently utilizes 60 portable containers as temporary storage facilities for recent sample acquisitions. These shipping containers are unlighted, unheated, and house thousands of feet of core, some of which will disintegrate with repeated freeze-thaw cycles. It is important to note that this collection represents hundreds of millions of dollars of acquisition and preservation costs and is in significant risk of damage or loss.

- The core and sample observation areas are essentially unusable for confidential work and examination of more than a few feet of core length. An exploration company's ability to keep their activities confidential is critical to exploration success in a fiercely competitive environment. Often the core must be taken off site for substantial projects, creating a significant security threat to the unique core, and an expensive alternative for the exploration company. All of these factors could result in a reluctance by users to make use of the facility because they must go through the onerous effort of transporting and unnecessarily handling the material at risk.

- A facility concept study, funded through a special federal appropriation, was finished in July 2006. The study identified the most feasible options for design and provided cost estimates for various configurations. It is the basis for our FY09 CIP-funded project to support the next phase, which is architectural and engineering design of the facility.

- A significant challenge for DGGS over the near term will be to convince the public, lawmakers, and government officials of the importance of upgrading this facility and providing the funding necessary to keep this critical data source safe and accessible. We have now initiated a multi agency task force that will finalize the site selection and identify public funding sources and key legislators to support the project.

Changes in local energy supply and consumption

- A complete, or even partial, re-tooling of the state's energy supply will be a non-trivial exercise.
Providing money to make changes is a first important step; however, there must be oversight and monitoring of projects to avoid the substantial mistakes of the past. This is a problem that will not be solved by pouring state funding into a trough and yelling, "Come and get it."

- The Alaska Energy Authority has completed the first and second rounds of requesting proposals and distributing state funds, by the way of grants, to begin assessing and developing sustainable forms of energy in all corners of the state. DGGS will continue to be intimately involved in reviewing the proposals for resource existence, methodology, and data review. DNR will be tasked with the substantial job of regulating the hundreds of projects that have the real potential to significantly impact the state's natural resources.

- Sustained high energy prices and the current push to curtail carbon-based fuel use through Federal legislation have had a significant impact on, and threaten to severely alter the economies of rural Alaska and threaten the viability of rural infrastructure.

- Many remote areas of the state lack sufficient geologic information on potential alternate forms of energy such as shallow natural gas, coal, geothermal, and conventional gas that will be necessary bridge fuels as the state and local governments grapple with increasing energy cost and decreasing availability.

- Misinformation about viable alternate energy sources is rampant and many expensive mistakes can be avoided by getting the information in the hands of the local governments and decision makers.

- Legislation passed 2008 to help citizens weather the difficult financial burdens associated with fuel cost increases in Alaska will continue to stress available limited supplies of data, expertise, and reputable contractors that will be needed to perform the necessary analyses and research.

- DGGS will be challenged to provide pertinent and timely data on numerous fronts, and is requesting additional capital project funds to begin a long-term program that addresses the occurrence of locally available energy sources and makes that data available to those that can use it to move Alaska into a sustainable energy future.

\section{Response to data needs for adaptation to a changing arctic climate}

- Alaska will, over the coming years, be a national focal point for indications and impacts of climate 
change. Our ability to provide reliable, unbiased data for the development and evaluation of emerging policy and statute changes will be very important for achieving reasonable, long-range planning and mitigation. We will continue to collect geologic and hazards data needed to help mitigate and adapt to the changing environment, and make that data available to the public.

- Geologic information will be needed in a number of key climate-related mitigation efforts. Most importantly, these data will be required in areas of coastal development and critical infrastructure where ground settlement from thawing permafrost, increased erosion and landslide hazards, and changes in hydrologic systems (both surface and subsurface aquifers) will be prevalent.

- Historically, the state has relied on site-specific hazards analyses related to ongoing development or permit approval. The recognition of significant change across the arctic will require that regional baseline data be gathered and made available to communities and local planners so that mitigation and new development can progress with physical and environmental change in mind.

- Continued population growth and development in Alaska will continue to encroach on areas with heightened geohazard risk.

- Because of the nearly ubiquitous need for modern geologic mapping and data in impacted areas of the state, DGGS will be tasked with acquiring geologic data, producing maps, and identifying risks (information that can be used in both shortterm and long-term planning). In some cases it will be critical to have this data available in crisis situations.
- DGGS will work with many other agencies (with a wide range of mandates) in a coordinated effort so that the most important needs are addressed, and redundancy is minimized.

- The key challenge will be in the prioritization of the areas, as there is much more need for data than personnel and funding to acquire it.

\section{Sustained High-level Commodity Prices}

- High wages and many openings for highly trained personnel in the natural resource exploration and extraction industries present a challenge for DGGS to meet demands for geologic information.

- Loss of personnel to industry and retirement remained a key challenge in FY10, and will likely continue into the foreseeable future

- Increased activity in minerals and oil and gas exploration puts a noticeable strain on all facilities and programs. Our effort to provide critical geologic data to these entities will be challenged as more and more end-users of our products demand quicker and more comprehensive response. The main challenges will arise from a static state budget and our ability to plan for the rapidly changing needs of the resource development community, and to gather the required field information in the face of rising operating costs.

- Spikes in the exploration cycle also create a situation where high-paying jobs become abundant, and opportunities for experienced geoscientists become commonplace. A significant challenge for DGGS will be our ability to attract and retain key personnel in this very competitive environment.

\section{DGGS FY2010 PROGRAM}

\section{PROGRAM FOCUS}

DGGS develops its strategic programs and project schedule through consultation with the many users of geologic information-state and federal agencies, the federal Congressional delegation, the Alaska State Legislature, professionals in the private sector, academia, and individual Alaska citizens. Their input to DGGS programs comes through the Alaska Geologic Mapping Advisory Board, liaison activities of the Director, and personal contact between DGGS staff and the above groups.

The FY2010 DGGS program focuses on projects designed to foster the creation of future Alaska naturalresource jobs and revenue and to mitigate adverse effects of geologic hazards. For the foreseeable future, much of the economy will continue to depend on developing the state's natural resources. Within that future, energy and mineral resources constitute a major portion of the state's wealth. Mitigating the effects of geologic hazards helps preserve public safety and private investments by fostering sound design and construction practices. Both resource development and hazard risk mitigation depend heavily on the availability of reliable geologic information.

The role of DGGS in state revenue generation and the maintenance of Alaska's economy is strategic. DGGS provides objective geologic data and information used by in-state, national, and international mineral and energy companies, construction companies, air carriers, other 
DNR agencies, Department of Commerce, Community \& Economic Development, Department of Transportation \& Public Facilities, Division of Homeland Security \& Emergency Management, and the Federal Emergency Management Agency. DGGS geologists provide geologic and geophysical information to assist prospectors, mineral, oil, and gas explorationists and others to explore for, discover, and develop Alaska's subsurface resources. DGGS is a central repository of information on Alaska geologic resources and a primary source of information for mitigating geologic hazard risks. To focus attention on Alaska's subsurface resource potential and geologic hazards, DGGS makes the state's geologic information available on statewide, national, and international levels. Through its Geologic Materials Center in Eagle River, DGGS also provides access to physical samples collected by private companies and government agencies.

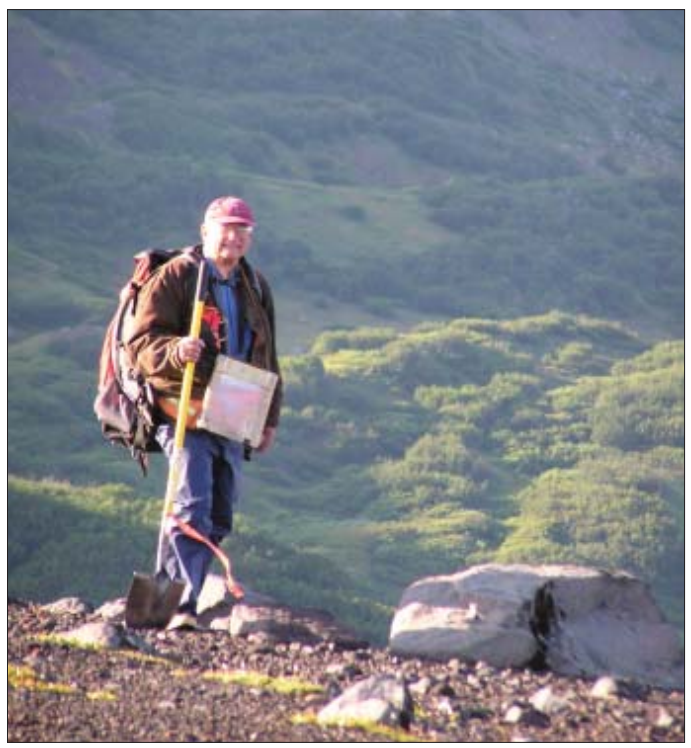

Minerals Data and Information Rescue in Alaska (MDIRA) Program

Downsizing of federal and state agencies in Alaska during the late ' 80 s and early ' 90 s placed at risk an extensive body of geological, geochemical, mineral, and mineral-development data that had been collected by federal, state, and private organizations over the past century. These data are archived in various locations offering various levels of storage capacity, quality, and accessibility. The budget shortfalls for federal and state archival functions created a need to develop aggressive plans for assembling, maintaining, and most importantly, creating value from this data legacy. For the purpose of this effort, "at risk data" is defined as any geologic data or voucher samples existing in substandard storage sites or in a mode in which data may be subject to irretrievable loss or degradation, or may be unavailable to meet the needs of its intended users. Since 1998, a liaison committee comprising representatives from the Alaska Miners Association, Alaska Native corporations, University of Alaska, Alaska Department of Natural Resources, and independent mining industry consultants has guided the implementation of the Alaska minerals data rescue efforts through a federally funded program entitled Minerals Data and Information Rescue in Alaska (MDIRA). DGGS projects supported in whole or in part by this program have been undertaken by the Mineral Resources and Geologic Communications sections. DGGS's three remaining MDIRA projects are scheduled to be completed in 2010; in the FY2010 Program Summaries that follow, these projects are indicated by an asterisk $(*)$.

FY2010 DIVISION EXPENSE BUDGET

(estimated expenses in thousands of dollars)

Program

Energy Resources

Mineral Resources

Engineering Geology

Volcanology

Geologic Communications

Geologic Materials Center

Administrative Services

Seismic Hazards Safety Commission

Total by funding source

\begin{tabular}{rrr}
$\begin{array}{c}\text { General } \\
\text { Fund }\end{array}$ & \multicolumn{1}{c}{ CIP } & $\begin{array}{c}\text { Federal } \\
\text { Receipts }\end{array}$ \\
901.4 & 55.0 & 244.0 \\
$1,424.0$ & 85.0 & 82.0 \\
528.5 & 414.0 & 0.0 \\
20.0 & 0.0 & 806.0 \\
750.0 & 375.0 & 17.0 \\
262.7 & 45.0 & 123.0 \\
398.0 & 0.0 & 0.0 \\
10.0 & 0.0 & 0.0 \\
$\mathbf{4 , 2 9 4 . 6}$ & $\mathbf{9 7 4 . 0}$ & $\mathbf{1 , 2 7 2 . 0}$
\end{tabular}

Interagency

\& Program Receipts

Total

$\begin{array}{rr}145.0 & 1,345.4 \\ 5.0 & 1,596.0 \\ 120.0 & 1,062.5 \\ 0.0 & 826.0 \\ 29.0 & 1,171.0 \\ 50.0 & 480.7 \\ 3.0 & 401.0 \\ 0.0 & 10.0 \\ \mathbf{3 5 2 . 0} & \mathbf{6 , 8 9 2 . 6}\end{array}$




\section{PROGRAM SUMMARIES}

\section{STATE GEOLOGIST/DIRECTOR}

The Director's Office provides leadership and coordination for the activities of the Division through the State Geologist/Director, Deputy Director, and administrative staff.

\section{OBJECTIVES}

1. Provide executive leadership for the Geological Development component of DNR's program budget and act as liaison between the Division and the DNR Commissioner's Office, other state agencies, Legislature, Governor's Office, and local, federal, and private entities.

2. Stimulate exploration, discovery, and development of the geologic resources of the state through implementation of detailed geological and geophysical surveys as prescribed by AS 41.08.

3. Provide geologic information to mitigate the adverse effects of natural geologic hazards.

4. Provide secure archival storage and efficient public access to the state's growing legacy of geologic information, and energy- and minerals-related reference cores and samples.

\section{TASKS}

- Prepare annual Division funding plan including Alaska General Fund base budget, Capital Improvement Project budget, interagency programs, and federal initiatives.

- Inform Alaska state legislators, Governor's Office, Alaska federal delegation, and the public about the DGGS geologic program and its significance.

- Focus the Division's geologic expertise on addressing Alaska's highest priority needs for geologic information.

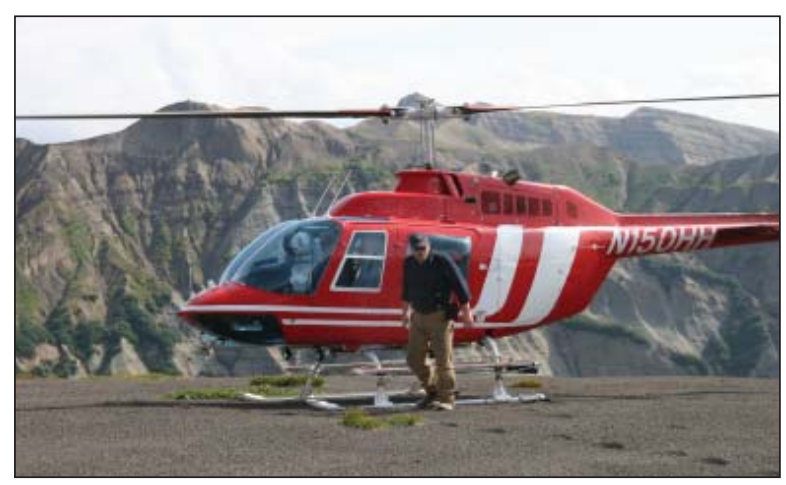

ENERGY RESOURCES

The Statewide Energy Resource Assessment program produces new geologic information about the state's oil, natural gas, coal, and geothermal resources. As both State and national oil and gas reserves continue to decline, and associated price volatility becomes the norm, it will become exceedingly important that new energy resources are identified in the state to help offset declining conventional reserves and state income. An additional need that must be addressed in the short term is that of identifying affordable energy resources that can be economically developed for smaller local markets. As a consequence, there is a continual need for acquisition and dissemination of fundamental geologic data using modern technology that will enable industry and local governments to better focus exploration efforts on prospective areas beyond the currently producing fields. Recent DGGS stratigraphic studies and geologic mapping in the central and eastern North Slope are stimulating exploration interest in the Brooks Range foothills. This underexplored frontier province appears to be dominantly gas-prone and has the potential to yield additional reserves for the proposed natural gas pipeline. In late FY2009, DGGS resumed stratigraphic studies in the Ivishak River region east of the TransAlaska Pipeline corridor in the Sagavanirktok Quadrangle of the east-central Brooks Range foothills. This area encompasses approximately 510 square miles, and includes stratigraphic and structural elements important to understanding the oil and gas potential of Alaska's North Slope.

Predicted gas deliverability shortfalls in the south-central Alaska market have resulted in a significant increase in exploration interest in Cook Inlet Basin. With this new interest the exploration focus has shifted from permeable sandstones in structural traps to gas in tight sandstone formations and stratigraphic plays. To stimulate sustained exploration interest, DGGS initiated a multi-year study of this basin in FY2007 to provide relevant highquality data to help evaluate resource potential of tight formations and stratigraphic traps. This project focuses on building a robust model of the basin's stratigraphy to help predict the distribution of potential sandstone reservoirs and to provide a better understanding of 
parameters controlling reservoir quality and producibility. In FY2009 DGGS resumed stratigraphic and structural studies along the northwestern margin of the basin, in the Tyonek Quadrangle. This area includes some of the same rock formations that produce oil and gas in nearby fields such as Beluga, North Cook Inlet, and Granite Point. Features studied in outcrop are important for developing new techniques that will allow the productive life of these fields to be extended and help in the recognition of stratigraphic traps and reservoirs in tight formations. In late FY2009 DGGS initiated stratigraphic and structural studies on the western side of lower Cook Inlet, across from Ninilchik and

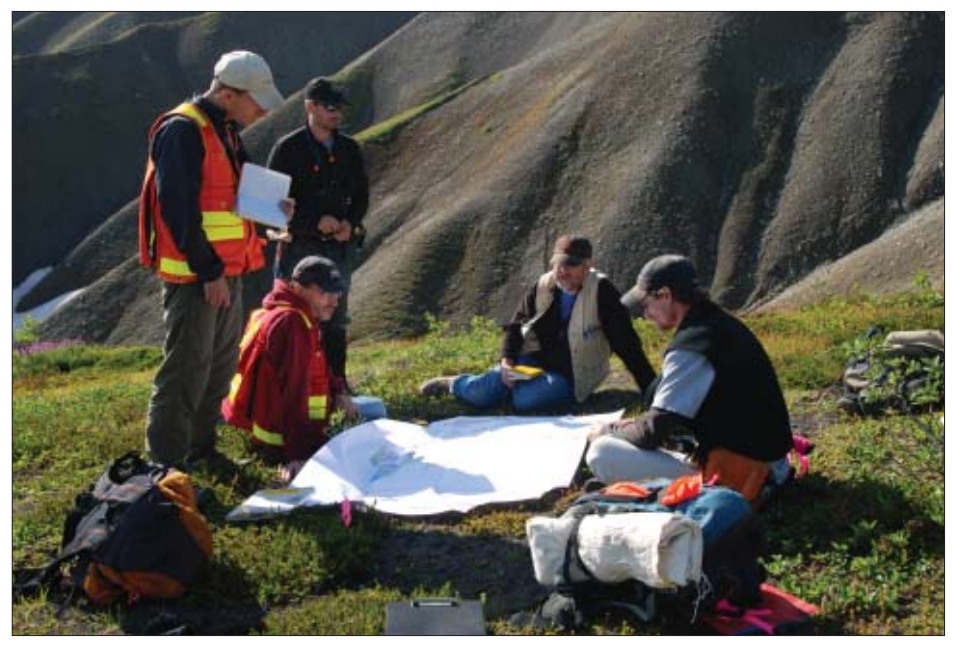
Anchor Point. This area includes exposures of rocks known to have sourced most, if not all, of the oil and some gas produced from fields in upper Cook Inlet. Information obtained from these stratigraphic units provides important keys to understanding the remaining petroleum potential in the basin.

DGGS is collaborating with the Alaska Division of Oil and Gas on a study of the potential for deep rock formations to sequester $\mathrm{CO}_{2}$. DGGS is using publicly available coal data and existing coal mapping to produce a derivative map showing the distribution of deep coal seams that are available for sequestration.

The Statewide Energy Resource Assessment program also is collecting new coal quality and stratigraphic data and working to implement a comprehensive statewide coal resource data file as part of an integrated DGGS geologic data management system.

DGGS is participating in a multi-agency effort to inventory Alaska's energy resources. This project includes development of a user-friendly, web-based interactive map to display the location, type, and, where applicable, a risk-weighted quantity estimate of energy resources available in a given area or at a specific site. In addition to this effort, DGGS is currently reviewing available information on potential geology-based energy resources for use by rural communities. This work will summarize available relevant information, identify areas of the state where additional information is needed to better understand the actual resource potential, and will be incorporated into the web-based interactive map. The reporting function for this project was recently transferred to the Alaska Energy Authority.

The numerous elements of the Statewide Energy Resource Assessment program are financed from a mixture

of funding sources: General Fund, Industry Receipts, Federal Receipts, and Capital Improvement Project funding.

\section{OBJECTIVES}

1. Encourage active private-sector oil and gas exploration on the North Slope outside the Prudhoe Bay-Kuparuk field areas.

2. Collect new geologic data to stimulate renewed, successful exploration for hydrocarbons in the Cook Inlet Basin.

3. Provide a map showing the distribution of deep coal seams potentially available to sequester $\mathrm{CO}_{2}$.

4. Provide DNR, other state agencies, and the public with authoritative information relating to the energy resources of the state so that rational policy and investment decisions can be made.

\section{FY2010 ENERGY RESOURCES PROJECTS}

Detailed project summaries for the following energy resources projects appear in the section Project Summaries-FY2010:

Brooks Range foothills \& North Slope program - p. 33

Geologic mapping in the Sagavanirktok River area (STATEMAP project) - p. 34

Cook Inlet geology \& hydrocarbon potential - p. 35

Geologic mapping in the Tyonek-Capps Glacier area - p. 36

Refining estimates for Alaska coal seam carbon sequestration - p. 37

Alaska coal database - National Coal Resource Database System - p. 38 
In addition to the above projects, the Energy Resources section performs the following tasks:

- Provide written evaluations of mineable coal potential for lease areas in response to requests from Division of Mining, Land and Water.
- Respond to verbal requests from other state agencies, federal agencies, industry, local government, and the public for information on energy-related geologic framework and oil, gas, and coal resource data.

\section{MINERAL RESOURCES}

The minerals industry has been a significant and steadfast partner in the economic well-being of Alaska since the late 1800s. In more recent times, global demand for

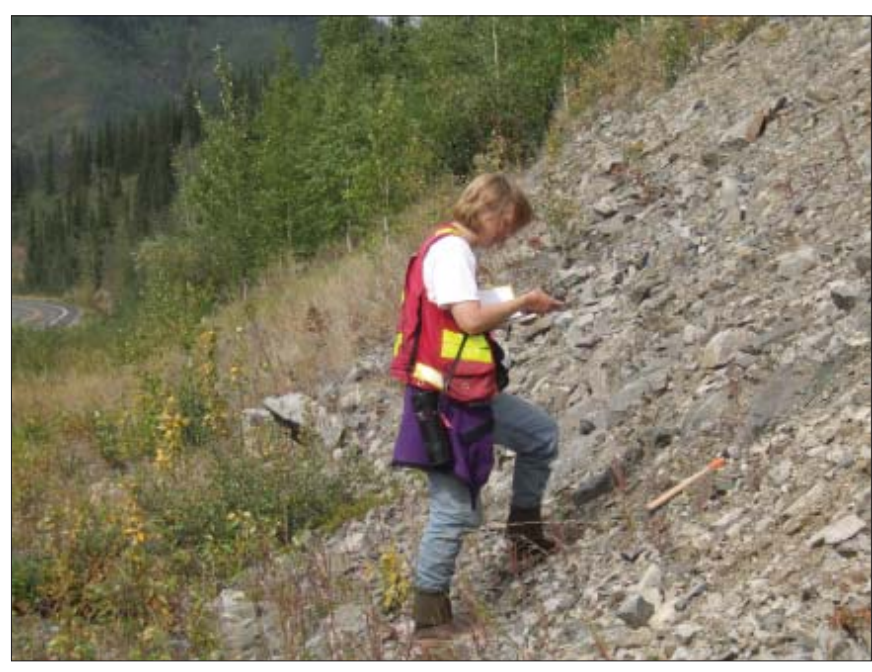

designed to produce, on a prioritized schedule, the critical new surveys and reports needed to sustain Alaska's mineral industry investments and provide management agencies with information needed to formulate rational management policy.

The Mineral Resources section also shares responsibilities with the Geologic Communications Section in the Division-wide task of implementing a publicly accessible, comprehensive, online computerized Alaska geologic information database through implementation of the Minerals Data and Information Rescue in Alaska (MDIRA) program.

The numerous elements of the Mineral Resources section are financed from a mixture of funding sources: General Fund base budget, Capital Improvement Project funding, Federal Receipts, and Program Receipts.

strategic minerals is at an all-time high and Alaska's mineral reserves will play a significant role in helping to meet that rising demand. The mineral industry, however, has historically been reluctant to commit significant company resources to exploration without sufficient understanding of the geologic framework of their areas of interest. For this reason, and to support responsible stewardship of Alaska's mineral endowment, DGGS conducts geological and geophysical surveys of the most prospective Alaska lands that are open to mineral and other geologic resource development.

Alaska has an accessible state land endowment of more than 100 million acres, much of it selected under the Statehood Act because of perceived potential to host mineral wealth. Currently the overwhelming majority of these lands are not geologically or geophysically surveyed at a sufficiently detailed level, nor with the focus needed, to optimize mineral discovery and development. Recently, a DNR/DGGS program of integrated geological and geophysical mapping has been effective in attracting new private-sector mineral investment capital to Alaska. Projects of the Mineral Resources section are

\section{OBJECTIVES}

1. Catalyze increased mineral resource exploration in Alaska's mining districts.

2. Provide DNR, other state agencies, and the public with unbiased, authoritative information on the geologic framework and mineral resources of the state so that rational land policy and investment decisions can be made.

3. Provide, in cooperation with the Department of Commerce, Community and Economic Development, an accurate annual statistical and descriptive summary of the status of Alaska's mineral industry.

\section{FY2010 MINERAL RESOURCES PROJECTS}

Detailed project summaries for the following Mineral Resources projects appear in the section Project Summaries-FY2010:

Airborne geophysical/geological mineral inventory program: Airborne geophysical survey of the Moran area, Melozitna mining district, central Alaska - p. 39 
Airborne geophysical/geological mineral inventory program: Bedrock geologic mapping of the Slate Creek area, Mt. Hayes Quadrangle, south-central Alaska - p. 40

Airborne geophysical/geological mineral inventory program: Geologic mapping in the eastern Bonnifield mining district, Healy and Fairbanks quadrangles, Alaska - p. 41

Airborne geophysical/geological mineral inventory program: Bedrock geologic mapping in the northern Fairbanks mining district, Circle Quadrangle, Alaska - p. 42

Airborne geophysical/geological mineral inventory program: Bedrock geologic mapping in the Council-Big Hurrah-Bluff area, Seward Peninsula, Alaska - p. 43

Bedrock geology and mineral-resource assessment along the proposed Gas Pipeline Corridor from Delta Junction to the Canada border - p. 44 Annual Alaska mineral industry report - p. 45
*Alaska geological and geophysical map index - p. 46

${ }^{*}$ Geochronologic database for Alaska - p. 47

*former MDIRA-supported project (see p. 15)

In addition to the above projects, the Mineral Resources section performs the following tasks:

- DGGS Mineral Resource geologists provide timely responses to verbal and written requests for mineral information from other state and federal agencies, local government, industry, and the general public.

- Provide authoritative briefings about the status of Alaska's mineral industry, state support for mineral ventures, and recently acquired geophysical and geological data at professional mineral industry conventions and trade shows, and in professional journals.

\section{ENGINEERING GEOLOGY}

The Engineering Geology program addresses major engineering-geology and geologic-hazard issues that affect public safety and economic well-being in developing areas of Alaska. DGGS conducts engineering-geologic mapping to determine the distribution and character of surficial deposits, their suitability for foundations, susceptibility to erosion, earthquakes and landslides, and other geologic hazards. Geologic evaluations of areas subject to major hazards like floods, earthquakes, volcanic eruptions, tsunamis, and landslides help to forecast the likelihood of future major events and the severity of hazards associated with them. In addition to General Funds, some elements of the Engineering Geology program are partially or largely financed through Federal Receipts.

In many areas, the state lacks the fundamental geologic data needed to guide the proper development and implementation of building codes, land-use zoning, right-of-way siting, and contingency planning for adverse natural hazard events. Loss of life and damage to infrastructure and buildings can be reduced through informed construction practices, land-use planning, building-code application, and emergency preparedness. However, economics and practicality dictate that mitigation measures be implemented first where risk is highest. Because hazards are not uniformly distributed, engineering-geologic and hazard maps become the first source of information about where damage is likely to be greatest and, therefore, where mitigation efforts should be concentrated. These maps are critical for emergency planning and the allocation of emergency-response resources prior to an adverse event.

The type of surficial-geologic mapping conducted for purposes of identifying geologic hazards and locating sources of construction materials is also of benefit for locating placer-mineral deposits. For this reason,

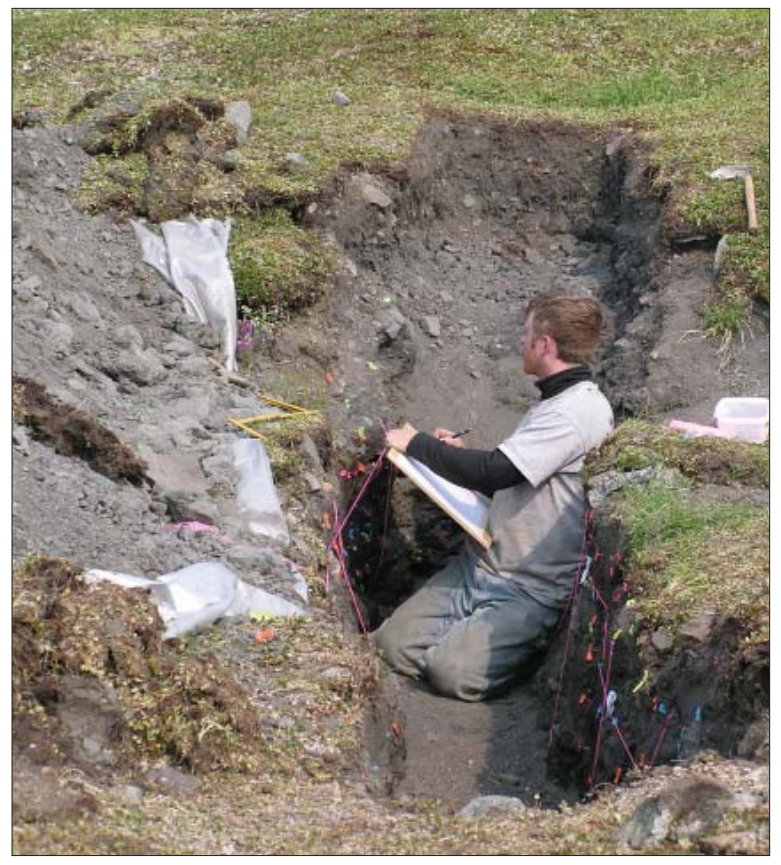


engineering-geology personnel often participate in teams with DGGS's mineral-resources geologists to map areas of interest for minerals exploration.

A major continuing program headed by the Engineering Geology section but also involving members of the Mineral Resources section is the geologic mapping and hazards evaluation of the proposed natural gas pipeline corridor from Delta Junction to the Canada border. The purpose of this multi-year project is to provide detailed geologic information of a 12-mile-wide corridor on which to base alignment decisions, engineering design, permitting, and planning for future development along the Alaska Highway. Following acquisition of high-resolution airborne geophysical data in 2006, DGGS began collecting field data from Delta Junction eastward. Field work is expected to be completed by 2010 , with final reports and maps to be published in 2011 and 2012.

A significant effort of the Engineering Geology section in the past has been in support of MapTEACH (Mapping Technology Experiences with Alaska's Cultural Heritage), a field-based geoscience outreach program for middle- and high-school students in rural Alaska that emphasizes hands-on experience with geoscience and spatial technology in conjunction with traditional activities. The project came to the end of its original $\mathrm{Na}-$ tional Science Foundation funding in April 2008 and was adopted by the University of Alaska Geography program as its flagship K-12 outreach program. DGGS continues to be involved in a limited capacity with MapTEACH activities to enhance community understanding of landscape processes and natural hazards in rural Alaska, and to foster appreciation of state-of-the-art technology tools and data sets that can be applied to informed community planning and decision making.

Major new projects starting this year have been developed in response to the overwhelming need for baseline geologic mapping and natural hazards evaluations in and near communities that are being affected by severe erosion and flooding problems, some of which are likely to be exacerbated by climate change. Thawing permafrost and possible sea level changes are also a growing concern for many Alaskan communities. DGGS recognizes the importance of reliable scientific information to help the state and its communities prepare for potential emergency situations resulting from geologic hazards, including those that are affected or amplified by climate change. DGGS will perform geologic studies to identify high-risk areas where proactive mitigation efforts will be needed and useful, as well as evaluating proposed relocation sites for communities faced with the immediate need to move to a safer location. Addition- ally, new DGGS expertise in the field of neotectonics (active faulting) will be dedicated to identifying and understanding active faults and earthquake hazards in developing areas of the state.

\section{OBJECTIVES}

1. Help mitigate risks to public safety and health by providing information on geologic hazards as they affect human activity.

2. Provide geologic information to help lower the costs of construction design and improve planning to mitigate consequences arising from hazardous natural geologic events and conditions.

3. Provide reliable engineering-geologic data for informed land-use decisions by the government and private sector.

4. Identify sources of sand, gravel, rip-rap, stone, and other geologic construction materials required to create the infrastructure, roads, and other land-based transportation corridor improvements necessary to support expanded development of natural resources and other local economic activities in Alaska.

5. Identify potential sources of placer minerals in conjunction with minerals resources mapping projects.

\section{FY2010 ENGINEERING GEOLOGY PROJECTS}

Detailed project summaries for the following Engineering Geology projects appear in the section Project Summaries-FY2010:

Alaska Coastal Management Program: Natural hazards - p. 48

Assessments of geologic hazards associated with climate change - p. 49

Geohazard evaluation and geologic mapping for coastal communities - p. 50

Geologic mapping and hazards evaluation in and near

Kivalina, northwestern Alaska - p. 51

Geology, geohazards, and resources along the proposed gas pipeline corridor, Alaska Highway, from Tetlin Junction to the Canada border - p. 52

Neotectonic mapping along the Lake Clark fault in the Tyonek area, western Cook Inlet, Alaska - p. 53

Paleoseismic studies along the Denali fault, MentastaSlana geophysical survey tract - p. 54

Quaternary fault and fold database - p. 55

Surficial geologic mapping in the Tyonek area, western Cook Inlet, Alaska - p. 56

Surficial geologic mapping of the Slate Creek area, Mt. Hayes Quadrangle, south-central Alaska - p. 57 
Surficial geology of part of the Sagavanirktok Quadrangle, North Slope, Alaska - p. 58

Tsunami inundation mapping for Alaska coastal communities - p. 59

In addition to the above projects, the Engineering Geology section performs the following tasks:

- Produce written evaluations of potential hazards in areas of oil exploration leases, land disposals, permit applications, etc., and respond to verbal requests for information from other state agencies, local government, and the general public.
- As part of the Alaska Coastal Management Program, conduct reviews of district coastal management plans, Coastal Policy Questionnaires, and consistency applications to determine compliance with the program's natural hazards standards (11 AAC 112.210).

- When appropriate, conduct post-event hazard evaluations in response to unexpected major geologic events (e.g., earthquakes and landslides), providing timely information dispersal to the public via electronic as well as traditional methods, and providing event and continuing hazard information to appropriate emergency management agencies.

\section{VOLCANOLOGY}

The Volcanology program of DGGS works as part of an interagency consortium to mitigate hazards from Alaska volcanoes. The consortium is the Alaska Volcano Observatory (AVO), formed by Memorandum of Understanding in 1988. AVO cooperators are DGGS, the U.S. Geological Survey (USGS), and the University of Alaska Fairbanks Geophysical Institute (UAF/GI). In the past, the Volcanology program has existed as a sub-program in the Engineering Geology section; the Director established Volcanology as a separate section in early 2007.

AVO studies volcanoes to increase understanding of hazards at particular volcanoes and how volcanoes work in general; monitors volcanoes using seismology, geodesy, satellite remote sensing, field studies, and local observers; and provides timely and accurate warning of increasing unrest and eruptions to emergency management agencies, other government entities, the private sector, and the public. Most Alaska volcanoes are remote from human settlements, but all underlie the heavily traveled north Pacific passenger and cargo air routes between North America and Asia; thus the aviation sector is an important recipient of AVO monitoring and reporting.

The three component agencies of AVO (DGGS, USGS, UAF/GI) each bring particular strengths to the observatory, while sharing general expertise in volcanology (see figure). Among these agencies, DGGS has the primary AVO mandate for baseline geologic mapping and the state's mandate for hazards studies. DGGS's administrative flexibility has allowed us to build and maintain the AVO website, serving a large database of descriptive material about volcanoes, providing a cutting-edge system for intra-observatory communication and data sharing, and providing notices of eruptions and unrest to users in public, private, and government sectors. The database and information dissemination tools built around the database has emerged as the most powerful such tool among volcano observatories worldwide. Particular strengths of the USGS are the federal hazards mandate and direct ties federal agencies. UAF/GI brings a research mandate and access to technological resources (such as satellite data downlink centers) beyond the financial capability of AVO. All agencies have fundamental expertise in the many disciplines that comprise volcanology.

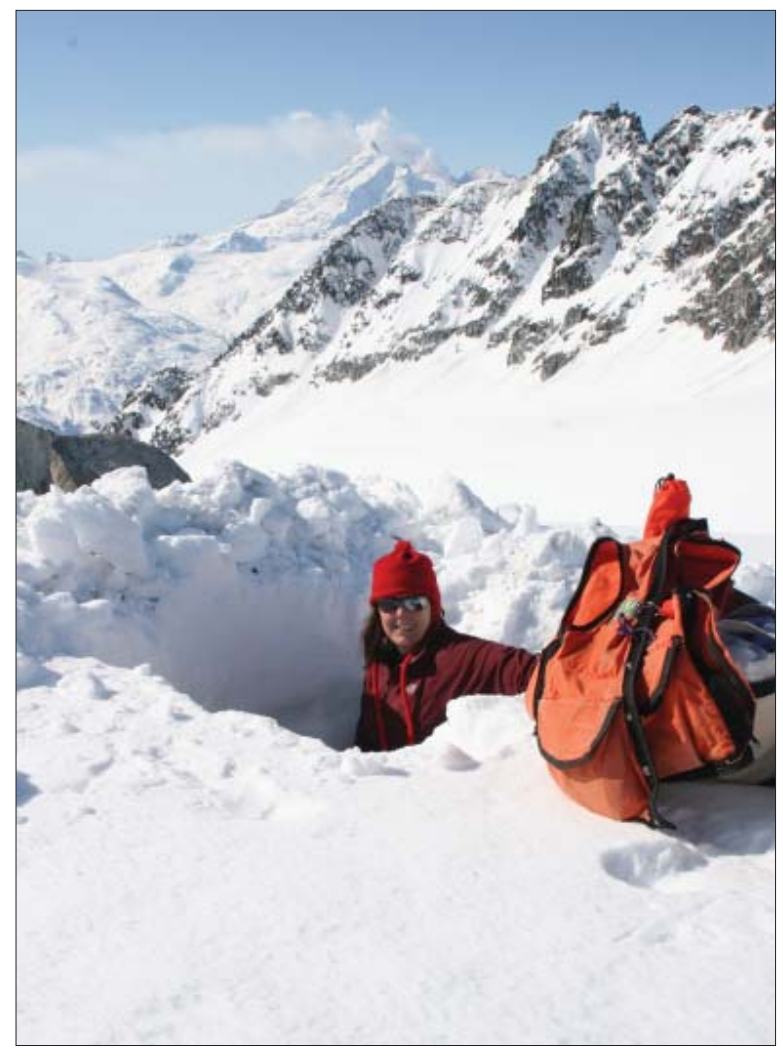


Funds for DGGS participation in AVO come from cooperative agreements with the USGS. The majority of these funds in turn come from the USGS Volcano Hazards Program base budget. In the past, the remainder has come to USGS as specially mandated congressional programs through other agencies in other departments, such as Transportation and Defense. The loss of these designated funds has negatively impacted AVO's ability to maintain volcano-monitoring networks. The continuing impact to AVO will be significant if replacement funds are not secured. The outcome of the federal budget process is unknown, and difficult to predict.

\section{OBJECTIVES}

1. Help mitigate risks to public safety and health by providing information on volcanic hazards as they affect human activity.

2. Represent the State of Alaska's interests within the multiagency Alaska Volcano Observatory.

3. Develop and maintain the Alaska Volcano Observatory website as a primary communications vehicle to deliver information about Alaska's volcanoes to the public and provide internal communications and data exchange among AVO personnel.

4. Provide comprehensive information on Alaska volcanoes, including past history and current activity, to the general public, agencies, and volcanologists worldwide.

\section{FY2010 VOLCANOLOGY PROJECTS}

Detailed project summaries for the following Volcanology projects appear in the section Project Summaries-FY2010:

Redoubt Volcano: 2009 eruption response and geologic investigations - p. 60

Chiginagak volcano: Monitoring the persistent environmental damage from the 2005 acid crater lake drainage - p. 61

Geomorphology and hydrogeology of the 2008 phreatomagmatic eruption of Okmok volcano - p. 62

Kasatochi integrated study: Response of a devastated ecosystem - p. 63

Alaska Volcano Observatory website and database - p. 64

Alaska Volcano Observatory’s Hazard Notification System (HANS) - p. 65

1,200 vents - Inventory of Quaternary volcanic vents in Alaska - p. 66

Quaternary volcanoes of southeastern Alaska - p. 67
In addition to the above projects, the Volcanology section performs the following tasks:

- Assist AVO in volcano monitoring. AVO monitors volcanoes using short-period seismometers, broadband seismometers, continuous telemetered GPS, satellite imagery, gas measurements, web cameras, and local observer reports. AVO maintains seismic networks on 27 active volcanoes (up from four in the mid-1990s, but, as of midNovember, 2009, less than the high of 31), and monitors more than 100 volcanoes twice daily by satellite. While not a primary DGGS activity, DGGS assists in volcano monitoring when needed during eruption events.

- Provide advanced GIS expertise to all component agencies in AVO. This includes producing base maps in areas where 1:63,360-scale topographic maps do not exist, retrieving and georegistering maps from discontinued map series, and producing a variety of other georegistered data products. DGGS also provides expertise in finalizing and troubleshooting GIS-based map publications using standard GIS techniques for numerous projects in all AVO component agencies.

- Provide helicopter and ship logistics. DGGS manages helicopter charter procurement for all major AVO projects, ship charters for projects that are far enough from population centers to require ship-based helicopters, and fixed-wing charter for volcanic gas measurement flights. Having all the contracting done by a single agency results in significant budgetary and logistic efficiencies.

- Perform geochemical data procurement and archiving, coordinating geochemical analyses, and maintaining the archive of those data. These data share rigid inter-project quality controls, making the combined data set a major resource for researchers and adding substantially to the value of the data from individual geologic mapping projects.

- Represent DGGS to CUSVO/NVEWS. DGGS is one of the charter members of the Consortium of U.S. Volcano Observatories (CUSVO), which provides coordination among the five volcano observatories in the United States. The National Volcano Early Warning System (NVEWS) is a major emerging initiative of CUSVO; the DGGS project leader serves on the NVEWS steering committee and chairs one of the five subpanels developing the program implementation plan.

- Provide information on geothermal resources to state and federal agencies, the private sector, and the public. 


\section{GEOLOGIC COMMUNICATIONS}

The Geologic Communications Section staff edits, designs, publishes, and disseminates technical and summary reports and maps generated by the Division's technical projects about Alaska's geologic resources and hazards. The maps and reports released through this section are the state's primary means for widely disseminating detailed information and data relating to Alaska's subsurface mineral and energy wealth, its geologic construction materials, and its geologic hazards.

These printed and/or digital format documents focus attention on Alaska's most geologically prospective and useful lands and are the authoritative geologic basis for many of the state's resource-related land-policy decisions. They also encourage geologic exploration investment leading to resource discoveries and subsequent major capital investments. Timely availability of geologic information from DGGS is a significant factor in stimulating Alaska's economy and mitigating the adverse effects of geologic hazards.

The geologic information center staff provides information to the public on a wide range of topics including mineral and energy resources, prospecting, earthquakes, volcanoes, and permafrost. The information center staff also assists customers in understanding geological and geophysical maps, and manages sales of geologic

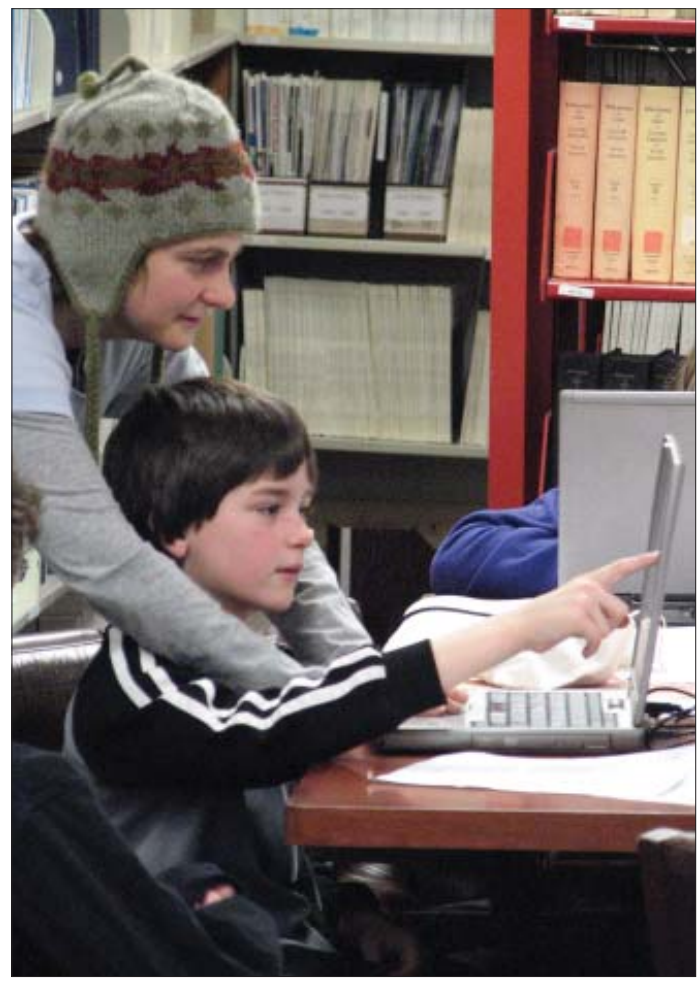

reports, maps, and digital data. Additionally, the section prepares displays and represents the division at geologic conferences and events. The section produces this annual report summarizing division activities and accomplishments; publishes twice-yearly newsletters to communicate division progress and advertise recent publications; designs, edits, and produces technical and educational geologic maps and reports in printed and digital formats; manages the DGGS library so that reports (by DGGS and other related agencies) are available for geologic staff; and participates in outreach activities such as classroom presentations, science fair judging, and helping teachers plan earth science units.

The division's Digital Geologic Database project (Geologic \& Earth Resources Information Library of Alaska - GERILA) has three primary objectives: (1) maintain this spatially referenced geologic database system in a centralized data and information architecture with networked data access for new DGGS geologic data; (2) create a functional, map-based on-line system that allows the public to find and identify the type and geographic locations of geologic data available from DGGS and then view or download the selected data (www.dggs. dnr.state.ak.us/pubs/); and (3) cooperatively integrate DGGS data with data from other agencies through a multi-agency website (www.akgeology.info/).

The Geologic Communications section provides computer hardware and software and GIS service and support to DGGS staff and streamlines information delivery to the public. The section established the division's website and began extensive use of the Internet in FY98 to increase the availability of the Division's information and to provide state and worldwide access to the Alaska's geologic information. These efforts developed into a major project to establish, maintain, and enhance a state-federal multi-agency Internet-accessible Alaska geologic database management system. Federal funding supported an extensive effort to scan, convert to digital format, and post the entire pre-digital DGGS collection of publications on our website. The U.S. Geological Survey provided additional funds to do the same for all pre-digital Alaska-related USGS publications and make them available via the DGGS website. Future additions include former U.S. Bureau of Mines publications (now part of Bureau of Land Management).

The Geologic Communications Section is supported by the General Fund, Program Receipts from publication sales, and Federal Receipts. 


\section{OBJECTIVES}

1. Disseminate new, accurate, unbiased, Divisiongenerated data on Alaska's geology, as well as selected data from other sources, to DNR policy and regulatory groups, to the public at large, and to all other interested parties, within one year of its acquisition.

2. Preserve and manage the data and knowledge generated by the Division's special and ongoing projects in an organized, readily retrievable, and reproducible form consistent with pertinent professional standards.

3. Focus public awareness on Alaska's most prospective mineral and energy lands.

\section{FY2010 GEOLOGIC COMMUNICATIONS PROJECTS}

Detailed project summaries for the following Geologic Communications projects appear in the section Project Summaries-FY2010:

Digital geologic database project- p. 68

*Geologic Materials Center online sample catalog - p. 69

Website development - p. 70

Publications and outreach project - p. 71

National Geological and Geophysical Data Preservation Program (NGGDPP) - p. 72

GIS-IT infrastructure project - p. 73

* former MDIRA-supported project (see p. 15)

\section{GEOLOGIC MATERIALS CENTER}

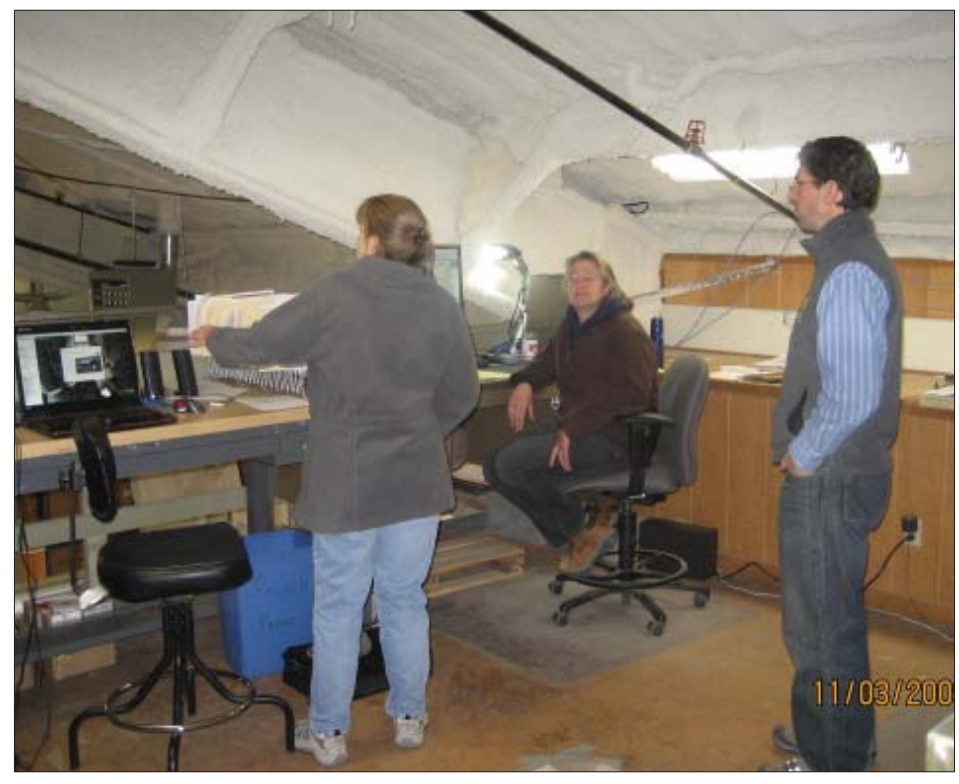

all new samples, sample preparation and analyses, sample logs, and data logs, and occasionally donates storage containers and/or shelving.

The holdings of the GMC are a continually growing asset that is compounding in value over time at little cost to the state. The GMC facility is staffed by two Division geologists, a Natural Resource Technician, a contract geologist, four student interns, and several volunteers. The GMC has formal cooperative agreements with the U.S. Geological Survey, the U.S. Minerals Management Service, and U.S. Bureau of Land Management to house and control their geologic materials from Alaska. A voluntary 14-member board advises the curator and DGGS on matters pertaining to the GMC.
The Alaska Geologic Materials Center (GMC) in Eagle River archives and provides public access to non-proprietary oil, gas, and coal drill cores and drill-cutting samples, rock cores from mineral properties, and processed ore, oil, gas, coal, and source-rock samples. These samples are used by government and private-sector geoscientists to improve the odds of finding new oil, gas, and mineral deposits that will maintain the flow of state revenues and provide in-state employment. The Geologic Materials Center Project is supported by the General Fund budget and in-kind contributions from industry. Additional financial support is received annually from the Alaska Oil \& Gas Conservation Commission. The private sector contributes the cost of delivering
With federal funding and through a Reimbursable Services Agreement with the Department of Transportation \& Public Facilities, DGGS recently completed a concept study for construction of a new materials center to replace the existing GMC. The sample collection long ago exceeded available warehouse space, with the overflow now occupying 60 unheated tractor-trailer type portable storage containers. Limited space and unsuitable site conditions preclude significant expansion at the existing site in Eagle River. DGGS is considering a proposed new site on state land south of Eagle River and is now looking for sources of funding to finance the project. The concept study report is available on the GMC web page. In 2007, DGGS used information from this 
report to develop a brochure explaining the functions and services of the GMC and the need for an upgraded facility. The brochure is presented in the appendix of this report. DGGS has begun phase I of the design work for a new facility with support of state Capital Improvement Project (CIP) funds. This work is being conducted by a private engineering firm contracted by the Department of Transportation \& Public Facilities.

\section{OBJECTIVES}

1. Encourage responsible resource development and in-state employment opportunities by increasing accessibility to representative geologic samples and information pertaining to oil, gas, and mineral exploration.

2. Advance the knowledge of the geology and resources in Alaska's structural basins favorable for oil or gas discovery.

3. Advance the knowledge of Alaska's mineral potential by making available representative samples of ores and drill cores from mineral deposits throughout the state.

A detailed project description for the Geologic Materials Center appears in the section Project Summaries-FY2010 (p. 74).

\section{ADMINISTRATIVE SERVICES}

The Administrative Services group provides financial control and administrative support for all other projects in the Geological Development component including: securing lowest costs for goods and services; maintaining, and when necessary, procuring vehicles for field work; coordinating travel arrangements and appropriate paperwork to minimize travel expenses and field party subsistence costs; administering and monitoring grants and contracts; tracking and reporting project expenditures to ensure cost containment within budget for all projects; mail/courier services; assistance in personnel matters; and any other support necessary to increase efficiency or savings in acquiring and disseminating knowledge of the geology of Alaska.

\section{OBJECTIVE}

1. Facilitate the efficient administration of DGGS programs and projects.
- Minimize the cost of transportation to and from the field by coordinating personnel travel and supply shipments.

- Coordinate Division vehicle use to minimize requests for reimbursement for personal vehicle mileage.

- Make travel arrangements and complete travel authorizations to ensure use of the lowest-cost travel options.

- Assist staff with personnel matters; inform staff about changes in personnel rules or benefits and ensure that all personnel paperwork complies with applicable rules and regulations. Estimate future personnel salaries and benefits to assist management in making human resource decisions necessary to efficiently accomplish the division's mission.

\section{Tasks}

- Monitor grants and contracts (Federal, Interagency, and Program Receipts) to ensure deliverables are produced on schedule and within budget; ensure expenses are timely and properly billed against grants and contracts and receipts are collected promptly.

- Provide accurate, timely reporting of project expenditures and current balances; encourage prudent money management.

- Provide accurate, timely processing of employee timesheets, invoices, procurement records, and other documentation required by the State; ensure strict adherence to State archiving requirements.

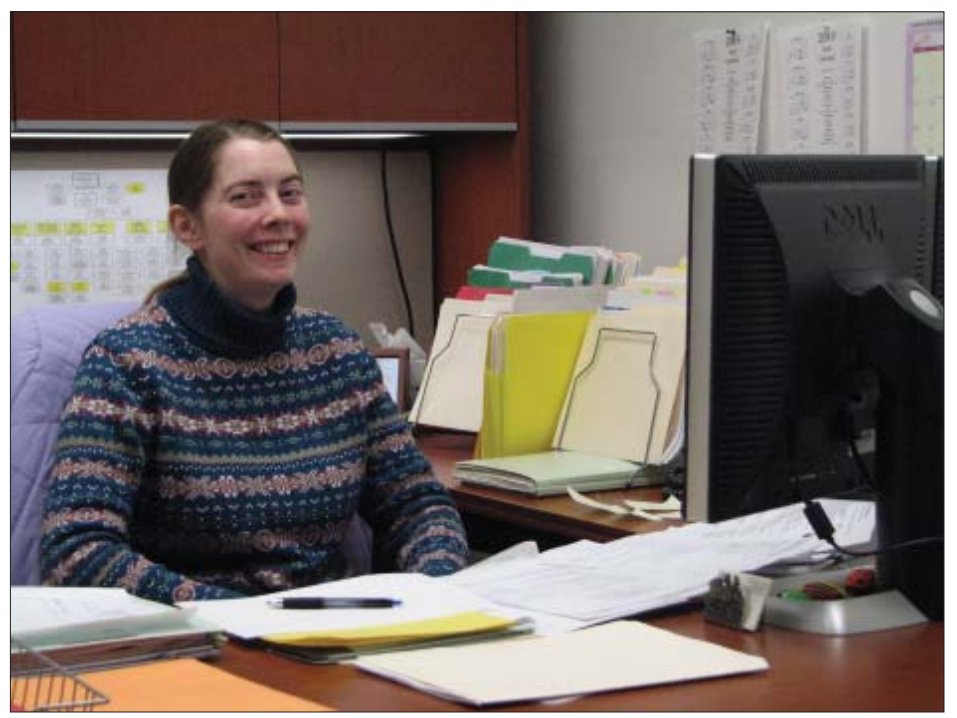




\section{EMPLOYEE HIGHLIGHTS}

\section{WELCOME}

Trystan HerRiotT joined DGGS as a geologist in May 2009. He originally is from Texas, but spent the bulk of his formative years in California and, upon graduating high school, attended the University of California at Santa Barbara. Trystan earned his B.S. in Geological Sciences in 2005 and continued at UC Santa Barbara to

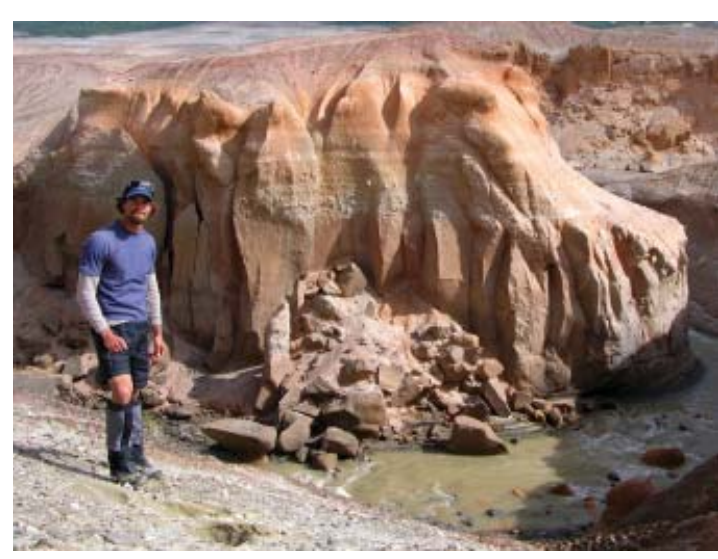
pursue a master's degree. His master's thesis study area lies in a relatively remote and rugged region of the central Chilean Andes where fossil mammal-bearing volcaniclastic rocks of Miocene age crop out near the modern volcanic arc. It turned out Trystan was better at finding kilometer-scale folds than fossil mammals, although he enjoyed looking for fossils as he mapped the geology. His research in Chile primarily focused on the structural, stratigraphic, and sedimentologic histories of the region in an effort to provide a geologic framework for the collaborative paleontologic studies and to further constrain the timing of tectonic evolution within the central Chilean Andes during middle to late Cenozoic time. Concurrent with his master's studies, Trystan also worked with scientists at the U.S. Geological Survey's Cascades Volcano Observatory, creating a chronologic series of photogeologic maps for the 2004-2008 lava dome eruption at Mount St. Helens.

Since first visiting the 49th state in 1998, Trystan has appreciated the awesomeness of Alaska. After half a dozen or so trips to Alaska in the ensuing years, he moved to Fairbanks in 2006 to pursue his career as a geologist. Working in DGGS's Energy Resources section is a great fit for Trystan, who seems to have a particular affinity for conducting geologic research along the vast reaches of the American Cordillera.

When Trystan is not working he enjoys landscape photography, backpacking, hunting, and river running, as well as reading extensively about those subjects and many others. During periods with winter temperatures warmer than $30^{\circ} \mathrm{F}$ below zero you may find Trystan out running, skiing, or walking along the trails in Goldstream Valley where he lives with his girlfriend, Taryn; if it's much colder, you are more likely to find him near the woodburning stove listening to an audiobook.

RichaRD KoEHLER started as the new neotectonic geologist with the Engineering Geology section of DGGS in June 2009. Upon arrival, he was immediately deployed to the field to investigate earthquake geology along the Denali fault.

Rich grew up in northern California where he developed a love of the outdoors exploring the Coast Range mountains. His interest in earthquakes began as an undergraduate at the University of California, Santa Cruz, when he was "knocked off his feet" by intense seismic waves generated by the $1989 \mathrm{M}=7.1$ Loma Prieta earthquake. After college, he mapped caves for the summer on Prince of Wales and Dall islands, Alaska, and rode his bicycle back to California. At Humboldt State University, Rich earned a Master's degree in geology studying faults associated with the Mendocino Triple Junction, tsunami deposits, fluvial and marine terraces, and soil geomorphology. For five years, he worked for William Lettis \& Associates, Inc., where he conducted earthquake and geologic hazard assessments for large infrastructure projects related to water resources, nuclear power plants, and crude oil pipelines, and became a registered geologist with the

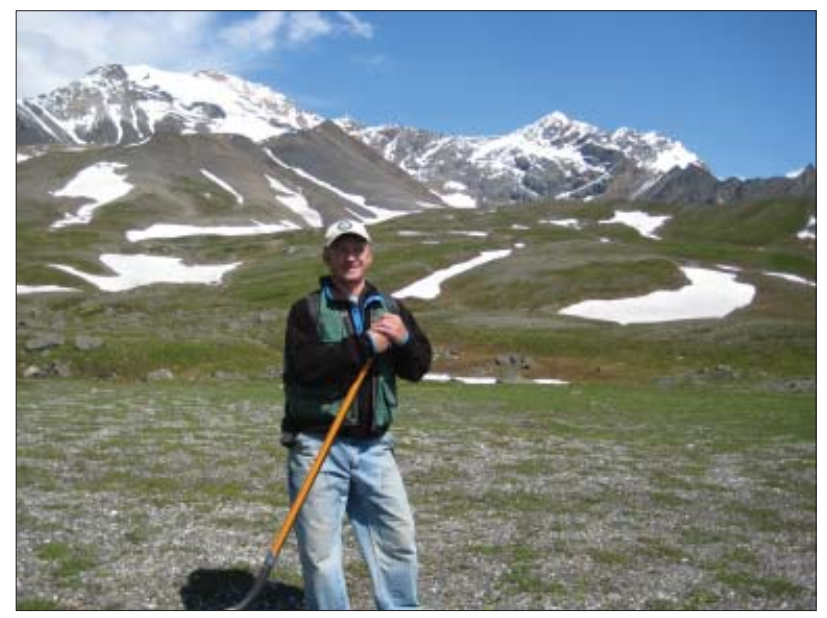


state of California. Rich's doctorate research at the University of Nevada, Reno, focused on the paleoseismology of rangefront faults along U.S. Highway 50 within the Basin and Range Province.

Rich has conducted numerous paleoseismic investigations funded by the U.S. Geological Survey's National Earthquake Hazards Reduction Program (NEHRP), including the San Andreas, Hayward, Calaveras, Green Valley, San Gregorio, and Little Salmon faults in northern California, the Northern Tijeras-Canoncito Fault System, Central New Mexico, and the Seattle, Utsalady Point, and Tacoma faults, Puget Sound, Washington. His international experience includes projects in Turkey, Taiwan, Jamaica, and Guatemala.

After the 2009 field season, Rich returned briefly to Reno to lead the Pacific Cell Friends of the Pleistocene field trip and move his family to Fairbanks. He was surprised to find out that Fairbanks is even dryer than Reno. Aside from playing in the dirt, Rich enjoys flyfishing, snowboarding, and mountain biking.

GABRIEL WOLKEN began working with the Engineering Geology section as DGGS's climate change hazards geologist in November 2009. Gabriel has always had a strong affinity to ice, rock, and dirt and an intense curiosity about how these things change with changes in climate.

Gabriel's background is quite diverse and his work has led him to a number of (mostly cold!) locations around the globe. In addition to working at a zoo, an environmental laboratory, and a few universities, he received a BSc. from Creighton University (Environmental Science/Meteorology), a MSc. from the University of Wyoming (Glaciology/Geomorphology); and a Ph.D. from the University of Alberta (Glacial Geomorphology/Climatology). His doctoral work involved using optical remote sensing and field techniques to map and interpret geomorphic features in the Canadian High Arctic, relating to the former extent of Neoglacial terrestrial ice masses, for the purpose of quantifying post-Little Ice Age ice reduction and the impact of early twentieth century warming in the Canadian High Arctic. Before joining DGGS, Gabriel spent three years as a Postdoctoral Research Fellow in the Department of Earth and Atmospheric Sciences at the University of Alberta, Edmonton, Alberta. Here he was a member of the Arctic and Alpine Research group and developed optical and microwave remote sensing techniques combined with in situ data to investigate snow-glacier-climate interactions on pan-Arctic terrestrial ice masses.

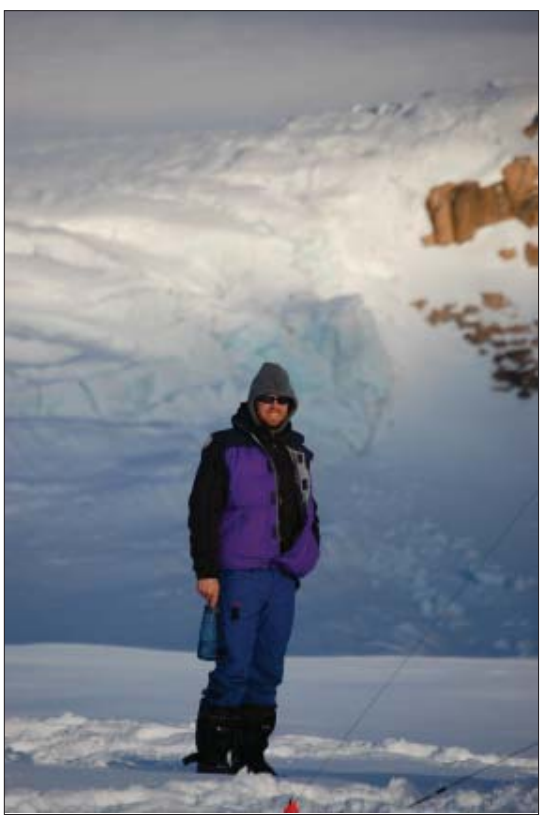
Gabriel has developed a number of international collaborations and continues to be involved in the Arctic Council's project on changes in the Arctic cryosphere (SWIPA - Snow Water Ice and Permafrost in the Arctic).

When not working on ice, rock, and dirt, Gabriel enjoys a variety of muscle-powered activities on ice, rock, and dirt. Clearly he is in the right place!

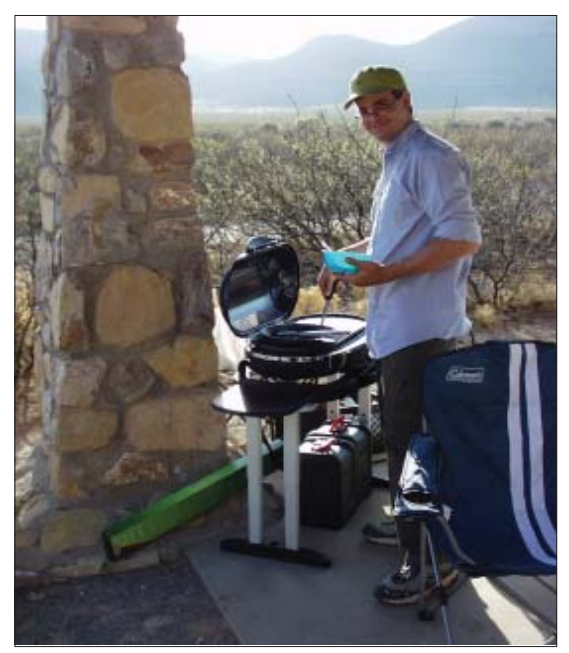

Brent ELLiOTT started working as a Geologist for DGGS at the beginning of 2010. He grew up in the hill country of south-central Texas before attending Beloit College, Wisconsin, and spending a year abroad at St. Petersburg State University, Russia, as part of a total immersion exchange program. After earning his baccalaureate degree in Geology and Russian Language, he attended the University of Helsinki, Finland, for his M.Sc. and Ph.D. in Geology and Mineralogy. Brent has taught a variety of lower- and upper-level geology courses as a professor at the University of North Alabama and Midwestern State University (Texas), before making his way to the DGGS office.

Brent's research interests are in all areas of geochemistry, mineralogy, petrology, structural geology, and tectonics, and have included mapping and structural evolution of the Wawa and Quetico Terrains of southern Ontario; crustal evolution of Svecofennian orogeny and petrogenesis of granitoids and related rocks across central and southern Finland; experi- 
mental petrology of anorogenic and rift-related rocks and associated textures; structural geology and petrology of migmatitic rocks in the Baltic Shield; and Cenozoic volcanic and intrusive rocks of southwestern Texas.

When he is not at work, Brent likes to work out, jog, ski, hike, play sports (volleyball, soccer, basketball, football, etc.), hunt, fish, shoot, pick berries, pick mushrooms, garden (especially hot peppers), barbecue (Texas or southern style, naturally), cook, bake, read, and watch sports (Go, Cowboys!).

\section{WELCOME BACK}

KEN PAPP began working for DGGS in Fairbanks as a temporary Geologist and metadata technician with the Geologic Communications section in January 2005. Soon after, he accepted a recently vacated permanent Geologist position and worked as a metadata specialist/programmer for the next $3 \frac{1}{2}$ years. Ken and his wife, Kristin, then moved to Anchorage where he worked for the Alaska Energy Authority as a program manager, establishing the Alaska Energy Data Inventory. He recently returned to DGGS in July 2009, after accepting the position of Curator at DGGS's Alaska Geologic Materials Center (GMC) in Eagle River.

Ken grew up in northeastern Ohio, but has lived in Alaska since 1999. He earned his B.S. in Geology from the University of Cincinnati, and his M.S. in Geology (Volcanology

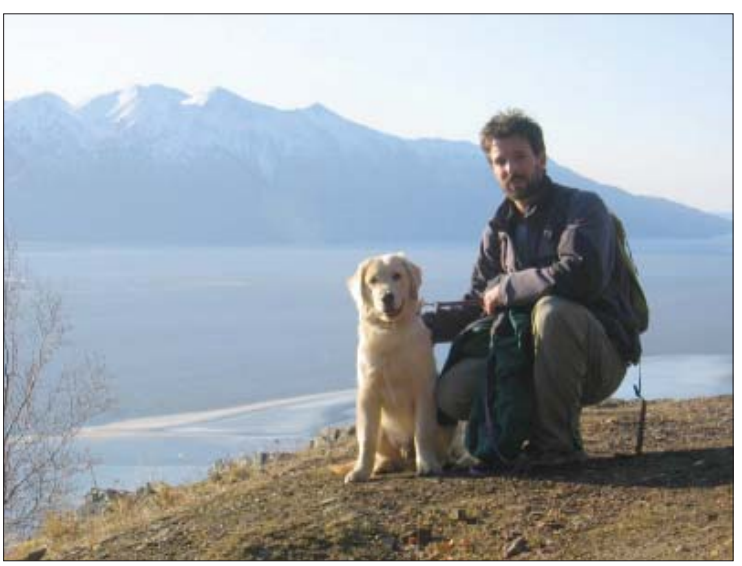
and Remote Sensing) from the University of Alaska Fairbanks. There, Ken worked for the Alaska Volcano Observatory and played an active role in the operational satellite monitoring of active North Pacific volcanoes, utilizing satellite data, eruption-detection algorithms and image-processing software. He specifically investigated the interaction between volcanic ash cloud distribution and wind climatology in the north Pacific region and helped provide airborne ash-hazard mitigation information to the airlines. His Alaska field experience includes several seasons on Mt. Cleveland volcano, Okmok volcano, and in Katmai National Park, Valley of Ten Thousand Smokes.

At the GMC, Ken works with full-time employees Jean Riordan and Kurt Johnson and several student interns, contractors, and volunteers, to oversee the archiving, inventorying, and preservation of the state's geologic sample collection, as well as making the samples available for examination by the public. When not in the office, Ken is often traversing the Alaska countryside with Kristin and their two dogs, playing soccer, drumming, biking, skiing, running, salmon fishing, cooking, watching movies, reading everything, and listening to techie/geeky podcasts.

\section{$\sim \sim$ MORE THAN 25 YEARS OF SERVICE}

\section{Alfred "Fred" Sturmann was born and raised in Austria. While studying electronics and electrotechnics at a technical school there, he discovered that geology is what he really likes. He focused the rest of his studies on this field, especially the geol- ogy of the Pleistocene epoch.}

Alfred immigrated to the USA in 1980 with his wife, Erna, and they made Fairbanks their home in 1981. They have a son, Matthew.

Alfred was hired by Fluor Co. in 1981 for the gas line project. He worked in the engineering section on general engineering designs and survey mapping. After the gas

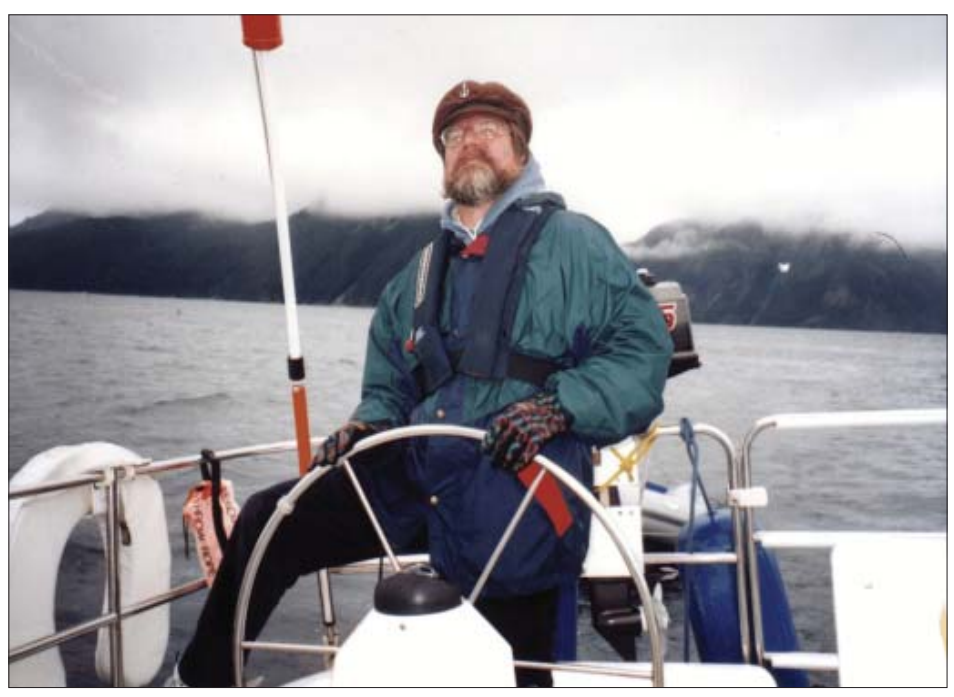


line project ended in 1982, he accepted a temporary position at the City of Fairbanks, again performing survey mapping.

In September 1982, Alfred entered State service at DGGS. He attended UAF between 1984 and 1987.

At DGGS, Alfred created mining claim maps and, later, full-color geologic maps and report illustrations. Since 1990, he has been involved with implementation of Geographic Information Systems (GIS) at DGGS and integrating project data into GIS format. Alfred produced and published DGGS's first fully digital geologic map in 1993.

Alfred has won one national and 12 statewide awards for cartographic design.

He and Erna like to sail their small sailboat or go on extended kayaking tours. They like to hike and ski, and enjoy camping in the mountains. Alfred is also a fine woodworker and enjoys making furniture of the Arts \& Crafts period.

\section{$\sim \sim$ GOODBYE}

JOHN REEDER retired in June 2009 after serving 22 years as curator of the GMC. Dr. Reeder's passion for geology, teaching, and sharing his knowledge will be greatly missed. The DGGS and GMC staff thank John for his many years of dedication and hard work. John still often works several hours a week as a volunteer at the GMC

John was born and raised in Palmer, Alaska. He is one of few Alaskans who can say he attended the same school his mother did. After graduating high school in 1968, he continued his education at the University of Idaho, earning a B.S. in Geological Engineering. John went on to earn an M.S. in Geology (1974), an M.S. in Geophysics (1983), and a Ph.D. in Geology (1981) at Stanford University. His fields of specialty are general and regional geology, regional tectonics, neotectonics, surficial geomorphic processes especially in tectonically active areas, recent geochronology of surficial earth processes, volcanology, physical crustal processes and process modeling, seismology, and natural hazards.

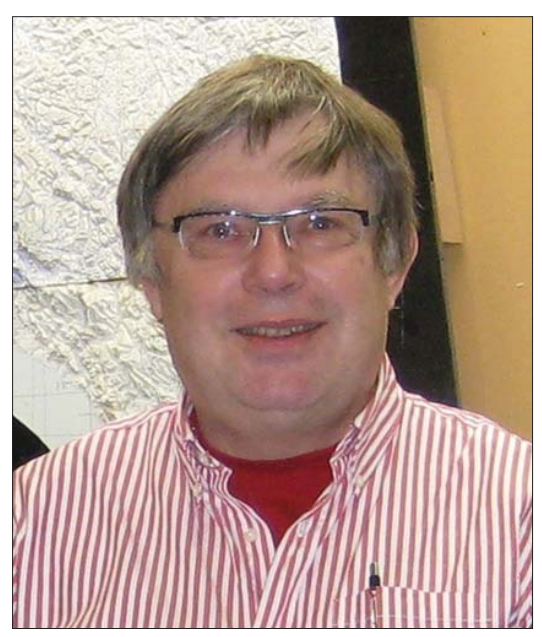

John started working for DGGS in 1979. In 1987 he moved from the Anchorage office to become the curator of the Geologic Materials Center in Eagle River. John has been instrumental in receiving and archiving many thousands of samples, mostly from oil \& gas and mineral-exploration companies, for the benefit of future exploration projects

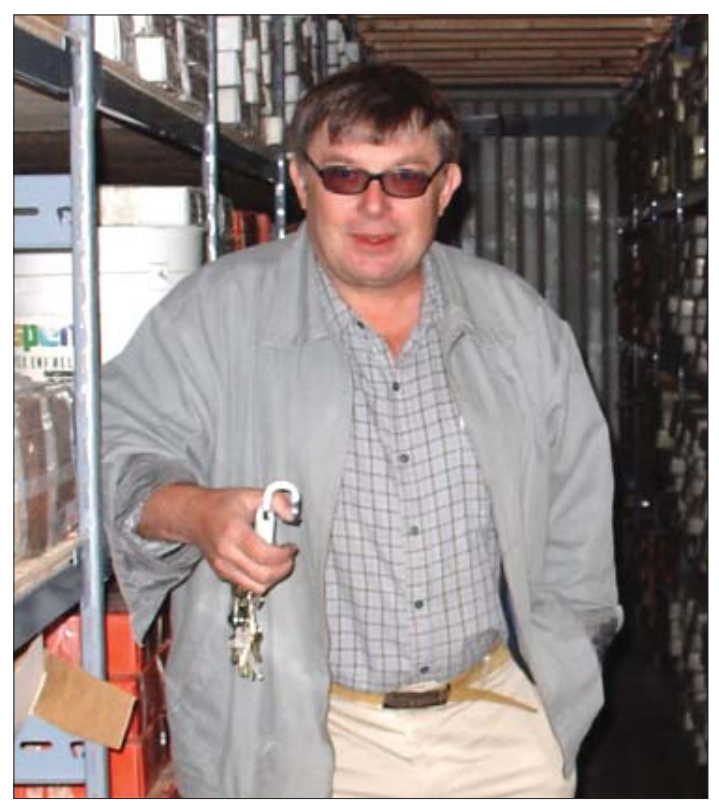
and resource management.

John and his wife, Rina, own a historial home in Venice, Italy, where they are both residents. 
After nearly 27 years of service to the State of Alaska, ROCKY REIFENSTUHL recently retired from the Alaska Division of Geological \& Geophysical Surveys (DGGS). Rocky's geologic pursuits (as well as his adventuresome spirit) took him to nearly every corner of the state, many times on a bike or walking. Rocky's publication record is impressive, and if one were to conduct a quick search of the DGGS online publications catalog, 94 publications with him as either first author or a contributing author would be returned. These publications include mineral- and energy-related projects. This is testimony to a versatile geologist and a very productive career! Over the next few months Rocky plans to revise a report on the Kemik Sandstone, originally prepared for another governmental agency more than a decade ago, for publication as a DGGS report. So the number of reports with his name on them will soon jump to 95 . Rocky and his spouse, Gail, plan to remain in the Fairbanks area to enjoy the new, very unique "green" home they recently completed. Congratulations, Rocky, for a long and productive career of service to the State of Alaska and Alaska's geological community!

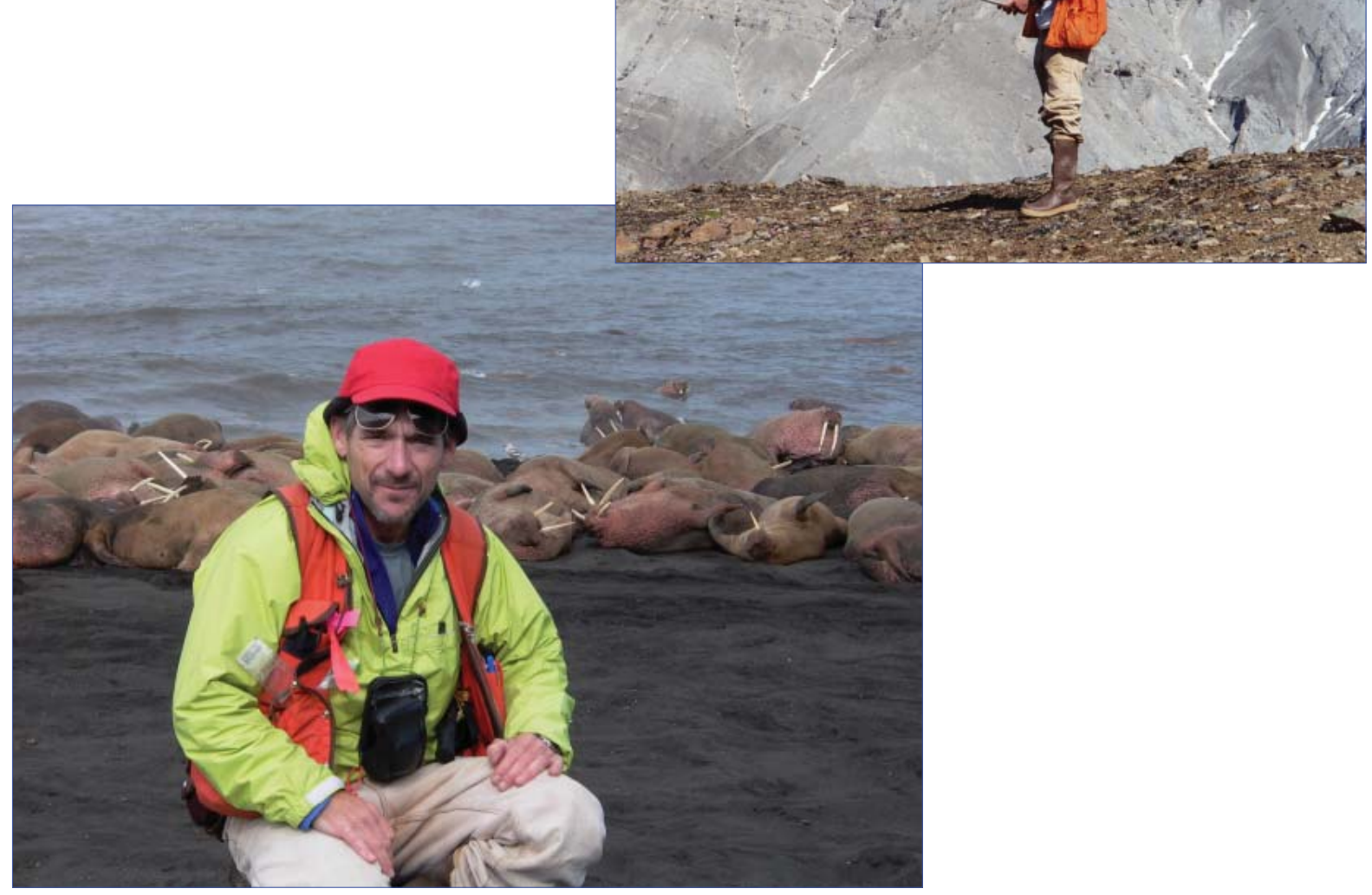




\section{PROJECT SUMMARIES-FY2010}

Alaska faces the challenge of growing a healthy economy from its natural resources while protecting an environmental legacy that is the envy of many. The Department of Natural Resources' Division of Geological \& Geophysical Surveys is an integral partner in the team of state agencies that strive to meet this challenge. The output from our projects provides the fundamental earth-science information required to guide critical policy decisions, encourage exploration investment, mitigate the effects of geologic hazards, and improve the quality of life for all Alaskans.

The overviews of the following 42 projects that DGGS is pursuing in FY2010 span the scope of our legislative mission statement.

Each of these projects is making a positive difference for Alaska. Many are implemented through various cooperative agreements with other state and federal agencies, universities, in-house project teams, and contracts. We leverage state General Funds through these arrange-ments so that the Division's work provides the greatest possible benefit from the public's investment.

\section{ENERGY RESOURCES}

Brooks Range foothills \& North Slope program ……..................................................... 33

Geologic mapping in the Sagavanirktok River area (STATEMAP project)........................ 34

Cook Inlet geology \& hydrocarbon potential ............................................................... 35

Geologic mapping in the Tyonek-Capps Glacier area ..................................................... 36

Refining estimates for Alaska coal seam carbon sequestration ...................................... 37

Alaska coal database - National Coal Resource Database System ...................................... 38

\section{Mineral Resources}

Airborne geophysical/geological mineral inventory program: Airborne geophysical survey of the Moran area, Melozitna mining district, central Alaska ......

Airborne geophysical/geological mineral inventory program: Bedrock geologic mapping of the Slate Creek area, Mt. Hayes Quadrangle, south-central Alaska ........................... 40

Airborne geophysical/geological mineral inventory program: Geologic mapping in the eastern Bonnifield mining district, Healy and Fairbanks quadrangles, Alaska.............. 41

Airborne geophysical/geological mineral inventory program: Bedrock geologic mapping in the northern Fairbanks mining district, Circle Quadrangle, Alaska........................... 42

Airborne geophysical/geological mineral inventory program: Bedrock geologic mapping in the Council-Big Hurrah-Bluff area, Seward Peninsula, Alaska................................ 43

Bedrock geology and mineral-resource assessment along the proposed Gas Pipeline Corridor from Delta Junction to the Canada border..................................................... 44

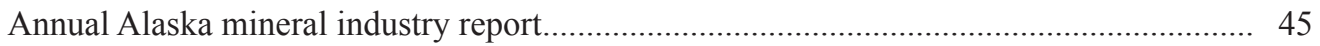

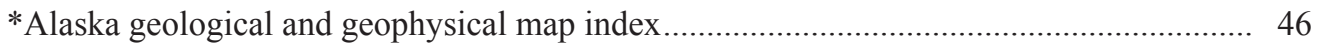

*Geochronologic database for Alaska .......................................................................... 47

\section{ENGINEERING GEOLOGY}

Alaska Coastal Management Program: Natural hazards 48

Assessments of geologic hazards associated with climate change...................................... 49

Geohazard evaluation and geologic mapping for coastal communities ........................... 50

Geologic mapping and hazards evaluation in and near Kivalina, northwestern Alaska........ 51

Geology, geohazards, and resources along the proposed gas pipeline corridor, Alaska

Highway, from Tetlin Junction to the Canada border 52

\footnotetext{
*MDIRA-supported project (see p. 15)
} 
Neotectonic mapping along the Lake Clark fault in the Tyonek area, western Cook Inlet, Alaska.

Paleoseismic studies along the Denali fault, Mentasta-Slana geophysical survey tract...... 54

Quaternary fault and fold database ................................................................................ 55

Surficial geologic mapping in the Tyonek area, western Cook Inlet, Alaska ....................... 56

Surficial geologic mapping of the Slate Creek area, Mt. Hayes Quadrangle, south-central

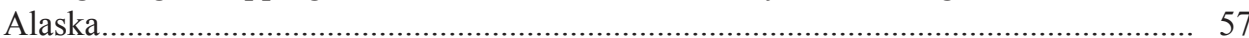

Surficial geology of part of the Sagavanirktok Quadrangle, North Slope, Alaska............... 58

Tsunami inundation mapping for Alaska coastal communities .......................................... 59

\section{VOLCANOLOGY}

Redoubt Volcano: 2009 eruption response and geologic investigations

Chiginagak volcano: Monitoring the persistent environmental damage from the 2005 acid crater lake drainage

Geomorphology and hydrogeology of the 2008 phreatomagmatic eruption of Okmok

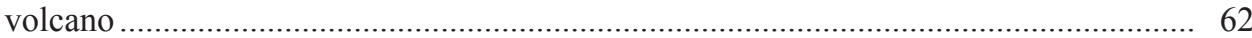

Kasatochi integrated study: Response of a devastated ecosystem ..................................... 63

Alaska Volcano Observatory website and database.......................................................... 64

Alaska Volcano Observatory's Hazard Notification System (HANS)................................. 65

1,200 vents —-Inventory of Quaternary volcanic vents in Alaska ......................................... 66

Quaternary volcanoes of southeastern Alaska .................................................................... 67

\section{Geologic Communications}

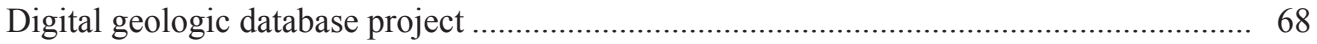

*Geologic Materials Center online sample catalog ............................................................ 69

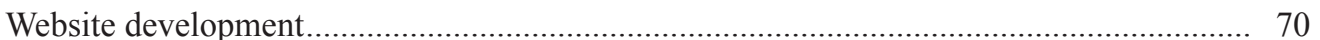

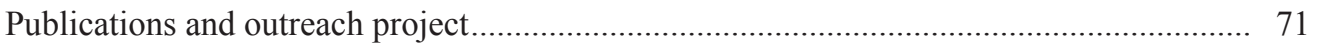

National Geological and Geophysical Data Preservation Program (NGGDPP) ................. 72

GIS-IT infrastructure project ..................................................................................... 73

\section{Geologic Materials Center}

Geologic Materials Center. 


\section{BROOKS RANGE FOOTHILLS AND NORTH SLOPE PROGRAM}

Alaska's North Slope remains one of the most promising onshore oil and gas provinces in all of North America. The Division of Geological \& Geophysical Surveys (DGGS) continues its leadership role in furthering the geologic understanding of this petroleum system, primarily through investigations of rocks exposed in the foothills of the northern Brooks Range. This program was developed in response to the need for high quality, publicly available geologic data to stimulate exploration for hydrocarbons in northern Alaska. The cost of this program is shared by major and independent oil and gas companies. While directed by DGGS, this research effort is a multi-agency collaboration that includes the Alaska Division of Oil \& Gas (DOG), the United States Geological Survey (USGS), the University of Alaska Fairbanks, and others.

During the 2009 field season, the program continued to focus on detailed geologic mapping in the east-central North Slope, extending our observations from the adjacent 2008 STATEMAP area (see p. 34). We also expanded our stratigraphic studies of key reservoir and source-rock intervals, providing new constraints on the depositional history and correlation of geologic units, and leading to an improved understanding of how this hydrocarbon-rich basin evolved. In particular, recent field and analytical work has provided new insight into the sequence stratigraphy of Cretaceous strata, including: (1) constraining the extremely rapid northward fining and thinning of Albian-Cenomanian sandrich facies, (2) documentation of the character and distribution of condensed mudstone sections that are considered excellent regional source rocks (see photo), and (3) recognition of candidate deep-water sequence boundaries and associated potential reservoir targets. In collaboration with DOG, we are integrating these detailed outcrop observations with available well and 2-D seismic data, greatly improving regional geologic models.
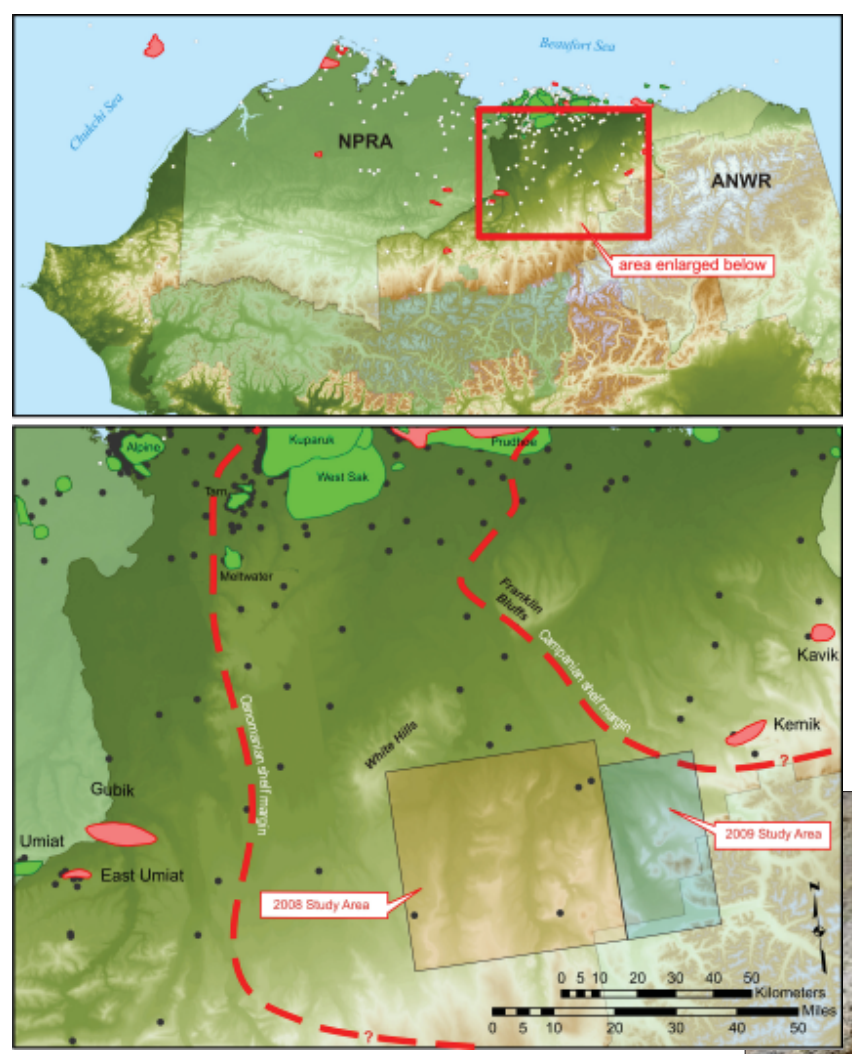

Notable activities related to this program include Energy Resources section chief David LePain's participation in co-organizing a Brookian core workshop held at the 2009 annual meeting of the American Association of Petroleum Geologists (in collaboration with DOG and USGS). Additional results from ongoing studies were also presented in 2009 at the Alaska Geological Society Technical Conference, the Annual Meeting of the Geological Society of America, and a Penrose conference on circum-Arctic geology. Recent DGGS publications from this program include two 1:63,360-scale geologic maps of the inner Brooks Range foothills (Kanayut River and Cobblestone Creek), as well as a series of reports on Cretaceous stratigraphy. Another collection of papers is in progress and will summarize additional structural and stratigraphic studies relevant to evolution of the North Slope petroleum system (anticipated release spring 2010).

Organic-rich shale, silicified tuff, and bentonite of the upper Hue Shale

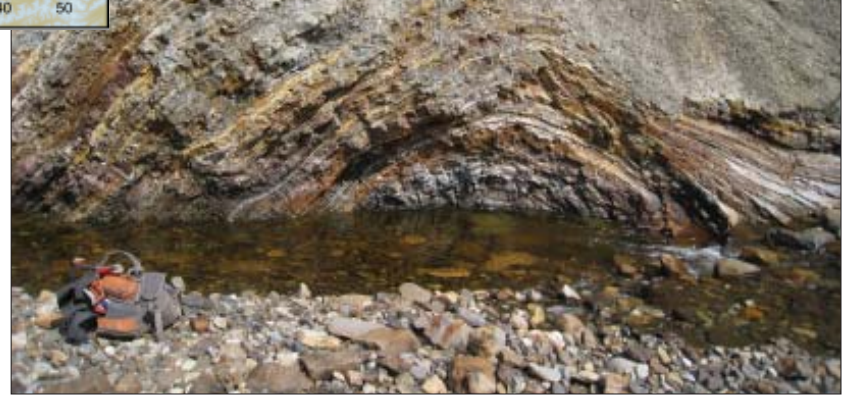




\section{SAGAVANIRKTOK RIVER AREA STATEMAP PROJECT}

Many regions of the North Slope that are prospective for oil and gas exploration are covered by tundra, thus limiting the collection of geologic data to very costly subsurface methods such as seismic reflection and drilling. However, geologic investigation of related rocks exposed at the surface in the northern foothills of the Brooks Range provide a unique opportunity to study structural and stratigraphic relationships, often providing predictive insights into the subsurface

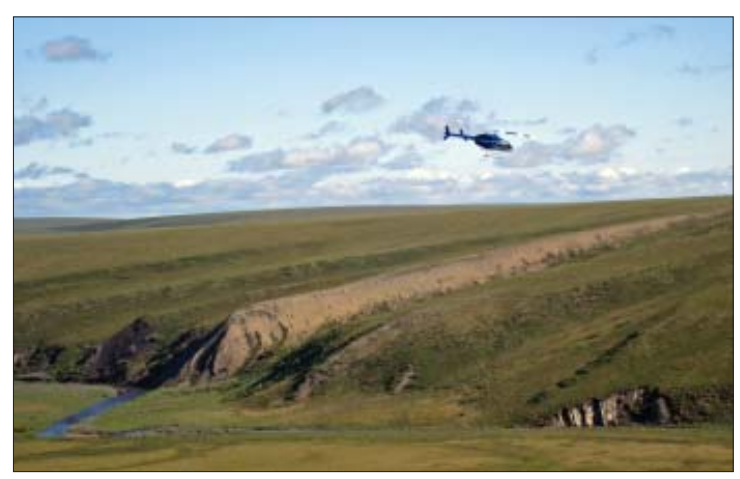
petroleum geology elsewhere on the North Slope. The Energy Resources Section at DGGS conducts bedrock geologic mapping as an integral component of the Brooks Range Foothills and North Slope Program (see also p. 33). Our long-range objective is to produce a contiguous series of detailed geologic maps along the entire foothills belt, thereby establishing a regional geologic framework necessary to understand the evolution of the petroleum system in support of resource management and industry exploration on State lands. In addition, our ongoing work provides critical baseline geologic information that helps constrain the resource potential and long-term supply to the proposed natural gas pipeline.

During the summer of 2008, DGGS, in collaboration with the Alaska Division of Oil and Gas, mapped approximately 600 square miles of the south-central Sagavanirktok Quadrangle at 1:63,360 scale (see map). A significant portion of this area is mantled by younger Quaternary deposits (see p. 58), however the bedrock geology can be pieced together from a series of linear resistant ribs (see photo) that trace out several large folds. The new mapping has improved our understanding of fold geometry, including the recognition of progressive changes in the trend of fold axes, perhaps related to the age of contractional deformation. Additionally, we were able to document significant variability in the plunge of some large anticlinal structures-a key component in evaluating hydrocarbon trapping mechanisms.

Detailed stratigraphic observations also enhanced our knowledge of how Campanian-age (upper Cretaceous) rocks correlate with one another, allowing for a more robust sequence stratigraphic interpretation that integrates the geology of the central and eastern North Slope. To supplement the geologic mapping, we collected an

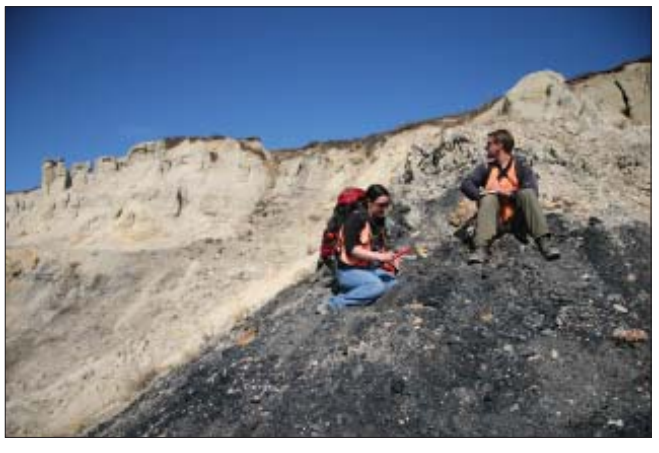
extensive suite of samples to better resolve the age of these potential reservoir rocks. In particular we sampled a large number of thin air-fall volcanic deposits (tuff and bentonite) to date using high-resolution U-Pb zircon geochronology (see photo). During the course of mapping we also documented three oil-stained localities as well as numerous more mildly petroliferous sandstones.

This work was supported in part by the federally funded STATEMAP program administered by the U.S. Geological Survey (USGS). A preliminary digitized map product was submitted to the USGS in the spring of 2009, and a draft version of the map was presented at the 2009 Alaska Geological Society meeting in May. The final map product will be released as a DGGS Report of Investigation late in 2010.

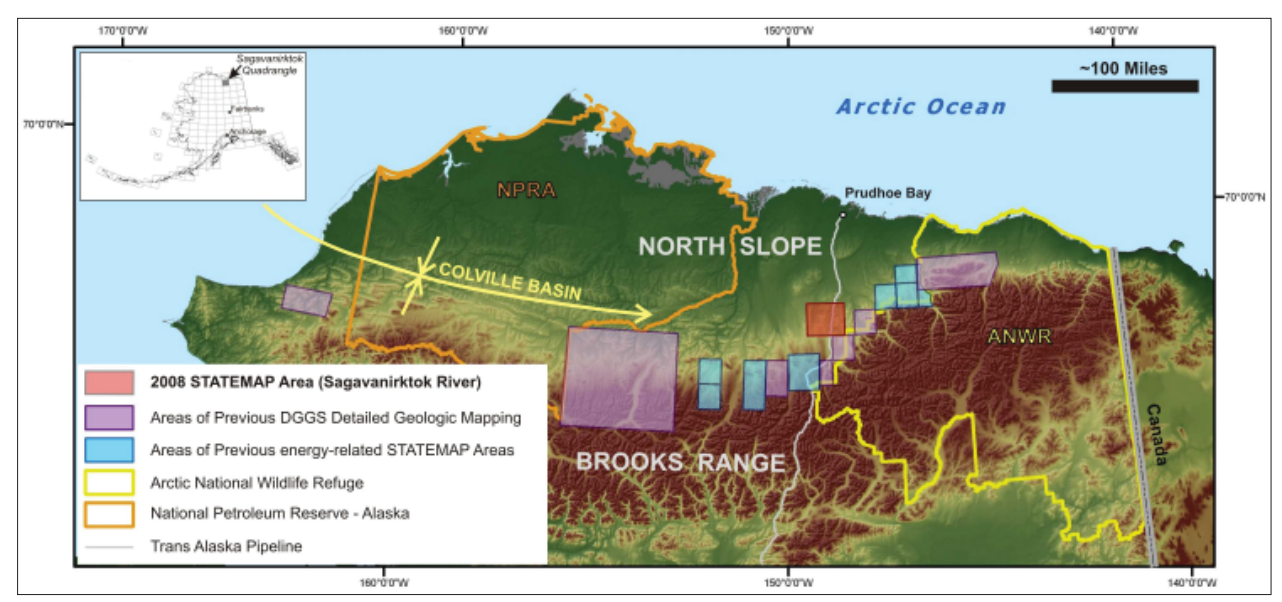




\section{COOK INLET GEOLOGY AND HYDROCARBON POTENTIAL PROGRAM}

Increasing demand and predicted deliverability shortfalls for Cook Inlet natural gas to south-central Alaska customers pose a looming threat to the region's economy and energy supply. These factors make it an ideal time to encourage new exploration investment in the Cook Inlet region. The Alaska Division of Geological \& Geophysical Surveys (DGGS) is responding to this challenge by leading a multi-year, multi-agency program of relevant applied geologic research designed to provide high-quality data to the geologic community and public policy makers. This program is a collaborative effort between DGGS, the Alaska Division of Oil and Gas (DOG), the University of Alaska Fairbanks, and the U.S. Geological Survey.

Historically, Cook Inlet exploration has focused on the search for large, faulted fold structures with four-way closure. Now that nearly all large structures have been found and tested, the exploration focus is gradually shifting to subtle stratigraphic traps and reservoirs in low porosity and permeability formations. Successful exploration for these features requires detailed knowledge of potential reservoir geometries, geologic factors controlling these geometries, and geologic controls on reservoir producibility. The goal of this program is to improve understanding of potential reservoir geometries and their geologic controls.

During 2009 DGGS and DOG continued documenting the geom-

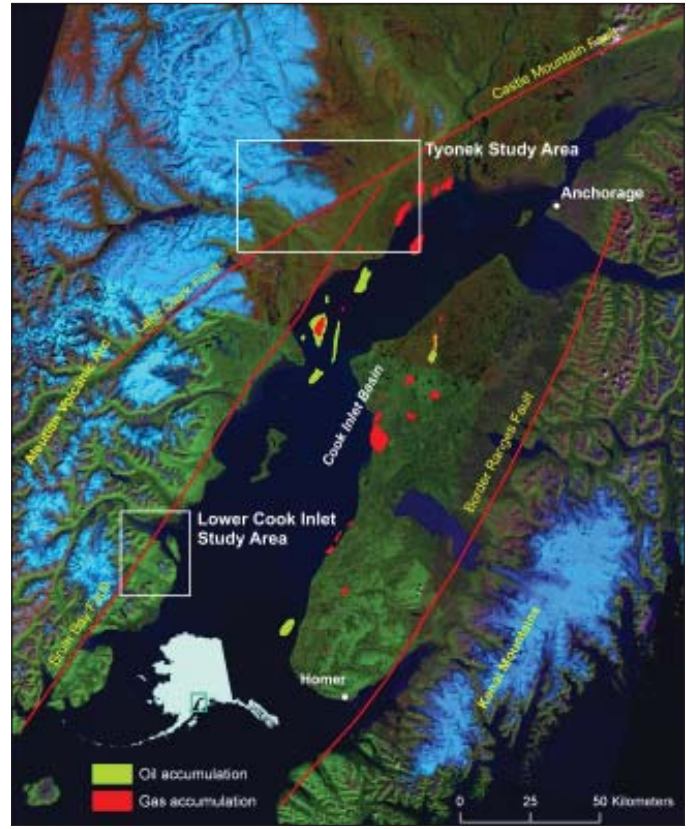

Figure 1. Satellite image showing major faults and oil and gas fields in Cook Inlet basin. etry of potential reservoir sand bodies in Tertiary-age nonmarine sandstones in the Capps Glacier-Beluga River region west of Anchorage, and began work on Mesozoic-age rocks exposed along the west side of lower Cook Inlet, due west of Anchor Point (fig. 1). Work in the former area has helped to document alluvial fan and associated gravelly river deposits along the western basin margin. These rocks record

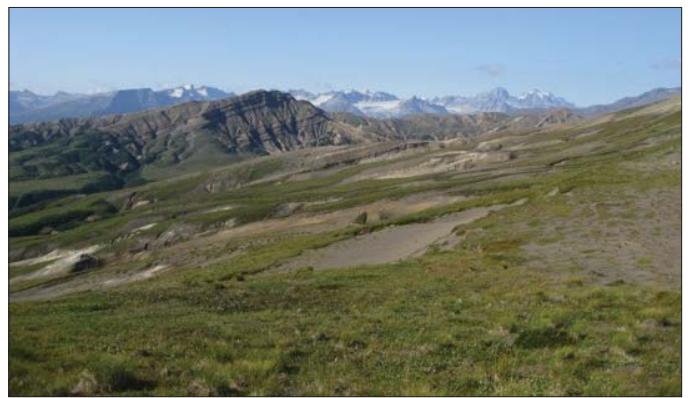

Figure 2. Sedimentary rocks near Capps Glacier with thick volcanic ash layers (white material near left margin of photograph).

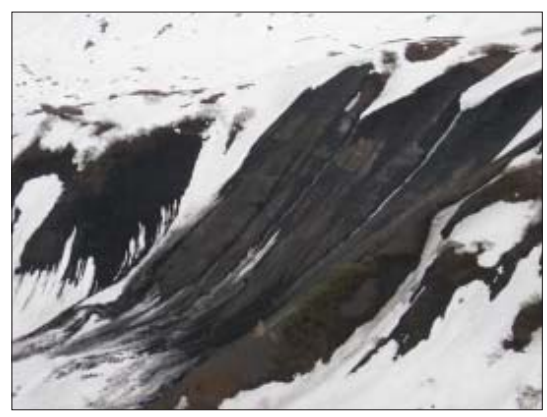

Figure 3. Outcrops of dark gray to black organic-rich mudrocks near Red Glacier in Lake Clark Park and Preserve. deposition during a period characterized by basin-margin faulting and significant volcanic activity (fig. 2). The latter had a dramatic effect on the composition of sediment and resulting reservoir quality. As part of this project, DGGS began detailed geologic mapping in this area in 2009 (see project description on p. 36). An important component of this program is a study that is underway to document the subsidence history of upper Cook Inlet. This work is a significant step in the process of developing models that will facilitate pre-drill predictions of reservoir quality.

Collectively, all of this work is improving our understanding of sand-body geometries and reservoir quality of rocks that serve as producing reservoirs in nearby fields such as Granite Point. Work in lower Cook Inlet is documenting the reservoir potential of Mesozoic-age sandstones and the petroleum source-rock characteristics of Middle Jurassic mudstones (fig. 3). These mudstones served as the source for most, if not all, oil in upper Cook Inlet fields. Another important component is an effort to map the base of the Tertiary succession throughout upper Cook Inlet and to map the subcrop pattern of underlying Mesozoic strata, including the same Middle Jurassic-age mudstones seen in outcrop, to understand their distribution relative to porous reservoir rocks in the overlying stratigraphy.

This project is funded by the State of Alaska and an industry consortium consisting of Benchmark Oil and Gas, Chevron North America, and Pioneer Natural Resources. Results of this work have been documented in a series of publications available from the DGGS website (http://www.dggs.dnr.state. ak.us/). Additional publications will be released as they become available during FY2010. 


\section{GEOLOGIC MAPPING IN THE TYONEK-CAPPS GLACIER AREA}

Gas production from Cook Inlet basin has contributed significantly to Alaska's economy by providing inexpensive natural gas for industrial use, electric power generation, home heating fuel, and job creation for south-central Alaska. Rising demand, predicted deliverability shortfalls, and volatility in commodity prices underscore the need for additional gas reserves in Cook Inlet. Despite the growing need and significant remaining gas potential, exploration interest in the basin remains weak. DGGS is pursuing a program in the Cook Inlet region focused on understanding the potential for stratigraphic traps and gas reservoirs in low porosity and permeability (tight) formations (see briefing paper on p. 35). This program includes detailed geologic mapping of areas where outcrop relations are complex, poorly understood, and important for understanding the potential for gas reservoirs in stratigraphic traps and tight formations.

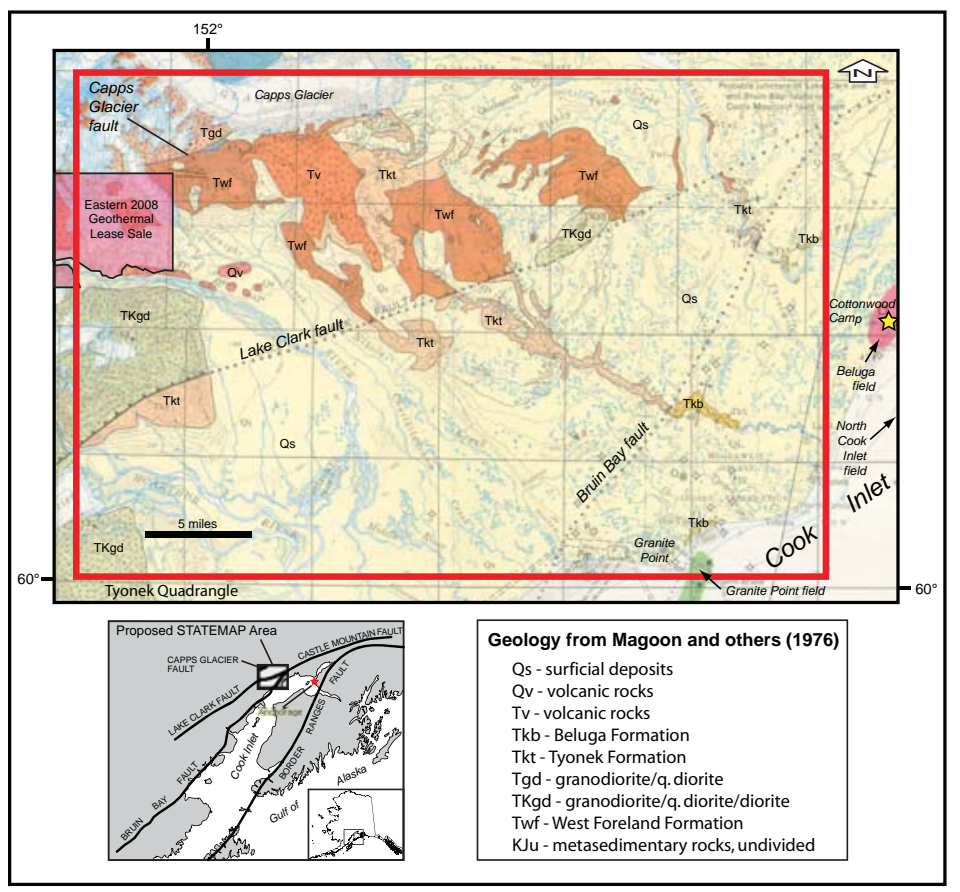

During the summer of 2009, DGGS completed 1:63,360-scale geologic mapping of nearly 400 square miles in the Tyonek Quadrangle, north of the Lake Clark fault (see inset map). This area straddles the northwestern margin of Cook Inlet basin and includes some of the best exposures of Tertiary formations in the region (see inset picture), some of which serve as reservoirs in the nearby Beluga, North Cook Inlet, and Granite Point fields. Available geologic mapping in the area either predates modern stratigraphic nomenclature used in the basin or lacks structural details necessary for reconstructing the geologic history important for understanding controls on reservoir geometries and quality, both of which are critical to assessing the potential for stratigraphic traps and reservoirs in tight formations. Our mapping has unraveled complex stratigraphic and structural relations and represents a major step forward in understanding the geologic evolution of the northwestern margin of the basin, including formation of the above oil and gas fields. Concurrent with bedrock mapping, detailed mapping of the surficial geology has led to improved understanding of the glacial history of the region and its sand and gravel resources. Analysis of seismic hazards that represent potential threats to nearby population centers and petroleum production infrastructure is also underway as part of this project. Mapping will resume during the summer of 2010 and focus on the area south of the Lake Clark fault. Our work in this area will help spur exploration interest and investment in Cook Inlet basin.

Preliminary 2009 mapping was completed with partial funding from the U.S. Geological Survey's STATEMAP program and will be submitted to that organization in late spring 2010. Results from related stratigraphic and structural studies will be published as DGGS reports by mid 2010. Pending receipt of STATEMAP funding, preliminary mapping of the southern half of the project area will commence in summer 2010. A preliminary map of the entire project area will be submitted to the U.S. Geological Survey in spring 2011.

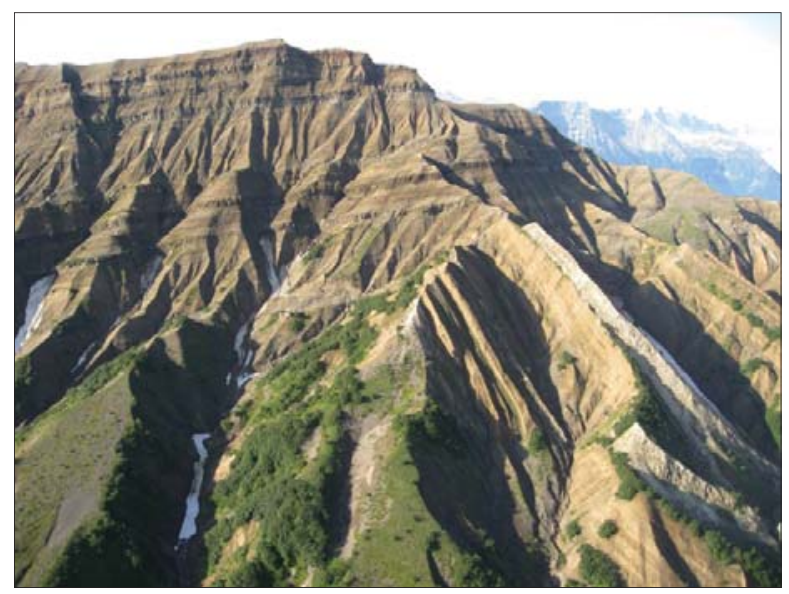




\section{REFINING ESTIMATES FOR ALASKA COAL SEAM CARBON SEQUESTRATION}

Carbon dioxide $\left(\mathrm{CO}_{2}\right)$ capture and storage technologies could play a critical role in mitigating the impact of fossil-fuel-based electricity generation on greenhouse gas buildup. Nearly one-third of the carbon emissions in the U.S. come from power plants. Geologic sequestration of $\mathrm{CO}_{2}$ generated from fossil fuel combustion may be a viable method to reduce the amount of greenhouse gas emissions. In the subsurface, coal seams often contain gases such as methane. The gas is held in pores on the surface of the coal and in fractures in the seams. If $\mathrm{CO}_{2}$ is injected into a coal seam it displaces the methane, and can remain stored within the seam, providing the coal is never disturbed. Tests have shown that the adsorption rate for $\mathrm{CO}_{2}$ is approximately twice that of methane. Sequestering $\mathrm{CO}_{2}$ in coal beds has

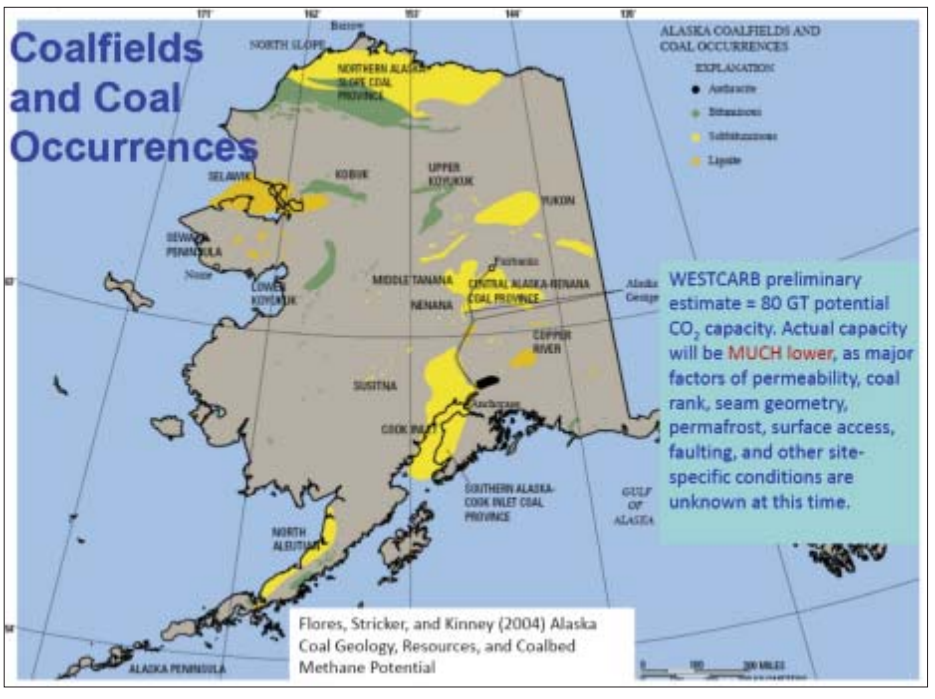
several advantages. For example, $\mathrm{CO}_{2}$ injection can enhance methane production from coal beds. Since 1995, Burlington Resources has been injecting carbon dioxide into wells in the San Juan Basin in New Mexico to recover more methane from the coal beds. And since 1997, BP America has been similarly injecting nitrogen in their wells in the San Juan. Although Burlington's goal in injecting the carbon dioxide has been to increase methane production, it has already sequestered more than 300,000 tons of carbon dioxide. However, their carbon dioxide is from natural underground reservoirs and not anthropogenic sources.

The West Coast Regional Carbon Sequestration Partnership (WESTCARB) is identifying and validating carbon sequestration opportunities in California, the surrounding states of Arizona, Nevada, Oregon, Washington, Alaska, and the Canadian Province of British Columbia. Findings from the first phase of WESTCARB's regional characterization of geologic formations and managed land suitable for long-term $\mathrm{CO}_{2}$ storage (known as 'sinks') indicated a lack of data in many key areas.

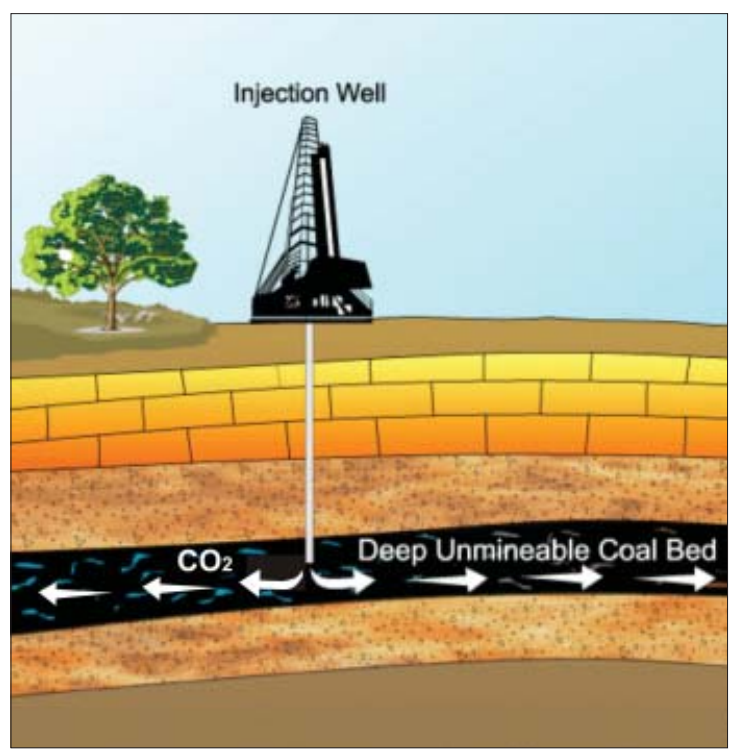
The Alaska Division of Geological \& Geophysical Surveys is refining the coal estimates for storage of $\mathrm{CO}_{2}$ in deep, unmineable coal seams. This project is the second task under a larger project, Alaska Geologic Carbon Sequestration Potential Estimate: Screening Saline Basins and Refining Coal Estimates, being conducted by the Division of Oil \& Gas. The general objective of the Alaska coal-seam storage refinement task is to evaluate the preliminary estimated volume for Alaska coal-seam $\mathrm{CO}_{2}$ storage (1,605 Tcf; $84 \mathrm{GT}$ ). It is likely that only a portion of the $84 \mathrm{GT}$ would be considered favorable for $\mathrm{CO}_{2}$ sequestration, due to low permeability, seam geometry, surface access, faulting, permafrost, and other site-specific conditions. New data and the addition of constraints will be used to augment and refine these estimates.

DGGS's task is to refine current coal-capacity maps through revised estimates of non-mineable coal, expected coal rank, cleating, and coal-permafrost relationships. Volumetric estimates of coal distribution and depth will be constrained using new available data and existing mapping. DGGS will:

- Produce a derivative map of coal available for sequestration using filters of coal rank, depth, lateral distribution, permafrost, and infrastructure.

- Estimates will be made in accordance with established methodology unless otherwise documented.

A technical report on refinements to coal seam storage of $\mathrm{CO}_{2}$ for Alaska will be submitted to WESTCARB at the end of March 2010. 


\section{ALASKA COAL DATABASE - NATIONAL COAL RESOURCE DATABASE SYSTEM}

The long-term goal of the Alaska Division of Geological \& Geophysical Surveys' (DGGS) participation in the U.S. Geological Survey's (USGS) National Coal Resource Database System (NCRDS) cooperative program is to record all known coal occurrences in Alaska and archive the information in a single, readily accessible database available at the USGS Web site, http://energy.er.usgs.gov/products/databases/USCoal/. The NCRDS program is funded by USGS through a multi-year proposal process with final reporting at the end of each funding period.

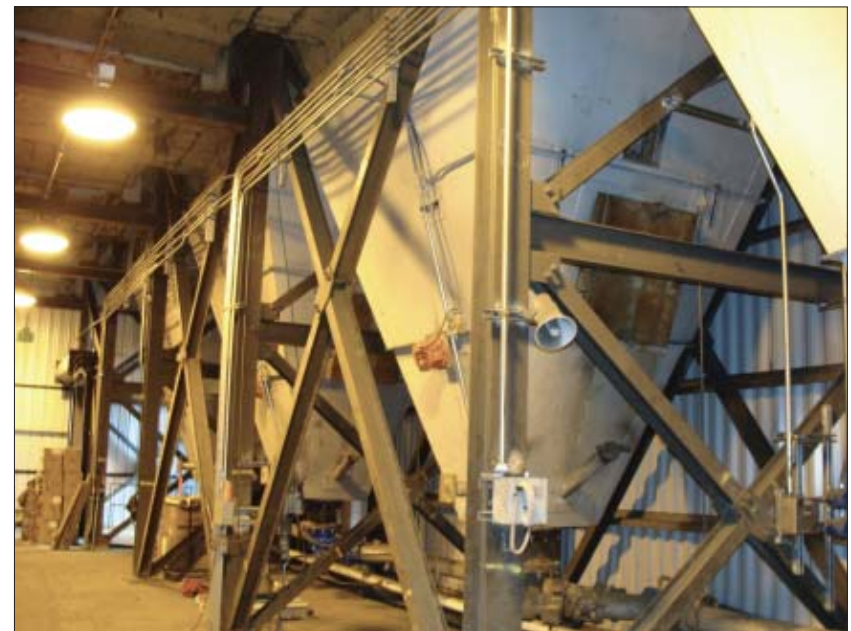

Ash hoppers in the Chena 5 power plant
The USGS has recently focused its efforts on studies that examine the feed coals and coal combustion products from individual coal-fired power plants that can potentially have adverse effects on environmental quality and/or may be slated for regulation. These studies take a cradle-to-grave approach and focus on the occurrence and formation of different elements and compounds throughout the spectrum of mining, production, transportation, and most importantly, combustion of coal. This study is examining the chemical nature (major-, minor-, and trace-element and mineralogical composition) of the feed coal, fly ash, and bottom ash at the Aurora Energy's Chena No. 5 power plant in Fairbanks. These data will help to better understand the potential environmental impact of coal combustion processes and products.

During July 2008, the Aurora Energy Chena No. 5 power plant was sampled for a 19-day period. Samples collected by Aurora Energy personnel followed the flow of coal in the power plant and were taken at five fly ash disposal sites (1-5 in simplified diagram of the power plant); the Usibelli Coal Mine feed coal was also sampled. The ash sampling sites consisted of the Bottom Ash directly below the boiler (4), the First Ash Hopper (3), Last Ash Hopper (2), the Fly Ash Hopper beneath the gas stack (1), and the Silo Ash Mix in the storage silo (5).

Samples were sent to the USGS coal laboratory in Denver, Colorado, for proximate and ultimate analyses of the feed coal and trace element analyses of the ash and feed coal. During fall 2009, the USGS laboratory completed their analyses of the samples and they are currently collating their data and verifying quality control of the analytical data results.

The determination of elements in feed coal is important because the content, distribution, and be-

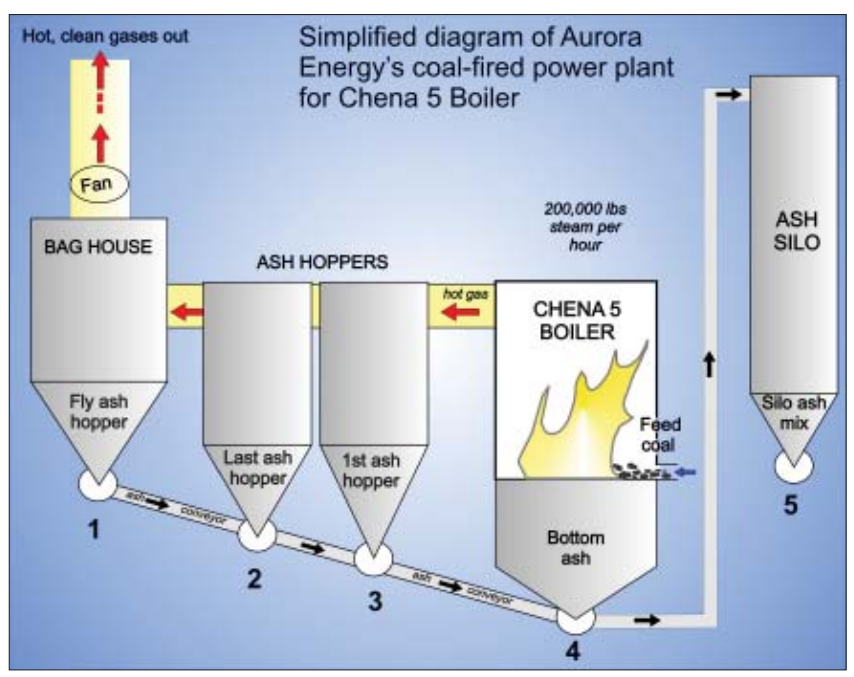
havior of elements during and after combustion depend in large part on the content and distribution of trace elements in the feed coal. Alaska coal generally is very low in sulfur and other hazardous air pollutants. This study of actual pre- and post-combustion data on Healy coal will allow us to develop better predictive models of the fate of coal combustion-derived elements in the biosphere. DGGS will assist in co-authoring several reports resulting from this project that document the collection and processing of these Alaska samples, and will input relevant sample collection data into the USGS geochemical laboratory database and the NCRDS database. Drafts of these reports will be completed by June 2010. DGGS will also play a role in helping the USGS present this data to other groups through various short courses and tutorials. 


\section{AIRBORNE GEOPHYSICAL/GEOLOGICAL MINERAL INVENTORY PROGRAM: AIRBORNE GEOPHYSICAL SURVEY OF THE MORAN AREA, MELOZITNA MINING DISTRICT, CENTRAL ALASKA}

The Airborne Geophysical/Geological Mineral Inventory (AGGMI) program is an annual investment to expand the knowledge base of Alaska's mineral resources and catalyze private-sector mineral development. The project seeks to delineate mineral zones on Alaska state lands that: (1) have major economic value; (2) can be developed in the short term to provide high-quality jobs for Alaska; and (3) will provide economic diversification to help offset the loss of Prudhoe Bay oil revenue. Candidate lands for this project are identified on the basis of existing geologic knowledge, land ownership, and responses to solicitations for nominations from Alaska's geologic community. Products resulting from these surveys generally include (1) 1:63,360-scale aeromagnetic and airborneelectromagnetic maps; (2) 1:63,360-scale geologic maps; and (3) various other geological, geochemical, and geophysical data compilations. As a result of this program, millions of dollars of venture capital have been spent in the local economies of the surveyed mining districts and adjacent areas in direct response to the new geologic knowledge provided by the surveys.

Through the AGGMI program, DGGS is acquiring airborne-geophysical data in FY10 for an area in the Tanana and Melozitna quadrangles roughly centered on Moran Creek and Moran Dome. The 650-square-mile survey tract, about 150 miles west-northwest of Fairbanks and 25 miles west of the village of Tanana, contains a mixture of State and Native lands in the Melozitna mining district. The area has not been extensively explored, but the district contains known plutonic-related lode-gold prospects, and has the potential for hosting porphyry copper \pm molybdenum \pm gold, mesothermal, epithermal, proximal to distal skarn, and polymetallic vein deposits. Structurally controlled, stacked, gold-bearing quartz veins occur at the Gold Hill lode gold prospect. Ductile to brittle structural features (including high- and low-angle faults), as well as metamorphic-stratigraphic controls, may play a significant role in controlling the localization of mineralization. About 13,000 troy ounces of placer gold have been produced from the Melozitna mining district. Reconnaissance geologic mapping suggests the area is composed largely of Paleozoic pelitic schist and quartzite, with lesser greenstone, greenschist, and calcareous rocks. Plutons of various compositions intrude the area. The Kaltag fault, a regional-scale, strike-slip fault, underlies and is sub-parallel to the Yukon River in this area, but may have a large splay north of the Yukon River in the eastern survey tract.

Airborne-geophysical surveys enable users to delineate regional structures, and identify metamorphic-stratigraphic lithologies and plutonic rock types based on their geophysical characteristics. Follow-up geologic mapping tests geophysical anomalies and interpretations, and provides detailed documentation of the types, locations, and spatial distribution of metamorphic and plutonic rocks and structural features. By completing an integrated geophysical-geological mineral inventory study, new zones of mineralization may be identified, and extrapolation of some of the information into surrounding areas may be appropriate.

Geophysical information being acquired for the Moran area includes aeromagnetic, electromagnetic, and radiometric data. Maps and digital data will be released as DGGS Geophysical Reports in early winter 2010. A second publication, containing a project report, interpretation, and electromagnetic anomalies, will be released in summer 2010. DGGS believes these data will lead to a better understanding of the geologic framework of the area and will stimulate increased mineral exploration investment within the survey boundary and the surrounding area.

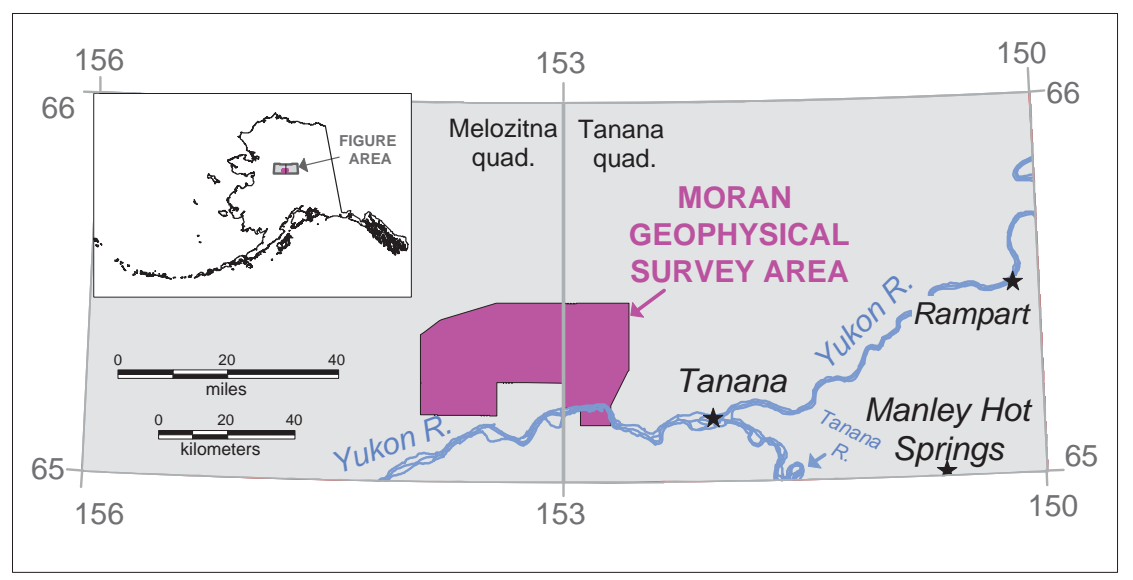




\section{AIRBORNE GEOPHYSICAL/GEOLOGICAL MINERAL INVENTORY PROGRAM: BEDROCK GEOLOGIC MAPPING OF THE SLATE CREEK AREA, MT. HAYES QUADRANGLE, SOUTH-CENTRAL ALASKA}

The Alaska Division of Geological \& Geophysical Surveys (DGGS) released airborne magnetic and electromagnetic geophysical maps for 442 square miles of the northern Chistochina mining district in early 2009. DGGS conducted geologic mapping of about 113 square miles of the geophysical survey tract during July 2009. This mapping project is funded primarily by State CIP funds, with supplementary Federal STATEMAP funding. The Slate Creek mapping project is part of DGGS's Airborne Geophysical/Geological Mineral Inventory program, a special multi-year investment by the State of Alaska to expand Alaska's geologic and mineral resources knowledge base, catalyze future private-sector mineral exploration and development, and guide state planning.

The Slate Creek study area is in the southern foothills of the Alaska Range about 140 miles southeast of Fairbanks and 20 miles east of Paxson's location on the Richardson Highway. Approximately 183,000 ounces of placer gold have been mined from the region since 1898, with most production from the historic Slate Creek subdistrict. One active placer gold mine, 64 inactive placer gold occurrences and mines (with minor platinum-group metals [PGM]), and 29 metallic lode occurrences are present in the map area. There are no significant known lode gold occurrences to explain the extensive placers. Previous workers have proposed various gold-source models including reworked auriferous Tertiary gravels, hydrothermally altered turbidite deposits, and gold-bearing volcanogenic massive sulfide deposits. The Slate Creek area also hosts many plutonic-related skarn, replacement, and vein-gossan occurrences, potential porphyry(?) copper-gold lode prospects, and copper-nickel-PGM lode occurrences associated with mafic-ultramafic rocks of two possible ages.

A portion of the main strand of the Denali Fault System (DFS), which ruptured in 2002 (with an associated magnitude 7.9 earthquake), is included in and bounds the northern edge of the study area. DGGS is identifying, determining orientations, and characterizing the kinematics of active and inactive faults along the DFS and subsidiary faults to provide a better understanding of the regional stress regime. These data are necessary for subsequent assessment of earthquake hazards to critical infrastructure and population centers. Conflicting reports on the nature of the prominent Slate Creek fault system, which is subparallel and likely related to the DFS, also highlight the need for DGGS's detailed mapping and neotectonic studies in this area. The neotectonic study of recent fault movement along the Denali fault trace and subsidiary faults is described separately (p. 54).

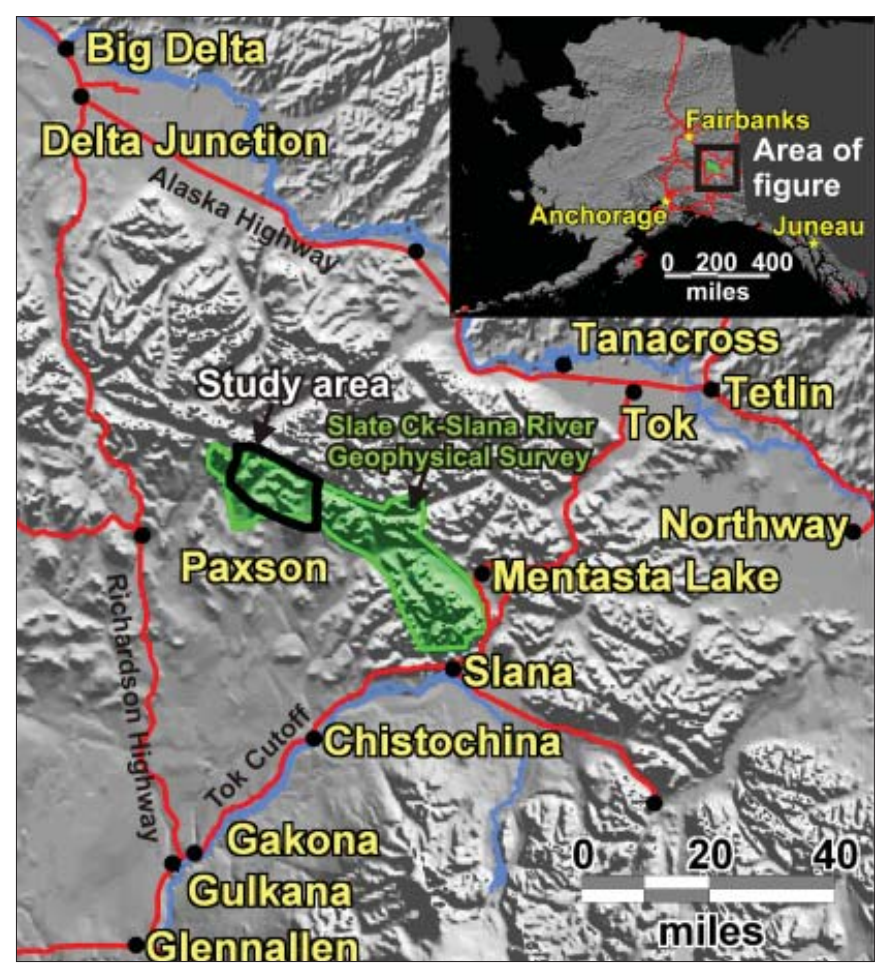

New geologic mapping and neotectonic studies, incorporating interpretations of DGGS's airborne geophysical data, will lead to a better understanding of the region's geologic framework, provide data on recent fault movement essential to geologic hazard assessments, provide geologic-resource data critical to land-use decisions, and help to stimulate increased mineral exploration investment within this belt of rocks. Products will be a series of geologic maps at 1:50,000 scale, and reports containing geological, geochemical, and geophysical data. Geologic maps of the Slate Creek area will be completed by late 2010. Surficial-geologic mapping performed in conjunction with this project is described separately (p. 57).

Locations of the Slate Creek map area (black outline) and airborne-geophysical survey area (green polygon) in relation to rural communities and transportation corridors. Base map is a digital elevation model with a grid-cell size of $300 \mathrm{~m}$. 


\section{AIRBORNE GEOPHYSICAL/GEOLOGICAL MINERAL INVENTORY PROGRAM: GEOLOGIC MAPPING IN THE EASTERN BONNIFIELD MINING DISTRICT, HEALY AND FAIRBANKS QUADRANGLES, ALASKA}

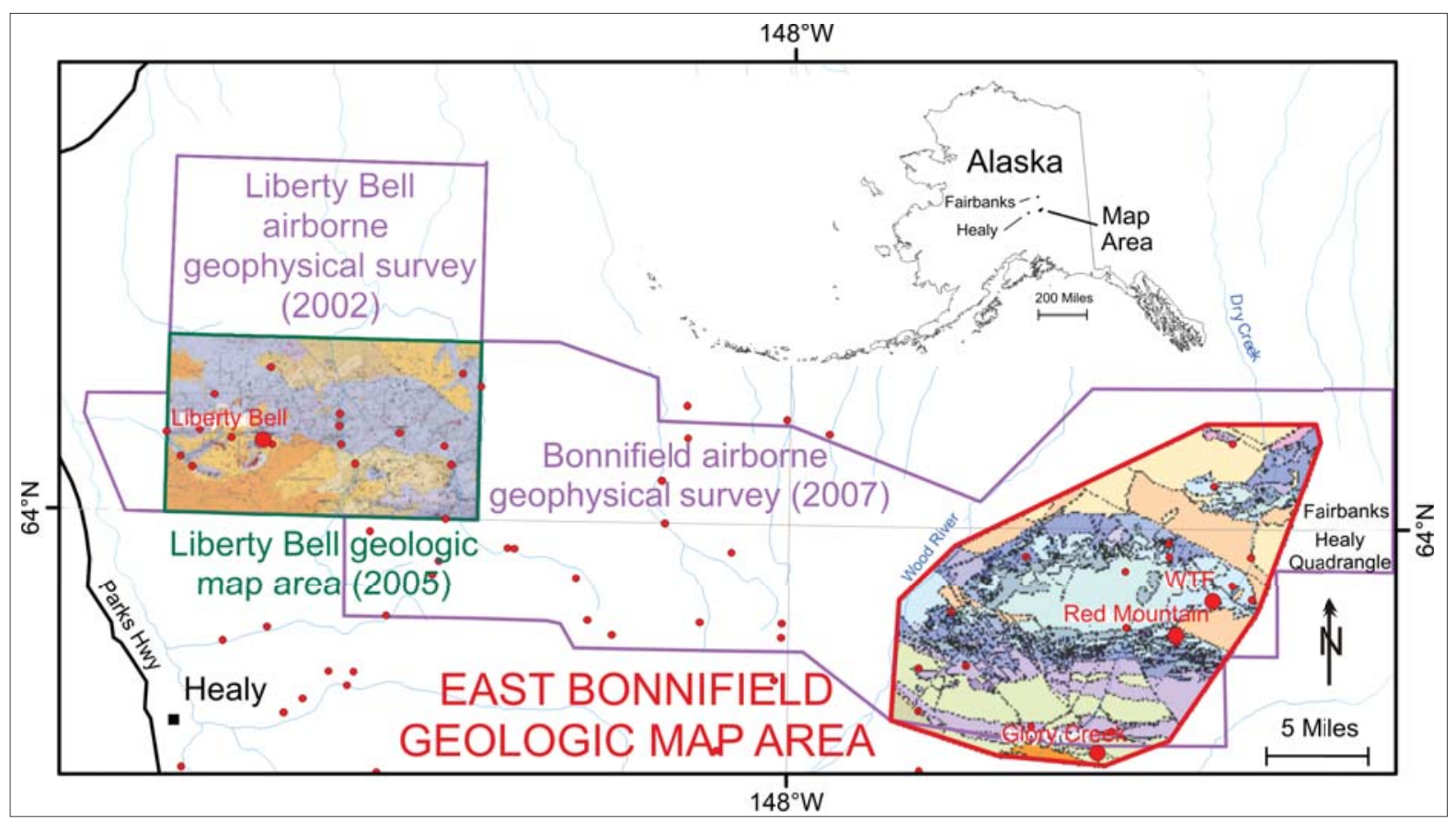

Historic and active placer mines in the Bonnifield mining district have produced more than 86,000 ounces of gold; the region also contains numerous significant polymetallic volcanogenic massive sulfide (VMS) and gold-polymetallic pluton-related lode occurrences. To encourage renewed industry exploration for mineral deposits in this region, and to provide geologic data for State and local land-use management, in 2007 the Alaska Division of Geological \& Geophysical Surveys (DGGS) released a 613-square-mile airborne-geophysical survey for the eastern two-thirds of the area outlined in magenta (see figure) as part of the State-funded Airborne Geophysical/Geological Mineral Inventory program. In summer 2008, DGGS conducted fieldwork to geologically map an approximately 200-square-mile area in the eastern Bonnifield mining district (area outlined in red; see figure). A geochemical data report was published in 2009, and 1:50,000-scale bedrock- and comprehensive-geologic maps will be published in 2010. This project is funded primarily by State Capital Improvement Project (CIP) funds, with supplemental funding through the Federal STATEMAP program.

The eastern Bonnifield map area is 60 miles south of Fairbanks in the northern foothills of the Alaska Range. The map area contains significant mineral occurrences, most notably the WTF and Dry Creek VMS prospects, which contain drill-inferred resources of $\mathrm{Cu}, \mathrm{Pb}, \mathrm{Zn}, \mathrm{Ag}$, and Au. Lithologic and structural relationships and interpretations depicted on 50-year-old published geologic maps are not supported by our summer 2008 investigations. DGGS's new geologic map incorporates interpretations of our Bonnifield airborne geophysical survey data, aerial photographs, donated industry data, and our 2008 field observations and new scientific analytical data. Our work documents many sets of newly discovered inactive faults and one potentially active fault, and presents a revised stratigraphic section based on actual lithologic units instead of grouped rock packages.

The primary objective of the eastern Bonnifield project is to map the geology in sufficient detail to facilitate wise State and local land-use decisions and to guide mineral industry exploration efforts. The timing of this project coincides with renewed mineral-industry interest in exploration for volcanogenic massive sulfide deposits including those in the eastern Bonnifield mining district; exploration activity in Alaska in general is at an all-time high. Because economic development could potentially come into conflict with other land uses, the availability of our detailed geologic, resource, and reconnaissance hazard assessments is important for long-range planning. Providing a basic geologic framework and an inventory of potentially mineralized areas will help State and local planners balance the need for resource development versus other land-management strategies. Geologic maps and data produced by this project will also serve as a framework for further scientific studies and increased regional understanding of this tectonically active area, which is 21 miles north of the Denali Fault. 


\section{ALASKA GEOPHYSICAL/GEOLOGICAL MINERAL INVENTORY PROGRAM: BEDROCK GEOLOGIC MAPPING OF THE NORTHERN FAIRBANKS MINING DISTRICT, CIRCLE QUADRANGLE, ALASKA}

In summer 2007, the Alaska Division of Geological \& Geophysical Surveys (DGGS) conducted 189 square miles of geologic mapping northeast of Fairbanks, covering the central portion of DGGS's 404-square-mile Northeast Fairbanks airborne magnetic and electromagnetic geophysical surveys released in January 2006. The mapping project is funded primarily by DGGS's Airborne Geophysical/Geological Mineral Inventory program, an annual investment by the State of Alaska to expand Alaska's geologicand mineral-resources knowledge base, catalyze future private-sector mineral exploration and development, and guide state planning. Other funding sources include the federal STATEMAP program and the State's General Fund.

The Steese Highway bisects the study area from

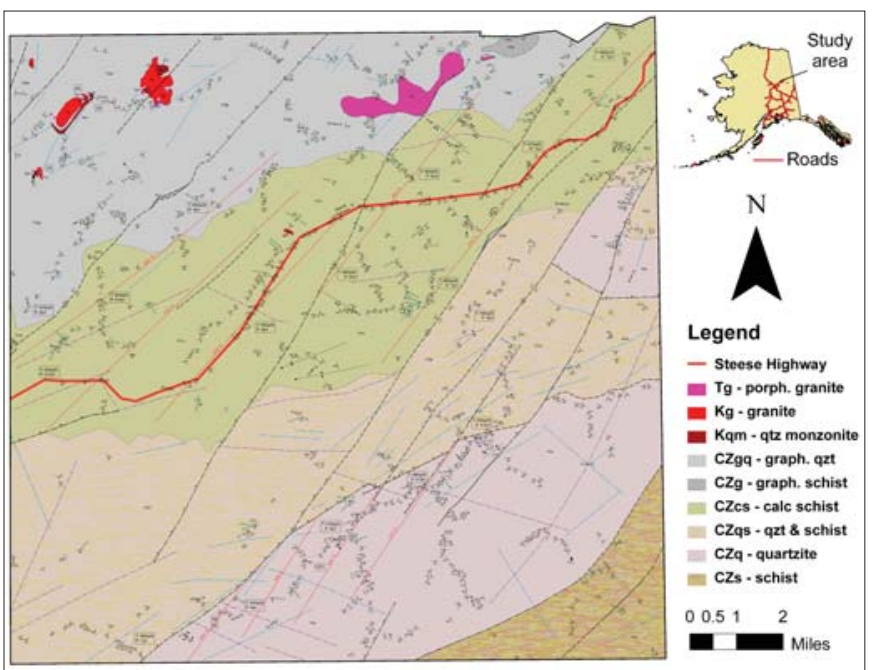

Draft bedrock geologic map. highway mileposts 66 to 85. Good access from the highway, placer mining roads, and a few trails, in addition to nearby power from the high-voltage power lines of the Fort Knox gold mine 25 miles to the southwest, would facilitate possible mineral development. The map area lies in a northeast-oriented trend of plutonic-related gold mineralization between the central and southwestern Fairbanks and Circle mining districts. The Fairbanks mining district has the largest historic gold production in Alaska, with nearly 12.9 million troy ounces of gold produced as of 2007. Three placer mines (two active) and one lode gold prospect are present in the Northeast Fairbanks map area. Placer gold is spatially associated with

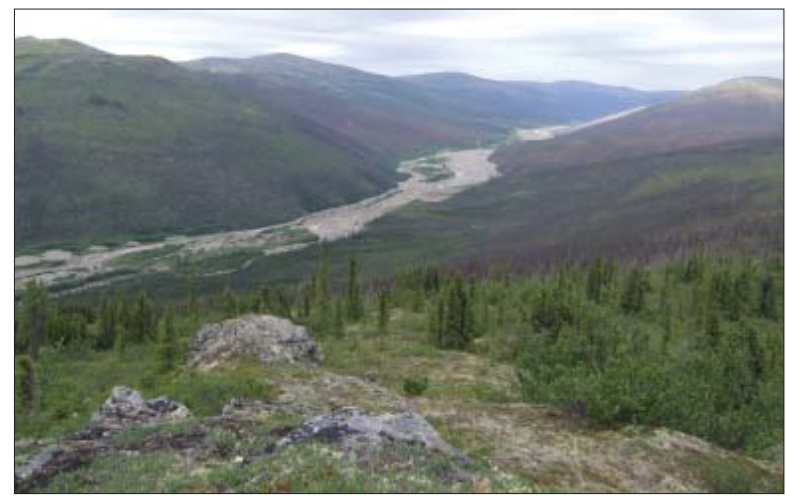

View, looking north, of the Faith Creek gold placer. monzogranite and quartz monzonite plugs, dikes, and sills. The distribution of pay streaks within the placers and paucity of mineralization within the intrusions suggest some of the gold may be structurally controlled. In 2007, DGGS identified arsenopyrite-pyrite-quartz veins and boxworks and semi-massive stibnite-quartz veins proximal to the intrusive suite.

In addition to geologic mapping, DGGS conducted a rock and stream-sediment geochemical study instrumental in the Alaska Division of Mining, Land \& Water's decision to relocate a portion of the proposed Mount Ryan Remote Recreational Cabin Sites Staking Area to an area with lower perceived mineral potential. Because land opened to settlement is usually closed to mineral exploration and development, knowledge of an area's mineral potential is crucial to decisions on whether to retain that land for subsurface users. These geochemical data were published in January 2008.

DGGS's geologic mapping incorporates interpretations of our airborne geophysical data, and will provide: (1) a better understanding of the lithologic, metamorphic, and tectonic framework of Interior Alaska; (2) baseline geologic-materials and hazards data for future infrastructure and settlement construction, and current maintenance of the Steese Highway; (3) geologic-resource data critical to land-use decisions; and (4) geologic knowledge that will help encourage mineral exploration investment in the northern section of the Fairbanks mining district. A series of 1:50,000-scale geologic maps and associated scientific studies for this project will be completed in 2010. 


\section{AIRBORNE GEOPHYSICAL/GEOLOGICAL MINERAL INVENTORY PROGRAM: BEDROCK GEOLOGIC MAPPING IN THE COUNCIL-BIG HURRAH-BLUFF AREA, SEWARD PENINSULA, ALASKA}

More than 1 million ounces of placer gold have been extracted from the Solomon-Council area of Alaska's Seward Peninsula during the past century, but gold production has declined in recent decades. To encourage renewed industry exploration for lode gold and base-metal deposits in this region, and to provide geologic data for land-use management, in 2003 the Alaska Division of Geological \& Geophysical Surveys (DGGS) released airborne-geophysical surveys for the area outlined in purple (see figure). These surveys are part of the Airborne Geophysical/ Geological Mineral Inventory (AGGMI) program, supported by State Capital Improvement Project (CIP) funds. In 2004, DGGS conducted 1:50,000-scale geologic mapping and geochemical sampling in the Big Hurrah and Council areas (green outline in figure).

In 2006, DGGS extended this mapping into the Casadepaga River-Bluff area (red outline in figure), and will produce a combined map and a geologic report of the entire project area in 2010. A geochemical report for the 2006 map area was released in October 2007. This part of the project is primarily supported by the State CIP-funded AGGMI program, and was partially supported in 2007 by the Federal STATEMAP program. The purpose of DGGS's mapping is to provide geologic context for known lode gold and base-metal deposits and occurrences, and evaluate the area's mineral-resource potential. The Casadepaga River-Bluff map area contains the Bluff lode gold prospect, and covers the headwaters of the Casadepaga River, known for its rich placer gold deposits. The lode sources of this placer gold have not yet been identified.

The Casadepaga River-Bluff area is underlain by Proterozoic to Lower Paleozoic metasedimentary and metaigneous rocks of the Nome Group, including the Solomon Schist, Mixed Unit, Casadepaga Schist, and undifferentiated marble. DGGS's recent detailed geologic mapping defines the internal metamorphic stratigraphy of these rock units, and is revealing new relationships between units as well. Efforts to determine their depositional ages are in progress. Stratigraphic relationships and depositional-age data are essential for evaluating the economic

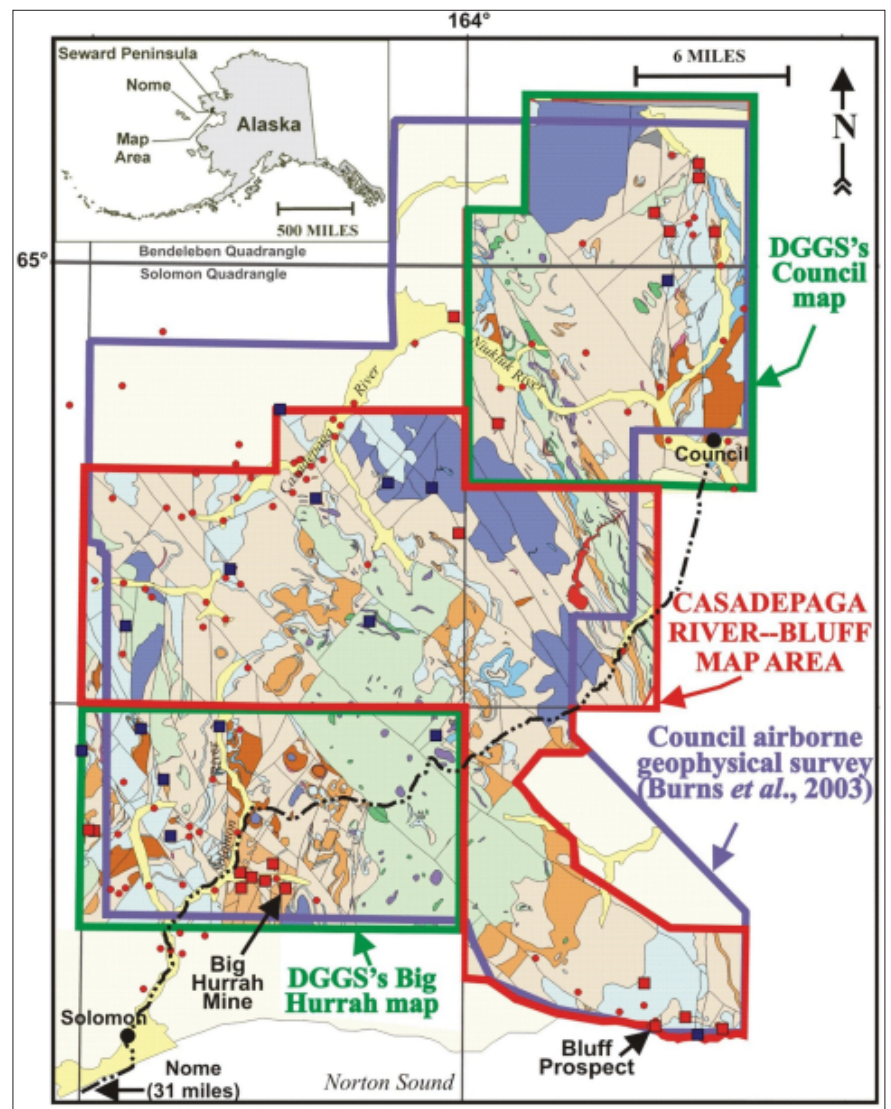
potential of the Nome Group for hosting basemetal sulfide deposits.

In the Casadepaga River-Bluff area, DGGS's geologic mapping and associated studies have documented the location, geochemistry, age, distribution, orientation, and regional structural controls on the area's gold-bearing quartz vein systems. To help predict where additional veins may be located, it is important to determine the timing of gold-vein formation relative to structural features, metamorphic events, and igneous intrusions. Our preliminary work indicates that Nome Group rocks underwent high-pressure blueschist-facies metamorphism 200 million years ago, and were later partially overprinted by a greenschist-facies mineral assemblage. Rare, extension-related alkalic intrusions of Cretaceous to Quaternary age are scattered throughout the map areas, but are not spatially associated with gold-bearing quartz veins. These veins yield ${ }^{40} \mathrm{Ar} /{ }^{39} \mathrm{Ar}$ adularia and white mica ages of 105 to $115 \mathrm{Ma}$. Hydrothermal kaolinite, cinnabar, and adularia indicate epithermal-style mineralization on the southern Seward Peninsula, as well as the more widely distributed, gold-bearing veins of possible orogenic or extensional origin. 


\section{BEDROCK GEOLOGY \& MINERAL-RESOURCE ASSESSMENT ALONG THE PROPOSED GAS PIPELINE CORRIDOR FROM DELTA JUNCTION TO THE CANADA BORDER}

The Alaska Highway is the primary land transportation route to interior Alaska from the contiguous United States, and is likely to become the locus of increasing development, especially if the proposed natural gas pipeline or Alaska Railroad extension are constructed along this route. Despite the corridor's strategic location, relatively little geologic and geotechnical work has been published along its length. This multi-year project, primarily supported by State Capital Improvement Project (CIP) funds, will provide a framework of geologic data upon which engineering, design, and resource decisions may be evaluated for future development between Delta Junction and the Canada border. In 2006, as the first phase of this project, DGGS collected, interpreted, and published airborne geophysical data for a 16-mile-wide corridor centered on the Alaska Highway. The second phase of the project consists of mapping bedrock and surficial geology and evaluating geologic hazards and resources. The surficial-geology and geologic hazards parts of the project are described separately.

The bedrock portion of the project includes 1:63,360-scale bedrock geologic mapping and mineral-resource assessment work. In 2006 and 2007, DGGS conducted geologic fieldwork between Delta Junction and Dot Lake, in 2008 between Dot Lake and Tetlin Junction, and in 2009 between Tetlin Junction and the Canada border (fig. 1). Although centered on the Alaska Highway, most of the 2009 field area was inaccessible by road; access was provided by helicopter. The 2008 portion of the corridor is particularly significant because of its close proximity to the active Denali fault, approximately 25 miles to the southwest in the Alaska Range. DGGS determined the location and kinematics of many smallerscale faults related to the Denali fault system within the corridor, and this data will provide a better understanding of the history and potential impacts of these faults.

Our bedrock maps incorporate interpretations of DGGS's airborne magnetic and resistivity data, field data, and various scientific analytical data. The geophysical data is particularly valuable for interpreting the geology in areas covered by surficial deposits or vegetation. Preliminary results from 2009

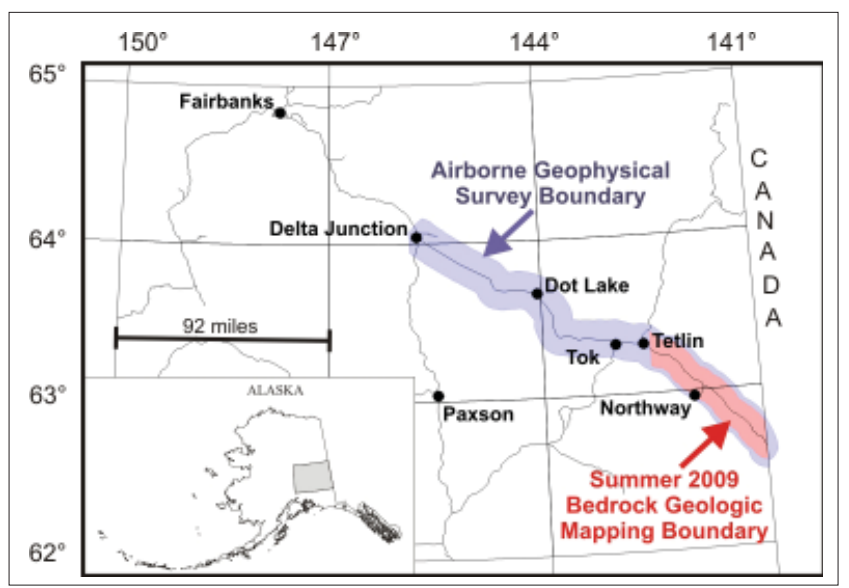
fieldwork show a continuation of geologic relationships determined by 2006-2008 fieldwork, along with new features and interpretations. Numerous plutonic rock suites were defined; these plutons intruded amphibolite-facies metasedimentary and metaigneous rocks similar to those elsewhere in the Yukon-Tanana Upland, as well as a suite of greenschist-facies metasedimentary rocks and metamafic intrusions, which likely correlate with similar units directly across the border in Canada.

These rocks have undergone several ductile to brittle deformation and faulting events. High-grade contractional ductile deformation affects rock units as young as Mississippian. Normal faulting, accommodating east-west extension, affects rock units as young as Late Cretaceous. Overprinting all of this is a complex system of numerous younger strike-slip, reverse, and oblique faults that have affected all of the rock units. These structures accommodate overall north-south contraction with a component of right-lateral slip, similar to deformation on the Denali fault. The latest structures may have been active during the Late Cenozoic, shown by their alignment with major topographic changes, and there are similar-azimuth lineations in young sedimentary units on aerial photographs and in DGGS's airborne-geophysical data. In addition, there is evidence of Quaternary-age faulting along the northern front of the Alaska Range (see p. 52).

DGGS is also evaluating the mineral potential of bedrock units by sampling and analyzing altered rocks to provide baseline geochemical data for use by State land-use planners and mineral exploration companies. Geochemical analyses for 2008 and 2009 fieldwork will be published in 2010. Bedrock geologic maps for the 2006-2009 corridor segments will be published in 2010 and 2011; funding for this planned work consists of FY2009 CIP funding and State General Funds. 


\section{ANNUAL ALASKA MINERAL INDUSTRY REPORT}

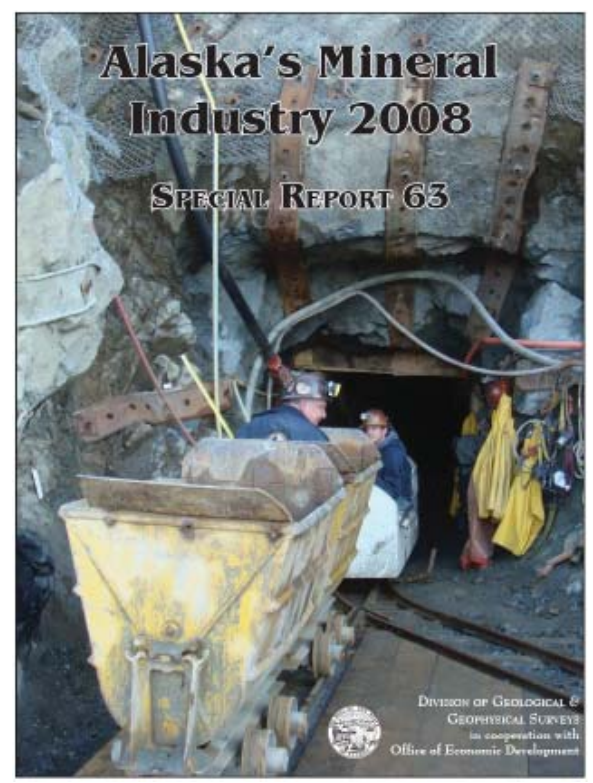

Alaska Statute 41.08 charges the Division of Geological \& Geophysical Surveys (DGGS) "to determine the potential of Alaska land for production of metals, minerals, fuels, and geothermal resources"; "shall conduct such other surveys and investigations as will advance knowledge of the geology of Alaska"; and "shall print and publish an annual report and such other special and topical reports and maps as may be desirable for the benefit of the state." To meet part of this goal, we gather, verify, collate, and supply statistics and summary observations about Alaska's mineral industry and release this information in a timely manner to the public in the format of an annual mineral industry report, an interim summary, and public presentations. This project supplies information to the mineral industry, provides the State and the public with valuable data pertaining to the health of Alaska's mineral industry, and fosters a better understanding of the significance of the mineral industry to Alaska's private sector and government.

The annual Alaska mineral industry report is a key source of information about exploration, development, and production of Alaska's mineral resources. Statewide and international circulation of the report and its findings at professional mineral industry conventions and trade shows, at chambers of commerce and other organizations' meetings, and in professional journals informs the general public, local and international mineral industry, and local, state, federal, and international government agencies about current activities within Alaska's mineral industry. The report serves as a barometer for the mineral industry's status in any given year and provides unbiased, authoritative information compiled in a consistent format from year to year. Government personnel rely on the report as an essential tool for formulating public policy affecting resource and land management.

The 2008 Alaska mineral industry report, released in November 2009, summarizes information provided through replies to questionnaires

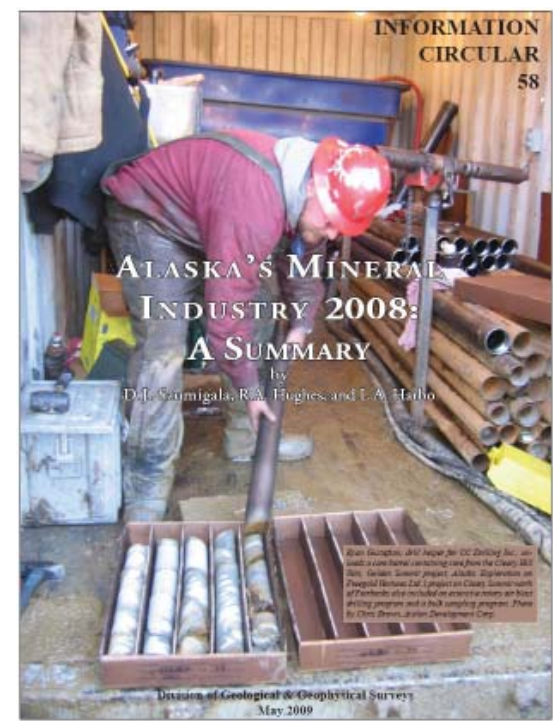
mailed by DGGS, phone interviews, press releases, and other information sources. The 2008 cumulative value of Alaska's mineral industry, the sum of exploration, development, and production values, was $\$ 3.171$ billion; $\$ 844$ million lower than 2007's record of $\$ 4.015$ billion. This was the third consecutive year that the cumulative value topped \$3 billion and the 13th straight year that Alaska's mineral industry topped \$1 billion. Exploration expenditures for 2008 were $\$ 347.3$ million, the highest expenditure total in 50 years of record keeping; development expenditures amounted to $\$ 396.2$ million, the second highest total since record keeping started in 1981; and the value of mineral production was $\$ 2,427.1$ million, the third highest total value. The Alaska mineral industry value will likely be lower in all categories in 2009 due to the worldwide economic downturn and reduced metal prices for the first part of the year.

The annual mineral report has been published for 27 consecutive years as a cooperative venture between the Department of Natural Resources' (DNR) Division of Geological \& Geophysical Surveys, and the Office of Economic Development (OED) in the Department of Commerce, Community \& Economic Development (DCED). A summary of the 2009 Alaska mineral industry activities will be released by February 2010. The 2009 Alaska mineral industry report will be released by early November 2010 .

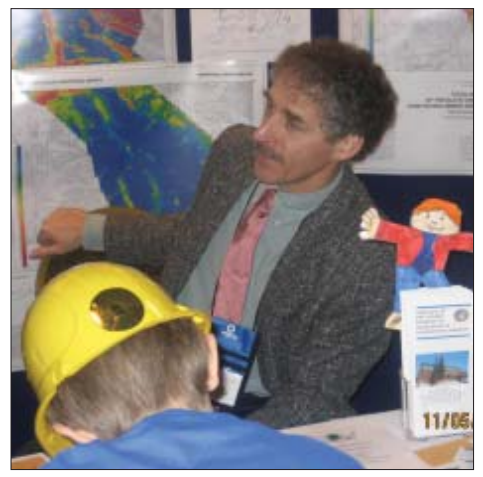




\section{ALASKA GEOLOGICAL AND GEOPHYSICAL MAP INDEX}

In 2003 the Alaska Department of Natural Resources, Division of Geological \& Geophysical Surveys (DGGS) and Land Records Information Section (LRIS) released the first version of a Web application that will ultimately provide the locations and outlines of Alaska geologic maps from all government agencies in a single, interactive, Internet-accessible location. The "Alaska Geology Map Index” site (http://maps.akgeology.info/) currently contains about 300 citations and outlines for DGGS-authored geologic maps. About 900 additional geologic map outlines and associated bibliographic references have been compiled and are being categorized and checked for errors during 2010 and 2011. Outlines for most Alaska 1:250,000- and 1:63,360-scale geologic maps produced by the U.S. Geological Survey (USGS) and additional DGGS maps will be added to the Map Index database in 2010. DGGS intends to add outlines for remaining geologic maps by DGGS, USGS, U.S. Bureau of Mines (BOM), and U.S. Bureau of Land Management (BLM) and geophysical maps by DGGS and other agencies in future years.

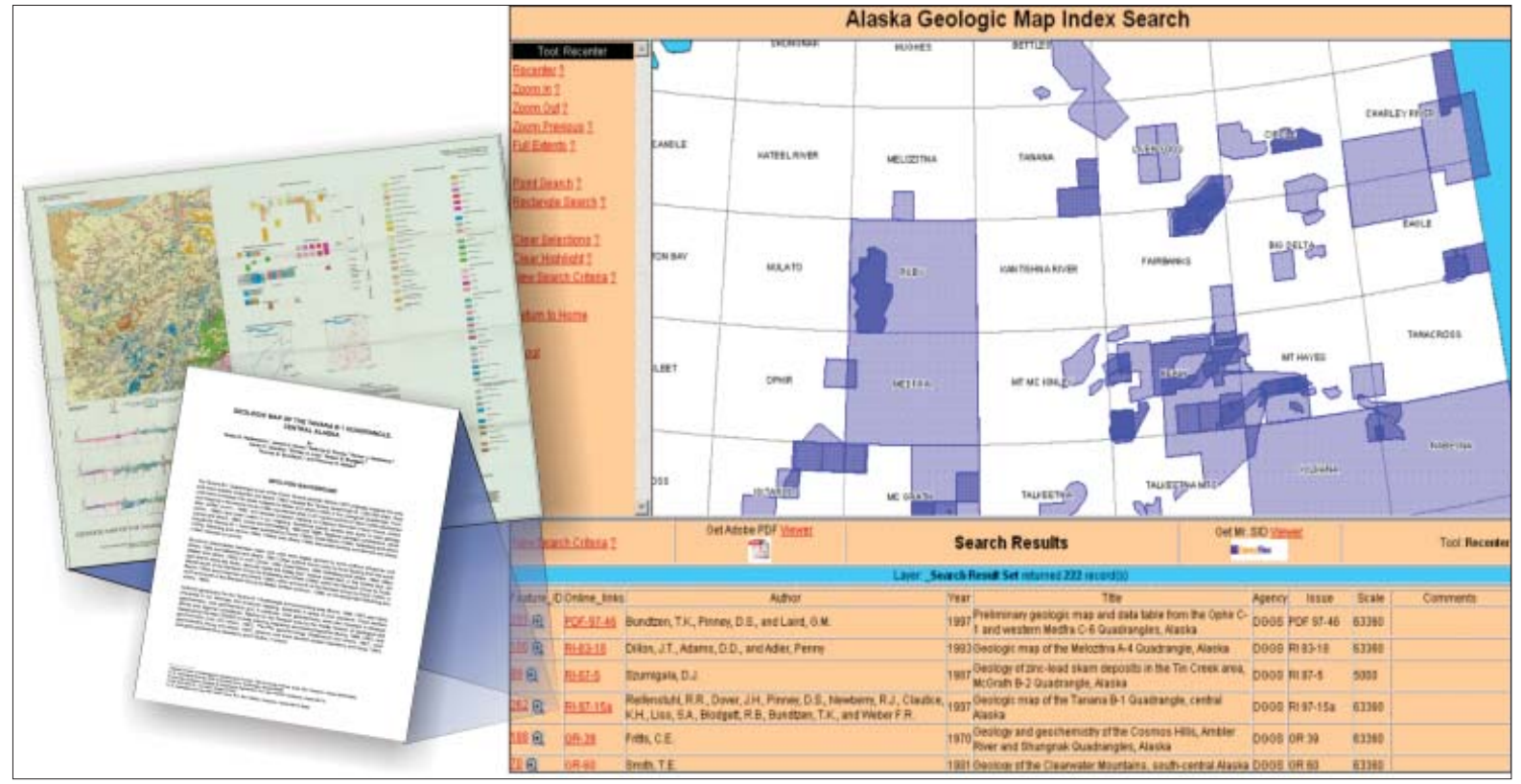

Currently, no up-to-date map index of DGGS, USGS, BLM, and BOM Alaska geologic maps exists. Internet access to the current status of geological and geophysical maps of Alaska will make it easier for the public and government agencies to more quickly find the maps they need to make informed resource- and land-management decisions. The categorized database provides an effective means of searching for maps of particular interest. For example, geologic hazard-related maps will be harvested from the Map Index database to help create the comprehensive map-based interface "Online Guide to Geologic Hazards in Alaska." This project is described separately under the Alaska Coastal Management Program (p. 48).

DGGS anticipates upgrading the Map Index interface to a fully integrated map- and text-based search application. The user will be able to: (1) retrieve subsets of map outlines on the basis of map categories (bedrock geology, surficial geology, resources-metals-lode, hazards-permafrost, etc.) or metadata (scale, publishing organization, publication date, etc.); (2) view the results in an interactive map interface and listing; and (3) re-query the results by either a text search or map selection. The interface will also provide links to downloadable digital reports and maps for each citation, where available. Some of these functions are available at this time, but the capability of the interface and number of maps available will be greatly improved.

The project was initiated with funding from the Federal Minerals Data and Information Rescue in Alaska (MDIRA) program and is now supported by State General Funds. The primary objective of the MDIRA program was to ensure that all available Alaska mineral data are preserved in a safe and readily accessible format for all potential users. 


\section{GEOCHRONOLOGIC DATABASE FOR ALASKA}

In 2005, the Alaska Division of Geological \& Geophysical Surveys (DGGS) initiated development of a comprehensive geochronologic database for Alaska. The geochronologic database contains summary interpretive and detailed analytical data and associated information for all available radiometric ages of rocks and minerals in Alaska. The objective of this project is to expand the most-current existing compilations of radiometric data and to make this age information widely accessible to private industry, academia, and government. This project was initially funded through the Federal Minerals Data and Information Rescue in Alaska (MDIRA) program and is now supported by State General Funds and the National Geological and Geophysical Data Preservation Program (NGGDPP). The primary objective of the MDIRA program is to ensure that all available Alaska minerals data are securely archived in perpetuity and in a format readily accessible by all potential users. Information on mineral resources is important for management policy decisions in both the public and private sectors. Increased use of high-quality data should lead to better economic, legislative, and environmental decisions.

The compilation includes information for all available U-Pb, K-Ar, ${ }^{40} \mathrm{Ar} /{ }^{39} \mathrm{Ar}$, and Rb-Sr ages of Alaska samples. Radiometric ages are compiled from both published and unpublished sources. Essential basic supporting information that is currently not easily accessible was harvested from original publications, student theses, industry records, and laboratory archives. This detailed information includes raw analytical data, standards, constants used in calculations, analytical laboratory, analyst, sample preparation and processing steps, sampling agency and geologist, and sample context and descriptions. To date, more than 4,925 age records have been compiled.

In 2009, DGGS's central Oracle database was populated with the compiled geochronologic data. Current efforts include documentation of data fields and creation of record-level metadata. DGGS has created a beta-version Web Feature Service (WFS) to serve age sample locations, basic metadata, and references to the appropriate original publications out to the public. The WFS data will be available from the National Digital Catalog (http://datapreservation.usgs.gov/catalog.shtml), and will be directly importable into Geographic Information Systems (GIS) software. In spring 2010, DGGS anticipates upgrading the WFS with summary age data and publishing a report of all summary geochronologic data in the central database. The final stage of the geochronology project will be to make these data fully accessible via an interactive, map- and text-based search application on DGGS's website and through a link on the MDIRA website (http://akgeology.info). DGGS's central database will serve as a repository for future Alaska radiometric data and provide an authoritative, up-to-date, digital source of this important geologic information.

Age spectra plot generated from detailed ${ }^{40} \mathrm{Ar} /{ }^{39} \mathrm{Ar}$ age data stored in the geochronologic database.

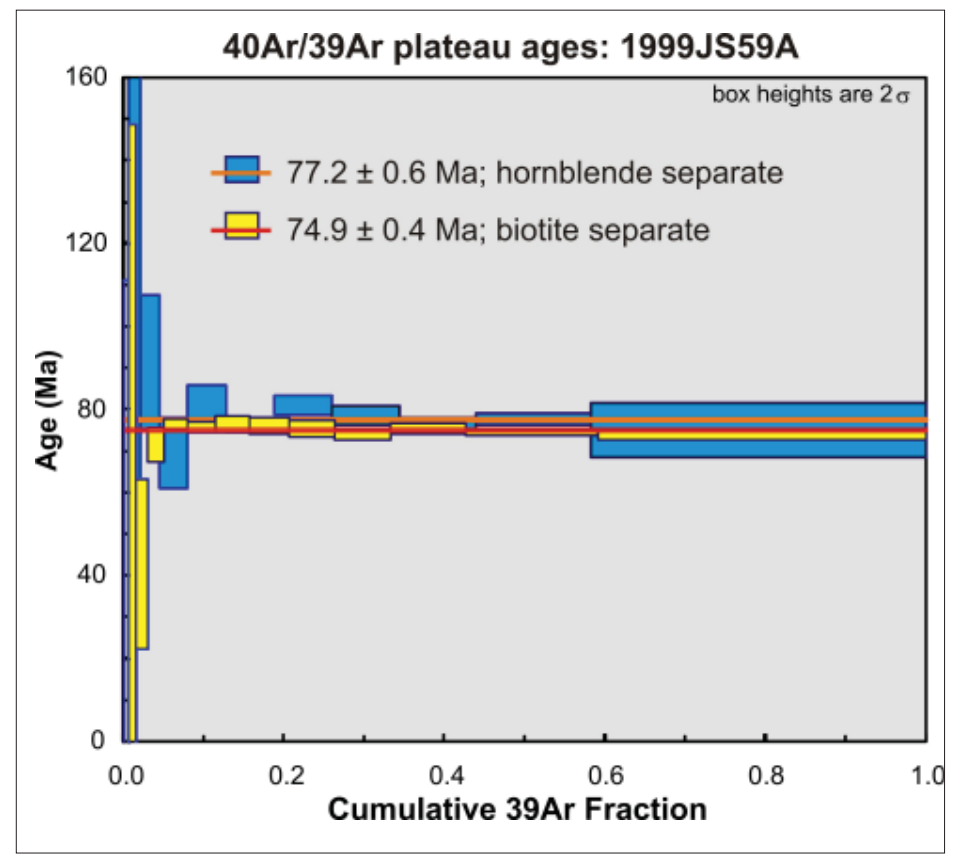

Table 1. Example summary table information for an ${ }^{40} \mathrm{Ar}{ }^{\beta 9} \mathrm{Ar}$ sample.

\begin{tabular}{|l|l|l|l|l|l|l|l|l|l|l|}
\hline $\begin{array}{l}\text { Analytical } \\
\text { Method }\end{array}$ & $\begin{array}{l}\text { Sample } \\
\text { Number }\end{array}$ & Latitude & Longitude & $\begin{array}{l}\text { Estimated } \\
\text { Location } \\
\text { Error }\end{array}$ & Age & Lithology & $\begin{array}{l}\text { Dated } \\
\text { Material }\end{array}$ & $\begin{array}{l}\text { Age } \\
\text { Interpretation }\end{array}$ & Age Type & Citation \\
\hline 40Ar/39Ar & $1999 J 559 A$ & 62.3 & -149.13 & & $77.2 \pm .6 \mathrm{Ma}$ & quartz diorite & $\begin{array}{l}\text { mineral } \\
\text { separate: } \\
\text { hornblende }\end{array}$ & $\begin{array}{l}\text { igneous } \\
\text { crystallization }\end{array}$ & plateau & PIR 2002-4
\end{tabular}




\section{ALASKA COASTAL MANAGEMENT PROGRAM: NATURAL HAZARDS}

DGGS provides support to Alaska Coastal Management Program (ACMP) personnel and coastal district planners regarding natural hazard issues. DGGS responsibilities include: Reviewing natural hazard aspects of proposed coastal projects during the consistency review process; recommending state designation of hazard areas during consistency reviews when needed; providing support to coastal district planners in revising coastal management plans; participating in district teleconferences; and periodically reviewing regulatory and planning documents regarding natural hazards issues.

A lack of basic field data and baseline information on geologic hazards in Alaska makes it difficult for coastal districts and the State to implement the ACMP natural hazard standard (11 AAC 112.210). Coastal districts often do not have the scientific information needed to designate natural hazard areas in their district plans for the purpose of ensuring that coastal development adequately mitigates the risks of the hazards. During consistency review for a proposed project, the State can, under the standard, designate a natural hazard area so that hazards risks may be addressed in the review. DGGS assists DNR in development of the background information and formal designation of the hazard area. The ACMP is currently undergoing re-evaluation, which may require DGGS participation in revision of the natural hazards standard.

The DGGS website provides access to the online Guide to Geologic Hazards in Alaska, a bibliographic database with links to scanned maps and documents published by DGGS and the U.S. Geological Survey (USGS) containing information relevant to hazard identification in Alaska. The guide is served from DGGS's publications database and is searchable by coastal district at http://wwwdggs.dnr.state.ak.us/geologic_hazards_coastal_districts. htm. DGGS was recently awarded 309 Enhancement Grant funding to update the guide and make it more userfriendly to coastal district planners, ACMP, and project applicants. The revised online guide will facilitate deliv-

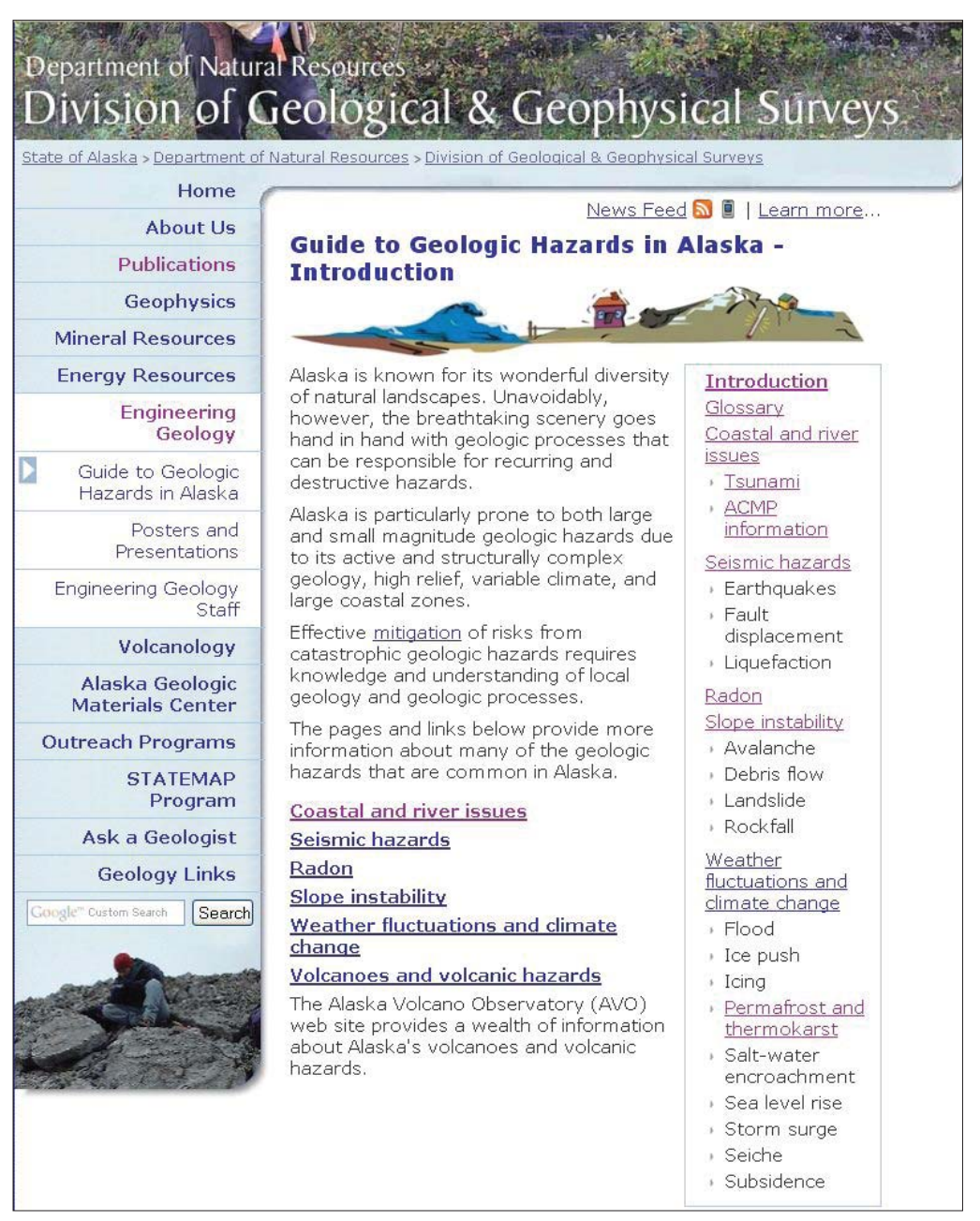

ery of new geologic hazard maps and reports planned by DGGS under the Coastal Impact Assistance Program (CIAP; described on p. 50) and recommended by the Climate Change Cabinet's Immediate Action Workgroup. The upgraded Guide to Geologic Hazards in Alaska will act as a resiliency tool, providing districts centralized data that can support proposed natural hazards designations and policies, planning, and federal reporting on natural hazards. The upgrade plan includes incorporating the geographic extents of published hazards data, collected in part from the DGGS Map Index project (described on p. 46), to develop a functional prototype of an interactive geologic hazards bibliography map using the State's AlaskaMapper interface or a GoogleEarth-based alternative.

Figure 1. The DGGS online Guide to Geologic Hazards in Alaska is being updated to include relevant new published information and internet sites. The guide will also be enhanced by the addition of a searchable map interface that will allow users to more easily identify bibliographic resources available for their area of interest. 


\section{ASSESSMENT OF GEOLOGIC HAZARDS ASSOCIATED WITH CLIMATE CHANGE}

Alaska's high latitude makes it particularly sensitive to the effects of a changing global climate. This sensitivity has led such widely-read national publications as USA Today to call Alaska the 'poster state' for climate concerns. Many believe these climate changes will have a direct effect on Alaska communities and infrastructure, as well as on the livelihoods and lifestyles of Alaskan citizens, through increased geologic hazards such as coastal and riverbank erosion, flooding, and thawing permafrost. Although some effects of these processes on man-made structures may be due to improper design and not climate change, studies have shown that permafrost near the current southern margin of its extent is degrading, and that a northward shift of hundreds of kilometers is anticipated in this boundary if climatic warming trends continue. As early as 1998, the Bering Sea Impact Study (BESIS) evaluated the economic impact and consequences of global climate change on Alaska's infrastructure as part of the U.S. National Assessment and concluded that "much of the damage to infrastructure... — roads, transportation, etc.-could be avoided through adequate planning and public policy.” It is important that the State help preserve the health and safety of Alaska's people by being prepared for potential emergency situations resulting from geologic hazards that are caused or amplified by climate change, and to perform the necessary sound science to identify high-risk areas where proactive mitigation efforts will be needed and useful (fig. 1). These new data will also be critical to identify areas where proper structure design and informed planning can alleviate the need for future mitigation.

The Division of Geological \& Geophysical Surveys (DGGS) has begun a focused effort to prioritize, map, and publish geologic-hazards information that will be used for proactive planning, mitigation, and emergency response in high-risk communities and developing areas. This effort will be guided by priorities set forth by the Immediate Action Work Group (IAWG) of the Governor's Subcabinet on Climate Change, as well as by consultation with state agencies and affected communities, and will provide valuable information to allow planners and design engineers to minimize the economic impacts and public safety risks associated with geologic hazards.

DGGS will collect the necessary field data to produce and publish peer-reviewed surficial and geologic-hazards maps and reports of high-risk Alaska communities. Maps may include proposed community relocation sites, and will be completed at local and/ or regional scales as needed to address specific local problems and to understand and evaluate the larger geologic context. The geologic-hazards maps will be published in digital GIS format in conformance with national standards and will delineate areas where potential natural hazards such as erosion, slope instability, flooding, and thawing permafrost should be considered at a more detailed level to fully evaluate risk for any given use. DGGS expects to complete the first products of this project in FY2011.

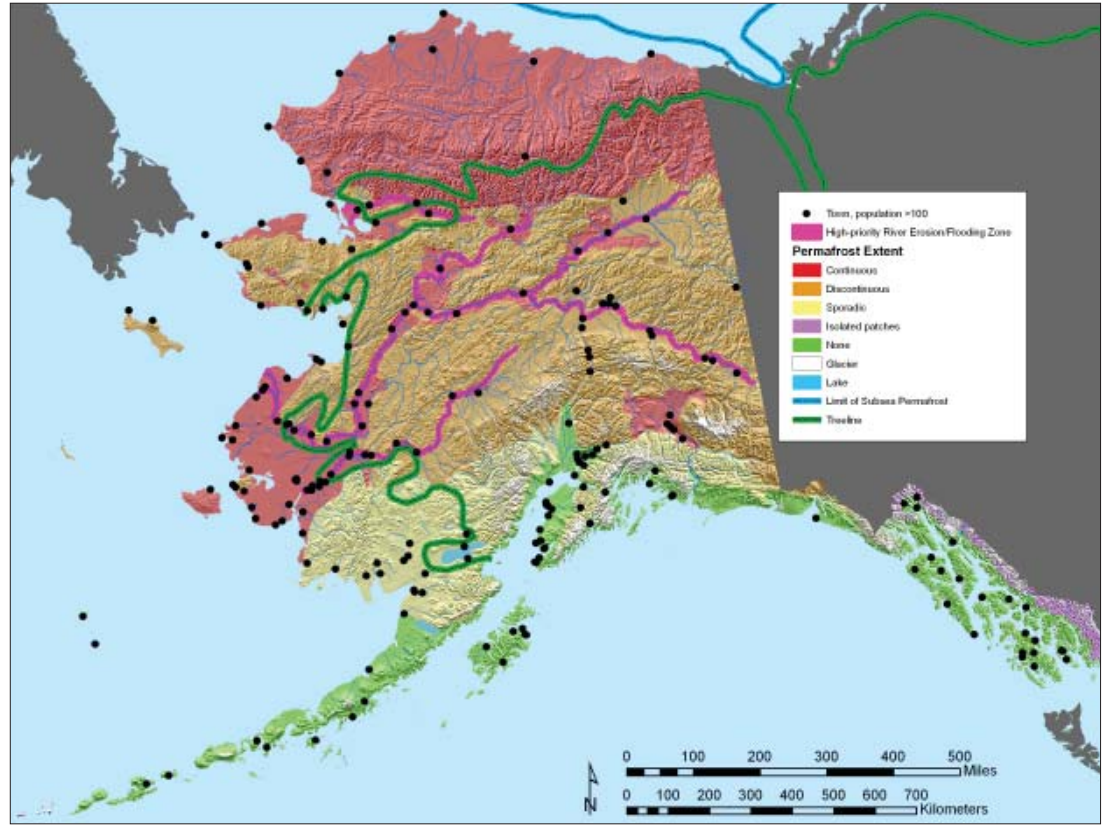

Figure 1. Map showing the distribution of permafrost and major river erosion and flooding zones in Alaska with respect to communities with populations of greater than 100 people. Along with coastal flooding and erosion, these natural processes and phenomena are likely to be affected or amplified by climate change. 


\section{GEOHAZARD EVALUATION AND GEOLOGIC MAPPING FOR COASTAL COMMUNITIES}

Approximately 6,600 miles of Alaska's coastline and many low-lying areas along the state's rivers are subject to severe flooding and erosion. The United States General Accounting Office (GAO; now the U.S. Government Accountability Office) reported in 2004 that flooding and erosion affects 184 out of 213 (86 percent) of Alaska Native villages, and most of these are coastal communities (fig. 1). Many of the problems are long-standing, although some studies indicate that increased flooding and erosion is being caused in part by changing climate. These findings were reinforced in 2006, when the U.S. Army Corps of Engineers determined that the coastal villages of Kivalina, Newtok, and Shishmaref have only 10-15 years left in their current locations before being irretrievably lost to erosion if countermeasures are not implemented. The Immediate Action Work Group (IAWG) of the Governor's Subcabinet on Climate

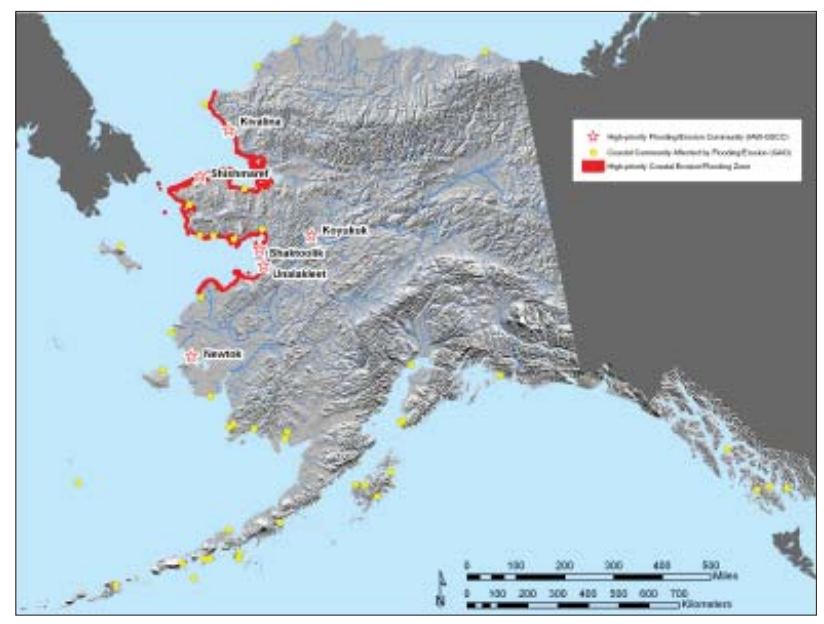

Figure 1. Map showing the distribution of Alaska communities at risk for coastal flooding and erosion. Change made a series of recommendations in 2009 that represent an intensive collaborative effort undertaken in an open public forum to address the immediate needs of the State, with a specific focus on six communities in peril: Newtok, Shishmaref, Kivalina, Koyukuk, Unalakleet, and Shaktoolik (fig. 2). Of the top six at-risk villages, four are located on the coast.

In response to these issues, DGGS is initiating a coastal community geohazards evaluation and geologic mapping program in support of community and district planning. External support for this effort comes from the federal U.S. Minerals Management Service (MMS) as part of the Coastal Impact Assistance Program. Beginning in summer 2010, we will collect the necessary field data to produce and publish surficial and engineering-geologic/hazards maps of Alaska coastal communities, prioritized in consultation with the IAWG, Alaska Division of Community and Regional Affairs, Alaska Coastal Management Program staff, U.S. Army Corps of Engineers (COE), and affected coastal districts. The maps will identify local geologic hazards, engineering-geologic conditions, and potential construction-materials sources that must be considered in the siting, design, construction,

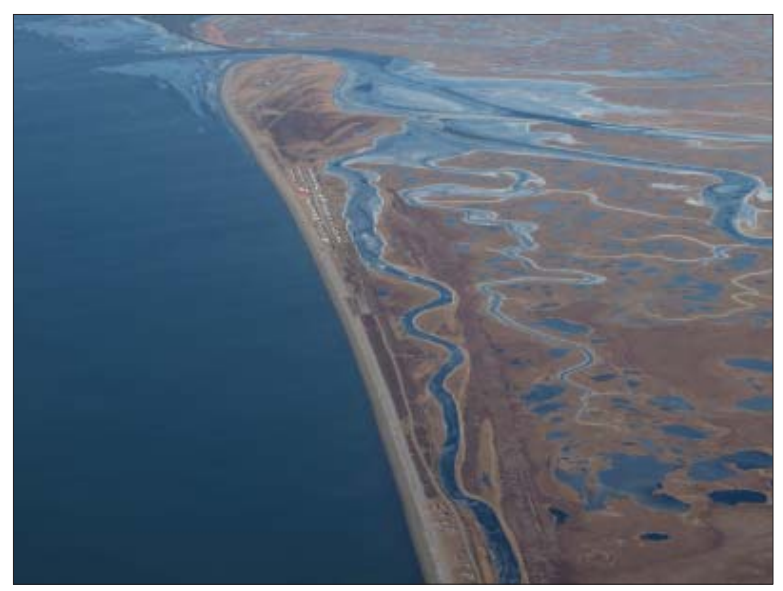

Figure 2. The village of Shaktoolik, northwestern Alas$\mathrm{ka}$. The berm between the town and the beach is composed largely of naturally deposited driftwood logs. Shaktoolik becomes an island during storm surges, and then it is additionally threatened by ocean waves throwing these logs into town. and operations of development projects to ensure protection of human life, property, and the coastal environment. Maps may include proposed relocation sites in response to the severe coastal erosion problems now facing various Alaska communities. Mapping will be completed at local and/or regional scales as needed to address specific local problems and to understand and evaluate the larger geologic context of the area. The engineering-geologic/hazards maps will be published in GIS format with standard metadata and will delineate areas where natural hazards such as erosion, slope instability, active faults, flooding, and earthquake effects should be considered at a more detailed level to fully evaluate construction risk and to ensure that the coastal areas are not damaged by planned and proposed development. Project work will be coordinated with current U.S. Geological Survey coastal studies to ensure there is no duplication of effort. DGGS expects to complete the geohazard evaluation and hazard mapping for one community in FY2011 and one or two communities in each of the following three years. 


\section{GEOLOGIC MAPPING AND HAZARDS EVALUATION IN AND NEAR KIVALINA, NORTHWESTERN ALASKA}

Approximately 10,600 kilometers of Alaska's coastline and many low-lying areas along the state's rivers are subject to severe flooding and erosion. The United States General Accounting Office (GAO; now the U.S. Government Accountability Office) reported in 2004 that flooding and erosion affects 184 out of 213 (86 percent) of Alaska Native villages. These findings were reinforced by subsequent studies, conducted by the U.S Army Corps of Engineers (2006) and the Immediate Action Workgroup of the Alaska Governor's Subcabinet on Climate Change (2008), which identified a number of communities as being in greatest peril resulting from climate change phenomena and therefore in most need of immediate actions to prevent loss of life and property.

DGGS has statutory responsibility to perform

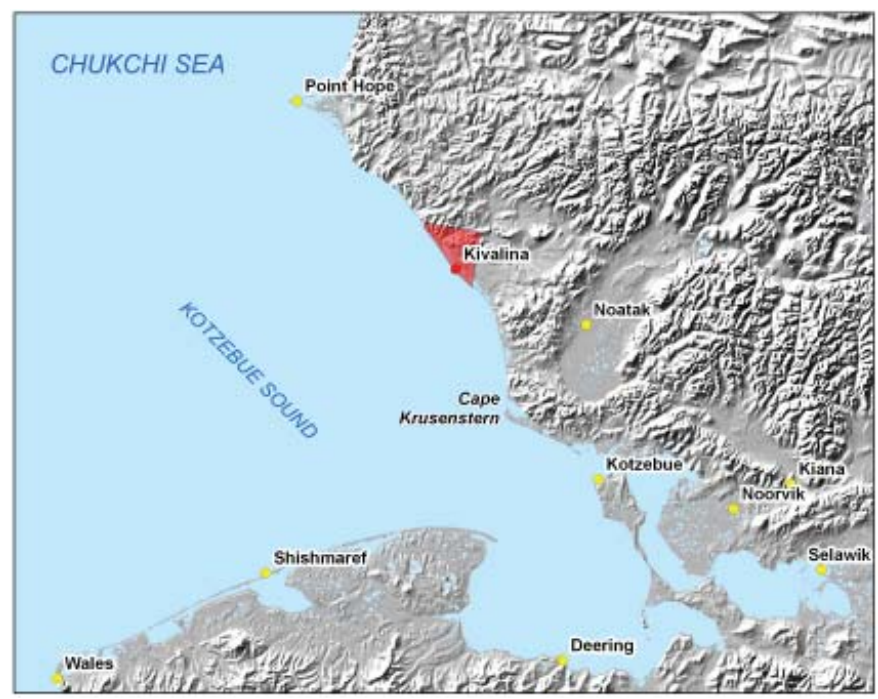

Figure 1. Location of the proposed Kivalina map area. the necessary sound science to identify high-risk areas where proactive mitigation efforts will be needed and useful. For FY10, Alaska's Geologic Mapping Advisory Board (GMAB) endorsed DGGS's choice of the high-risk community of Kivalina (fig. 1) as a STATEMAPfunded project to map surficial geology and assess geologic materials and natural hazards in support of informed community planning to deal with the severe flooding and erosion (fig. 2).

The objectives of the 2010 Kivalina STATEMAP project are: (1) Map the surficial geology in sufficient detail to develop comprehensive lithologic unit descriptions and a geomorphic framework that can be used to understand the active earth processes affecting the village of Kivalina and the surrounding area; (2) map the bedrock geology at a reconnaissance level sufficient to evaluate the lithologies for general engineering characteristics; (3) develop information matrices and derive maps that describe the general engineering properties of bedrock and unconsolidated geologic units in the map area; and (4) identify and map potential geologic hazards, including areas of flooding, erosion, thawing permafrost, and slope instability.

Mitigation of the impacts of flooding and erosion, both in the short and long term, may range from simple beach armoring to construction of elaborate erosion-control structures to complete relocation of the entire settlement. These new data will be critical to community planners as they develop and administer their plans in the context of these major undertakings.

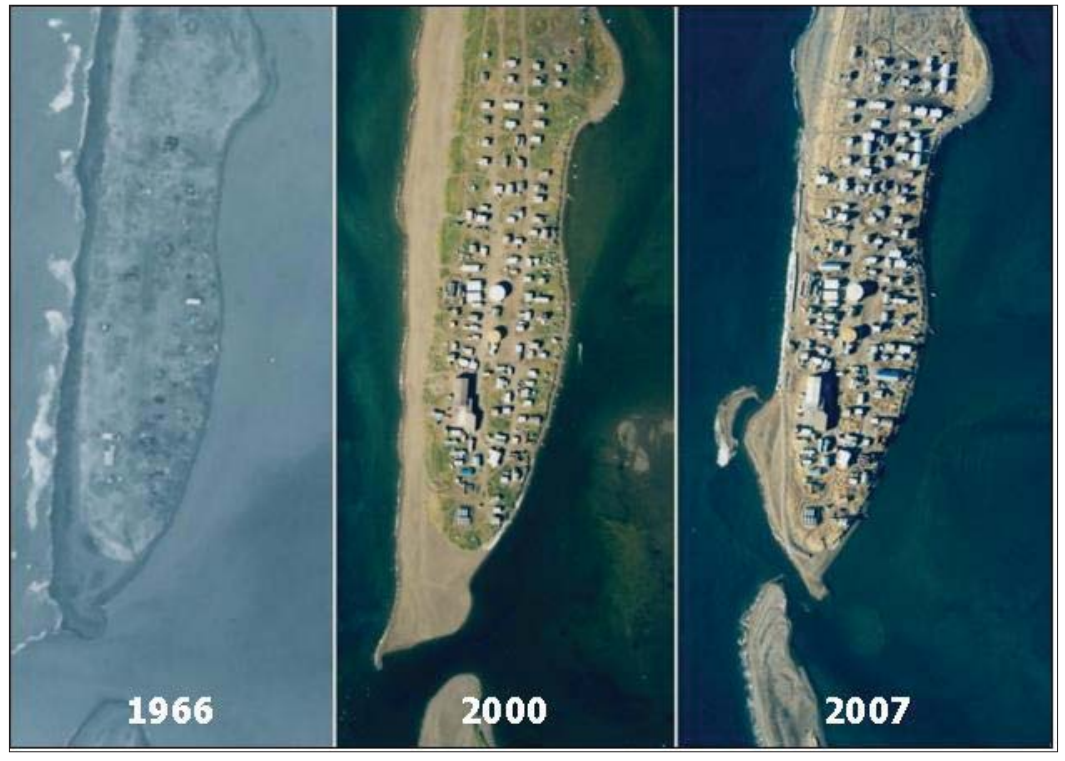

Figure 2. Coastal erosion poses a severe hazard to the village of Kivalina. These aerial images document the magnitude of change in the coast's configuration, and increasing threat to the community, over the last 40 years. The 2000 and 2007 images document the accelerated effects of these processes during the most recent decade. 


\section{GEOLOGY, GEOHAZARDS, AND RESOURCES ALONG THE PROPOSED GAS PIPELINE CORRIDOR, ALASKA HIGHWAY, FROM TETLIN JUNCTION TO THE CANADA BORDER}

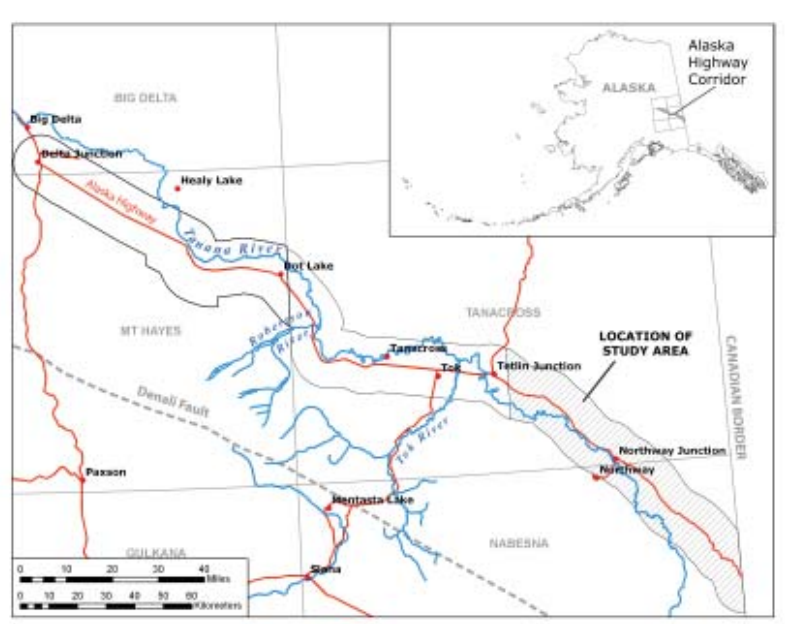

Figure 1. Location of the Dot Lake to Tetlin Junction map area.
The Alaska Division of Geological \& Geophysical Surveys (DGGS) has been conducting a multi-year project to evaluate the geology, geohazards, and material resources in a 12-mile-wide corridor centered along the Alaska Highway between Delta Junction and the Canada border. This effort is largely in preparation for the proposed natural gas pipeline, so that baseline geologic data are publicly available on which preliminary decisions can be made. Current and past work has focused on preparation of surficial-geologic maps, engineering-geologic maps, permafrost maps, bedrock-geologic maps and reports discussing potentially active faults in this region. The bedrock mapping effort is described separately (see p. 44).

In response to strong public interest in this project, DGGS held an open workshop in May 2009 to discuss preliminary findings from 2007 and 2008 fieldwork. The workshop brought together more than 30 people, including representatives from consulting companies, pipeline companies, oil and gas companies, and government agencies as well as Native and academic organizations. Discussions and response from those attending the workshop indicate this work has importance far beyond the proposed natural gas pipeline.

During the summer of 2009, DGGS continued to conduct fieldwork along the Alaska Highway, focusing on the corridor segment between Tetlin Junction and the Canada border (fig. 1). Work included refining preliminary surficial and permafrost maps that were based on spring 2009 interpretation of aerial photography, and investigating lineaments in and near the corridor for evidence of recent fault activity.

Our investigation of active and potentially active faults failed to identify conclusive evidence of recent faulting east of Tetlin Junction, although several suspicious lineaments described in 1970s-era reports were examined in the field. Surficial-geologic and permafrost investigations reveal the area is dominated by well sorted wind-blown sands, including linear and parabolic dunes. Preliminary analysis indicates the frozen eolian sand has high moisture contents (generally

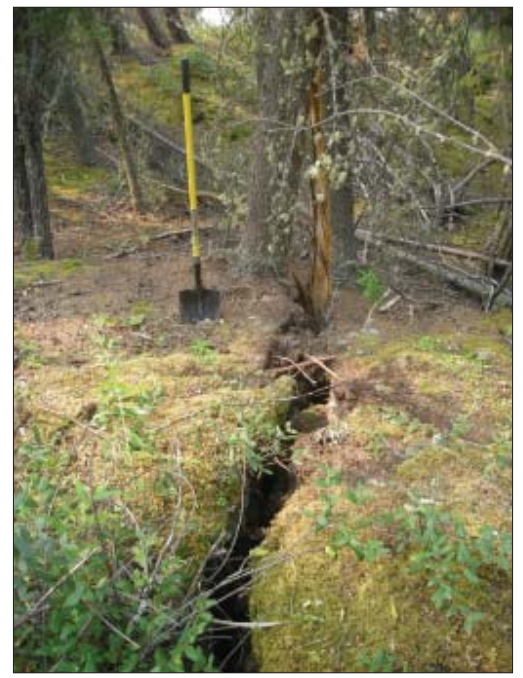

Figure 2. Ground cracking resulting from active slope movement south of the Alaska Highway near milepost 1267. between 20 and 60 percent), due to the ice content of the permafrost. Land surface disturbances and potential climatic warming could lead to melting permafrost, resulting in subsidence, slope failure, and/or reduced sediment strength, all significant hazards that should be considered prior to construction in the area. The southeastern part of the map area is a broad lowland area dominated by fine-grained deposits and numerous lakes along the Chisana and Nabesna rivers, where permafrost is thought to be extensive. South of the Alaska Highway near milepost 1267 there is widespread evidence of active slope movement, probably related to melting permafrost (fig. 2). Such movement also is found in other areas, such as upper Gardiner Creek, and should be considered when assessing geologic hazards.

In addition to work in the Tetlin Junction-Canada border segment, we revisited field sites west of Tok to better define active faults south of the Alaska Highway, and revisited localities near the Tok fan to better understand the processes involved in fan development. Results from the Tok fan investigations were presented at the Geological Society of America National Meeting in Portland in October 2009.

Results of this summer's fieldwork will be published in 2010 as permafrost maps and reports, surficial-geologic maps and reports, and derivative engineering-geologic maps, all at a scale of 1:63,360. A report discussing active and potentially active faults in this region is also anticipated to be released in 2010 . 


\section{NEOTECTONIC MAPPING ALONG THE LAKE CLARK FAULT IN THE TYONEK AREA, WESTERN COOK INLET, ALASKA}

In conjunction with the 2009 Tyonek STATEMAP project (see p. 36), the Division of Geological \& Geophysical Surveys (DGGS) is conducting neotectonic mapping on the west side of Cook Inlet (fig. 1). The map area straddles the northwest margin of Cook Inlet basin, includes extensive exposures of Tertiary-age nonmarine rocks, and encompasses about 2,000 square kilometers (nearly 800 square miles) of State and Native corporation land. The Lake Clark fault is a right-oblique reverse fault that extends $\sim 170 \mathrm{~km}$ northeast from Lake Clark in the western Alaska Range to the northern Cook Inlet forearc basin. Post-Eocene right lateral and northside-up vertical displacements of $26 \mathrm{~km}$ and 500-1,000 m, respectively, are well documented. Details about the fault's Quaternary history are limited to only a few observations. The Castle Mountain fault has the same sense of motion as the Lake Clark fault, and continues to the northeast for an additional $\sim 140 \mathrm{~km}$. Previous paleoseismic studies along the Castle Mountain fault suggest four late Holocene surface ruptures and a late Pleistocene-Holocene slip rate of 2-3 mm/yr. Knowledge of the relative activity of Lake Clark fault, as well as understanding possible kinematic linkages between the Lake Clark and Castle Mountain faults, has important implications for estimating maximum earthquake rupture lengths and magnitudes for the Cook Inlet region. Thus, the focus of our 2009 field investigation was to evaluate the recency of activity along the Lake Clark fault by documenting the presence or absence of Quaternary tectonic features.

Collecting information on the relative age of surficial deposits was a critical first step in DGGS's evaluation of the history of the Lake Clark fault. This was carried out in conjunction with DGGS surficial-geologic mapping in the Tyonek area. We then performed ground and aerial reconnaissance

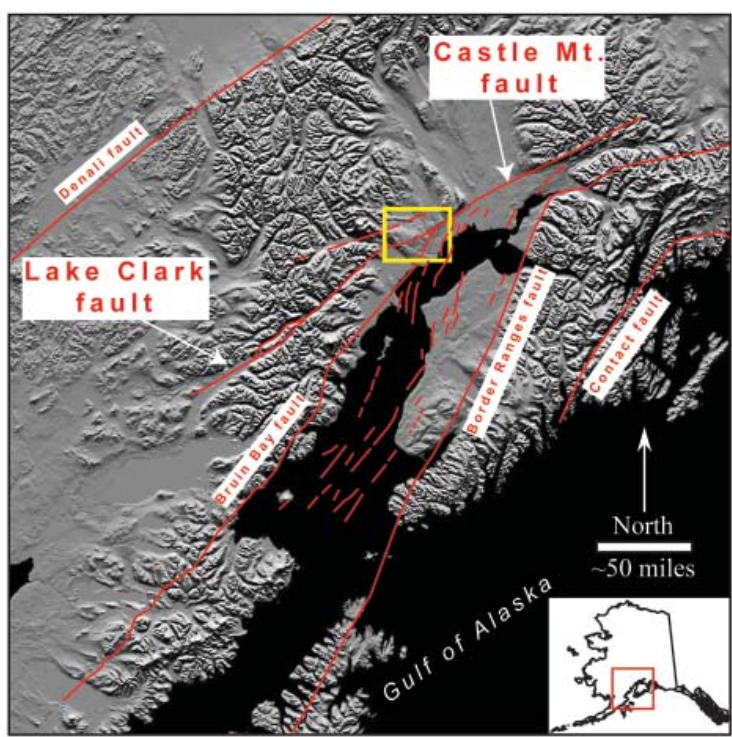

Figure 1. Map showing regionally significant faults in the Cook Inlet area. Yellow box indicates the area of new detailed neotectonic mapping along the northeastern part of the Lake Clark fault. luga River.

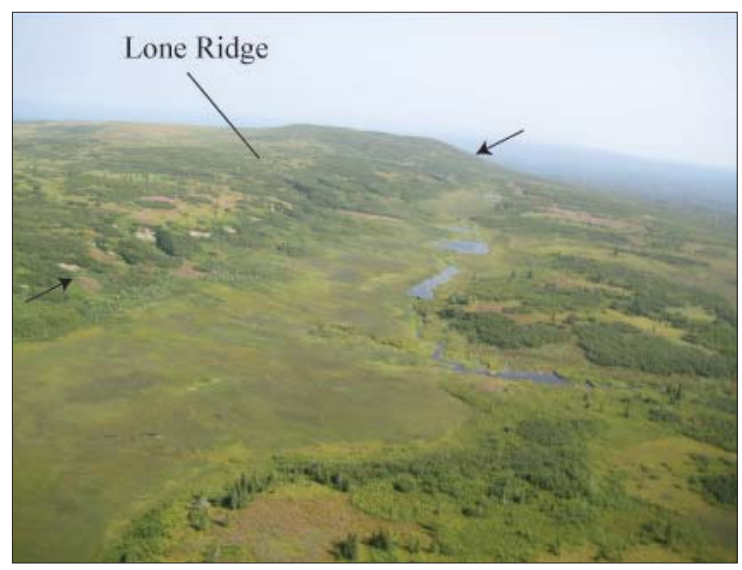

Figure 2. Photograph of 20-m-high fault scarp along the Lake Clark fault at Lone Ridge. Fault extends between arrows. White outcrops along the fault scarp are Cretaceous/Tertiary granite that has been juxtaposed against Tertiary sedimentary rocks. View to the northeast.
An approximately 5.5-km-long and 20-m-high escarpment in bedrock marks the trace of the fault along the southeast side of Lone Ridge (fig. 2). To the northeast, this scarp cuts preNaptowne-age ice marginal deposits (Marine Isotope Stage or MIS 6? deposits), and is truncated by the early Wisconsin Naptowne glacial ice limit $(\sim 21 \mathrm{ka})$. To the southwest, tectonic features are not preserved across MIS 4 glacial deposits ( $\sim 70 \mathrm{ka}$ ) due to either lack of preservation or lack of activity. Our preliminary mapping places broad constraints on the recency of activity along this portion of the Lake Clark fault. The results indicate that the eastern part of the fault is characterized by a relatively low rate of activity and has been tectonically quiescent since at least 21,000 years ago.

We plan to continue our investigation of the Lake Clark fault during the summer of 2010, including further refinement of our mapping, exploring dating options for the glacial chronology, and observation of the fault to the west in the Alaska Range. The data are important for seismic hazards assessments related to petroleum production infrastructure and potential future resource development in the Cook Inlet region, as well as seismic safety of the greater Anchorage metropolitan area. Our results will ultimately be incorporated into the Alaska Quaternary Fault and Fold database, planned for release in 2011. 


\section{PALEOSEISMIC STUDIES ALONG THE DENALI FAULT, MENTASTA-SLANA GEOPHYSICAL SURVEY TRACT}

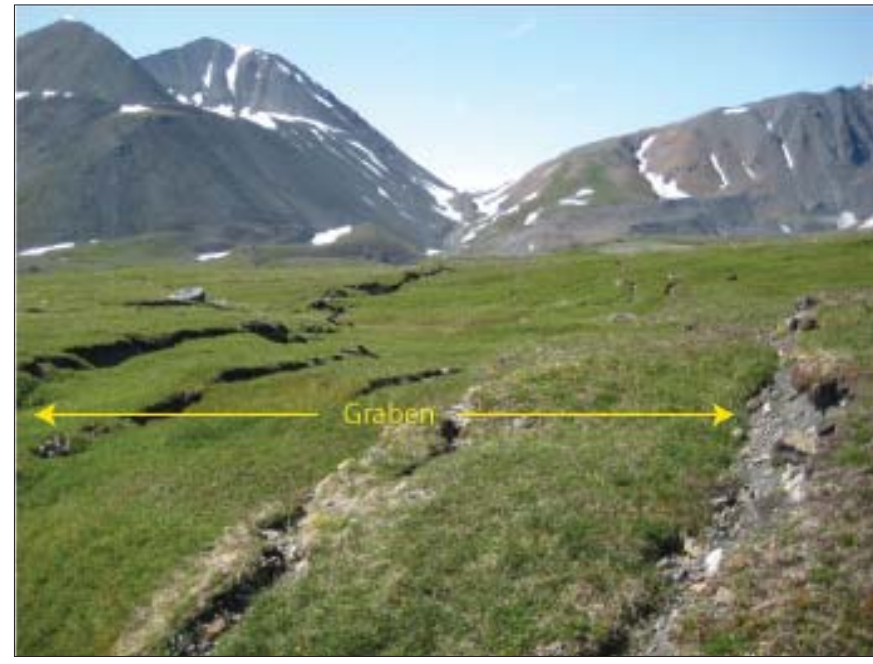

Figure 1. Graben formed along the 2002 Denali fault rupture trace in the vicinity of our 2009 paleoseismic study.

leoseismic trench study in the Chistochina Glacier area approximately $32 \mathrm{~km}$. was performed in the Mentasta-Slana geophysical survey tract, the focus of ongoing bedrock and Quaternary geologic mapping currently being conducted by DGGS as part of the federally funded STATEMAP program (described separately).

During the summer of 2009, we performed helicopter reconnaissance and field mapping along an approximately $14.5 \mathrm{~km}$ section of the 2002 Denali fault rupture trace to identify a suitable site for paleoseismic investigation. Stereo color-infrared aerial photographs (1:60,000 scale) were also used in site selection. In this area, the fault is a relatively simple linear fault trace, characterized by uphill- and downhill-facing scarps, right-laterally-displaced streams and glacial moraines, linear valleys, and local grabens (fig. 1). We hand excavated three trenches at the Slate Creek site where the fault traverses a subdued ground moraine. A sketch of the western wall of Trench SLC-T1 was logged at a scale of 1 in:0.5 m (fig. 2). The trench exposed glacial till overlain by a fining-upward section of gravel, sand, and silt. A total of six faults were identified, all of which break the entire stratigraphic section to the surface indicating rupture during the 2002 event (faults labeled F1-F6 on fig. 2). A peat deposit buried by fault-scarp-derived colluvium adjacent to fault F6 provides evidence for an earthquake (penultimate event) that predates the 2002 rupture. Preliminary radiocarbon analysis of this peat suggests that the penultimate event occurred between AD 1290 and 1400. Trenches SLC-T2 and SLC-T3 revealed a relatively thicker package of sediment overlying glacial till. Upward fault terminations indicate the occurrence of at least two paleoearthquakes. The lesser number of earthquakes observed in trench SLC-T1 is attributed to the lack of earthquake horizons due to minimal accumulation of sediments and/or repeated rupture along individual fault splays.

Analyses of radiocarbon samples collected in trenches SLC-T2 and SLC-T3 are still in progress and will ultimately provide the first paleoearthquake timing information on this section of the fault. We anticipate working closely with our USGS partners over the next year to develop an earthquake chronology based on the results from the three trenches. The data will be compared to paleoseismic histories determined at other sites along the central and eastern Denali fault, and ultimately be used to develop earthquake recurrence models for south-central Alaska. The information will also contribute to Alaska’s Quaternary fault and fold database.

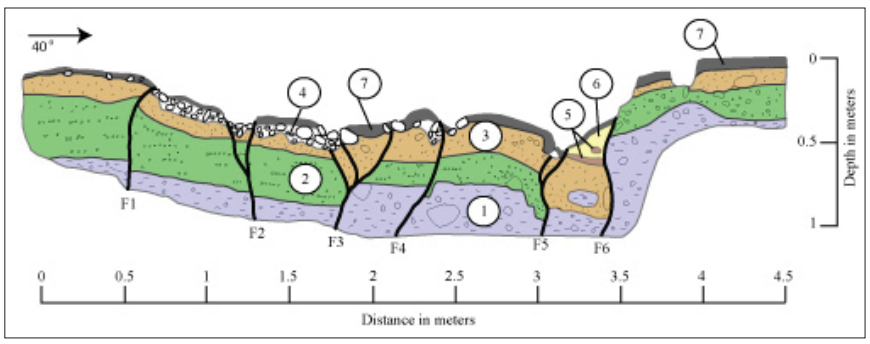

Figure 2. Stratigraphic log of a trench excavated across the Denali fault. Unit 1, glacial till; Unit 2, coarse sand and gravel; Unit 3 , fine sand and silt; Unit 4, angular cobbles; Unit 5, buried peat; Unit 6, scarp derived colluvium; and Unit 7, modern peat mat. 


\section{QUATERNARY FAULT AND FOLD DATABASE}

The Division of Geological \& Geophysical Surveys (DGGS) is continuing collaborative efforts with the U.S. Geological Survey (USGS) to develop a Quaternary fault and fold database for Alaska (fig. 1). A similar database currently exists for the lower 48 states and includes geologic, geomorphic, and geographic information for more than 2,000 faults and folds. This vast online resource is of great utility to the earthquake engineering community, the insurance industry, scientific researchers, and the general public. Although Alaska is one of the most seismically active states, information on Quaternary tectonics is sparse. The November 3, 2002, magnitude 7.9 Denali fault earthquake attests to the importance of information related to the location of past and future earthquakes (fig. 2).

DGGS has completed a comprehensive literature search for published materials on Quaternary faults and folds and is in the process of creating text-based descriptions for individual structures. Pertinent data summarized in these descriptions includes geographical information, geomorphic expression, length, average strike, sense of movement, age of faulted surficial deposits, existing paleoseismological studies, and a list of references. Additionally, DGGS is using a geographic information system (GIS) to digitize fault traces and fold axes at 1:250,000 scale with associated attributes according to national guidelines. After releasing the GIS database as a DGGS digital publication, it will be combined with the existing USGS Quaternary fault and fold database, which provides users with a powerful user-friendly map interface linked to the available data.

We expect to complete the digital map and have summaries of the most important structures by the end of 2010 . However, given the number of faults and lack of information on many structures, the complete dataset will take years to complete. Our initial effort will serve as a platform to record additional information as new faults are discovered and future detailed studies are performed.

In December 2009, DGGS geologists will meet with an international panel to discuss a common set of definitions, strategies, standards, quality criteria, and formats for the compilation of databases that will be used as input parameters to the global earthquake model (GEM). This model will serve as an independent standard to calculate and communicate earthquake risk worldwide. DGGS aims to compile the Alaska Quaternary fault and fold database in conformance with these international standards and ultimately provide a comprehensive resource for seismic hazard assessment and regional policy planning.

Figure 1. Shaded relief map of the State of Alaska showing Quaternary active faults taken from the Neotectonic Map of Alaska (Plafker and others, 1994). There are more active faults in Alaska than are shown on the map. These faults will be added as DGGS evaluates the published literature.
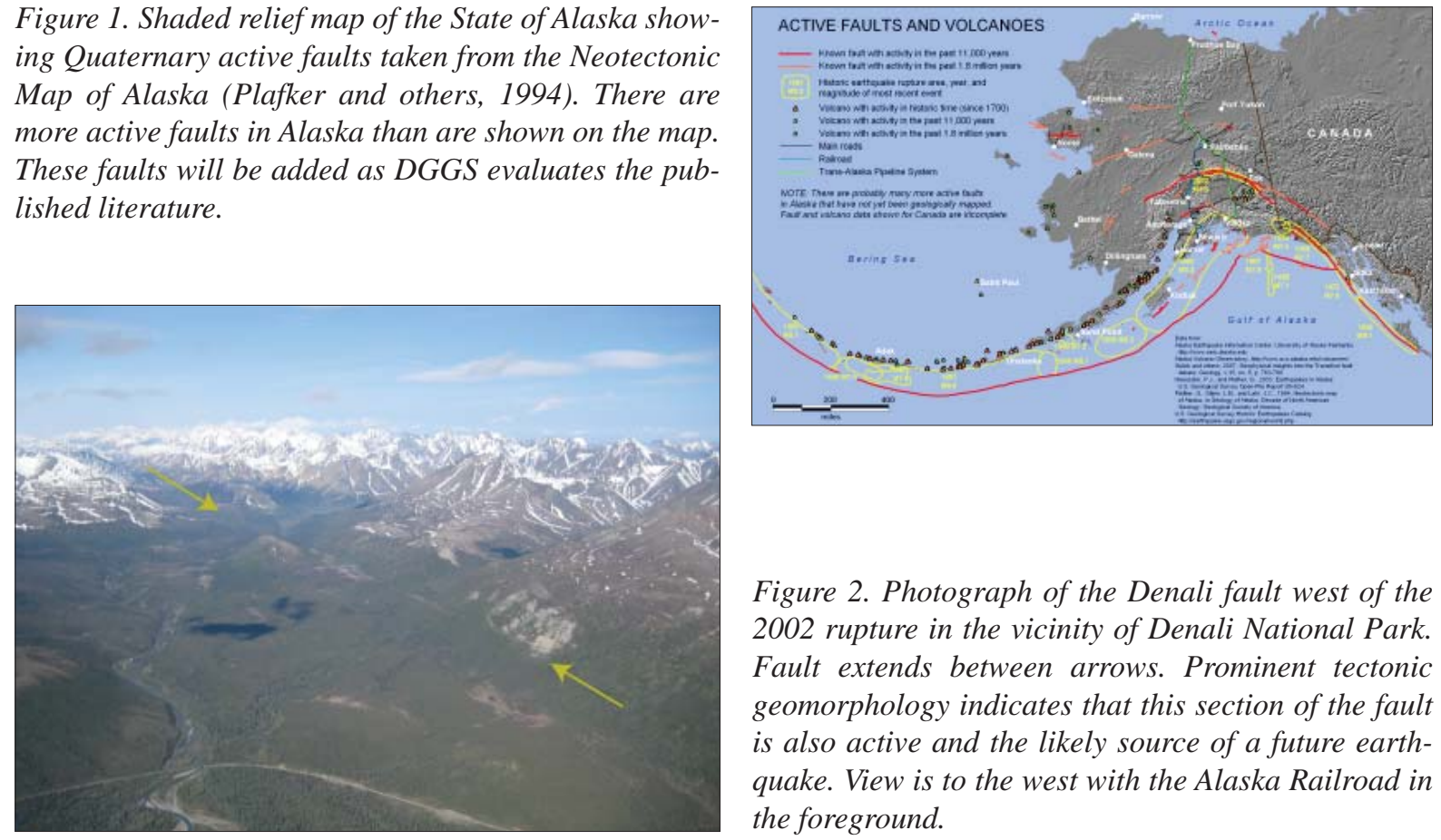

Figure 2. Photograph of the Denali fault west of the 2002 rupture in the vicinity of Denali National Park. Fault extends between arrows. Prominent tectonic geomorphology indicates that this section of the fault is also active and the likely source of a future earthquake. View is to the west with the Alaska Railroad in the foreground. 


\section{SURFICIAL GEOLOGIC MAPPING OF THE TYONEK AREA, WEST COOK INLET, ALASKA}

In conjunction with the 2009 Tyonek STATEMAP project (described separately), the Division of Geological \& Geophysical Surveys (DGGS) is undertaking surficial geologic mapping on the west side of Cook Inlet (fig. 1). The map area straddles the northwest margin of Cook Inlet basin, includes extensive exposures of Tertiary-age nonmarine rocks, and encompasses nearly 800 square miles of State and Native corporation land.

Glacial, volcanic, and mass movement deposits dominate the Tyonek landscape (fig. 2). During the last major glaciation, the map area was invaded by the massive Cordilleran Ice Sheet, which spread eastward into the Cook Inlet trough from sources in the southern Alaska Range to the west. Following the maximum ice extent about 23,000 years ago, the glacier complex thinned and ice from individual lobes fluctuated as it deposited glacial and glacioestuarine material that is now preserved in the coastal lowland area of northwestern Cook Inlet. Volcanism centered on the Mt. Spurr complex temporarily dammed the valley of Chakachatna River, producing massive flooding in the southwestern part of the map

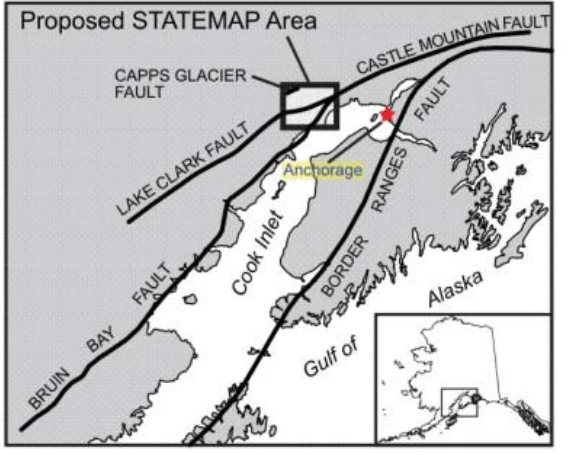

Figure 1. Location map of Tyonek area. area. This flooding deposited a broad expansion fan with an apex where the Chakachatna River emerges from its narrow bedrock valley. Channels and terraces formed by massive outburst floods from glacier damming are recognized in several locations. Massive landslides displace bedrock and Quaternary sediments in the uplands and valley walls of the study area. Some landslides are clearly delineated by their steep, linear to arcuate scarps and headwalls, wrinkle ridges, sag ponds, rotated blocks, and terminal bulges. Less obvious is the north-moving drift blanket south of Chichantna River, recognizable by a concentration of short, subparallel ground cracks and an associated terminal bulge. The volcanic plateau in the northwestern map area is being dismantled by complex landslides along the eastern and western margins. An incipient trellis drainage system, developed along generally north-striking linear ground fissures on the plateau, is evidence of gravitational spreading to the east and west. The cause of this spreading is unknown.

New geologic mapping will lead to a better understanding of the region's geologic framework and provide geologicresource and -hazards data critical to land-use decisions. This project's products will be a report and geologic map at 1:63,360 scale. Geologic maps of the Tyonek area will be completed by late 2011. Bedrock and neotectonic mapping performed in conjunction with this project is described separately.

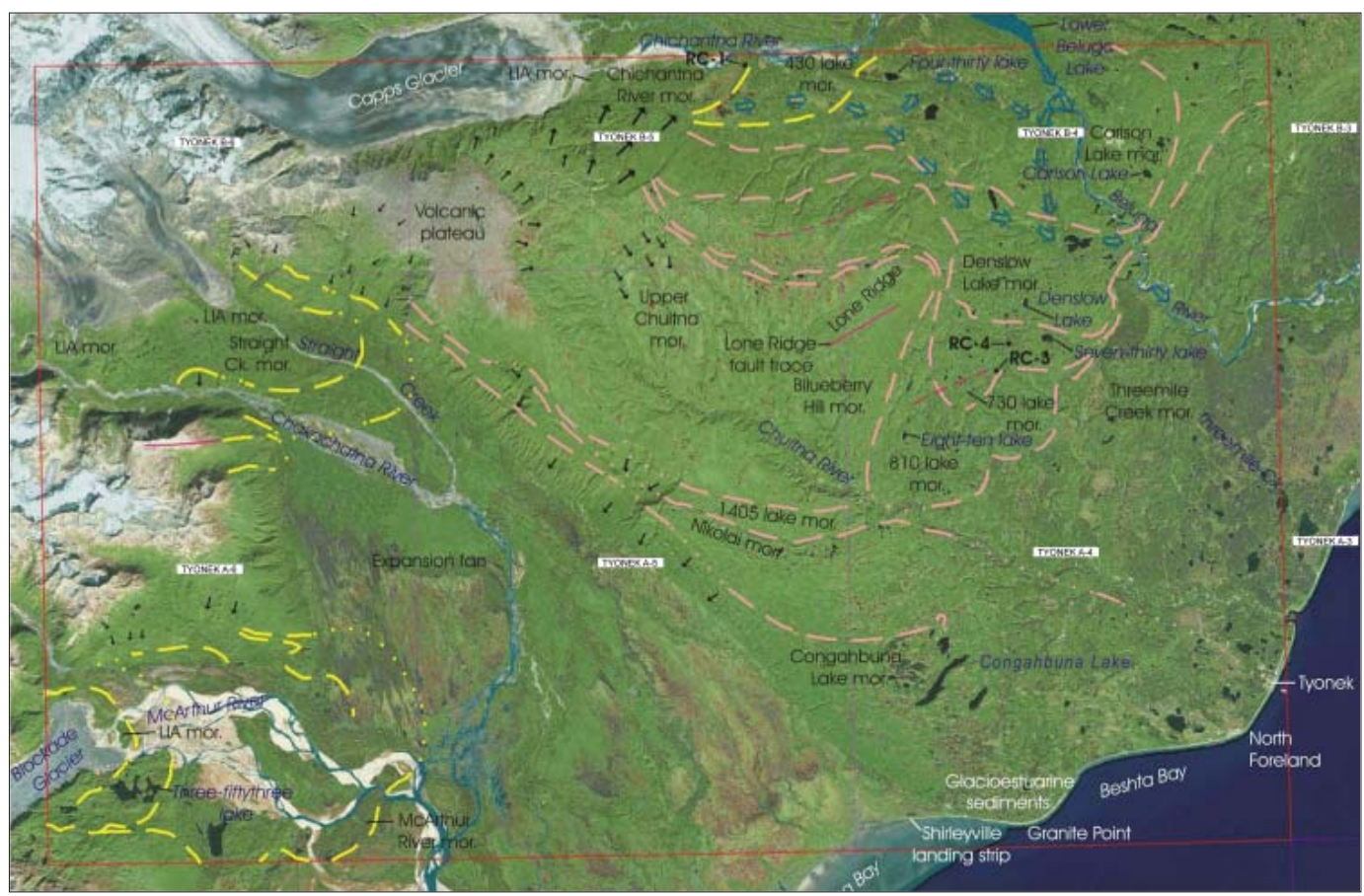

Figure 2. Prominent surficial features in Tyonek area. 


\section{SURFICIAL GEOLOGIC MAPPING OF THE SLATE CREEK AREA, MT. HAYES QUADRANGLE, SOUTH-CENTRAL ALASKA}

The Alaska Division of Geological \& Geophysical Surveys (DGGS) released airborne magnetic and electromagnetic geophysical maps for 442 square miles of the northern Chistochina mining district in early 2009. DGGS conducted geologic mapping of about 113 square miles of the geophysical survey tract during July 2009. This mapping project is funded primarily by State CIP funds, with supplementary federal STATEMAP funding. The northwestern Mentasta-Slana mapping project is part of DGGS's Airborne Geophysical/Geological Mineral Inventory program, an annual investment by the State of Alaska to expand Alaska's geologic and mineral resources knowledge base, catalyze future private-sector mineral exploration and development, and guide state planning.

The Slate Creek study area is located in the southern foothills of the Alaska Range about 140 miles southeast of Fairbanks and 20 miles east of Paxson (fig. 1). Approximately 183,356 ounces of placer gold have been mined from the region since 1898, with most production from the historic Slate Creek subdistrict. During the Pleistocene, extensive alpine glaciers and ice caps in the Alaska Range coalesced with the Cordilleran Ice Sheet and reached all the way to the Gulf of Alaska in some places. The map area was also extensively glaciated during late Wisconsin time, with ice reaching up to $50 \mathrm{~km}$ from the rangefront of the Alaska Range at its maximum extent $c a$. 25,000-20,000 years ago. Glacial deposits dominate the landscape but thick deposits are relatively uncommon, probably due to a predominance of scouring by the massive ice streams that inundated the map area. Glacially oversteepened slopes and comparatively recent loss of ice buttresses, possibly combined with proximity to the Denali fault and its attendant seismicity, have resulted in numerous landslides throughout the study area. Landslides vary widely in age and size, and several have had profound effects on local landscape evolution by damming lakes and diverting drainages (fig. 2).

New geologic mapping will lead to a better understanding of the region's geologic framework and provide geologic-resource and hazards data critical to land-use decisions. Products of this project will be a report and geologic map at 1:50,000 scale. Geologic maps of the Slate Creek-Slana River area will be completed by late 2010. Bedrock mapping and paleoseismic studies performed in conjunction with this project are described separately..

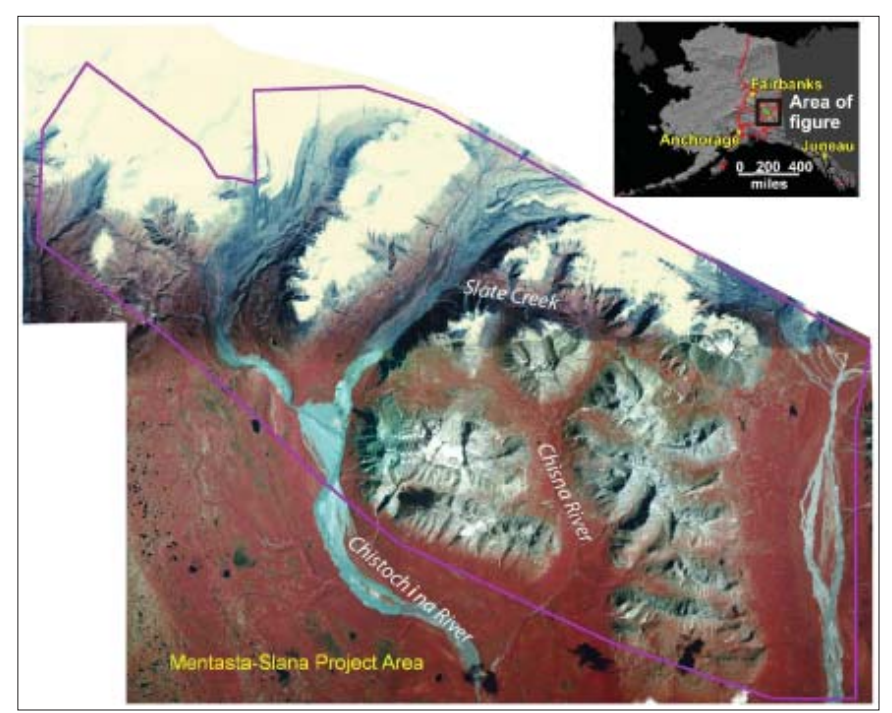

Figure 1. Location map of Slate Creek area.

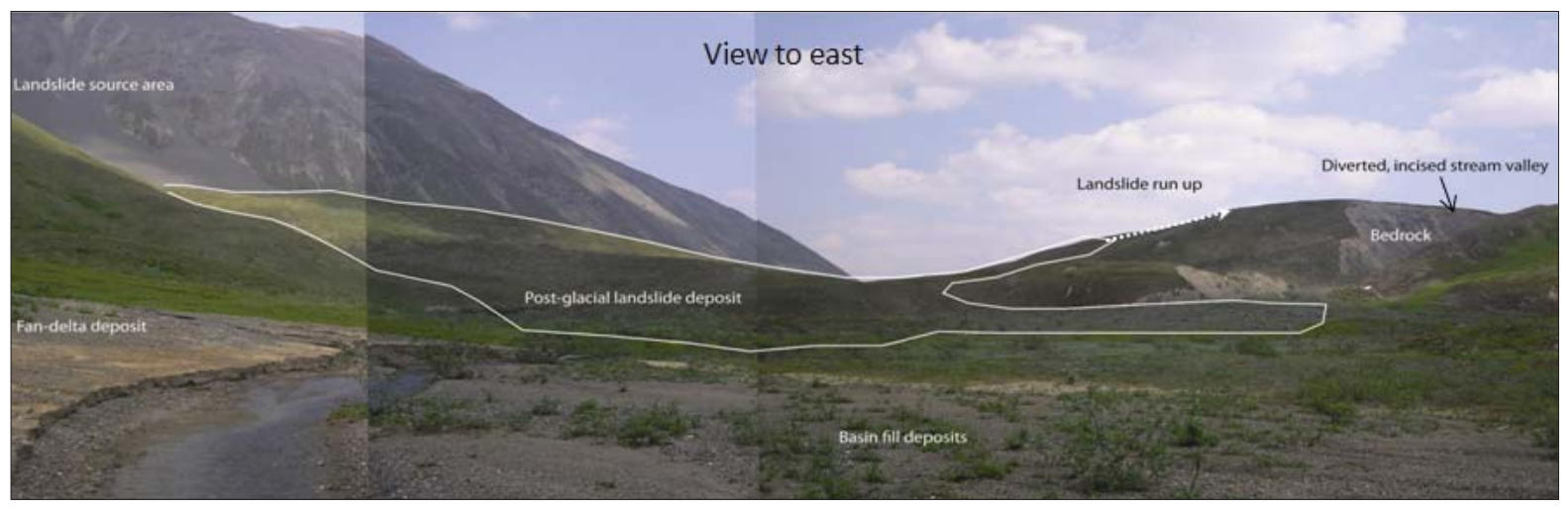

Figure 2. Photomosaic of postglacial landslide deposits in upper Chisna River valley. The landslide crossed the valley and ran up the opposite wall, thus damming a lake, diverting drainages, and leading to extensive basin infilling and fan-delta deposition in the upper valley prior to draining of the lake. 


\section{SURFICIAL GEOLOGY OF PART OF THE SAGAVANIRKTOK QUADRANGLE, NORTH SLOPE, ALASKA}

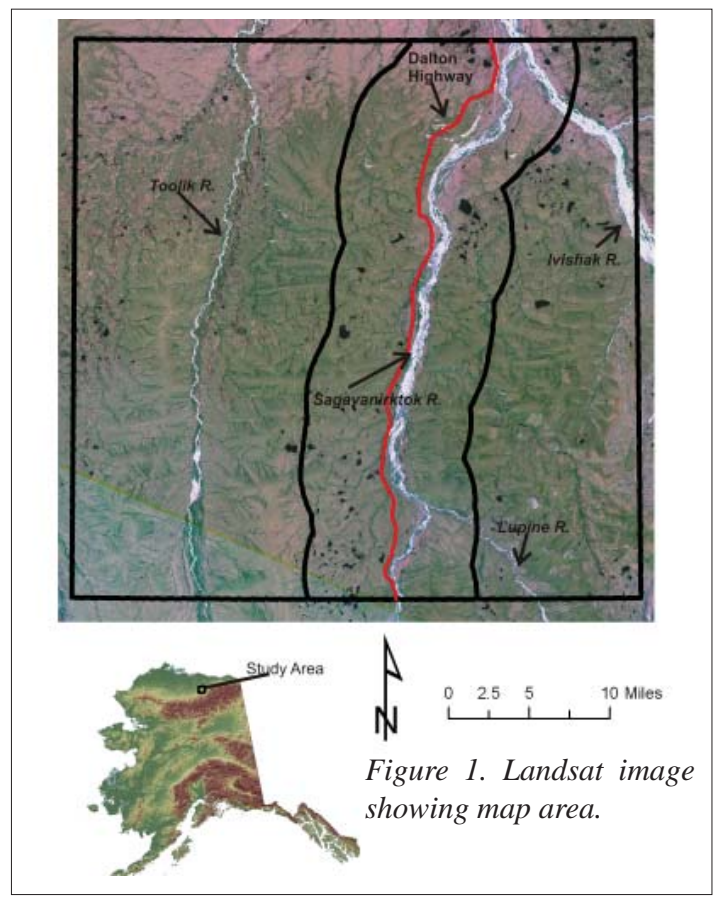

In 2009 the Alaska Division of Geological \& Geophysical Surveys (DGGS) continued work begun in 2008 to map at a scale of 1:50,000 the surficial geology of a 1,212-square-mile area straddling the Dalton Highway in the northern Brooks Range foothills in the Sagavanirktok B-3, B-4, B-5, A-3, A-4, and A-5 quadrangles (fig. 1). The Dalton Highway, which parallels the Trans-Alaska Pipeline System (TAPS), is the only ground transportation route connecting Prudhoe Bay to Fairbanks and points farther south. Identifying geologic materials and processes in this corridor is important so the road and TAPS can be maintained and potential impacts from geologic hazards, such as melting permafrost, slope failure, and flooding, can be assessed. Additionally, geologic mapping will provide information for future planning, resource exploration, and development, including a proposed natural-gas pipeline. With increasing concerns about environmental impacts resulting from climate change, baseline geologic data are needed, especially in arctic regions where information is limited. Such information will help us to assess the rate and severity of landscape change.

In the map area, ice advanced northward from the Brooks Range during late Tertiary and Pleistocene glaciations, occupying major valleys containing the modern Sagavanirktok, Toolik, Ivishak, and Lupine rivers and some smaller tributary valleys. Mapping

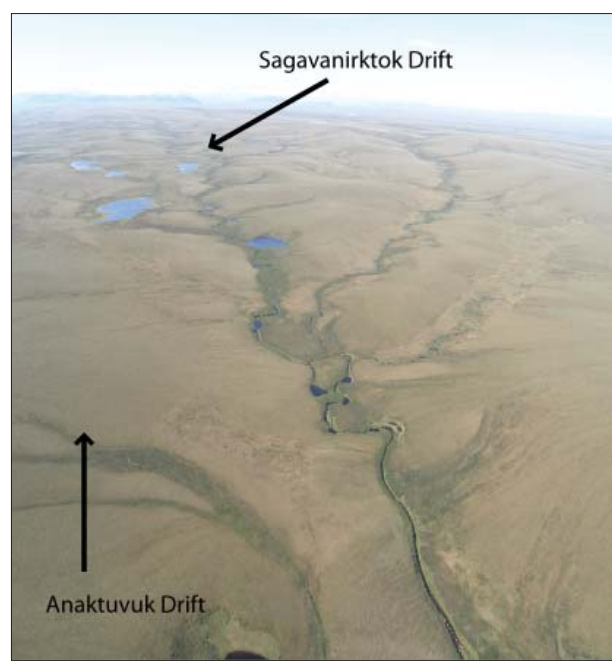

Figure 2. Oblique photo of Sagavanirktok River and Anaktuvuk River drifts. Although Sagavanirktok River drift retains some primary glacial morphology, Anaktuvuk River drift is characterized by broad, gently sloping surfaces extensively modified by colluvial and periglacial processes. View is to the southeast.

map of 377 square miles in the central study area along the TAPS route will be completed in 2010. In the spring of 2009, preliminary surficial geologic interpretations were part of a combined bedrock- and surficial-geologic map presented at the Alaska Geological Society Conference and a map submitted to the U.S. Geological Survey in fulfillment of STATEMAP contract requirements. mask primary glacial features of the older deposits. Thermokarst lakes and other features associated with extensive permafrost are the main characteristics of the landscape.

We anticipate that a reconnaissance map of the entire area and a more detailed has identified deposits from the Itkillik (late Pleistocene), Sagavanirktok River (middle Pleistocene), and Anaktuvuk River (early Pleistocene) glacial advances. Deposits from the Anaktuvuk River advance have been modified extensively by colluvial and periglacial processes and are characterized by broad, gently sloping surfaces (fig. 2). The younger Itkillik and Sagavanirktok River deposits, although somewhat modified by slope processes (fig. 3), retain more primary glacial morphology and tend to have steeper slopes (fig. 2) and more boulders protruding at the surface.

Toolik River valley lacks younger glacial deposits of Itkillik and Sagavanirktok River ages, possibly because the valley was beheaded by stream erosion during or shortly after the Anaktuvuk River glacial advance. This would have limited the extent of ice advances during those later glaciations because of reduced source area. In the Toolik River valley and beyond the limits of Itkillik and Sagavanirktok River deposits in the eastern part of the map area, colluvial and periglacial processes are dominant and

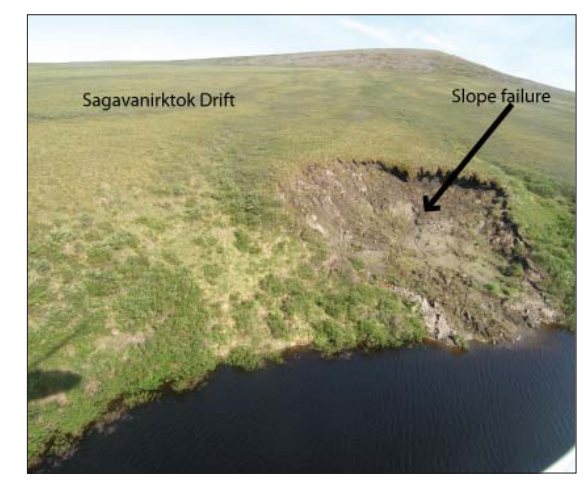

Figure 3. Oblique photo of slope failure in Sagavanirktok River drift. View is to the south. 


\section{TSUNAMI INUNDATION MAPPING FOR ALASKA COASTAL COMMUNITIES}

With funding from Congress, the National Oceanic \& Atmospheric Administration (NOAA) initiated the National Tsunami Hazard Mitigation Program in 1997 to assist Pacific states in reducing losses and casualties from tsunamis. The program included funding for five states (Alaska, Hawaii, Washington, Oregon, and California) to address four primary issues of concern: (1) quickly confirm potentially destructive tsunamis and reduce false alarms, (2) address local tsunami mitigation and the needs of coastal residents, (3) improve coordination and exchange of information to better utilize existing resources, and (4) sustain support at state and local level for long-term tsunami hazard mitigation. In 2005, following the catastrophic Sumatra earthquake and tsunami, the U.S. program was expanded to include Atlantic and Gulf of Mexico states and territories.

As part of this program, DGGS participates in a cooperative project with the Alaska Division of Homeland Security \& Emergency Management (DHSEM) and the University of Alaska Geophysical Institute (UAGI) to prepare tsunami inundation maps of selected coastal communities. Communities are selected on the basis of tsunami risk, infrastructure, availability of bathymetric and topographic data, and willingness of a community to use results for emergency preparedness. For each community, DGGS and UAGI develop multiple hypothetical tsunami scenarios that are based on the parameters of potential underwater earthquakes and landslides. We have completed and published tsunami inundation maps for the Kodiak area, Homer, and Seldovia. A draft report and maps for Seward are currently under review for publication in early 2010 (see figure). Data compilation and inundation modeling for the next two communities, Whittier and Sitka, are underway.

To develop inundation maps, we use complex numerical modeling of tsunami waves as they move across the ocean and interact with the seafloor and shoreline configuration in shallower nearshore water. UAGI conducts the wave modeling using facilities at the Arctic Region Supercomputing Center. DGGS, UAGI, and DHSEM meet with community leaders to communicate progress and results of the project, discuss format of resulting maps, and obtain community input regarding past tsunami effects and extent. DGGS publishes the final maps along with explanatory text, which are available in both hardcopy and digital formats. DGGS also makes the GIS files of inundationlimit lines available to the local communities for use in preparing their own tsunami evacuation maps.

We have presented results of this project at international tsunami symposia in Istanbul, Turkey, Seattle, Washington, and Hania, Greece; at the Tsunami Society symposium in Honolulu, Hawaii; at the International Union of Geodesy and Geophysics Symposium in Perugia, Italy; and at the American Geophysical Union annual meetings in 2003 through 2007. In addition, this project has been the subject of articles in Geotimes and TsuInfo Alert Newsletter.

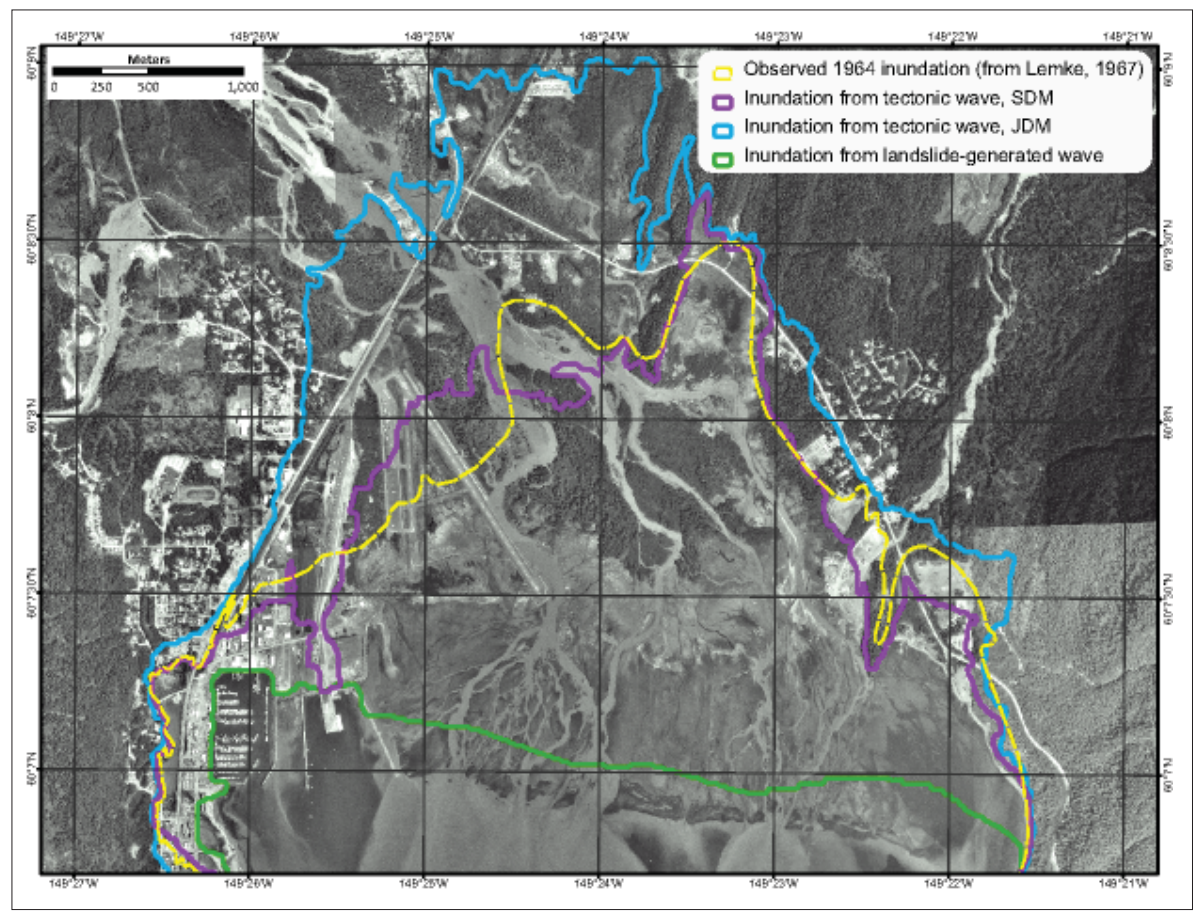

Tsunami inundation map for Seward, Alaska. 


\section{REDOUBT VOLCANO: 2009 ERUPTION RESPONSE AND GEOLOGIC INVESTIGATIONS}

In 2008 the Alaska Volcano Observatory, led by DGGS, initiated efforts to produce an updated geologic history and hazard assessment of Redoubt Volcano, on the west side of Cook Inlet about $160 \mathrm{~km}$ (100 miles) southwest of Anchorage. In the autumn of 2008, after initial mapping efforts, increased thermal and seismic activity led to a heightened state of vigilance by AVO. On March 15, 2009, Redoubt Volcano erupted for the first time since 1990, producing more than 19 explosions between March 22 and April 4. The explosions produced ash plumes to 18,300 meters elevation and tephra fall up to 1.3 centimeters thick onto surrounding communities. Following the final explosion on April 4, a third lava dome began to grow. The dome reached 71 million cubic meters in volume after about nine weeks, and remains that size today. During the explosive phase of the eruption, at least three major lahars traveled almost $48.3 \mathrm{~km}$ to the coast, inundating the Drift River Oil Terminal with ice and mud, causing oil production in Cook Inlet to be shut down temporarily, and the terminal to be evacuated of personnel. Domestic and international flights were diverted and schedules disrupted by the eruption; this included a closure of Anchorage's international airport for about 12 hours. The Alaska Volcano Observatory (a cooperative program of the U.S. Geological Survey, University of Alaska Fairbanks Geophysical Institute, and DGGS) monitored the eruption and provided a stream of essential information to emergency management agencies, private-sector entities, and the public.

Activities and Results: DGGS-AVO geologists were involved in all aspects of the eruption response, including operations-room monitoring, hazard mitigation operations, website maintenance, public outreach, and geologic observations and fieldwork. Geologic work comprised gas collection and observation overflights; tephra-fall sampling and mapping; flowage deposit sampling and mapping; and field and helicopter logistics coordination. Flowage studies included analysis of seismic activity and camera images for lahars and pyroclastic flows. Major lahar events occurred on March 23 and 26, and April 4. The March events consisted of up to 80 percent ice, and the April 4 event was likely a hyperconcentrated flow, producing water-rich flooding that locally breached the Drift River banks tens of meters and spread far across the river's delta. We are digitizing lahar deposit extents in GIS from satellite images; area and volume calculations will be correlated with USGS geologists' study results. Few pyroclastic flows were produced during the 2009 eruption, and were limited to the Drift glacier gorge or as far as the piedmont lobe of the Drift glacier. Monitoring of growth of the dome has been in collaboration with AVO- and CVO-USGS geologists. From combining photogrammetry analysis, Forward Looking Infrared (FLIR)-thermal imaging, and time-lapse image analysis, we have been able to calculate volumes, effusion rates and morphologic changes during dome growth. These results have helped us to correlate dome growth with seismicity, gas output, rockfall, and other eruption indicators.

Products: AVO-DGGS geologists moderated an oral and poster session on the 2009 eruption of Redoubt Volcano at the annual American Geophysical Union conference in San Francisco in December 2009. A geologic map of the 2009 eruptive products of Redoubt Volcano will be published through DGGS, possibly as part of the Integrated Cook Inlet Volcanoes Hazard Assessment Report. Additional data will be made available as DGGS Raw Data Files. A paper on dome growth and morphologic changes written in conjunction with AVO- and CVO-USGS geologists will be submitted for publication in 2010 .

Figure 1. View southwest showing Redoubt Volcano (back skyline, with plume), the Drift River exiting the mountain range (center right), and Drift River Oil Terminal (lower right). The photograph was taken just after the April 4, 2009, lahar flooded the entire upper Drift River and large portions of its alluvial fan. Note the contrast between the dark, lahar-swept fan in the foreground and the unflooded snow-covered floodplain beyond, and the lahar deposits extending across the beach into Cook Inlet (lower left). (Photo by Game McGimsey, AVO/USGS.)

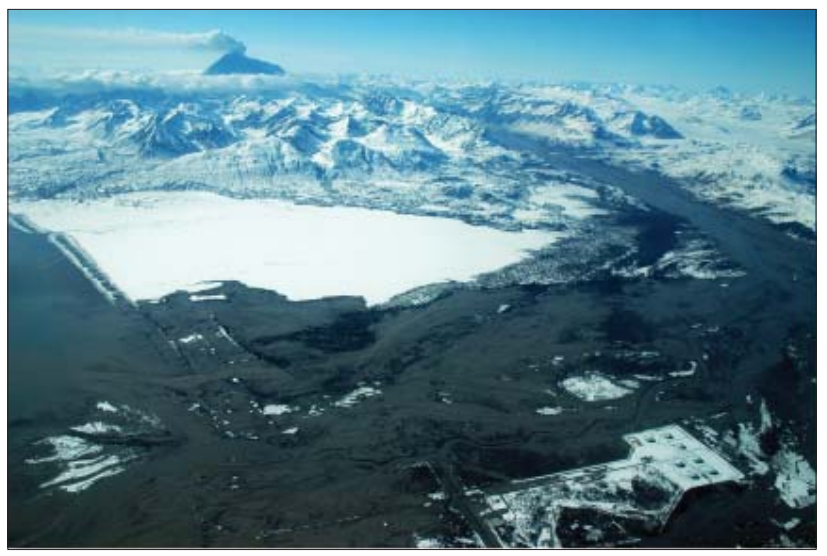




\section{CHIGINAGAK VOLCANO: MONITORING THE PERSISTENT ENVIRONMENTAL DAMAGE FROM THE 2005 ACID CRATER LAKE DRAINAGE}

Mount Chiginagak is a hydrothermally active volcano on the Alaska Peninsula, approximately 170 kilometers (100 miles) south-southwest of King Salmon. Sometime between November 2004 and May 2005, a 400-meter-wide ( 1,300-foot-wide), 100-meter-deep ( 330-foot-deep) lake developed in the formerly snow- and-ice-filled crater of the volcano. In early May 2005, an estimated 3 million cubic meters (106 million cubic feet) of sulfurous, clayrich debris and acidic water exited the crater through tunnels in the base of a glacier that breaches the south crater rim. More than 27 kilometers (17 miles) downstream, the acidic waters of the flood reached approximately 1.3 meters (4 feet) above current water levels and inundated an important salmon spawning drainage, acidifying Mother Goose Lake from surface to depth ( $\mathrm{pH}$ of 2.90 to 3.06) and preventing the annual salmon run in the King Salmon River. A release of caustic gas and acidic aerosols from the crater accompanied the mud flow and flood, causing widespread vegetation damage along the flow path. A DGGS-led interdisciplinary science team has been monitoring the status of the remaining crater-lake water that continues to flow into Mother Goose Lake. Despite the thin ice layer that was observed on the crater lake in August 2009 (fig. 1), more than 1 million cubic meters (35 million cubic feet) of water remains

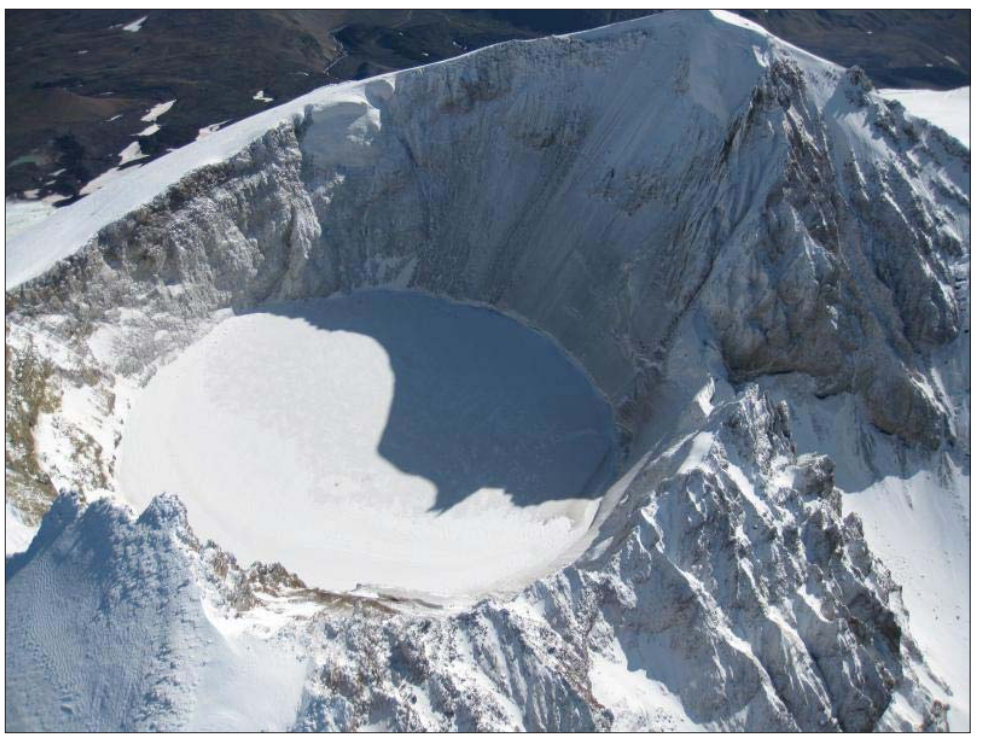

Figure 1. A thin layer of ice covers the summit crater lake at Chiginagak Volcano on August 28, 2009. Photo by Janet Schaefer. in the crater and continues to supply acidic water to Mother Goose Lake and the King Salmon River. August 2009 pH measurements indicate a slight improvement in habitat conditions; however, the water is far from hospitable. Anomalous high concentrations of iron $(\sim 25 \mathrm{mg} / \mathrm{L})$ and aluminum $(\sim 18 \mathrm{mg} / \mathrm{L})$ appear to be the most serious environmental threat in terms of metals. Hazardous metals such as arsenic, chromium, and copper are elevated well above normal levels. Based on the large volume of acidic water remaining in the crater lake, the likely continued contribution of acid water from the volcano's hydrothermal system, and the prolonged hydrolysis of

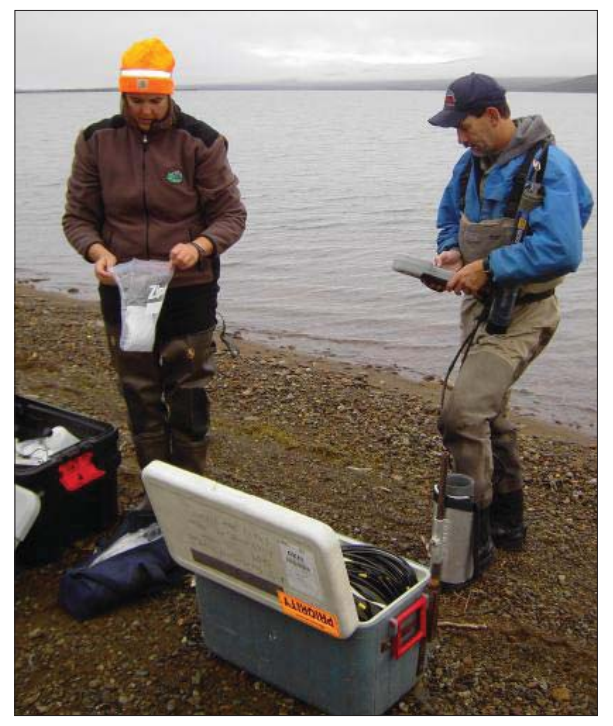
iron and aluminum in the stream draining the crater and in Mother Goose Lake, improved water quality is not expected for at least several more years.

\section{Geologic Mapping and Volcano Hazard Assessment}

The DGGS-led geologic mapping and hazard assessment fieldwork that began in 2004 was completed in 2008. This work has been supported by the U.S. Fish \& Wildlife Service (USFWS). Investigations have revealed a long history of hydrothermal activity, debris avalanches, and lava flows at the volcano. A geologic map and volcano hazard assessment are scheduled to be published by DGGS in 2010.

Figure 2. Janet Schaefer (AVO/DGGS) and Doug McBride (USFWS) calibrate instruments on the shore of Mother Goose Lake. In 2009, the $\mathrm{pH}$ of Mother Goose Lake was 4.9, up from 2.9 measured in September 2005, 41/2 months after the acid flood event from Chiginagak volcano. Photo by Ron Britton, USFWS, August 25, 2009. 


\section{GEOMORPHOLOGY AND HYDROGEOLOGY OF THE 2008 PHREATOMAGMATIC ERUPTION OF OKMOK VOLCANO}

On July 12, 2008, with less than 5 hours of precursory seismic activity, Okmok volcano, in the central Aleutians, erupted explosively, marking the beginning of a 5-week-long eruption that dramatically changed the morphology and groundwater system within the 8-km-wide caldera. The initial explosion sent an ash- and gas-rich column to $15 \mathrm{~km}$ above sea level. Early in the eruption, heavy rain mixed with new tephra on the flanks of the volcano, generating lahars that traveled across the upper slopes of the volcano and down all major drainages, creating large new deltas along the shoreline. For the next 5 weeks, eruption intensity waxed and waned with explosions occurring from multiple vents on the caldera floor as rising magma interacted with shallow groundwater. One crater formed next to, and eventually captured and drained, the largest pre-existing caldera lake (total volume drained was 13.6 million cubic meters). As the eruption subsided, coalescing maar and collapse craters eventually filled with water, forming a new lake to the west of cone $\mathrm{D}$ (fig. 1a) and dramatically changing the morphology and volume of the old lake (fig. 1b). The longest-lived vent formed a 250-300-m-high, 1.5-kmwide tuff cone on the western flank of pre-existing cone $\mathrm{D}$. This new tuff cone, the new lakes and collapse pits, and the accumulation of many tens of meters of fine-grained tephra have significantly altered the Okmok landscape. This eruption was sub-

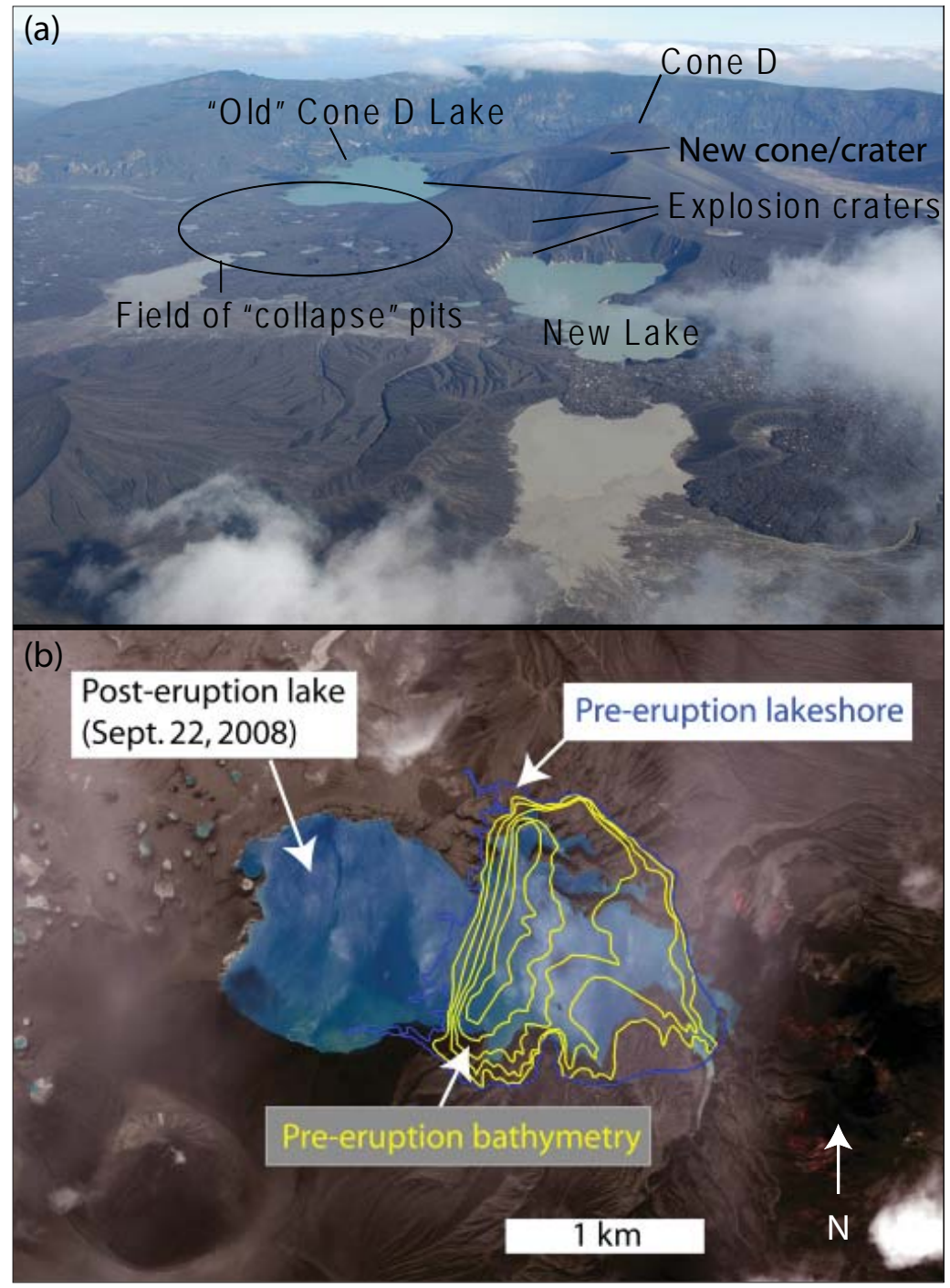

Figure 1. (a) Oblique aerial view, looking east, of Okmok caldera showing the new tuff cone, explosion craters, lakes, and a field of collapse pits adjacent to Cone D. (b) Post-eruption satellite image annotated to show the pre-eruption lakeshore (in blue) of "old" Cone D lake, the pre-eruption bathymetry (in yellow), and the expanded post-eruption lake, north of cone $D$.

stantially larger than any eruption since that of 1817 (which destroyed the then unoccupied village of Egorkovskoe on the north coast of Umnak) and far larger than the eruptions of 1945, 1958, or 1997.

DGGS Geologist Janet Schaefer is a member of an interdisciplinary team of Alaska Volcano Observatory (AVO) scientists scheduled to visit Okmok in the summer of 2010 to investigate and document this fascinating eruption, the first phreatomagmatic event to occur in the United States since the 1977 eruption of Ukinrek Maars. Fieldwork anticipated for summer 2009 was postponed as staff and funding were redirected toward eruption response at Redoubt volcano. In 2010, work will focus on the stratigraphy and sedimentology of the tephra deposits from the 2008 eruption, documentation and description of vent evolution, and the creation of a post-eruptive geologic map. 


\section{KASATOCHI INTEGRATED STUDY: RESPONSE OF A DEVASTATED ECOSYSTEM}

The August 7-8, 2008, eruption of Kasatochi volcano, located near Adak in the Aleutian Islands, was short, powerful, and came with little warning. Over the course of about 24 hours a series of explosive eruptions produced pyroclastic flows that swept all sides of the tiny island, building new beaches some 400 meters seaward and leaving deposits more than 10 meters thick. Additionally, the explosions enlarged the 1,100-meter-diameter summit crater by more than 250 meters. Ash clouds reached the stratosphere and were carried rapidly to the east, disrupting air traffic to and from Alaska and along the North Pacific air route. The clouds ultimately circled the earth, producing vibrant sunsets in some 'Lower 48' states. The eruption was preceded by a short (36-hour) yet exceptionally intense earthquake swarm, with more than a thousand earthquakes greater than 2 in magnitude (M), the largest of which was M 5.7 (by comparison, at Redoubt volcano there were only nine earthquakes with magnitude 2 or greater spanning the six-month-long 2009 eruption). Kasatochi had not erupted for at least a century, and perhaps not during the 250 years of recorded history in Alaska.

Despite its small size-some 2.5 kilometers in diameter-Kasatochi Island supported a lush ecosystem, and that ecosystem was devastated by the eruption. Bird nesting habitat was destroyed. Most plants were thickly covered, and many more were ripped up by erosive pyroclastic flows. The extent of charring of plants and insects by the hot pyroclastic flows was unknown. Fringing kelp forests, upon which the nearshore ecosystem depends, were destroyed by pyroclastic flows and falls that covered their holdfasts and abraded their stems.

Kasatochi Island was one of about seven major nesting colonies for least and crested auklets, among other seabirds. Hundreds of thousands of auklets return to their individual nesting cavities in talus piles each summer to lay and hatch eggs and to fledge their young. The auklets returned in 2009 to find all their nesting cavities thickly covered by pyroclastic deposits. Unlike puffins, auklets do not dig burrows. The loss of their traditional cavities left them with no place to nest, and eggs were dropped at random, many in the ocean. Among hundreds of thousands of returning birds there was not a single successfully fledged chick.

Kasatochi Island presents a rare opportunity to watch an ecosystem recover and rebuild. In recognition of that, the North Pacific Research Board, the U.S. Geological Survey, and the U.S. Fish \& Wildlife Service have funded an integrated study spanning the shallow marine ecosystem, birds, insects, plants, and soil development. The Alaska Volcano Observatory (AVO) will monitor the stability of the new, unstable slopes (seacliff retreat at rates of tens of meters per month was documented in summer 2009), map the new deposits, and produce the first geologic map of the entire island. DGGS leads the effort to produce the geologic map, aiming for release by the end of 2010 , and will work with USGS and UAF colleagues in AVO to characterize and study the magma that produced this remarkably violent, yet short, eruption.

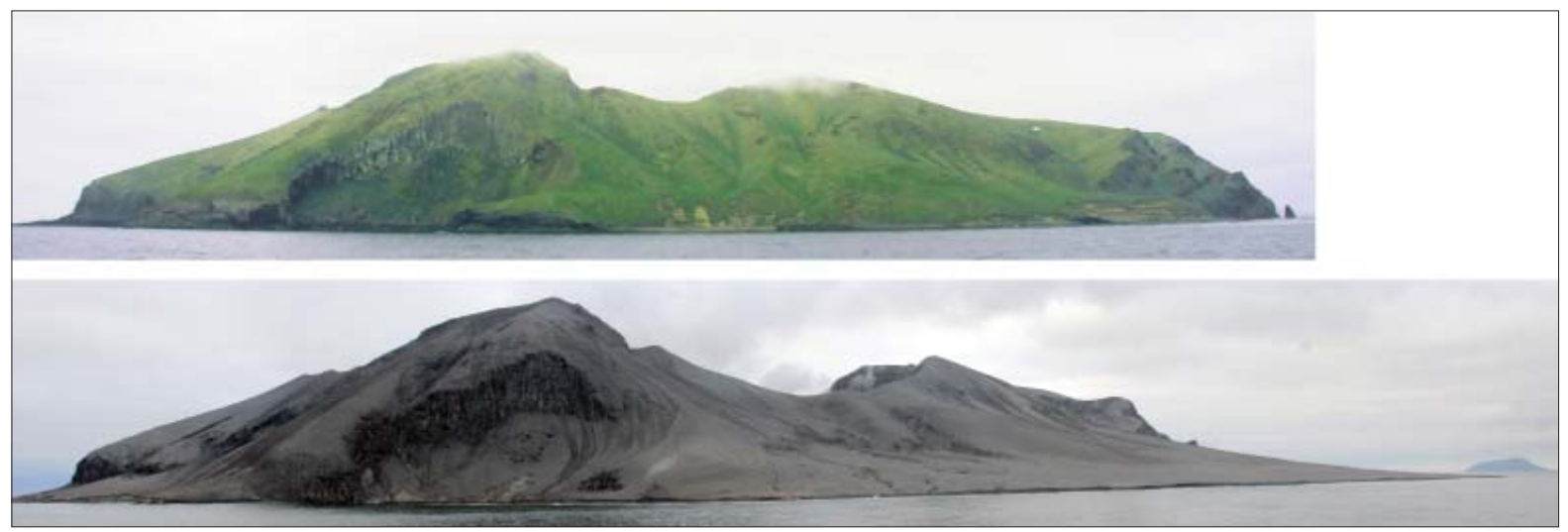

Photographs of Kasatochi Island from the west at approximately the same angle. Both are full-color, mid-summer photographs. The top photograph was taken June 11, 2008, about two months before the eruption and shows the lush, though treeless, ground cover of flowers and other plants typical of the Aleutians. The bottom photograph was taken August 23, 2008, about two weeks after the eruption. All plants have been eroded away or covered. Pyroclastic flows have built fans that cover previous beach bluffs and extend the shoreline up to 400 meters (most noticeable on right [south]) side. Portions of the crater rim are substantially lower, allowing previously impossible views of the inside crater wall. Photographs courtesy of U.S. Fish \& Wildlife Service. 


\section{ALASKA VOLCANO OBSERVATORY WEBSITE AND DATABASE}

The Alaska Volcano Observatory (AVO) public website (http://www.avo.alaska.edu) serves about 1,500,000 pages and approximately 300 gigabytes of data to well over 100,000 unique visitors per month, and is among the top ten USGS and USGS-affiliated web sites in the country. It continues to be the most complete single resource addressing Quaternary volcanism in Alaska. DGGS was the original creator of the AVO website in 1994, and continues to be the site designer, builder, and manager.

During 2009, the eruption of Redoubt volcano brought about a flurry of development on the AVO website and supporting servers, using new technologies to ensure the stability of the website during unprecedented high traffic volumes, as well as reaching new audiences with information. Responding to public requests, DGGS created the "Alaska_avo" twitter page, viewable at http://twitter.com/alaska_avo. Short, informal notifications are sent to the page, which has more than 8,000 followers.

The large traffic spike to the AVO website during the Redoubt eruption (averaging a million page views per day over the entire month) necessitated additions and enhancements to help keep the website available and stable. A squid caching server was added to the primary webserver, helping to ease the load on the database. Software was written to copy and synchronize the images from the AVO webcams, webicorders, and image database to the USGS content delivery network (CDN, located outside Alaska). By hosting these high-bandwidth items on the CDN, AVO was able to continually deliver new content to the public via the website. Finally, in the event that all of the above modifications failed to support the website, DGGS created a low-bandwidth version of the website that only contained the latest eruption information in text format, as well as a few links to relevant emergency information.

AVO's website content is dynamically queried from a MySQL database named GeoDIVA (Geologic Database of Information on Volcanoes in Alaska). GeoDIVA maintains complete, flexible, timely, and accurate geologic and geographic information on Pleistocene and younger Alaska volcanoes to assist scientific investigations, crisis response, and public information. GeoDIVA is currently the most comprehensive, current, and authoritative source for information about Alaska volcanoes. GeoDIVA employs a modular structure, allowing for continuing development of new content areas. After modules are completed, they undergo scheduled maintenance so that they remain timely and useful. Current modules include: bibliography (4,300+ references); basic volcano information ( 140 major and 200 minor volcanic features, 52 "historically active" volcanoes); eruption history information (information, text, and references for more than 430 historical eruptions); images $(17,000+)$; sample information $(\sim 4,400)$; hand sample storage $(15,000+)$; and vent count ( 1,200 vents). Modules in development and initial data-loading stages include geochemistry ( 1,500 analyses, 60,000 records); petrology ( 70 samples of 1,000-point point-count analyses); GIS data, geochronology, and tephra chronology.

AVO is on the leading edge of web and database development for volcano observatories, and is actively sharing its expertise with other observatories in the U.S. DGGS is following new and emerging technologies that will allow us to further enhance AVO's web presence and data dissemination abilities. DGGS continually refines and enhances the applications that AVO and other observatories use on a regular basis. We will focus on continual incremental improvements to the site, and serving new database modules as they become available.

The "Alaska_avo" twitter feed has more than 8,000 followers who receive short, informal updates about current Alaska volcano activity.

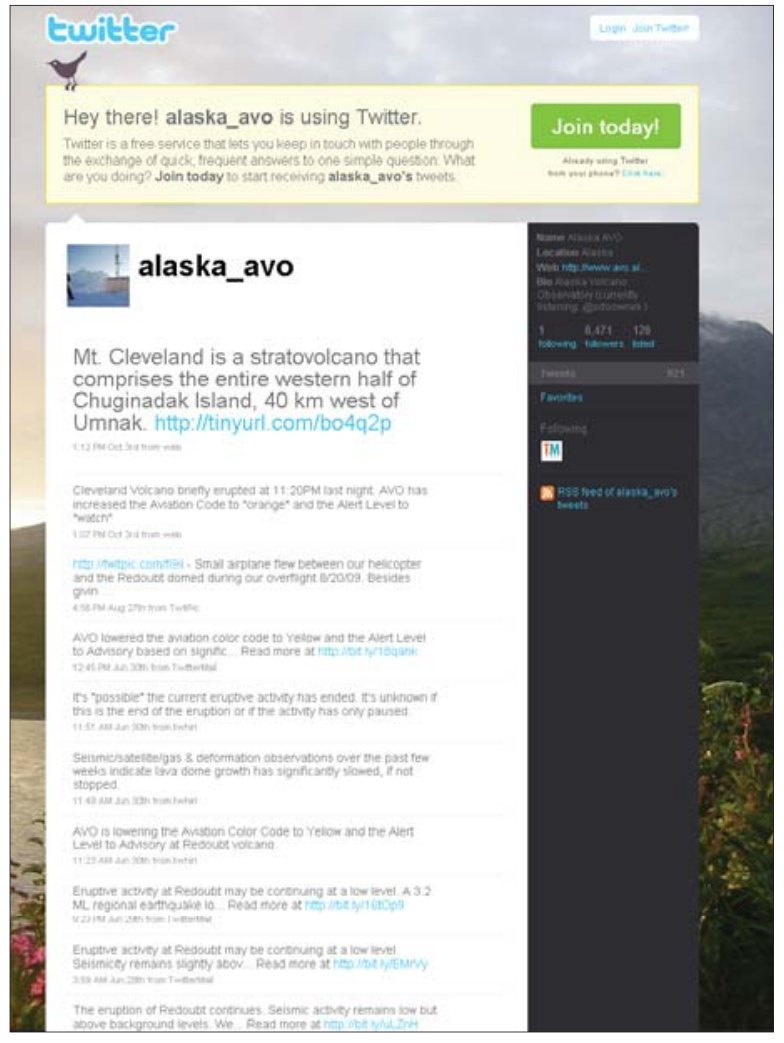




\section{ALASKA VOLCANO OBSERVATORY'S HAZARD NOTIFICATION SYSTEM (HANS)}

DGGS/AVO developed the Hazard Notification System (HANS) for distributing volcanic activity information collected by scientists to airlines, emergency services, and the general public. In the past year, data from HANS has been used by airlines to make decisions about diverting or canceling flights during the eruption of Mount Redoubt.

HANS was developed to provide a single system that each of the five U.S. volcano observatories could use for communicating and storing volcanic information about the $160+$ potentially active U.S. volcanoes. The data fill ten tables and nearly 100 fields, and are now stored in a common format among observatories. The information can be custom-formatted for different agency partners, such as the International Civil Aviation Organization (ICAO). Currently, HANS has about 4,500 reports stored; on average, two to three reports are added daily.

HANS (in its most basic form) consists of a user interface for entering data into one of many release types (Daily Status Reports, Weekly Updates, Volcano Activity Notifications, etc.); a database holding previous releases as well as observatory information such as email address lists and volcano boilerplates; and a transmission system for formatting releases and sending them out by email or other web-related system.

The user interface to HANS is completely web based, allowing access by our observatory scientists from any computer connected to the internet, onsite or off. The underlying database stores the observatory information and drives the observatory and program websites' dynamic updates and archived information releases. HANS also runs scripts for generating several different feeds including the Volcano Status Map on the USGS Volcano Hazards Program website.

Each observatory has the capability of running an instance of HANS. There are currently three instances of HANS and each instance is synchronized with all other instances using a master-slave environment. Information can be entered on any node-slave nodes transmit data to the master node, and the master retransmits that data to all slave nodes. All data transfer between instances uses the Simple Object Access Protocol (SOAP) as the envelope

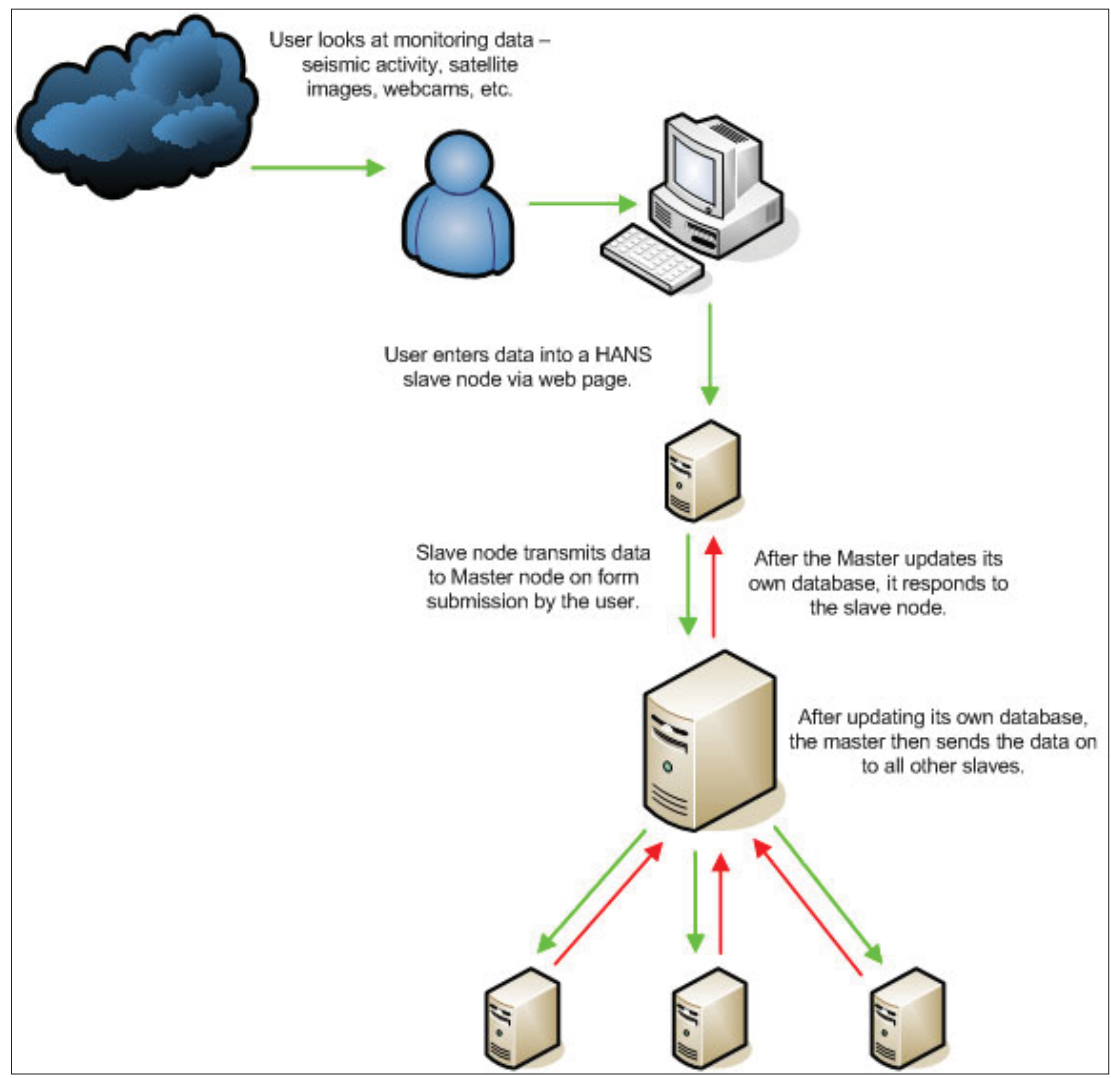
in which data is transmitted between nodes.

The HANS data synchronization not only works as a backup feature, but also acts as a simple fault-tolerant system. Information from any observatory can be entered on any instance, and still be transmitted to the specified observatory's distribution list, which provides added flexibility if there is a disruption in access from an area that needs to send an update. Additionally, having the same information available on the volcano program's multiple websites is necessary for communication of our scientists' most up-todate information.

This figure shows how data flows throughout HANS, from user input to slave nodes. 


\section{1,200 VENTS-INVENTORY OF QUATERNARY VOLCANIC VENTS IN ALASKA}

The Alaska Volcano Observatory currently uses an informal set of names for about 140 volcanoes—some names refer to large, complex volcanic centers, while others indicate only a specific cone. To better describe the nature and character of Quaternary Alaska volcanism, we have developed a database of all known Quaternary Alaska volcanic vents. Starting from this list we will build a fresh hierarchical naming structure that includes vent clusters, parasitic flank vents, polygenetic strato- and shield volcanoes, volcano groups, and larger volcanic centers. This will aid in discussing volcanoes as well as in interpreting spatial and temporal patterns of volcanism.

Each vent has been given a text description, linked to published and unpublished information sources, and classified according to youngest age of volcanism, chemistry, and geomorphology. The current vent database contains:

- 97 vents with historical or suspected historical eruptions

- 240 vents with Holocene or suspected Holocene eruptions

- 551 vents with Pleistocene or suspected Pleistocene eruptions

- 316 vents with Quaternary/Tertiary or suspected Quaternary eruptions

Of these 1,204 vents, roughly 130 are felsic (rhyolite, rhyodacite, dacite); the rest are basalt, basaltic andesite, and andesite. There are 100 stratovolcanoes on this list, 330 monogenetic basaltic cones, and 160 domes. Although they are difficult to count as single "vents," this effort has also enumerated 24 shield volcanoes. This database captures locations of vents that have been described in the geologic literature. Even now, additional vents are being newly discovered both on land and on the ocean floor.

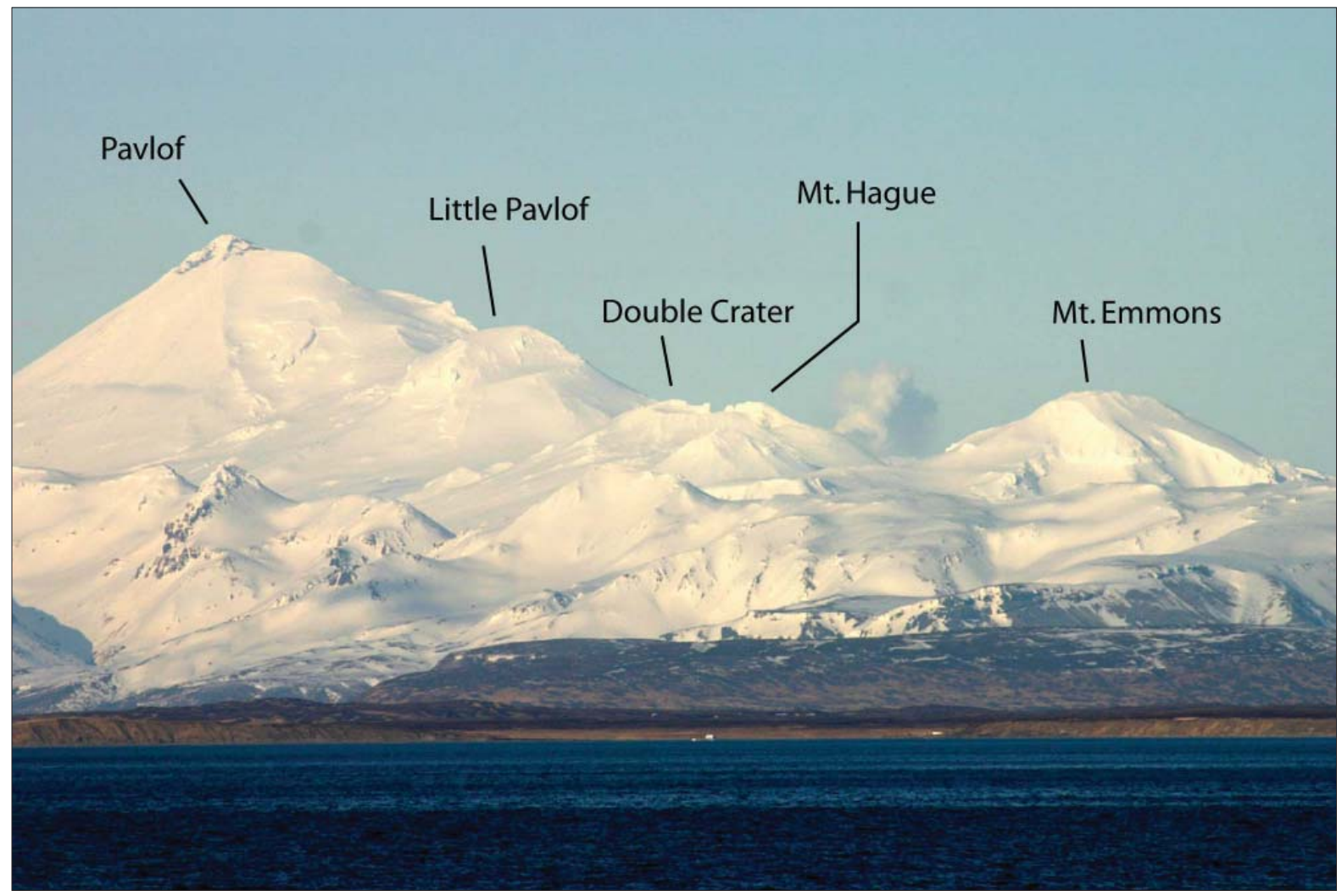

An example of multiple Quaternary volcanic vents, all stratocones, and part of the Emmons Lake Volcanic Center (ELVC). Pavlof has had historical eruptions, and is often enumerated separately from the ELVC. Mount Hague has an active fumarole field, and its vapor is visible in this image. Emmons, Hague, and Double Crater are within Emmons caldera, while Pavlof and Little Pavlof are not. In addition, most of these stratocones have flank vents that feed large lava aprons. (Photograph by Nathan Foster, annotated by Chris Waythomas, AVO/USGS, April 16, 2005.) 


\section{QUATERNARY VOLCANOES OF SOUTHEASTERN ALASKA}

In June 2009, DGGS/AVO geologist Kate Bull began participating in an ongoing collaborative project with the U.S. Geological Survey and U.S. Forest Service to identify and characterize Quaternary volcanoes in Southeast

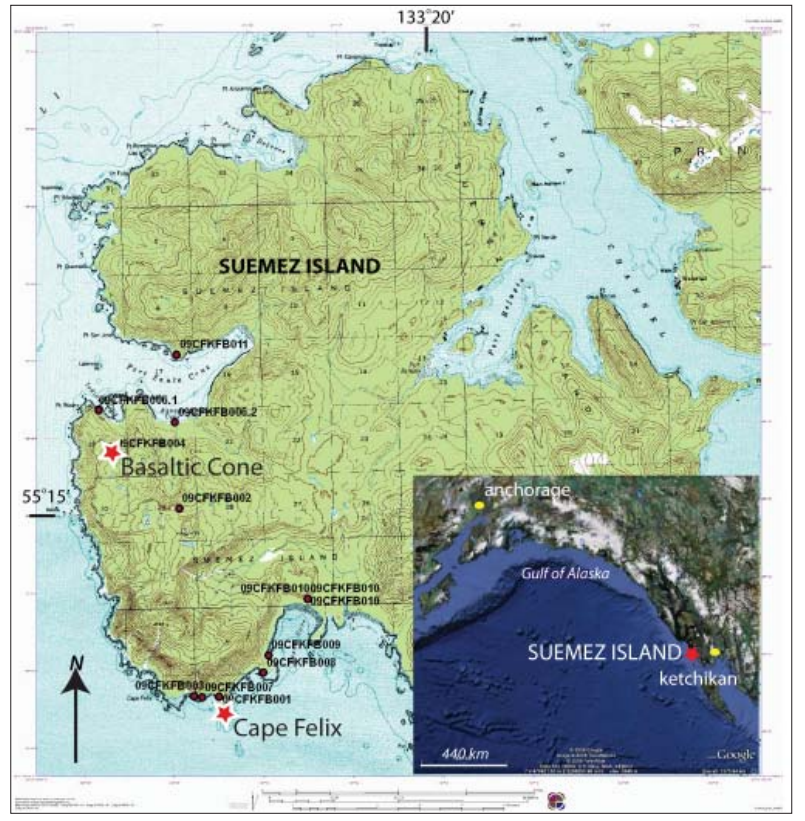

Figure 1. Location of study area and sample locations on Suemez Island

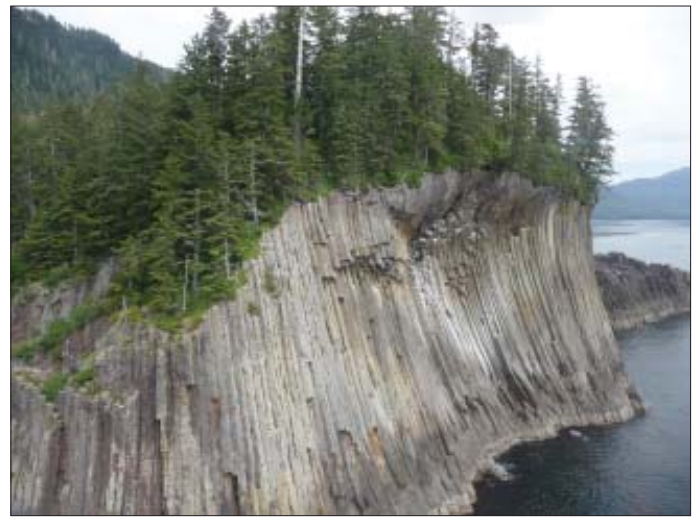

Figure 2. Columnar jointed volcanic deposits exposed in seacliffs on Suemez Island. of samples collected at Painted Peak, north of Suemez Island, suggest that Painted peak is a palagonitized tuff cone, whose deposits may be similar to those at Okmok volcano on the Aleutian chain.

Future Work \& Products: Further work on Suemez Island deposits will focus on petrography, data compilation, and an initial interpretation of the depositional setting of Suemez Island volcanoes. Additional fieldwork is planned in 2010 in the Suemez area as well as at other Quaternary volcano locations such as Painted Peak. The collaborators plan to publish a USGS paper that describes the Quaternary volcanoes of Southeast Alaska.

Data Analysis: Samples of lava flows from Suemez Island have been submitted for thin sections, chemical analysis and dating; results are pending. Petrography

Alaska. Many of these volcanoes had not been idenprior to this regional study, and few had been cribed in any detail. Bull joined the others for five investigating volcanic deposits on Suemez Isoff the west coast of Prince of Wales Island, west side of Suemez, where multiple vents had been identified and obsidian sources of ancient tool-

Field Investigations: One day of helicopter-supported fieldwork complemented coastal mapping by boat and foot. At Cape Felix, human-worked obsidian flakes lie on the floor of caves carved from a rhyolite dome. The dome is locally flow-banded and is glassy at its margin, suggesting a quenched contact with marine mudstone and trachyte. Perlite textures indicate the quenched glass hydrated, cracked, and subsequently altered (fig. 3). Varying orientation of columns in trachyte sea cliffs suggest deposition against glacial ice, supporting new dence of coastal glaciers in the Holocene. New raetric dates from the UAF chronology lab indicate a basaltic cone northwest and several hundred metrache 1). Laminated, fluidal, and blocky textures in deposits forming the basaltic cone indicate a complex maar- or tuff-ring-related depositional sequence. Aguada Cove creek and beach deposits include rounded cobes of yellow, likely palagonitized, pyroclastic flow deposits. 


\section{DIGITAL GEOLOGIC DATABASE PROJECT}

In 2000, the Alaska Division of Geological \& Geophysical Surveys (DGGS) initiated development of a geologic database system that provides the architecture for consistent data input and organization. The database system includes data identification and retrieval functions that guide and encourage users to access geologic data online. This project was initially part of the federally funded Minerals Data and Information Rescue in Alaska (MDIRA) program; ongoing data input, use, and maintenance of the database system are now part of DGGS's normal operations supported by State General Funds.

The Digital Geologic Database Project has three primary objectives. The first is providing a spatially referenced geologic database system in a centralized, secure information architecture with networked data access for new and legacy DGGS geologic data. The second objective is developing functional online interfaces that allow the public to find and identify geologic data available from DGGS and then view or download the selected data. The third objective integrated DGGS's minerals-related data with data from other agencies through the MDIRA website http://akgeology.info.

During the first eight years, the project work group established a secure and stable enterprise database structure, started loading data into the database, and created Web-based user interfaces. As a result, the public can access DGGS and USGS reports and maps, and DGGS project digital data through a search page on the DGGS website http://www.dggs.dnr.state.ak.us/pubs, and access DGGS geochemical data though a search engine http://www. dggs.dnr.state.ak.us/webgeochem. Users can browse DGGS reports and maps, along with geology and minerals reports from other agencies, through an integrated information portal at the AKGeology.info website http://akgeology.info.

During 2010, the project team will support ongoing DGGS MDIRA projects by extending the DGGS enterprise database, and designing web-based search engines for the Alaska Geologic Map Index, Geochronologic Database for Alaska, and Geologic Materials Center Database projects. The team is expanding the database content to include energy resource geologic data and to provide index data to national databases such as the National Geologic Map Catalog http://ngmdb.usgs.gov/ngmdb/ngm_catalog.ora.html and National Geological and Geophysical Data Preservation Program http://datapreservation.usgs.gov/.

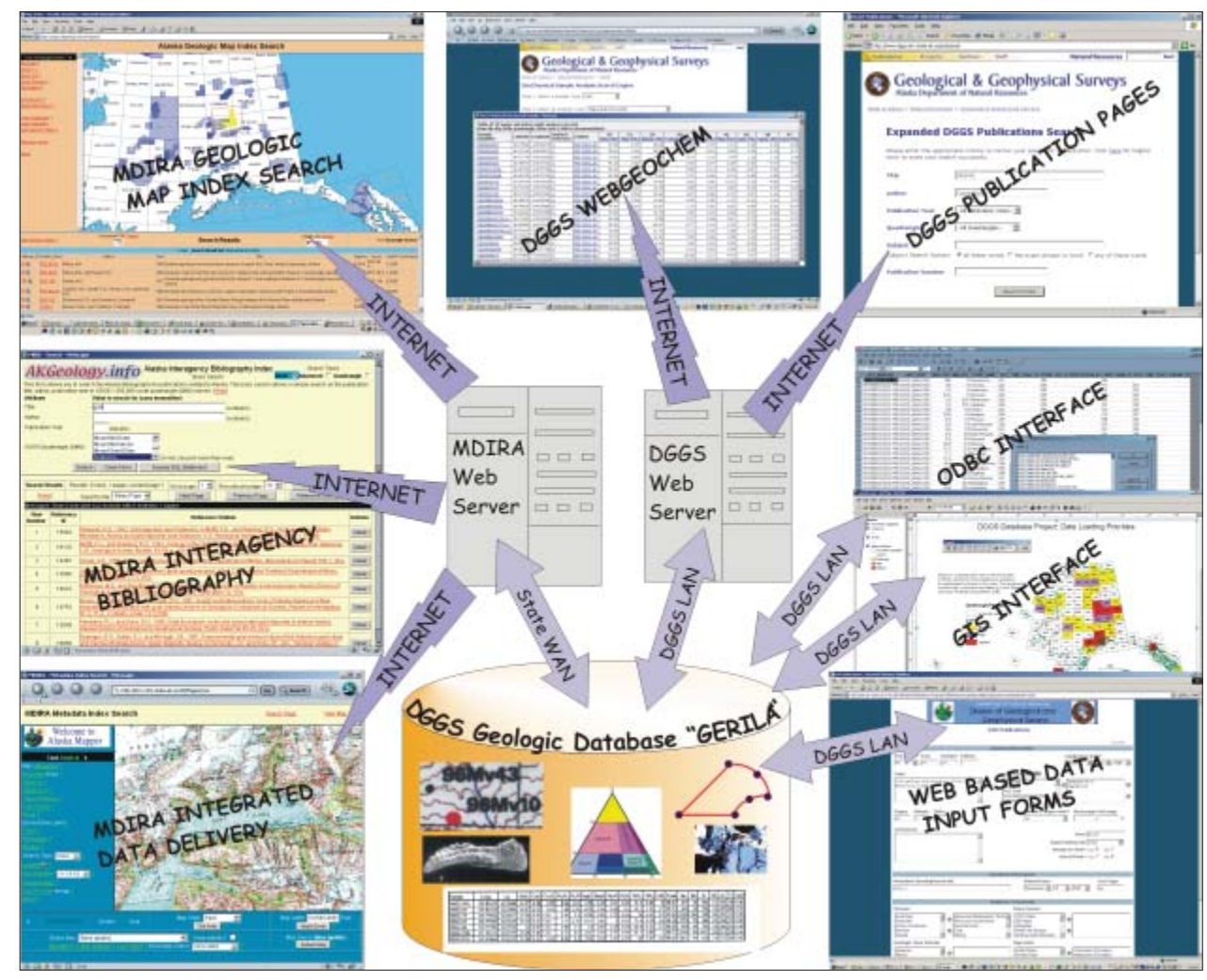

Contacts: Larry Freeman, 907-451-5027, larry.freeman@alaska.gov Jennifer Athey, 907-451-5028, jennifer.athey@alaska.gov 


\section{GEOLOGIC MATERIALS CENTER ONLINE SAMPLE CATALOG}

The Alaska Geologic Materials Center (GMC) is the central repository in which geologic samples collected throughout Alaska are cataloged, stored, and studied. This archive facility holds geologic sample materials from a multitude of sources including government agencies, mineral companies, and oil and gas companies. For more details on the holdings at the GMC, please see the web page http://www.dggs.dnr.state.ak.us/?link=gmc overview\&menu_link=gmc. DGGS is continuing the development of a mobile, web-based inventory system for rock sample and hard-rock drill core materials housed at the GMC in Eagle River. Initially funded by Minerals Data and Information Rescue in Alaska (MDIRA) program, DGGS will carry out the completion of this development project using General Funds.

The ultimate goals of the GMC on-line sample catalog are to provide a secure, reliable catalog of the geologic materials held by the GMC and to provide public users with web-based search tools for samples of interest. The focus of the project is to provide a framework for a single digital index and catalog of DGGS and mineral industry cores and samples. While accomplishing that direct goal, the project will integrate and upgrade the existing inhouse digital catalog of oil and gas industry samples and the catalog of U.S. Bureau of Mines and U.S. Bureau of Land Management mineral and coal samples into the same database and online search engine.

The development team from DGGS and Land Records Information Section (LRIS) has completed beta test versions of two components for this project: (1) a bulk data-loading application that will allow GMC staff to load inventory data into a centralized, secure database; and (2) a public GMC search engine prototype serving the bulk loaded data, with text-based and map interface query options. We plan to improve on the initial design of these applications, enhancing the map interface to utilize Google Maps. The design allows for future extension of the application to achieve the third objective of a sample tracking and inventory control system.

Integration of the GMC catalog with the DGGS relational database will provide a direct connection between sample locality descriptions, DGGS analytical data, DGGS publications, and archived sample materials. Final production deployment of the application and data, expected in 2010, will provide both web-based geographic and simple text searches for all the physical sample holdings of the GMC. The search results will include documentation of locality information, and provide condition of the archived materials and detailed analytical information where available.

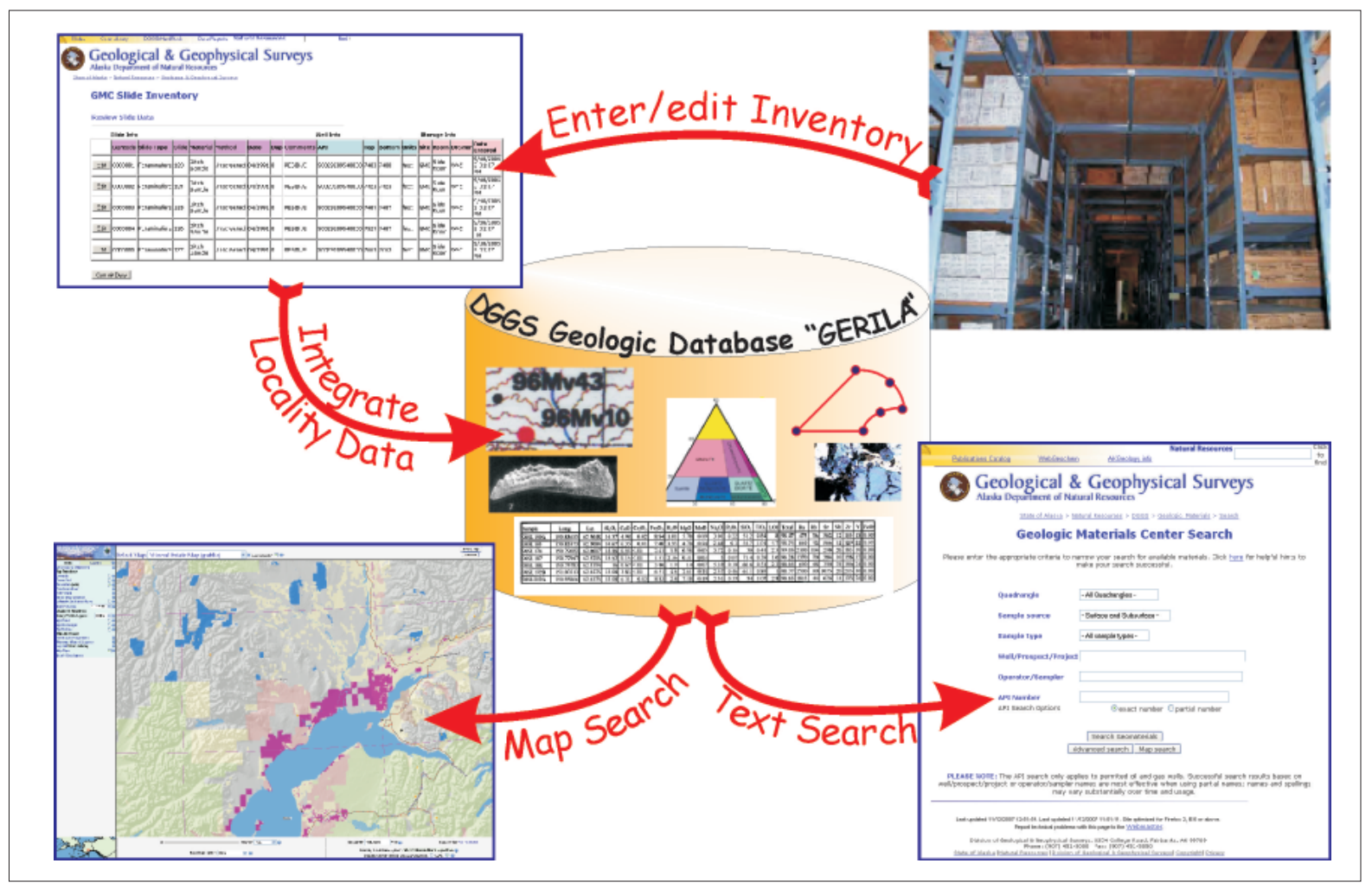

Contact: Susan Seitz,907-451-5052, susan.seitz@alaska.gov 


\section{WEBSITE DEVELOPMENT}

Since its creation in the late 1990s the DGGS website has grown from a few static HTML pages to the division's primary mechanism for distribution of geologic publications and information. As the cumulative result of a series of multi-year projects, our current website allows our online customers to search our publications catalog, download DGGS and USGS publications, view and download DGGS geochemical data, and find current information about various geologic projects and topics of interest. Public users can currently select and download (at no charge) more than 7,000 text reports, 9,000 oversize sheets, and nearly 100 GIS datasets.

In 2007, DGGS implemented a significant code and design renovation to the DGGS website. The outdated HTML pages were converted to PHP files. The PHP format allowed us to replace our tabular menu structure with a dynamic, context-sensitive navigation menu. User response to the new site design has been highly positive and, as a result, we have continued to develop the design and populate the site content while expanding the PHP framework.

A major new feature that was added to the website in 2009 is the addition of the Geologic Materials Center Data Report Series (GMC). Reports of the GMC series contain analytical and interpretive data resulting from thirdparty testing of sample material borrowed from the Alaska Geologic Materials Center. These reports are produced by the third-party agency or the company they hired to conducted the sampling and analysis.

In late FY08 we began work to update our online Guide to Geologic Hazards in Alaska. This guide provides general information about geologic hazards in Alaska, links to timely geohazard advisory information, links to pertinent DGGS and USGS publications, and geohazard publication listings grouped by Alaska Coastal Management Program (ACMP) coastal district. Work for this project is funded by the ACMP Enhancement Grants Program. Project objectives are to (1) update the information included in the online Guide to Geologic Hazards in Alaska (maps, reports, and website resources), (2) improve hazards map search capabilities by incorporating a digital map-based interface to allow users to graphically select specific geographic areas about which they need geologic-hazards information, and (3) maintain the currency of the delivered data.
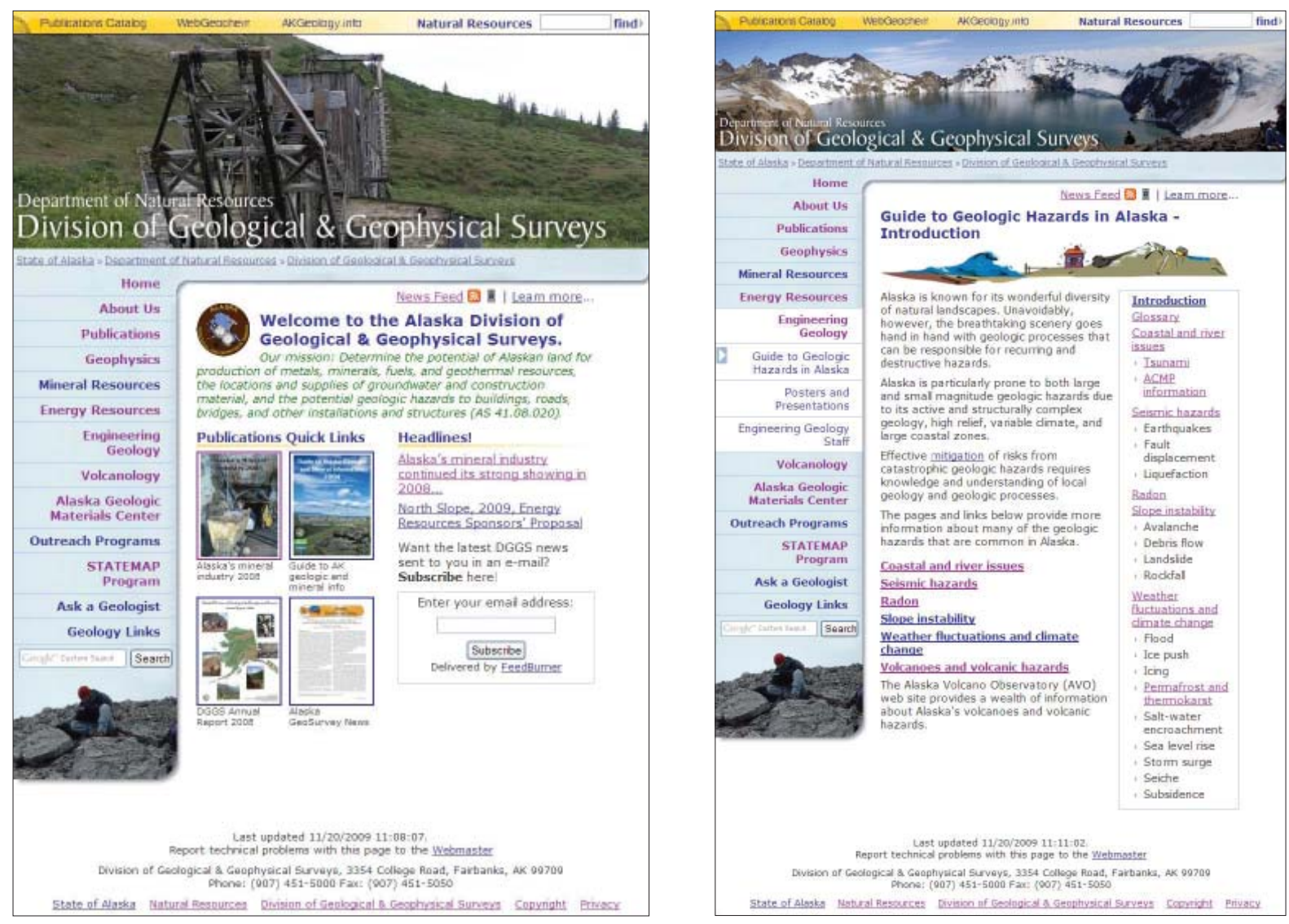

Contact: Simone Montayne, 907-451-5036, simone.montayne@alaska.gov 


\section{PUBLICATIONS AND OUTREACH PROJECT}

Staff from the Publications Project publish and distribute the geologic data that has been collected, analyzed, and assembled by geologists in the Minerals, Energy, Engineering Geology, and Volcanology sections of DGGS. Team members are involved in many of the division's publication and outreach activities. Some of the functions they carry out are:

- Design, digitally assemble, edit, and oversee final production of technical and educational geologic maps, reports, and informational publications in printed and digital formats.

- Prepare an annual report for the Legislature and public, required by statute and written by division staff, summarizing DGGS activities and products and communicating plans for its future projects.

- Publish two annual newsletter issues that communicate DGGS progress and announce the latest publications.

- Prepare displays and represent the division at geologic conferences and meetings by providing staff and assembling and transporting the display booth.

- Staff DGGS's information center in Fairbanks, providing

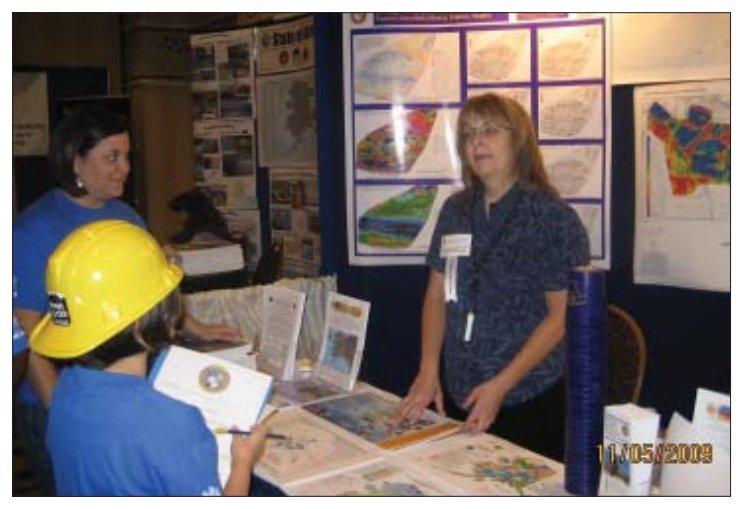
information in response to numerous inquiries about Alaska's geologic resources and hazards.

- Manage sales and distribution of DGGS's printed and online geologic reports, maps, and digital data.

- Review metadata for each project and file it in the appropriate digital repository. Assist other staff members as they prepare metadata for spatial data they will distribute.

- Manage DGGS's reference library so that reports, maps, and other data are available and publications are on hand that geologists need when they prepare geologic products.

- Maintain a complete collection of Alaska-related publications produced by the U.S. Geological Survey, the former U.S. Bureau of Mines, and the U.S. Bureau of Land Management; collect and maintain other Alaska-related publications as needed.

- Participate in school outreach activities such as helping prepare classroom presentations, judging science fair entries, and helping teachers by presenting earth science units.

The publications produced and distributed by this group record and preserve geologic data such as: Definitive statistics for Alaska's mineral industry; detailed (1:63,360-scale) bedrock, surficial, and engineering geologic maps for specific areas in the state; sources of Alaska's geologic information; annual information about DGGS's programs and accomplishments; air-

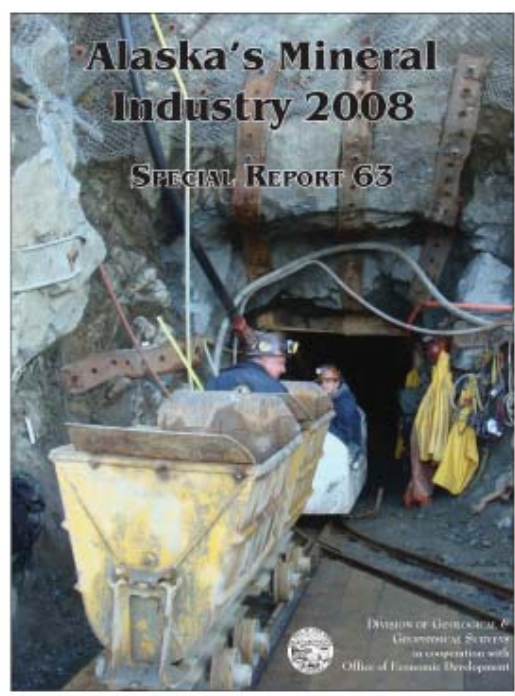
borne geophysical data for areas with promising mineralization; and educational brochures and pamphlets explaining Alaska's geology or natural-science features. Some of the most recent DGGS publications include Alaska's Mineral Industry 2008; a geologic map of the Kanayut River area, Chandler Lake Quadrangle; a map of the geology of the Cobblestone Creek-May Creek area, east-central Brooks Range Foothills; a newsletter highlighting DGGS's Geologic Materials Center in Eagle River; a volume summarizing preliminary results of recent field investigations in the Homer-Kachemak Bay area; a guidebook to the Dalton Highway prepared for the 9th International Conference on Permafrost; and surficial-geologic, engineering-geologic, and reconnaissance permafrost maps of the Alaska Highway corridor, Delta Junction to Dot Lake.

Publications are available in paper format (plotted as needed and sold for the cost of printing) and as PDF documents and scanned compressed maps on the DGGS web page (available for download at no charge). An increasing number of digital datasets are available on the publications pages as additional products. Work continues in FY2010 to increase the availability of digital datasets from which GIS maps are produced, so that customers can manipulate data as they choose; and publishing documents in digital format first, then using the digital publication to produce a paper copy when necessary. The geological and geophysical data and reports published by DGGS encourage wise management and exploration of Alaska's natural resources and mitigation of risks from the state's geologic hazards.

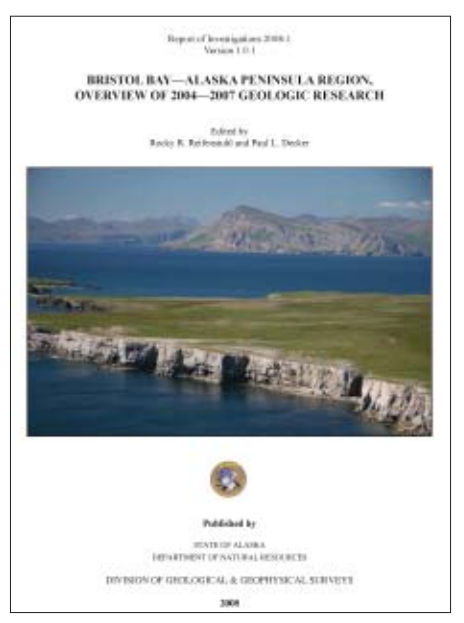




\section{NATIONAL GEOLOGICAL AND GEOPHYSICAL DATA PRESERVATION PROGRAM}

The Alaska Division of Geological \& Geophysical Surveys (DGGS) has, as its statutory mission, the responsibility for collecting, archiving, managing, and disseminating geological and geophysical data on the subsurface energy resources, mineral resources, and geologic hazards of the state. During the past 10 years, through the federally funded Minerals Data and Information Rescue in Alaska (MDIRA) program, DGGS has cataloged and greatly improved the condition of its geological and geophysical data archive, has upgraded its data management system, and has begun disseminating this data through the internet.

DGGS is continuing its data preservation goals by participating in the federally funded National Geological and Geophysical Data Preservation Program (NGGDPP). This program is committed to assisting state geological surveys with four data preservation priorities: (1) inventory geological and geophysical data collections to assess their data preservation needs, (2) create site-specific metadata for individual items in those data collections, (3) create new digital infrastructure or improve the state's existing digital infrastructure for archiving and preserving these data, and (4) rescue geologic data at risk through "special needs" awards.

During FY2009, DGGS directly addressed NGGDPP priorities two and three. Our database development team created site-specific metadata for three DGGS geologic data collections: (1) data reports on core samples that have been taken on temporary loan from the GMC for analysis, (2) geochemical analyses of rock, soil, and stream sediment samples collected during projects involving DGGS geologists, and (3) geochronology analyses of samples collected during projects involving DGGS geologists. In order to serve the metadata records to the National Digital Catalog, DGGS enhanced its digital infrastructure by implementing a Web Feature Service (WFS) interface. The DGGS WFS is currently in beta-test mode for internal staff

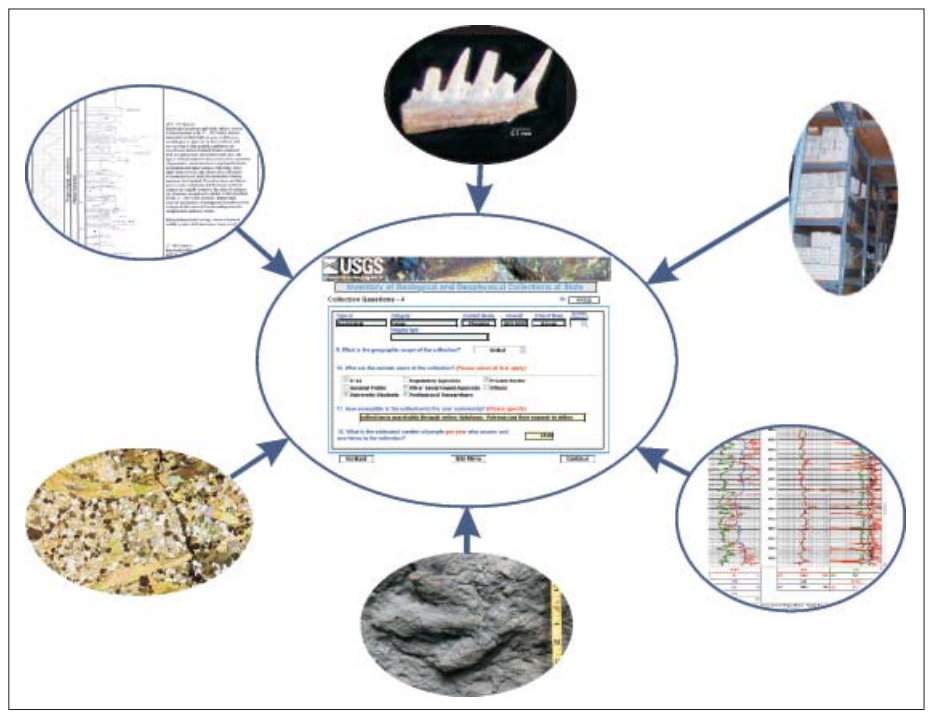
to import data into Geographic Information Systems (GIS) software. However, the WFS allows the site-specific metadata records to be harvested and synchronized automatically by the National Catalog system, thus freeing DGGS staff members of the manual task of uploading data to an additional database on a regular basis. The DGGS database is continually updated and quality checked by existing business processes.

By the end of 2009, DGGS also provided additional metadata records to the National Digital Catalog using the same infrastructure for the following datasets: core samples and drill cuttings stored at the Alaska Geologic Materials Center (GMC), glass slide collection of processed samples at the GMC, and the hard-rock surface samples collected by DGGS staff.

DGGS has submitted a proposal for the FY2010 phase of NGGDPP, in which we intend to focus efforts on the agency's energy-related datasets. Site-specific catalog metadata will be prepared and submitted for published data from two energy-related collections: (1) porosity and permeability data and (2) organic geochemistry analyses of samples collected during projects involving DGGS geologists. In addition, DGGS requested funds to rescue the valuable Amchitka hard-rock mineral core and coal-bed methane core samples stored in deteriorating boxes at the Alaska Geologic Material Center (GMC). Access to these collections through the National Digital Catalog will improve their accessibility to both in-state and national users.

This project is funded by the U.S. Geological Survey as part of the National Geological and Geophysical Data Preservation Program, authorized by the National Energy Policy Act of 2005. For more information on this program, please go to the web page: http://datapreservation.usgs.gov 


\section{GIS-IT INFRASTRUCTURE PROJECT}

The DGGS Information Technology (IT) staff delivers computer and network services to employees and streamlined web access to external users. DGGS in 2008 made major improvements to its network to enhance those services. We continue to take advantage of LANDesk for automated asset tracking and management as well as the remote installation of software packages and updates. Employing LANDesk's capability to control desktop administration remotely has greatly reduced response time and increased productivity.

With the overwhelming success of the disk-based backup system implemented in the early part of 2008, we moved forward with installation of a 48-terabyte volume. This new storage volume is dedicated to the preservation of full and incremental backups of all servers. Since the introduction of this system, it has proven itself a fundamental tool for the recovery of failed hard drives in both desktops and laptops, saving days of lost productivity. The value of recovered data is often immeasurable when dealing with one-of-a-kind geologic data collected over several field seasons.

The primary fileserver's drive space was reconfigured for greater redundancy and for simpler error recovery. The data was migrated to a RAID5 array, while the operating system (OS) was migrated to a RAID1 array. This configuration prevents data loss in the event of a failure of either of the two drives containing the operating system or any one of the 16 data drives.

During the reconfiguration, we also upgraded the primary data storage volume from 4.5 terabytes to 12.5 terabytes, with the addition of a Dell MD1000 disk array. The addition of this storage subsystem made it possible for other sections at DGGS to continue the process of scanning handwritten field notes collected by geologists and organizing them into a logical archiving structure. This project is expected to continue as more geologic data are collected each field season and archiving processes become standardized throughout the division.

The eruption of Mount Redoubt in the spring brought the attention of the world to the Alaska Volcano Observatory (AVO; see separate

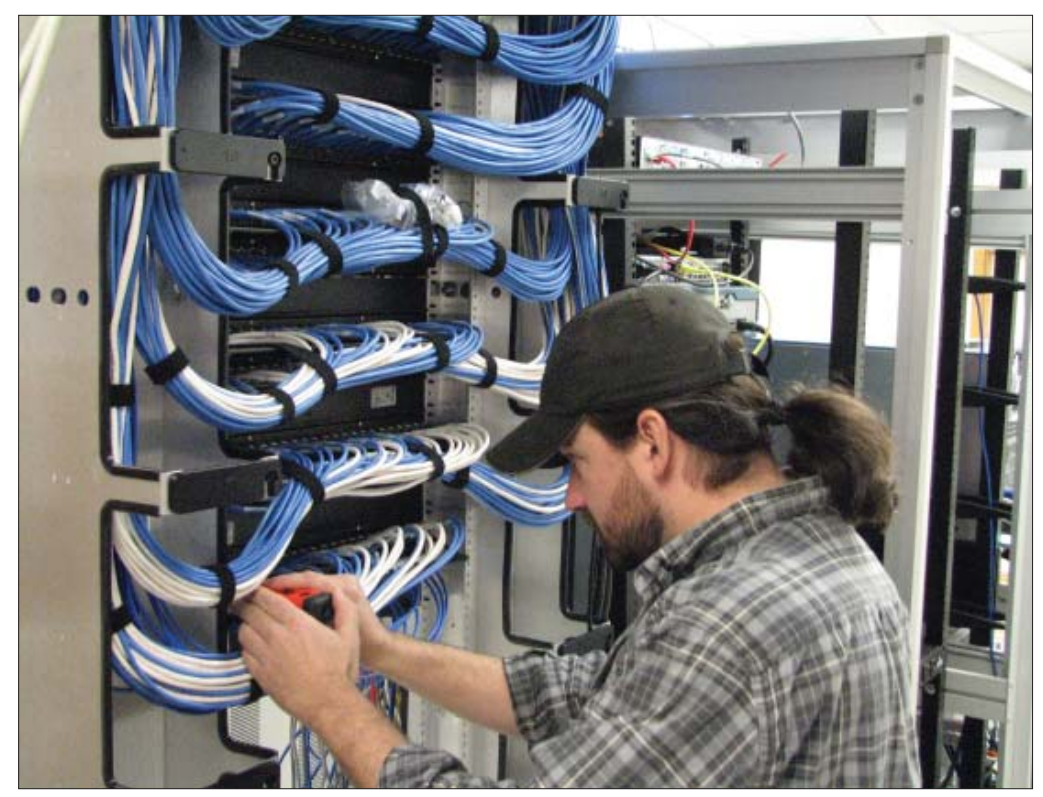
briefing paper) for real-time updates. To accommodate the huge increase in public website accesses during such major events, we facilitated the installation of a redundant web server at the DGGS facility. This server communicates with the main AVO server every 30 minutes and automatically synchronizes any changes that have occurred between them. The two servers are then virtually identical, allowing load balancing so that neither server is overloaded. Load sharing virtually eliminated downtime during this event, even in the face of several days of front-page features by CNN.com and other national news organizations and the resulting exponential increases in website hits.

The Geologic Materials Center was connected to the State of Alaska Wide Area Network in 2009 as well. With this new connection, sharing of data with the main DGGS office and others is easier, more secure, and much faster. It also allows for the GMC staff to use the existing ArcGIS licenses, eliminating several thousand dollars in additional costs each year. 


\section{ALASKA GEOLOGIC MATERIALS CENTER}

The Alaska Geologic Materials Center (GMC) in Eagle River holds nonproprietary rock core and cuttings that represent nearly 12 million feet of exploration and production drilling on Federal, State, and private lands of Alaska, including the Alaska outer continental shelf. Additionally, the collection holds more than 230,000 feet of diamond-drilled hard-rock mineral core; rock materials from more than 1,500 oil and gas exploratory or production wells; rock core from nearly 1,100 exploratory hard-rock mineral holes; samples for some geotechnical test wells; and numerous surface rock samples. The collection also includes extensive geochemical data, petrographic thin sections, and paleontological glass slides derived from this rock.

The GMC is operated by the Alaska Department of Natural Resources, Division of Geological \& Geophysical Surveys, with support from cooperating government agencies that include the U.S. Bureau of Land Management, U.S. Geological Survey, U.S. Minerals Management Service, and Alaska Oil and Gas Conservation Commission. The basic mission of the GMC is to archive all worthwhile rock samples collected in Alaska and on the Alaska outer continental shelf. Chief users of the GMC are the oil and gas industry, although use by the minerals industry, government, engineering firms, and academic institutions is increasing.

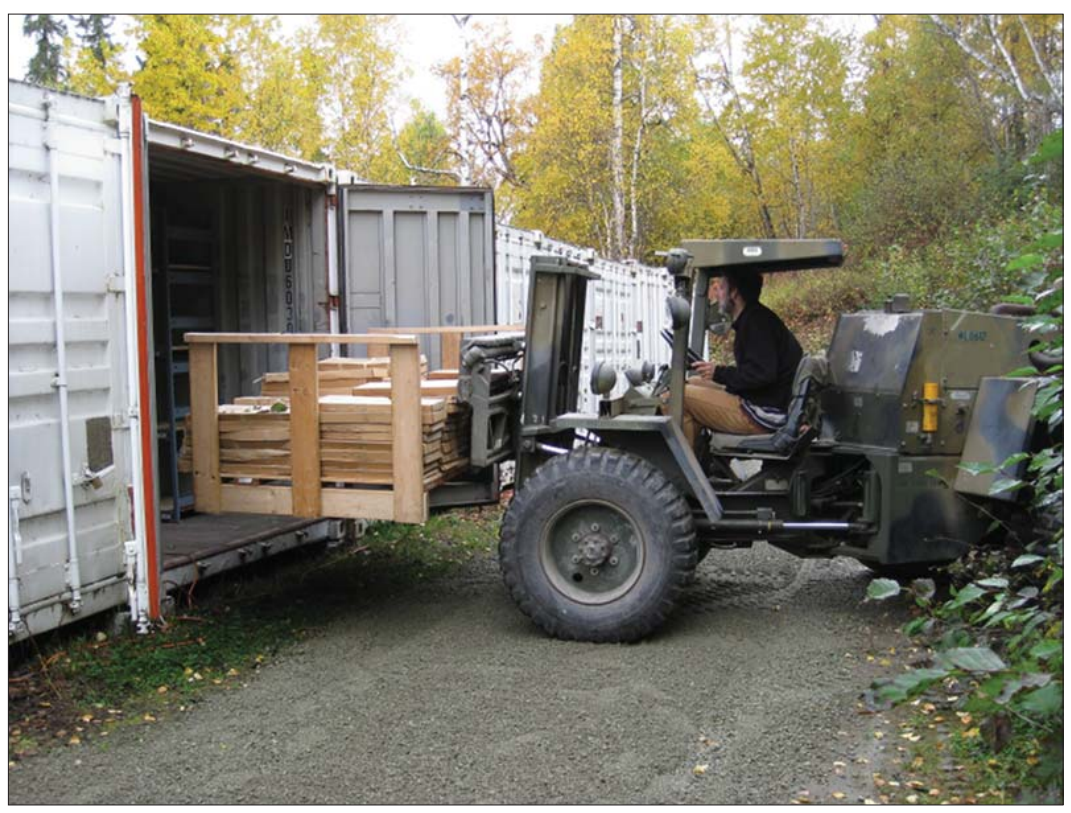

Many recent changes have occurred at the Geologic Materials Center. Dr. John Reeder retired in 2009 after serving 22 years as Curator. Dr. Reeder's passion for geology, teaching, and sharing his knowledge will be greatly missed. The DGGS and GMC staff thank John for his many years of dedication and hard work. Kenneth Papp, University of Alaska Fairbanks alumnus, formerly with DGGS and Alaska Energy Authority, was appointed the new curator in mid July 2009. In addition to a new curator, the GMC now has two full-time staff members (Jean

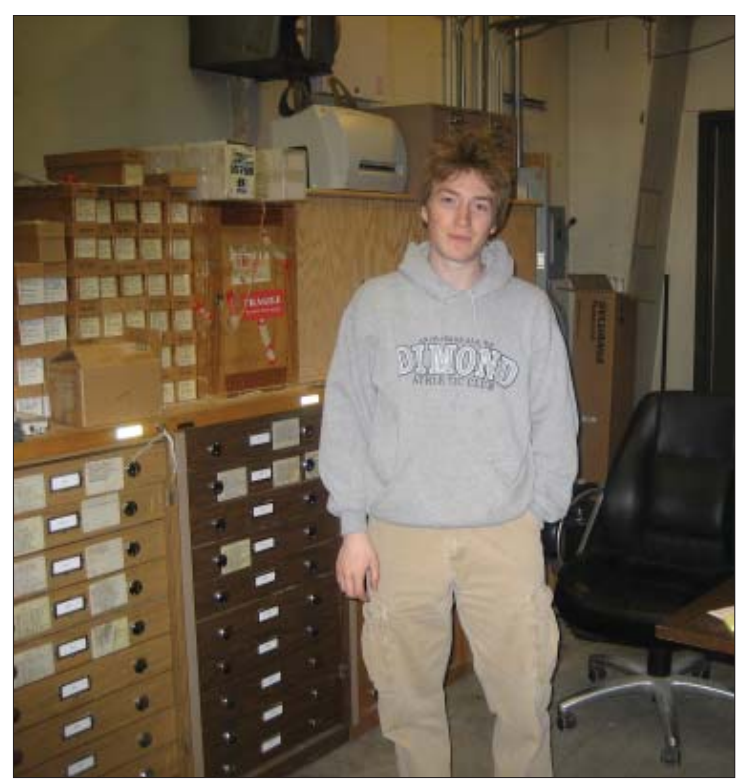
Riordan and Kurt Johnson), a contract curator, two volunteers, and four student interns.

The GMC crew has organized, documented, and detailed approximately 80 percent of the hard-rock material stored in $18+$ metal shipping containers ('conex boxes') as part of the GMC Database Inventory Integration project. Kurt Johnson and three interns, Joseph Skutca, Herbert Mansavage, and Josh Stucky, have moved, detailed, and indexed an impressive 1.3 million pounds (453 metric tons) of rock over the course of the summer. Their efforts have vastly improved the mineral-core database inventory, allowing staff to help users of the facility find information more quickly while onsite, using a set of future web-based search tools.

Contract curator and former Alaska State Geologist Don Hartman and GMC staff are working hard to make more room inside the main warehouse by detailing and reboxing the massive USGS (Henry Bender), NPRA, and Oxy 
collections. Currently, a majority of the material (cuttings) is stored in large, wooden boxes that are nailed closed. Reboxing this material will reduce the physical size of the collection by about one-third. It is critical to find ways to 'create' space as the aging main warehouse is quickly reaching full capacity. The GMC's complete inventory is at 160 percent capacity and includes 60 conex boxes to house the collection, 54 of which are occupied with samples.

Two subsets of core sample collections stored at the Alaska Geologic Materials Center are in need of immediate rescue. The samples are in danger of being lost because of the rotting core boxes in which they are stored and/or core deterioration caused by the introduction of moisture and multiple freeze/thaw cycles in outdoor, unheated shipping containers. The Amchitka core from the Aleutian Islands, originally drilled between 1967 and 1971 during a series of underground nuclear tests, would be prohibitively expensive to replace if lost, because of the remote collection site and extreme drilling costs. The preservation of this core is not only historically significant but is also of interest to researchers in many different fields of study. The second collection consists of valuable coal-bed meth-

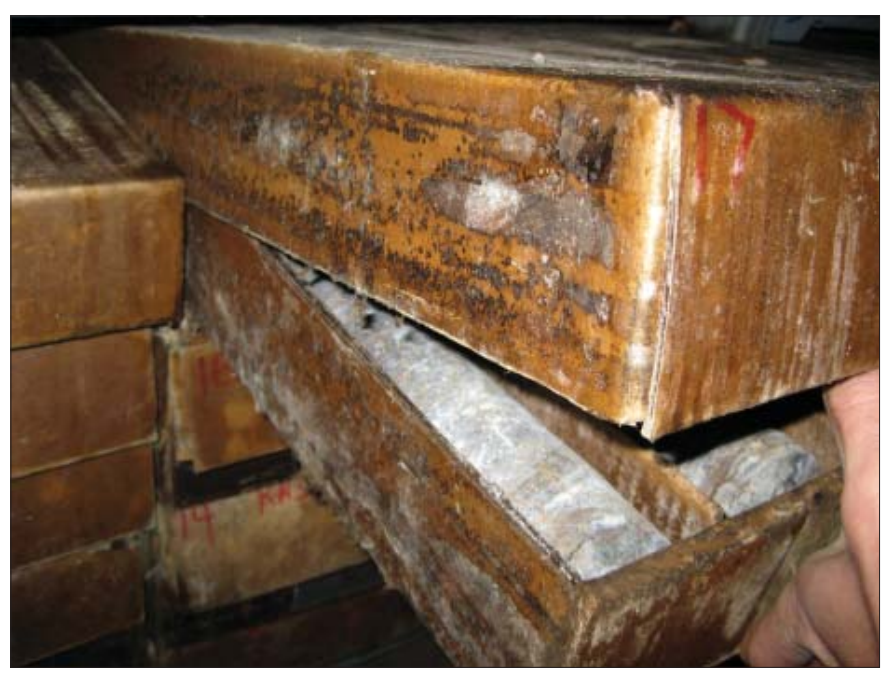
ane core samples integral to Tertiary geologic research and understanding young coal deposits. Boxes that contain the young, tan-colored lignite are completely rotting away and GMC staff has discovered that freshly broken lignite (covered in white, fibrous mold) exposes more mold growing throughout every possible pore space. The GMC recently requested federal funds to purchase 400 new (HX/HQ) core boxes to re-box and curate these irreplaceable core samples, with the hope that it may help ensure their preservation.

Intern Allison Empey, under the guidance of the curator and GMC staff, compiled documentation for the first Annual GMC Curator's Report. The report will highlight examples of priceless materials in need of curation and the GMC's plans to ensure the materials' protection and provide accessibility to the materials for all users of the facility. GMC staff is also actively researching storage methods, curation techniques, and policies that are less reactionary and more proactive, to prevent 'emergency' curation projects from occurring in the first place. Such policies could include a directive that all stored core from any drill site in Alaska be inspected periodically, regardless of the 2-year confidential period, or that it includes a sharper focus on soft sediment cores so that the core does not deteriorate as a result of environmental impacts and a lack of proper storage conditions.

Although the main responsibility of the GMC is to preserve and ensure the safety of the material stored at the facility, it is equally critical to make the material and its derived data accessible to the public. GMC staff has been involved in an ongoing push to acquire additional material details and to quality control the information stored in the ever-growing database. The next step is to provide users with a suite of online search tools to query the available materials at the GMC. Staff at the GMC is working with members of the DGGS Geologic Communications section to create form- and geospatially-based (Google Earth) search options that would distinguish between materials associated with the oil and gas and the hard-rock mineral inventories at the GMC. Query results would include first-order information such as well/borehole names, API numbers, number of boxes, full footage intervals, core size, material types (core, cuttings, thin sections, etc.) and second-order data such as box-level footage intervals, associated data reports, links to well-history information, and more. The GMC intends to have the GMC web-search interface available in Spring 2010. 


\section{PUBLICATIONS RELEASED IN 2009}

\section{ANNUAL REPORTS}

AR 2008. Alaska Division of Geological \& Geophysical Surveys Annual Report, by DGGS Staff, 2009, 82 p. Free

\section{GEOLOGIC MATERIALS CENTER REPORTS}

GMC 358. Original geologic core logs, sample records and corresponding assay logs for the Arctic Prospect of Northern Alaska; holes no. DH-1, DH-2, DH-3, DH-4, DH-5, DH-7 and DH-8, by Sperry-Sun Drilling Services, 2009, 97 p. Free

GMC 359. Geochemical analysis of core from the U. S. Navy Gubik TestWell No. 1 (3,491.5', 3,492', 3,577' and 3,599') and U. S. Navy Gubik Test Well No. 2 (1,849.7', 1,852.5', 1,856.5', 1,863' and 1,868'), by ConocoPhillips, 2009, 5 p. Raw data provided in excel table. Chromatograms included in PDF document. Additional data is available on DVD upon request. Free

GMC 360. Photomicrographs of Petrographic Thin Sections for the Inigok \#1, Peard Test Well \#1, and Prudhoe Bay State \#1 wells., by Shell International EP, Inc., 2009, 11 p., 1 disk. Additional data in TIFF format available on DVD. Free

GMC 361. X-ray Diffraction Analysis of: Drew Point \#1, East Simpson Test Well \#1, East Simpson \#2, Ikpikpuk \#1, Seabee \#1, W. Dease \#1 wells, by Talisman Energy Inc., and Core Laboratories, 2009, 17 p. Free

GMC 362. QFT (Fluorescence) Characterization for Inigok \#1, Milne Pt Unit KR \#A-01, Itkillik Unit \#1 wells, by Talisman Energy Inc., and Core Laboratories, 2009, 14 p. Free

GMC 363. Petrographic Analysis of Samples from 9 NPRA Wells, North Slope, Alaska: East Simpson \#2, West Dease \#1, J.W. Dalton \#1, East Simpson \#1, Seabee \#1, Drew Pt. \#1, Topagoruk Test \#1, South Meade \#1, Ikpikpuk \#1, by FEX L.P., 2009, 33 p. Excel files of grain size data and point count data available. Free

GMC 364. Advanced Rock Properties Study on Core samples from 8 wells in Alaska: Drew Pt \#1, East Simpson Test Well \#1, East Simpson \#2, Ikpikpuk \#1, J.W. Dalton \#1, Seabee \#1, Topogoruk Test \#1, and W. Dease \#1, by Talisman Energy Inc., and Core Laboratories, 2009, 154 p. Free

GMC 365. Hydrocarbon Extracts From Core Chip Samples: Ivishak Unit \#1, Susie \#1, Gubik Test \#2, Square Lake Test Well \#1, by FEX L.P., and Weatherford Laboratories, 2009, 299 p. Free
GMC 366. Makushin Geothermal Project ST-1 Core 2009 re-sampling and analysis: Analytical results for anomalous precious and base metals associated with geothermal systems, by Alaska Earth Sciences, 2009, 1 p. Free

GMC 367. Sidewall core analyses from 32 Alaska OCS wells, by Minerals Management Service, and Core Laboratories, 2009, 3 p., 1 disk. Additional data on DVD available upon request. Free

GMC 368. Geochemical analysis (total organic carbon, rock-eval, bitumen geochemistry, vitrinite reflectance) from the Ikpikpuk \#1, W.T. Foran \#1, J.W. Dalton \#1, Seabee \#1, Sentinel Hill, Titaluk Test \#1, N. Inigok \#1, Drew Pt. \#1, Gubik Test \#1, Inigok \#1 and Oumalik Test \#1 wells, by Petro-Canada Oil and Gas, and JP Petrographics, 2009, 1 p. Free

\section{GEOPHYSICAL MAPS \& REPORTS}

GPR 2009-1. Line, grid, and vector data, and maps for the airborne geophysical survey of the Slate CreekSlana River Survey, Chistochina mining district, south-central Alaska, by Burns, L.E., Fugro Airborne Surveys Corp., and Stevens Exploration Management Corp., 2009, 18 sheets, scale 1:63,360, 1 disk. 1 database, 6 grids, and 6 vector files available on DVD for $\$ 10.18$ sheets in all, individual sheets available for $\$ 13$ each.

\section{GUIDEBOOKS}

GB 9. Dalton Highway Field Trip Guide for the Ninth International Conference on Permafrost, by Walker, D.A., Hamilton, T.D., Ping, C.L., Daanen, R.P., and Streever, W.W., 2009, 104 p. A supplement to Guidebook 4, "Guidebook to permafrost and related features along the Elliott and Dalton Highways, Fox to Prudhoe Bay, Alaska,” 1983, by Jerry Brown and R.A. Kreig, editors, published by the Alaska Division of Geological \& Geophysical Surveys for the Fourth International Conference on Permafrost. \$15

\section{INFORMATION CIRCULARS}

IC 58. Alaska's mineral industry 2008: A summary, by Szumigala, D.J., Hughes, R.A., and Harbo, L.A., 2009, 15 p. Free

IC 59. Historically active volcanoes of Alaska reference deck, by Snedigar, S.F., and Cameron, C.C., 2009, 52 p.

IC 59 is a unique publication as it is in the format of playing cards. We think it's no coincidence that there 
are exactly 52 historically volcanoes in Alaska as of December 2009; and we hope to engage the user in a fun, educational experience. Each full-color card provides the location coordinates and photo of the volcano, and up to six colored dots that correspond to a legend on one of the joker cards. The dots represent characteristics of the volcano, such as a documented eruption, fumaroles, deformation, or earthquake swarms. The packet includes a two-sided information sheet with photo captions/credits for each volcano. \$6

\section{MISCELLANEOUS PUBLICATIONS}

MP 133. Historically active volcanoes of Alaska, by Schaefer, J.R., Cameron, C.E., and Nye, C.J., 2009, 1 sheet, scale 1:3,000,000. \$13

\section{NEWSLETTER (ALASKA GEOSURVEY NEWS)}

NL 2009-1. The Alaska Geologic Materials Center, by Reeder, J.W., 2009, 12 p. Free

\section{PRELIMINARY INTERPRETIVE REPORTS}

PIR 2009-3. A reconnaissance view of an unnamed fault near Capps Glacier, northwestern Cook Inlet basin, and its potential as a regional-scale, basin-controlling structure, by Gillis, R.J., LePain, D.L., Ridgway, K.D., and Finzel, E.S., 2009, 9 p. \$2

PIR 2009-4. Preliminary evaluation of basin margin exhumation and provenance of Cenozoic strata, Chuitna and Beluga rivers area, Cook Inlet forearc basin, Alaska, by Finzel, E.S., Gillis, R.J., Ridgway, K.D., and LePain, D.L., 2009, 16 p. \$2

PIR 2009-5. Geology of the Cobblestone Creek-May Creek area, east-central Brooks Range Foothills, Alaska, by Mull, C.G., Harris, E.E., Delaney, P.R., and Swenson, R.F., 2009, 40 p., 1 sheet, scale 1:63,360. $\$ 17$

PIR 2009-7. Geologic map of the Kanayut River area, Chandler Lake Quadrangle, Alaska, by Harris, E.E., Delaney, P.R., Mull, C.G., LePain, D.L., and Burns, P.C., 2009, 1 sheet, scale 1:63,360. \$13

PIR 2009-8. Preliminary results of recent geologic investigations in the Homer-Kachemak Bay area, Cook Inlet Basin: Progress during the 2006-2007 field season, by LePain, D.L., 2009, 187 p. \$19
PIR 2009-8A. Facies associations, sand body geometry, and depositional systems in Late OligocenePliocene Strata, southern Kenai Peninsula, Cook Inlet, Alaska: Report on progress during the 2006-07 field season, by LePain, D.L., Wartes, M.A., McCarthy, P.J., Stanley, R.G., Silliphant, L.J., Peterson, Shaun, Shellenbaum, D.P., Helmold, K.P., Decker, P.L., Mongrain, Jacob, and Gillis, R.J.

PIR 2009-8B. Sedimentology of an Oligocene-Miocene incised paleovalley, Tyonek Formation, Cook Inlet Basin, Alaska, by Finzel, E.S., Ridgway, K.D., and LePain, D.L.

PIR 2009-8C. Report on day trip (5/16/07) to visit Mesozoic rocks exposed in Port Graham and near Seldovia, southern Kenai Peninsula, by Blodgett, R.B.

PIR 2009-8D. Mercury injection capillary pressure results from outcrop samples in the Homer area of Cook Inlet, by Loveland, Andrea.

\section{RAW-DATA FILES}

RDF 2009-1. Geochemical, major-oxide, minor-oxide, trace-element and carbon data from rocks collected in 2008 in the eastern Bonnifield mining district, Fairbanks and Healy quadrangles, Alaska, by Freeman, L.K., Werdon, M.B., Szumigala, D.J., Andrew, J.E., Newberry, R.J., and Athey, J.E., 2009, 69 p. \$7

\section{REPORTS OF INVESTIGATIONS}

RI 2009-1. Sedimentology and sequence stratigraphy of the middle Albian-Cenomanian Nanushuk Formation in outcrop, Central North Slope, Alaska, by LePain, D.L., McCarthy, P.J., and Kirkham, Russell, 2009, 78 p., 1 sheet. $\$ 21$

RI 2009-2. Chert geochemistry discriminant analysis and K-means cluster analysis: Rampart project area, Tanana B-1 Quadrangle, east-central Alaska, by Reifenstuhl, R.R., Newberry, R.J., Haug, S.A., Clautice, K.H., Liss, S.A., and Weber, F.R., 2009, 16 p. \$2

RI 2009-3. Surficial-geologic map of the Kavik River area, west-central Mount Michelson Quadrangle, northeastern Brooks Range, Alaska, by Carson, E.C., 2009, 1 sheet, scale 1:63,360. \$13

\section{SPECIAL REPORTS}

SR 63. Alaska's mineral industry 2008, by Szumigala, D.J., Hughes, R.A., and Harbo, L.A., 2009, 89 p. Free 